\title{
APEC Energy Project
}

\section{Energy Efficiency and Conservation Theme}

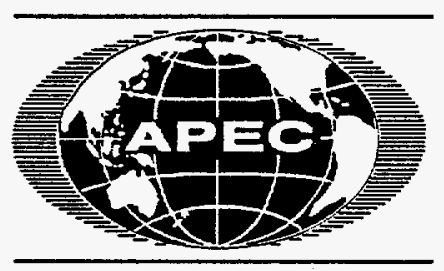

Compendium of Energy Efficiency and Conservation

Programs and Projects

in Asia Pacific Economic Cooperation (APEC)

Member Countries

Analytic Studies Division

National Renewable Energy Laboratory

Golden, CO 80401 USA 


\section{NOTICE}

This report was prepared as an account of work sponsored by an agency of the United States government. Neither the United States government nor any agency thereof, nor any of their employees, makes any warranty, express or implied, or assumes any legal liability or responsibility for the accuracy, completeness, or usefulness of any information, apparatus, product, or process disclosed, or represents that its use would not infringe privately owned rights. Reference herein to any specific commercial product, process, or service by trade name, trademark, manufacturer, or otherwise does not necessarily constitute or imply its endorsement, recommendation, or favoring by the United States government or any agency thereof. The views and opinions of authors expressed herein do not necessarily state or reflect those of the United States government or any agency thereof. 


\section{DISCLAIMER}

Portions of this document may be illegible in electronic image products. Images are produced from the best available original document. 


\section{Preface}

The Asia Pacific Economic Cooperation (APEC) agreement was initiated in 1989 at the ministerial level to promote the economic and social well-being of the APEC region. APEC member nations include Australia, Brunei, Canada, Chinese Taipei, Hong Kong, Indonesia, Japan, Korea, Malaysia, New Zealand, the Philippines, the People's Republic of China, Singapore, Thailand, and the United States.

APEC ministers identified six areas of cooperation:

1. Trade and investment data

2. Trade promotion

3. Expansion of investment and technology transfer

4. Human resource development

5. Marine resource conservation

6. Regional energy cooperation.

Four additional areas have been added:

1. Telecommunications

2. Fisheries

3. Transportation

4. Tourism.

Australia accepted the overall lead responsibility for the Regional Energy Cooperation area. At the first APEC Energy Officials Meeting, held in May 1990, it was decided that the Regional Energy Cooperation Project's objective would be to maximize the energy sector's contribution to the region's economic and social well-being by

- Contributing to decision making through frank and open discussions of national energy policies and planning priorities

- Sharing basic resource demand and supply outlook data

- Considering regional energy policy implications and responses to widereaching energy-related issues, such as the greenhouse effect.

A work program based on five main themes was also developed at this meeting, which has been endorsed by the APEC ministers. The theme areas are:

- Energy supply and demand

- Energy and environment

- Energy efficiency and conservation

- Research, development, and technology transfer

- Resource exploration and development.

The United States has accepted lead responsibility for the energy efficiency and conservation $(\mathrm{EE} \& \mathrm{C})$ theme.

As a result of the second meeting of the APEC energy officials, held in March 1991 in Jakarta, Indonesia, the United States, as part of the $\mathrm{EE} \& \mathrm{C}$ theme, agreed to publish a Compendium of Energy-Efficiency and Conservation Programs and Projects in APEC Member Countries. This document was to describe the major energy-efficiency and conservation programs/projects that have been undertaken or are being planned by each APEC country. The U.S. Department of Energy (DOE) has requested the National Renewable Energy Laboratory (NREL) to prepare this compendium.

Material was solicited from member countries and, in addition, information was gathered 
from various publications and periodicals. In September 1991, a draft document was circulated. Subsequently, additional information has been submitted by member countries, and some additional material was acquired during travel to the region by NREL and DOE personnel.

Based on the responses to the September 1991 draft and further information gathered by DOE and NREL, a second draft was prepared and distributed in association with the APEC Energy Efficiency and Conservation Theme Expert Group Meeting in October 1992.
The report briefly discusses the energy situation in each country, summarizes energyefficiency projects, and outlines the country's energy policy and strategy. The objective of this project was to determine the status of energy-efficiency activities in the 15 APEC countries. We hope that this report can be used to identify opportunities for regional coordination and cooperation.

The emphasis of this report is on simplicity of presentation. It provides quick access to basic information about the experiences of nations in the region, including sufficient information to facilitate country-to-country contact. 


\section{Table of Contents}

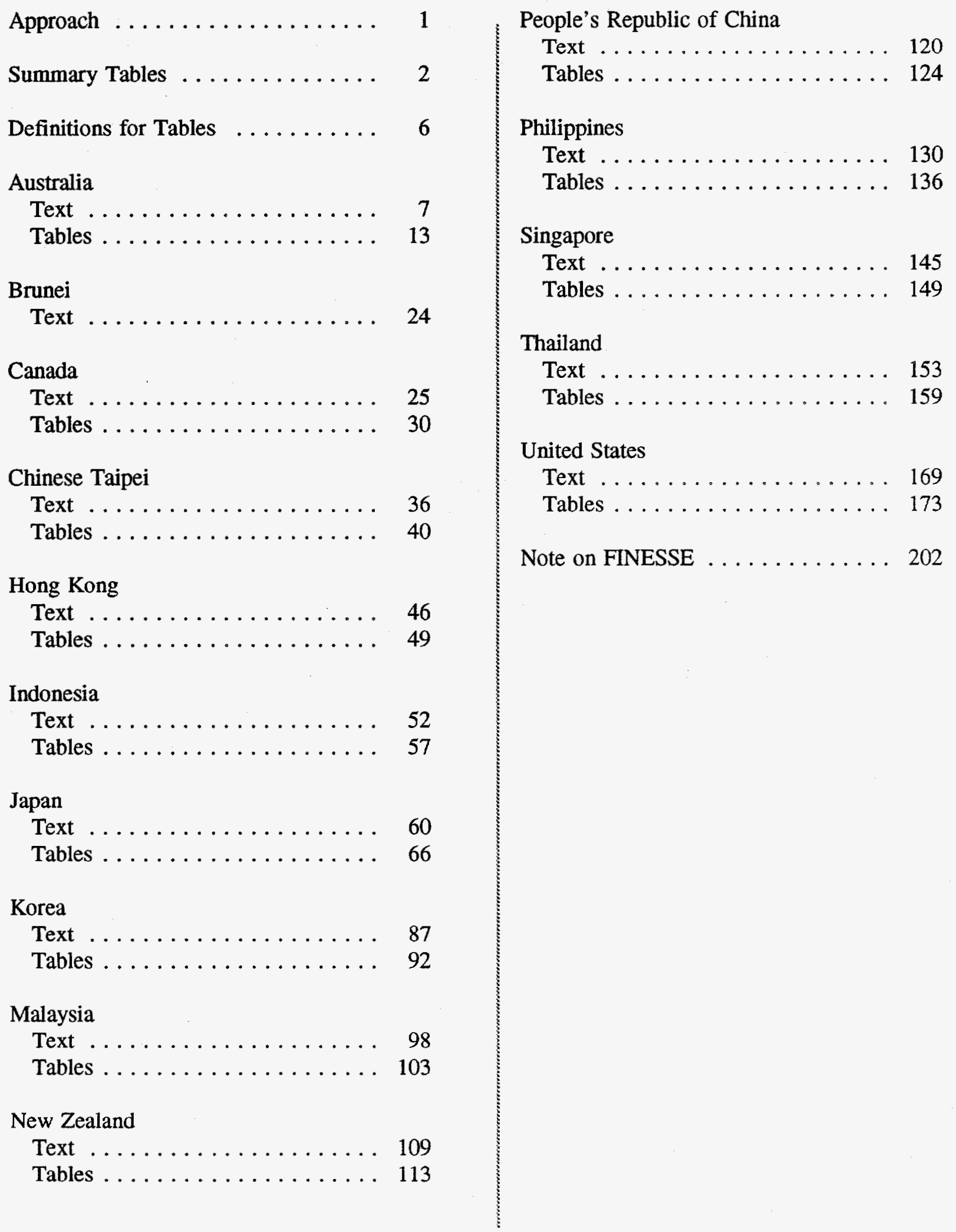




\section{Approach}

The information included in this report was collected from both primary and secondary sources. Primary sources were mainly official publications that were furnished by official contacts in each country. In addition, statistical data were taken from the World Bank's World Development Report. Secondary sources provided supplemental information on specific projects and, in some cases, more recent developments. These sources included newsletters, books, conference proceedings, etc.

Each chapter, covering one country, begins with a discussion that sets the context for the descriptions of energy-efficiency efforts. Energy use and policy issues are described, along with basic trade and economic information; a brief description of basic energy-efficiency programs and policies is included. Energy use and per capita energy consumption data are represented by million metric tons of oil equivalent (Mtoe) and kilograms of oil equivalent (kgoe), respectively. Following the text, a set of tables is presented. Each table includes specific information on energy-efficiency and conservation projects or programs. These tables are summarized in the summary tables that follow in this section.

The information in the tables was compiled for each project, then the tables were organized by end-use sector. Each table includes a brief overview of the project and the sponsoring organization, along with summary remarks about the economic and/or technical details. These tables are intended to give the reader sufficient information to efficiently identify projects that are of specific interest and to make contact with the appropriate organization. 


\begin{tabular}{|c|c|c|c|c|c|c|c|c|c|c|c|c|c|c|c|}
\hline \multicolumn{16}{|c|}{ APEC Country Profiles ${ }^{1}$} \\
\hline & Australia & Brunet $^{2}$ & Canada & $\begin{array}{c}\text { Chinese } \\
\text { Taipel }\end{array}$ & $\begin{array}{l}\text { Hong } \\
\text { Kong }\end{array}$ & Indonesia & Japan & Korea & Malaysia & $\begin{array}{c}\text { New } \\
\text { Zealand }\end{array}$ & $\begin{array}{l}\text { People's } \\
\text { Republic } \\
\text { of China }\end{array}$ & Phillppines & Singapore & Thalland & $\begin{array}{l}\text { United } \\
\text { States }\end{array}$ \\
\hline $\begin{array}{l}\text { Population } \\
\text { (millions) }\end{array}$ & 17 & - & 27 & 20 & 6 & 178 & 124 & 43 & 17 & 3 & 1,134 & 62 & 3 & 56 & 250 \\
\hline GDP (\$ mil) & 296,300 & - & 570,150 & 157,337 & $\begin{array}{l}82,731 \\
(1991) \\
\end{array}$ & 107,290 & $\begin{array}{c}3,373,824 \\
(1991) \\
\end{array}$ & 236,400 & 42,400 & 42,769 & 364,900 & 43,860 & 34,600 & 80,170 & $5,392,200$ \\
\hline Exports ( $\$$ mil) & 35,973 & - & 125,056 & $\begin{array}{l}84,280 \\
(1989)\end{array}$ & $\begin{array}{l}98,430 \\
(1991)\end{array}$ & 25,553 & $\begin{array}{l}314,525 \\
(1991)\end{array}$ & 64,837 & 29,409 & 9,045 & 62,091 & 8,681 & 52,627 & 28,881 & 371,466 \\
\hline Imports (\$ mil) & 39,740 & - & 115,882 & $\begin{array}{l}70,360 \\
(1989)\end{array}$ & $\begin{array}{l}100,507 \\
(1991)\end{array}$ & 21,837 & $\begin{array}{l}236,737 \\
(1991)\end{array}$ & 69,585 & 29,251 & 9,466 & 53,345 & 13,080 & 60,647 & 32,692 & 515,635 \\
\hline $\begin{array}{l}\text { Total primary } \\
\text { energy supply } \\
\text { (Mtoe) }\end{array}$ & 88.5 & 2.1 & 210 & 45.9 & 10 & 46.9 & 428 & 92.4 & 20.3 & 13.5 & 633 & 18.2 & 9.9 & 29.6 & 1,905 \\
\hline $\begin{array}{l}\text { Energy consump- } \\
\text { tion per capita } \\
\text { (kgoe) }\end{array}$ & 5,041 & - & 10,009 & $\begin{array}{l}2,641 \\
(1991)\end{array}$ & $\begin{array}{r}1,908 \\
(1991)\end{array}$ & 272 & 3,635 & 1,898 & 974 & 4,971 & 598 & 215 & 5,685 & 758 & 7,822 \\
\hline $\begin{array}{l}\text { Land area } \\
\text { (thousand } \mathrm{km}^{2} \text { ) }\end{array}$ & 7,687 & - & 9,976 & 36 & 1 & 1.9 & 378 & 99 & 332 & 269 & 9,561 & 300 & 1 & 515 & 9,373 \\
\hline
\end{tabular}

${ }^{1}$ All data, unless otherwise indicated, are based on the World Development Report 1992 for 1990.

${ }^{2}$ Data not available except for total primary energy supply.

${ }^{3}$ From International Energy Agency Statistics 1992 for 1990. 
Project Distribution by Type and Sector

\begin{tabular}{lcc} 
& Pumber & Percent \\
\hline R\&D & 87 & 31 \\
Study/demo & 115 & 41.5 \\
Audit & 9 & 3 \\
Survey & 4 & 1.5 \\
Standards and codes & 4 & 1.5 \\
Certification & 1 & 0.5 \\
Tech transfer & 6 & 2 \\
Education/info & 12 & 4 \\
Policy assessment & 39 & 14 \\
& & \\
Total & 277 & 99 \\
& & \\
& & \\
\multicolumn{1}{c}{ Sector } & Number & Percent \\
\hline Industry & 104 & 38 \\
Utility & 15 & 5 \\
Transportation & 20 & 7 \\
Residential building & 47 & 17 \\
Commercial building & 52 & 19 \\
Renewable energy & 20 & 7 \\
All sectors & 19 & 7 \\
& & 100 \\
Total & 277 & \\
& &
\end{tabular}


Summary Table (by country, end-use sector, and project type)

\begin{tabular}{|c|c|c|c|c|c|c|c|c|}
\hline & Industry & Utility & Transport & Res. bldg. & Cml. bldg. & $\begin{array}{c}\text { Renewable } \\
\text { energy }\end{array}$ & $\begin{array}{c}\text { All } \\
\text { sectors }\end{array}$ & Total \\
\hline $\begin{array}{l}\text { Australia } \\
\text { R\&D } \\
\text { Study/demo } \\
\text { Audit }\end{array}$ & $\begin{array}{l}2 \\
8 \\
1\end{array}$ & & 3 & $\begin{array}{l}1 \\
1\end{array}$ & & 4 & 1 & $\begin{array}{c}7 \\
13 \\
1\end{array}$ \\
\hline $\begin{array}{l}\text { Canada } \\
\text { R\&D } \\
\text { Study/demo } \\
\text { Policy Assess. }\end{array}$ & 1 & 1 & & $\begin{array}{l}3 \\
1\end{array}$ & $\begin{array}{l}1 \\
3\end{array}$ & 1 & 1 & $\begin{array}{l}7 \\
4 \\
1\end{array}$ \\
\hline $\begin{array}{l}\text { Chinese Taipei } \\
\text { R\&D } \\
\text { Study/demo } \\
\text { Standards and } \\
\text { codes } \\
\text { Policy assess. }\end{array}$ & 4 & & $\begin{array}{l}1 \\
1\end{array}$ & $\begin{array}{l}1 \\
1\end{array}$ & 2 & & 1 & $\begin{array}{l}1 \\
2 \\
2 \\
2 \\
8\end{array}$ \\
\hline $\begin{array}{l}\text { Hong Kong } \\
\text { R\&D } \\
\text { Policy assess. } \\
\text { Education/info }\end{array}$ & & & & & $\begin{array}{l}1 \\
3\end{array}$ & & 1 & $\begin{array}{l}1 \\
3 \\
1\end{array}$ \\
\hline $\begin{array}{l}\text { Indonesia } \\
\text { R\&D } \\
\text { Study/demo } \\
\text { Policy assess. } \\
\text { Audit }\end{array}$ & $\begin{array}{l}2 \\
1\end{array}$ & & & & 1 & 1 & & $\begin{array}{l}1 \\
1 \\
2 \\
2\end{array}$ \\
\hline $\begin{array}{l}\text { Japan } \\
\text { R\&D } \\
\text { Study/demo }\end{array}$ & $\begin{array}{c}5 \\
16 \\
\end{array}$ & $\begin{array}{l}3 \\
5 \\
\end{array}$ & 1 & 2 & 2 & $\begin{array}{l}6 \\
2 \\
\end{array}$ & 1 & $\begin{array}{l}18 \\
25\end{array}$ \\
\hline $\begin{array}{l}\text { Korea } \\
\text { R\&D } \\
\text { Study/demo } \\
\text { Policy assess. } \\
\text { Audit }\end{array}$ & $\begin{array}{l}4 \\
1 \\
3 \\
1\end{array}$ & 1 & & 2 & $\begin{array}{l}1 \\
1\end{array}$ & & & $\begin{array}{l}7 \\
2 \\
4 \\
1\end{array}$ \\
\hline $\begin{array}{l}\text { Malaysia } \\
\text { Study/demo } \\
\text { Audit } \\
\text { Survey } \\
\text { Education/info } \\
\text { Policy assess. }\end{array}$ & $\begin{array}{l}3 \\
3 \\
3 \\
1\end{array}$ & & & 1 & 1 & & 1 & $\begin{array}{l}4 \\
4 \\
4 \\
4 \\
1\end{array}$ \\
\hline
\end{tabular}




\begin{tabular}{|c|c|c|c|c|c|c|c|c|}
\hline & Industry & Utility & Transport & Res. bldg. & Cml. bldg. & $\begin{array}{c}\text { Renewable } \\
\text { energy }\end{array}$ & $\begin{array}{c}\text { All } \\
\text { sectors }\end{array}$ & Total \\
\hline $\begin{array}{l}\text { New Zealand } \\
\text { Study/demo } \\
\text { Policy assess. }\end{array}$ & $\begin{array}{l}2 \\
1\end{array}$ & & & $\begin{array}{l}2 \\
1\end{array}$ & $\begin{array}{c}12 \\
1\end{array}$ & & & $\begin{array}{l}16 \\
3\end{array}$ \\
\hline $\begin{array}{l}\text { People's Repub. } \\
\text { of China } \\
\text { Study/demo } \\
\text { Policy assess. }\end{array}$ & 7 & 1 & & $\begin{array}{l}1 \\
1\end{array}$ & 3 & & & $\begin{array}{l}12 \\
1\end{array}$ \\
\hline $\begin{array}{l}\text { Philippines } \\
\text { R\&D } \\
\text { Study/demo } \\
\text { Education/info } \\
\text { Policy assess. } \\
\text { Standards and } \\
\text { codes }\end{array}$ & $\begin{array}{l}1 \\
5 \\
2 \\
3\end{array}$ & & 1 & & $\begin{array}{l}1 \\
1 \\
1\end{array}$ & $\begin{array}{l}2 \\
1\end{array}$ & $\begin{array}{l}1 \\
3\end{array}$ & $\begin{array}{l}2 \\
8 \\
3 \\
8 \\
1\end{array}$ \\
\hline $\begin{array}{l}\text { Singapore } \\
\text { R\&D } \\
\text { Study/demo } \\
\text { Policy assess. }\end{array}$ & 1 & & 1 & & $\begin{array}{l}3 \\
1\end{array}$ & & 1 & $\begin{array}{l}4 \\
1 \\
2\end{array}$ \\
\hline $\begin{array}{l}\text { Thailand } \\
\text { R\&D } \\
\text { Study/demo } \\
\text { Audit } \\
\text { Education/info } \\
\text { Policy assess. }\end{array}$ & $\begin{array}{l}2 \\
4 \\
1 \\
1\end{array}$ & $\begin{array}{l}1 \\
2\end{array}$ & & 1 & & $\begin{array}{l}2 \\
1\end{array}$ & $\begin{array}{l}1 \\
1 \\
5\end{array}$ & $\begin{array}{l}6 \\
8 \\
1 \\
1 \\
6\end{array}$ \\
\hline $\begin{array}{l}\text { United States } \\
\text { R\&D } \\
\text { Study/demo } \\
\text { Standards and } \\
\text { codes } \\
\text { Certification } \\
\text { Tech transfer } \\
\text { Education/info }\end{array}$ & $\begin{array}{c}11 \\
4\end{array}$ & 1 & $\begin{array}{l}9 \\
3\end{array}$ & $\begin{array}{l}10 \\
7 \\
1 \\
1 \\
6 \\
3\end{array}$ & $\begin{array}{l}3 \\
4\end{array}$ & & & $\begin{array}{l}33 \\
19 \\
1 \\
1 \\
1 \\
6 \\
3\end{array}$ \\
\hline
\end{tabular}




\section{Definitions for Tables}

The tables that follow each country section include the following information:

- Title-The title gives the exact title of the project or the general aim of the project.

- Organization-The organization section describes the government branch, corporation, trade group, or energy administration, research institution, etc.

- End-use Sector-The end-use sector section classifies the project's application as industry, utility, transportation, residential building, commercial building, renewable energy, other (multisector), or all sectors.

- Description-The description section reports the intent of the project, the background of the project, and a general overview of the project.

- Results-The results section gives a synopsis of the results or current status of the project.

- Project Type-The project type section classifies the project as research and development; study/demonstration; audit; survey; standards and codes; certification; technology transfer; education/information; and policy assessment.

- Date-This section cites the starting and ending dates of the project or classifies the project as ongoing.

- Affiliated Projects-This section describes any past or future projects that are connected to the entry.

- Technology-This section describes the technology or combination of technologies used for the project.

- Reference-A short bibliographical entry. 


\section{Australia}

Australia is an island continent about the size of the continental United States. There are 17 million people of European and Asian heritage. More than $60 \%$ of the population lives in urban settings.

The Australian government is a parliamentary democracy, and a prime minister acts as the head of state.

Australia relies heavily on its natural resources for economic prosperity. With the recent downturn in commodity prices, Australia has been thrown into an extended recession. This slow economic growth has been accompanied by high interest rates, low consumer confidence, and rapidly rising unemployment. Recently, gross national product growth has been below 3\%; the average rate of inflation was $7.4 \%$ from 1980 through 1990 .

Australian gross domestic product (GDP) reached US $\$ 296,300$ million in 1990 , up from US $\$ 24,220$ million in 1965. This represents an average annual growth rate of $1.9 \%$. The GDP came from the following market sectors: agriculture (4\%), industry (31\%), and services (64\%); within industry, manufacturing comprised $15 \%$ of the GDP. The GDP rose $1.4 \%$ in 1990 . A GDP growth of $2.2 \%$ was predicted for 1991 .

For the period of 1980 to 1990 , interest rates averaged 12.8\%. After peaking in 1989, the rates fell during 1990 and 1991. The value of building approved for 1990 was $16.5 \%$ lower than in 1989; registrations of new vehicles decreased $21 \%$.

In 1990 , exports totaled US $\$ 35,973$ million and imports totaled US\$39,740 million. Over the period 1980 to 1990 , the average annual growth rate for exports was $3.9 \%$, and the average annual growth rate for imports was $4.7 \%$.

For 1992, the Pacific Economic Outlook predicts Australia will enjoy stronger GDP growth than in 1991. Domestic-expenditure growth is likely to rise, but the trade accounts are expected to weaken. Inflation is likely to increase, and there will be little change in the unemployment rate.

\section{Energy Use and Policy Issues}

In 1989, total energy use in Australia totaled 97.1 million tons of oil equivalent (Mtoe). Australia is a net energy exporter. By the year 2000, this is expected to grow to $107.3 \mathrm{Mtoe}$.

Australia has vast reserves of coal, Bass Strait crude oil, natural gas, and hydroelectric potential. Energy use by fuel type is: coal $40 \%$, petroleum $37 \%$, natural gas $17 \%$, and renewables $6 \%$. While Australia is a net energy exporter, it imports some oil and is concerned with the effects of disruptions in oil supply.

Per capita energy consumption equaled 5,041 kilograms of oil equivalent (kgoe) in 1990, up from 3,287 kgoe in 1965 . For the period of 1980 to 1990 , energy consumption grew at an annual rate of $2.2 \%$. For the years between 1965 and 1980, energy consumption grew at an annual rate of 5\%.

The transportation end-use sector accounts for the largest consumption of energy, using $38 \%$ of the final energy supply. Other sector uses include manufacturing (34\%), residential (12\%), agriculture and mining $(8 \%)$, commercial $(6 \%)$, and other $(2 \%)$. 
Electricity is about $18 \%$ of final energy demand in Australia. Most of this electricity is generated using coal-fired steam turbines. The Department of Primary Industries forecasts electricity growth to increase $2 \%$ to $3.8 \%$ for the period 1988 to 2000 .

Australia is a major producer of uranium and is involved with the front-end cycle of transforming uranium into yellow cake. There are no nuclear power plants in Australia, and the country has no plans to construct them.

\section{Policies, Plans, and Projections}

The energy objectives for the 1990 s are

- To produce and use energy efficiently

- To improve the environment.

The energy policies for the 1990 s are

- To ensure that prices reflect social values of energy production and use in the freely working markets

- To provide full information about efficient technology, practices, and alternatives

- To support R\&D in energy efficiency and renewable energy.

Australia also participates in international cooperation projects with the Association of Southeast Asian Nations (ASEAN), Japan, the United States, and other countries.

Ecologically sustainable development is a long-range issue in Australia, and the government is committed to the following goals:

- Minimize or avoid the harmful environmental consequences of energy production and use.

- Establish access to resources that meet economic needs but do not jeopardize the environment.

- $\quad$ Price energy resources to reflect their true value and the full costs of production.

- Enable consumers to make rational decisions about energy use.

- Promote institutional arrangements for the energy supply industries.

- Ensure that energy R\&D and information dissemination focus on energy efficiency and new and improved technologies. 
- $\quad$ Recognize the place of energy security considerations.

- Support Australia's obligations as a global energy supplier.

\section{Alternative Fuels}

Indigenous production of crude oil and condensate is currently $85 \%$ of needs and is estimated to remain at about the current level, on average, over the period 2004 to 2005.

Liquefied petroleum gas (LPG) is an established transport fuel in Australia, having sales that are approximately $2.3 \%$ that of gasoline. It is typically used by fleet vehicles. Currently, the government does not place a tax on LPG, and it retails for about half the price of gasoline. In most applications, conversion from gas to LPG costs about $\mathrm{A} \$ 1,800$ and can be paid back in only a few months. Annual growth of LPG use should be around 3\% and should eventually reach 7\% of gasoline sales.

The government is supporting the use of natural gas in the transport sector. The benefits of natural gas include reduced emissions of particulate matter and carbon dioxide. Although the economics of natural gas appears attractive in some markets, the most likely use for a natural gas vehicle in Australia will be as a replacement for diesel engines. In some states, natural gas is already being trial tested in urban bus fleets, and the use of natural gas in heavy vehicles appears to be an attractive proposition in many applications.

The largest-scale development activity for alternative fuels was the conversion of Australian brown coal into liquid fuels. The governments of Japan and Australia and the state government of Victoria cooperated on the A $\$ 400$ million project, which was funded by Japan. This synthetic fuels project provided valuable information on brown coal liquefaction and will be the technological foundation of any future synfuels industry for Japan or Australia.

\section{Energy Efficiency and Conservation}

The barriers to energy-efficiency improvements in Australia may be summarized as follows:

- There are distortions in the energy marketplace; prices do not fully reflect all costs of production and use, including environmental impacts. Energy-efficiency equipment is not appropriately valued.

- In the transportation sector, low excise taxes on petroleum are an impediment to greater efficiency. Taxes, exemptions, and fees on various fuels and equipment do not reflect their energy content, efficiency of use, or pollutants.

- Consumers favor equipment with lower capital cost. Other problems related to energy consumers include

- Lack of useful data and information on options

- Limited access to investment capital for improving energy efficiency

- Lack of understanding of new energy-efficient technologies; insufficient training

- Poor accounting of energy costs, such as when electricity costs are included in a lease and the lessor cannot track costs. 
Australia has a federal system of government, and responsibility for energy and energy efficiency is shared between the state/territory and national levels of government. While each state and territory government is autonomous in its own sphere of responsibility, the national government provides a base level of energy conservation and efficiency services nationwide. An established framework exists at the ministerial level for consultation and project cooperation among the governments. Working parties of officials and experts support this framework when needed.

At the national level, current energy management program initiatives comprise the following:

- Technology transfer: Center for the Analysis and Dissemination of Demonstrated Energy Technologies, with a series of national- and state-based government/private sector communications networks; a technology demonstration program, with particular emphasis on buildings; national energy awards; publication of Australian Energy Management News; a model integrated energy management advisory center for households and businesses; and information exchange between commonwealth and state governments

- $\quad$ Residential community: Information kit, including The Energy Guide; appliance energy-labeling program; a national appliance energy-efficiency data center; development of minimum energy-efficiency standards for domestic appliances; promotion of energy-efficient housing design and urban planning; development of a Home Energy Rating Scheme for new houses; development of national minimum energy-efficiency standards for new residential construction; local community energyefficiency campaigns

- Industry and commerce: Financial support for energy audits in industrial, commercial, and institutional enterprises; energy management seminar/workshop support, currently being extended to in-house energy management training support; sector energy use and efficiency improvement studies; an energy extension officer program; development of national minimum energy-efficiency standards for new commercial construction; energy management advisory literature

- Transportation: National Average Fuel Consumption Program (in cooperation with industry); fuel consumption guides for passenger and light commercial vehicles; advisory materials and training programs in fleet management; analyses of further policy instruments (taxation systems, mandatory fuel consumption advertising and labeling programs, etc.)

- Energy management in government: Nomination of energy managers in government units; annual reporting of energy use and improvement in government buildings, housing, and leased facilities; energy audit of government vehicle fleets; assessment of alternative fuels; program exchange with other tiers of government.

Each state and territory government has a similar range of complementary initiatives, depending on local needs and priorities. Development of labeling programs, minimum energy-efficiency standards for appliances and buildings, and some broad communications programs are multigovernment cooperative ventures.

Energy utilities in all states are either assessing or have embarked on demand-side management/leastcost planning programs. There is a wide range of services encompassed by these programs, covering 
advisory, research, demonstration, and financial support initiatives in all sectors of the economy. Most utilities also provide extensive energy management services on a fee-for-service basis.

From 1978 to 1989 , the Australian government supported renewable energy research through the National Energy Research Development and Demonstration Program (NERD\&D). It provided nearly A $\$ 33$ million for research projects, including associated technologies such as energy storage.

The objective of the NERD\&D program was to stimulate energy R\&D and to help develop technologies for market applications. The program identified promising areas of research through workshops, studies, and reviews and directed support towards technologies "with the best chances of achieving commercial successes."

In 1990, the Australian government established the Energy Research and Development Corporation to administer publicly funded support for noncoal energy R\&D. This action intends "to make Australian energy R\&D more responsive to the needs of industry and to provide greater flexibility for government programs." Since October 1990 , the corporation has committed A $\$ 4.9$ million to renewable energy $R \& D$ projects.

Universities in Australia, including the University of New South Wales (UNSW) and Sydney University, actively research renewable energy. UNSW researchers developed the highest efficiency photovoltaics from commercial silicon. Sydney University researchers developed evacuated glazing materials having excellent insulation properties for windows. Other universities actively involved in solar energy research include Murdoch University, University of Melbourne, and University of Queensland.

In addition to the commonwealth programs, several states support renewable energy programs. Renewables make a modest but valuable contribution to the overall energy supply in Australia. The renewable energy industry contributes more than $A \$ 100$ million in yearly sales to the Australian economy. It is estimated that $6 \%$ of all Australian homes use solar water heating and that in some areas up to $37 \%$ of homes use this technology. Photovoltaics and solar-heated swimming pools also represent large markets for renewable energy technologies.

In short, the government's energy policy can be succinctly summarized as follows:

- A national approach to energy policy to remove differences between states and the national objectives (i.e., taxes, resources, royalties, environmental regulations, and pricing)

- Accounting for environmental costs (The government wants to determine how to value and promote environmentally friendly energy technologies, including renewables.)

- Increased energy efficiency by removing distortions in pricing, improving energy management, developing national energy standards, and undertaking energy $R \& D$

- Reform of electricity supply industry, including more use of renewables

- A national strategy for natural gas

- A secure energy future

- Expansion of Australia's energy trade. 


\section{Bibliography}

An Overview of Energy Research, Development and Demonstration in Australia, 14th Congress of the World Energy Conference; September 1989

APEC-Energy Efficiency and Conservation Theme; Bob Alderson; December 1991

Australian Approaches to the Production of Alternative Fuels, 14th Congress of the World Energy Conference; September 1989

Clean and Safe Energy Forever, Volume 2, Proceedings of the 1989 Congress of the International Solar Energy Society; September 1989

Compendium of Australian Energy Research and Development and Demonstration Projects, 1989

Energy and the Greenhouse Effect, 1990

Energy 2000: A National Energy Policy Paper; Department of Primary Industries and Energy; 1988

Energy and Environment; Response to Community Survey

Energy and Road Transport, 1990

Energy Research Programs in Australia, 1989

Fueling the 21st Century, New York: Hemisphere Publishing, 1989

Global Climatic Change, Issues for Australia, 1989

Issues in Energy Policy: An Agenda for the 1990s; Department of Primary Industries and Energy; June 1991

Launch of the Energy Guide; Louise Sylvan, Australian Consumers' Association

National Energy Management; Alan Griffiths, Minister for Resources; October 1990

Renewable Energy, EPD Discussion Paper No. 3, Energy Programs Division, Department of Primary Industries and Energy; I.J. Walker and M.R. Stevens; November 1990

The Role of Alternative Fuels and Conservation in Australia's Energy Future, 14th Congress of the World Energy Conference; September 1989

The Energy Guide; Australian Government and Australian Consumers' Association

Working Papers:

Energy Efficiency Measures to Reduce Environmental Impact

Energy Efficiency Program

A National Strategy for the Natural Gas Industry 


\begin{tabular}{|c|c|}
\hline $\begin{array}{l}\text { Title: Solar Industrial Process Steam } \\
\text { Demonstration Plant }\end{array}$ & Project Type: Study/demonstration \\
\hline $\begin{array}{l}\text { Organization: University of New South Wales } \\
\text { (School of Mechanical Engineering) }\end{array}$ & Date: 1988 \\
\hline End-use Sector: Industry & Affiliated/Future Projects: None \\
\hline $\begin{array}{l}\text { Description: Study/demonstration of a solar } \\
\text { industrial steam system }\end{array}$ & $\begin{array}{l}\text { Technology: A pilot system to measure } \\
\text { performance, uncover design programs, and test } \\
\text { integration with conventional boilers }\end{array}$ \\
\hline $\begin{array}{l}\text { Results: Development of actual system was } \\
\text { riddled with problems concerning data collection } \\
\text { and steel corrosion. Refinements are in } \\
\text { development. }\end{array}$ & Reference: Clean and Safe Energy Forever \\
\hline
\end{tabular}

\begin{tabular}{|c|c|}
\hline $\begin{array}{l}\text { Title: Energy Use in the Plastics and Rubber } \\
\text { Industry }\end{array}$ & Project Type: Study/demo; tech transfer \\
\hline Organization: Enman Pty. Ltd., through DPIE & $\begin{array}{l}\text { Date: Study completed December } 1991 \text {; } \\
\text { technology transfer phase to begin early } 1992\end{array}$ \\
\hline End-use Sector: Industry & Affiliated/Future Projects: None \\
\hline $\begin{array}{l}\text { Description: An analysis of the type, extent } \\
\text { and patterns of energy use in enterprises } \\
\text { employing powder metals technologies; an } \\
\text { analysis of the options for improving energy } \\
\text { efficiency and the cost-effectiveness of those } \\
\text { options }\end{array}$ & $\begin{array}{l}\text { Technology: Compressed air systems, steam } \\
\text { reticulation and use, process heating and } \\
\text { cooling, extrusion systems, general energy } \\
\text { management improvement }\end{array}$ \\
\hline $\begin{array}{l}\text { Results: Potential energy savings of almost } \\
20 \% \text { were identified, arising mainly from the } \\
\text { upgrading of technology applications. }\end{array}$ & Reference: DPIE \\
\hline
\end{tabular}




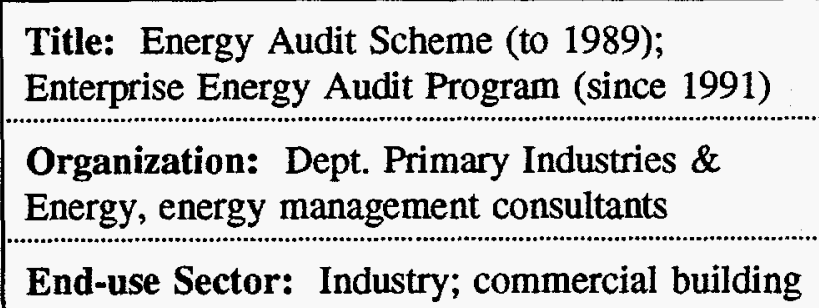

Description: Initial program provided financial support for small-scale walk-through energy audits of industrial and commercial enterprises (up to $50 \%$ of cost to a set limit of $\$ 300$ per audit). New program provides similar service for more detailed audits, with a $\$ 5,000$-per-audit limit on government contribution.

Results: Ratio of savings to audit costs averaged 20:1 for walk-through audits across all industries. Given nature of audits, most savings were low-cost, energy management options. Insufficient data were available from results of new program, but substantially greater savings/outlay ratios have been achieved so far.
Project Type: Audit; study/demo

Date: $1980-81$ to $1988-89$

Affiliated/Future Projects: Energy management seminar/workshop support program

Technology: Full range of process and control technologies covered

Reference: DPIE
Title: Improving Energy Use in the Australian Textile Industry

Organization: Energetics Pty. Ltd. (through NERD\&D Program)

End-use Sector: Industry (textiles, clothing, and footwear)

Description: An analysis of the type, extent, and patterns of energy use in the textile industry sector; an analysis of the options for improving energy efficiency and the cost-effectiveness of those options

Results: Potential energy savings of over 20\% in the wet processing operations of textile manufacture; $10 \%$ savings in other areas. Some firms have achieved savings of $30 \%$ and more.
Project Type: Study/demo; tech transfer

Date: August 1986 to August 1987

Affiliated/Future Projects: Dyehouse vessel insulation (a demonstration project arising from the study)

Technology: Textile stenters and dryers, wet processing technologies and dyehouse heat recovery, wool scouring and drying, carpet printing and drying, continuous drying plant

Reference: National Energy Research, Development and Demonstration Program (contact per DPIE) 
Title: A Study of Energy Use and Potential for Improved Energy Efficiency in the Australian Foundry Industry

Organization: Gas \& Fuel Corporation of Victoria (through NERD\&D Program)

End-use Sector: Industry (basic metals subsector)

Description: An analysis of the type, extent, and patterns of energy use in the foundry industry sector; an analysis of the options for improving energy efficiency and the costeffectiveness of those options

Results: A range of energy-efficiency improvement options were identified; overall, potential for energy-efficiency improvement was nearly $10 \%$, based on better management and investments with an average payback of 15 months. A need for further demonstration work, particularly on ladle preheating, was identified (and subsequently undertaken).
Project Type: Study/demo; tech transfer

Date: June 1986 to February 1988

Affiliated/Future Projects:

Technology: Heat recovery, process control, combustion technologies and management systems, general energy management of operations

Reference: National Energy Research, Development \& Demonstration Program (contact per DPIE)
Title: Energy Use and Potential for Increased Energy Efficiency in the Australian Diecasting Industry

Organization: Merz Australia Ltd.

End-use Sector: Industry (basic metals subsector)

Description: An analysis of the type, extent, and patterns of energy use in the diecasting industry sector; an analysis of the options for improving energy efficiency and the costeffectiveness of those options

Results: A range of energy-efficiency improvement options were identified; overall, energyefficiency improvement potential is approximately $25 \%$ through short-term measures, having the potential for an additional $25 \%$ if maximum technology upgrade options are exercised.
Project Type: Study/demo; tech transfer

Date: Study completed December 1990; technology transfer continues

Affiliated/Future Projects: Powder metals industry study

Technology: Heat recovery, process control, furnace burner control and management systems, compressed air systems, general energy management of operations

\section{Reference: DPIE}




\begin{tabular}{|c|c|}
\hline $\begin{array}{l}\text { Title: A Study of Energy Use in Basic Metals } \\
\text { Industries Using Powder Metal Technologies }\end{array}$ & Project Type: Study/demo; tech transfer \\
\hline Organization: Merz Australia Ltd. & $\begin{array}{l}\text { Date: Study completed December } 1990 \text {; } \\
\text { technology transfer continues }\end{array}$ \\
\hline $\begin{array}{l}\text { End-use Sector: Industry (basic metals } \\
\text { subsector) }\end{array}$ & $\begin{array}{l}\text { Affiliated/Future Projects: Diecasting industry } \\
\text { study }\end{array}$ \\
\hline $\begin{array}{l}\text { Description: An analysis of the type, extent, } \\
\text { and patterns of energy use in enterprises } \\
\text { employing powder metals technologies; an } \\
\text { analysis of the options for improving energy } \\
\text { efficiency and the cost-effectiveness of those } \\
\text { options }\end{array}$ & $\begin{array}{l}\text { Technology: Furnace control, sintering } \\
\text { mediums and processes, waste heat recovery, } \\
\text { RBO zone development, press design }\end{array}$ \\
\hline $\begin{array}{l}\text { Results: Potential short-term energy-efficiency } \\
\text { improvements of } 25 \% \text { were identified; an } \\
\text { additional } 25 \% \text { potential savings is possible if } \\
\text { all technology upgrade options are exercised. }\end{array}$ & $\begin{array}{l}\text { Reference: National Energy Research, } \\
\text { Development \& Demonstration Program } \\
\text { (contact per DPIE) }\end{array}$ \\
\hline
\end{tabular}

\begin{tabular}{|c|c|}
\hline $\begin{array}{l}\text { Title: Four Projects Demonstrating Energy- } \\
\text { Efficiency Improvement Potential in Furnace } \\
\text { Operation }\end{array}$ & Project Type: R\&D; tech transfer \\
\hline $\begin{array}{l}\text { Organization: Gas \& Fuel Corporation of } \\
\text { Victoria (2); Energetics Pty. Ltd. (2) }\end{array}$ & Date: 1987 to 1988 \\
\hline $\begin{array}{l}\text { End-use Sector: Industry (basic metals, metal } \\
\text { products) }\end{array}$ & Affiliated/Future Projects: None \\
\hline $\begin{array}{l}\text { Description: Projects covered four areas of } \\
\text { high-temperature process heating: nonferrous } \\
\text { metal extrusions; fastener manufacture; } \\
\text { aluminum remelt facilities, and ferrous piece- } \\
\text { work production. The task was to identify } \\
\text { options to improve efficiency through burner } \\
\text { control, better heat treatment, and heat recovery. }\end{array}$ & $\begin{array}{l}\text { Technology: The four technologies were (1) a } \\
\text { radiation-type waste heat recuperator for a high- } \\
\text { temperature furnace in corrosive environment, } \\
\text { (b) self-recuperative burners for radiant tube } \\
\text { fired furnace, (3) regenerative burners in an } \\
\text { aluminum remelt operation, (4) rapid fired } \\
\text { heater for metal piecework. }\end{array}$ \\
\hline $\begin{array}{l}\text { Results: All projects demonstrated substantial } \\
\text { efficiency improvements, having an average } \\
\text { payback on investments of less than } 2 \text { years. } \\
\text { The self-recuperative burners in the fastener } \\
\text { manufacturing plant had only modest returns on } \\
\text { energy grounds but also allowed a } 17 \% \\
\text { productivity improvement, reducing payback of } \\
\text { the } \$ 72,000 \text { investment to } 2.1 \text { months. }\end{array}$ & Reference: DPIE \\
\hline
\end{tabular}




\begin{tabular}{|c|c|}
\hline $\begin{array}{l}\text { Title: Solar Powered Electrical Services for } \\
\text { Remote Aboriginal Homeland Settlements }\end{array}$ & Project Type: R\&D \\
\hline $\begin{array}{l}\text { Organization: Solar Energy Research Institute } \\
\text { of WA, Murdoch University (through NERD\&D } \\
\text { Program) }\end{array}$ & Date: January 1986 to March 1988 \\
\hline $\begin{array}{l}\text { End-use Sector: Renewable energy; residential } \\
\text { building }\end{array}$ & Affiliated/Future Projects: None \\
\hline $\begin{array}{l}\text { Description: Development of a photovoltaic- } \\
\text { based power supply system for integration into } \\
\text { transportable housing systems and settlements to } \\
\text { provide water pumping, radio communications, } \\
\text { lighting, refrigeration and cooling for remote, } \\
\text { arid and tropical settlements }\end{array}$ & $\begin{array}{l}\text { Technology: Transportable photovoltaic power } \\
\text { units and associated electrotechnology }\end{array}$ \\
\hline $\begin{array}{l}\text { Results: Systems were established and high } \\
\text { levels of reliability and performance were } \\
\text { demonstrated. }\end{array}$ & Reference: NERD\&D Program/DPIE \\
\hline
\end{tabular}

\begin{tabular}{|c|c|}
\hline $\begin{array}{l}\text { Title: Reducing Ferrous Melting Costs with } \\
\text { Assisted Melting of Preheating }\end{array}$ & Project Type: R\&D; study/demo \\
\hline $\begin{array}{l}\text { Organization: Metal Trades Industry } \\
\text { Association/Gas and Fuel Corporation of } \\
\text { Victoria }\end{array}$ & Date: Completed December 1988 \\
\hline End-use Sector: Industry (basic metals) & $\begin{array}{l}\text { Affiliated/Future Projects: Foundry industry } \\
\text { study }\end{array}$ \\
\hline $\begin{array}{l}\text { Description: Project designed to evaluate the } \\
\text { extent of further potential efficiency gains in } \\
\text { foundry operations, consequent upon a study of } \\
\text { energy-efficiency improvement opportunities in } \\
\text { that sector }\end{array}$ & $\begin{array}{l}\text { Technology: Preheat technologies, particularly } \\
\text { charge bucket preheaters and vibratory bed } \\
\text { preheaters }\end{array}$ \\
\hline $\begin{array}{l}\text { Results: The effectiveness and efficiency of the } \\
\text { technology is highly sensitive to type and } \\
\text { structure of foundry operations. However, } \\
\text { potential for improvement in foundry furnace } \\
\text { productivity of up to } 18 \% \text { was identified. }\end{array}$ & Reference: NERD\&D Program/DPIE \\
\hline
\end{tabular}




\begin{tabular}{|c|c|}
\hline $\begin{array}{l}\text { Title: Potential for Gantry Systems in } \\
\text { Australian Agriculture }\end{array}$ & Project Type: Study/demonstration \\
\hline $\begin{array}{l}\text { Organization: Darling Downs Institute of } \\
\text { Advanced Education/NERD\&D Program }\end{array}$ & Date: 1985 to 1987 \\
\hline $\begin{array}{l}\text { End-use Sector: Industry (agriculture, } \\
\text { horticultural crops) }\end{array}$ & Affiliated/Future Projects: None \\
\hline $\begin{array}{l}\text { Description: Gantry harvesting had had limited } \\
\text { application in Australia. The purpose of the } \\
\text { study was to evaluate the potential of gantry } \\
\text { harvesting for use in cropping a wider range of } \\
\text { vegetables and lucerne. }\end{array}$ & $\begin{array}{l}\text { Technology: Alternative gantry systems and } \\
\text { operating techniques }\end{array}$ \\
\hline $\begin{array}{l}\text { Results: Modeled gains were seen in } \\
\text { productivity: } 5 \% \text { increase in yield; reduced } \\
\text { tillage requirements; } 10 \% \text { reduction in picking } \\
\text { costs; reduced levels of soil impaction. Energy } \\
\text { savings of } 50 \% \text { were realized, principally due to } \\
\text { reduced tillage requirements }\end{array}$ & $\begin{array}{l}\text { Reference: National Energy Research, } \\
\text { Development \& Demonstration Program/DPIE }\end{array}$ \\
\hline
\end{tabular}

\begin{tabular}{|c|c|}
\hline $\begin{array}{l}\text { Title: Energy Management in the Brick } \\
\text { Industry }\end{array}$ & Project Type: Study/demonstration \\
\hline $\begin{array}{l}\text { Organization: NSW Department of } \\
\text { Energy/NERD\&D Program }\end{array}$ & Date: June 1986 \\
\hline End-use Sector: Industry (bricks and ceramics) & Affiliated/Future Projects: None \\
\hline $\begin{array}{l}\text { Description: An analysis of the type, pattern, } \\
\text { and efficiency of energy use in brickmaking, } \\
\text { and an analysis of the potential for further } \\
\text { energy-efficiency improvements }\end{array}$ & $\begin{array}{l}\text { Technology: In tunnel kilns, insulation of kiln } \\
\text { cars; effective stack penetration by flames and } \\
\text { hot gases; heat extraction from fired bricks; gas } \\
\text { circulation in preheater. In intermittent kilns, } \\
\text { separate dryers using heat recovered from fired } \\
\text { bricks; shortened cycle times. }\end{array}$ \\
\hline $\begin{array}{l}\text { Results: Savings from basic housekeeping and } \\
\text { modest investment would allow energy savings } \\
\text { of more than } 10 \% \text {. A specific fuel consumption } \\
\text { of } 10 \text { gigajoules per } 1000 \text { units represents a } \\
\text { reasonable performance target but would require } \\
\text { more substantial investment by a number of } \\
\text { enterprises. }\end{array}$ & $\begin{array}{l}\text { Reference: National Energy Research, } \\
\text { Development \& Demonstration Program/DPIE }\end{array}$ \\
\hline
\end{tabular}




\begin{tabular}{|l|l|}
\hline Title: LPG-powered Buses & Project Type: Study/demonstration \\
\hdashline Organization: Transperth & Date: Commenced early 1980s; continuing \\
\hdashline End-use Sector: Transportation (urban) & $\begin{array}{l}\text { Affiliated/Future Projects: Natural gas-fueled } \\
\text { urban buses }\end{array}$ \\
\hdashline $\begin{array}{l}\text { Description: Use of LPG as a fuel for urban } \\
\text { bus fleets in Perth. }\end{array}$ & $\begin{array}{l}\text { Technology: Buses with commercially } \\
\text { available spark ignition engines designed to } \\
\text { operate on LPG }\end{array}$ \\
\hdashline $\begin{array}{l}\text { Results: Transperth has operated its LPG } \\
\text { fueled city buses for around 10 years and has } \\
\text { accumulated over 1 million kilometers of } \\
\text { operating experience with them. }\end{array}$ & Reference: DPIE \\
\hline
\end{tabular}

\begin{tabular}{|l|l|}
\hline Title: Natural-gas-powered Trucks & Project Type: Study/demonstration \\
\hdashline $\begin{array}{l}\text { Organization: Gas and Fuel Corporation of } \\
\text { Victoria, AGL Sydney Pty Ltd., Gaspower } \\
\text { Technology Australia Pty Ltd., International } \\
\text { Harvester Australia Ltd., Ford Motor Company } \\
\text { of Australia Ltd. }\end{array}$ & Date: Commenced 1988; continuing \\
\hdashline End-use Sector: Transportation (road) & \\
\hdashline $\begin{array}{l}\text { Description: Development of natural gas } \\
\text { engines and their demonstration in urban and, } \\
\text { more recently, line haul trucks. }\end{array}$ & \\
\hdashline $\begin{array}{l}\text { Results: Electronically controlled systems have } \\
\text { been developed that maximize the substitution } \\
\text { of gas for diesel in a dual fuel engine. }\end{array}$ & Technology: Spark-ignition and dual fuel \\
\hline
\end{tabular}




\begin{tabular}{|c|c|}
\hline Title: Natural-gas-powered Buses & Project Type: Study/demonstration \\
\hline $\begin{array}{l}\text { Organization: Transperth, Gas and Fuel } \\
\text { Corporation of Victoria, Brisbane City Council, } \\
\text { New South Wales State Transit Authority, South } \\
\text { Australian State Transport Authority, Benders } \\
\text { Busways }\end{array}$ & Date: Commenced 1988; continuing \\
\hline End-use Sector: Transportation (urban) & $\begin{array}{l}\text { Affiliated/Future Projects: Natural-gas-fueled } \\
\text { trucks }\end{array}$ \\
\hline $\begin{array}{l}\text { Description: Trials in the use of natural gas as } \\
\text { a fuel for urban bus fleets in major Australian } \\
\text { cities. }\end{array}$ & $\begin{array}{l}\text { Technology: Buses with commercially avail- } \\
\text { able spark-ignition engines designed to operate } \\
\text { on natural gas; refueling systems and } \\
\text { lightweight gas cylinders }\end{array}$ \\
\hline $\begin{array}{l}\text { Results: The first of these trials was conducted } \\
\text { in Perth, where three buses have accumulated } \\
\text { some } 250,000 \text { kilometers. }\end{array}$ & $\begin{array}{l}\text { Reference: National Energy Research, } \\
\text { Development and Demonstration Program/DPIE }\end{array}$ \\
\hline
\end{tabular}

\begin{tabular}{|c|c|}
\hline Title: Five-star Design Rating for New Homes & Project Type: R\&D; study/demo \\
\hline $\begin{array}{l}\text { Organization: Glass, Mass \& Insulation } \\
\text { Council of Australia, University of New South } \\
\text { Wales, Commonwealth and state governments }\end{array}$ & Date: Continuing \\
\hline End-use Sector: Residential building & $\begin{array}{l}\text { Affiliated/Future Projects: Passive solar } \\
\text { public housing in Sydney growth areas } \\
\text { (NERD\&D Program project); Energy Efficient } \\
\text { Australian Housing (consumers' guide); Home } \\
\text { Energy Rating Scheme/minimum energy- } \\
\text { efficiency standards for new housing (currently } \\
\text { being developed) }\end{array}$ \\
\hline $\begin{array}{l}\text { Description: Development of design and } \\
\text { materials criteria attuned for a range of local } \\
\text { climatic conditions to maximize the comfort and } \\
\text { energy efficiency of new houses }\end{array}$ & $\begin{array}{l}\text { Technology: Climate mapping and climate/ } \\
\text { comfort zone profile development; materials } \\
\text { characteristics; optimizing of glazing, thermal } \\
\text { mass and insulation levels }\end{array}$ \\
\hline $\begin{array}{l}\text { Results: Detailed profiles covering all elements } \\
\text { of design and construction for all temperate } \\
\text { zones in Australia; work remains to be done on } \\
\text { tropical zones; builders' and designers' manuals } \\
\text { completed and marketing package developed. }\end{array}$ & Reference: DPIE \\
\hline
\end{tabular}




\begin{tabular}{|c|c|}
\hline $\begin{array}{l}\text { Title: Passive Solar Housing in Sydney Growth } \\
\text { Areas }\end{array}$ & Project Type: Study/demonstration \\
\hline $\begin{array}{l}\text { Organization: University of New South Wales, } \\
\text { New South Wales and Commonwealth } \\
\text { governments }\end{array}$ & Date: Completed December 1986 \\
\hline End-use Sector: Residential building & $\begin{array}{l}\text { Affiliated/Future Projects: Five-star design } \\
\text { rating for new homes; Energy Efficient } \\
\text { Australian Housing (consumers guide); House } \\
\text { Energy Rating Scheme/minimum energy- } \\
\text { efficiency standards for new housing (currently } \\
\text { being developed) }\end{array}$ \\
\hline $\begin{array}{l}\text { Description: The design, construction, and } \\
\text { long-term monitoring of } 12 \text { energy-efficient and } \\
\text { three standard houses. }\end{array}$ & $\begin{array}{l}\text { Technology: Typical Australian house designs } \\
\text { with varying levels of insulation and thermal } \\
\text { mass }\end{array}$ \\
\hline $\begin{array}{l}\text { Results: With appropriate orientation of } \\
\text { windows, the use of wall insulation and added } \\
\text { thermal mass (concrete slab floors), it was } \\
\text { possible to reduce space heating/cooling } \\
\text { requirements by } 50 \%-90 \% \text {. In Australia, houses } \\
\text { typically have timber floors and no insulation in } \\
\text { the walls. }\end{array}$ & Reference: DPIE \\
\hline
\end{tabular}

Title: Organic Rankine Cycle (ORC) Engine for Electricity Generation by Hot Artesian Bores

Organization: Enreco Pty. Ltd./University of Sydney (through NERD\&D Program)

End-use Sector: Renewable energy; residential building; and agriculture

Description: Development of a prototype ORC engine for use on remote agricultural properties that have access to (and rely on) artesian bores for water supplies.

Results: The economics of the system is excellent where hot bores are available. Payback in terms of energy savings on the demonstration model was 6.5 years, but the unit was oversized and lower cost units would be more economical. There also have been productivity gains in the provision of water for stock.
Project Type: R\&D; study/demo

Date: Completed March 1987

Affiliated/Future Projects: None

Technology: ORC engine designed for low temperature $\left(75^{\circ}-100^{\circ} \mathrm{C}\right)$ artesian bore water

Reference: National Energy Research, Development \& Demonstration Program/DPIE 


\begin{tabular}{|c|c|}
\hline $\begin{array}{l}\text { Title: All-vanadium Redox Cell for Remote } \\
\text { Area Energy Storage }\end{array}$ & Project Type: R\&D \\
\hline $\begin{array}{l}\text { Organization: University of New South Wales } \\
\text { (through NERD\&D Program) }\end{array}$ & Date: Completed December 1986 \\
\hline $\begin{array}{l}\text { End-use Sector: Renewable energy; residential } \\
\text { buildings; and agriculture }\end{array}$ & Affiliated/Future Projects: None \\
\hline $\begin{array}{l}\text { Description: Development of a battery storage } \\
\text { system that improved the reliability and cost- } \\
\text { effectiveness of redox cells for use in RAPS }\end{array}$ & $\begin{array}{l}\text { Technology: Trials of a number of materials } \\
\text { for use in electrodes and membranes. The most } \\
\text { effective were demonstrated to be (a) carbon } \\
\text { felt RVC-2000 for both electrodes (b) Asahi } \\
\text { Selemion CMV cation selective membrane (c) } \\
\text { single cell consisting of two half-cells } \\
\text { containing vanadyl sulphate and sulfuric acid in } \\
\text { water connected to a tank containing additional } \\
\text { quantities of the vanadyl sulphate solution. }\end{array}$ \\
\hline $\begin{array}{l}\text { Results: System performed well with none of } \\
\text { the poor ampere/hour and watt/hour efficiencies } \\
\text { more common to iron/chromium redox cells. } \\
\text { Capable of rapid recharging if necessary by } \\
\text { draining solutions of discharged electrolyte and } \\
\text { replacing with solutions recharged separately. } \\
\text { Membrane life estimated to be at least two } \\
\text { years. Cost per kWh compares favorably with } \\
\text { lead-acid batteries. }\end{array}$ & $\begin{array}{l}\text { Reference: National Energy Research, } \\
\text { Development \& Demonstration Program/DPIE }\end{array}$ \\
\hline
\end{tabular}




\begin{tabular}{|c|c|}
\hline $\begin{array}{l}\text { Title: ASEAN-Australia Energy Cooperation } \\
\text { Project - Technical Group on Biomass }\end{array}$ & Project Type: R\&D \\
\hline $\begin{array}{l}\text { Organization: ASEAN-Australia Energy } \\
\text { Cooperation Project - Phase I }\end{array}$ & Date: 1982 ; continuing \\
\hline $\begin{array}{l}\text { End-use Sector: Renewable energy (biomass } \\
\text { for heat and power) }\end{array}$ & $\begin{array}{l}\text { Affiliated/Future Projects: ASEAN - } \\
\text { Australia Energy Cooperation Project - } \\
\text { Technical Group on Energy Conservation }\end{array}$ \\
\hline $\begin{array}{l}\text { Description: A joint project to help ASEAN } \\
\text { capitalize on its biomass resources through } \\
\text { enhancing ASEAN research capability and } \\
\text { developing fluidized bed combustion (EBC) and } \\
\text { gasification technologies. }\end{array}$ & $\begin{array}{l}\text { Technology: Fluidized bed combustion; } \\
\text { gasification }\end{array}$ \\
\hline $\begin{array}{l}\text { Results: ASEAN was able to study advanced } \\
\text { FBC technology as well as to design prototype } \\
\text { to a point where FBC units could be } \\
\text { manufactured on a commercial scale. } \\
\text { (a) Successful trials on tree species shown that } \\
\text { ASEAN could reclaim marginal lands for } \\
\text { production of biomass, (b) ASEAN's research } \\
\text { capabilities regarding gasification systems are } \\
\text { now at an advanced stage. }\end{array}$ & $\begin{array}{l}\text { Reference: Clean and Safe Energy Forever. } \\
\text { Proceedings of the } 1989 \text { Congress of the } \\
\text { International Solar Energy Society }\end{array}$ \\
\hline
\end{tabular}

Title: ASEAN-Australia Energy Cooperation Project - Technical Group on Conservation

Organization: ASEAN-SCNCER and Australian government

End-use Sector: All sectors

Description: A joint project to help ASEAN develop long-term energy conservation strategies and energy management

Results: (a) ASEAN agencies can now conduct energy audits. (b) ASEAN can now undertake advanced buildings simulations and modelling to improve designs of new structures and retrofits. (c) Agriculture and transportation sectors have benefitted from studies. (d) Energy Planners have skills and data to develop long-term strategies.
Project Type: Study/demo; audit; policy assessment

Date: 1982; continuing

Affiliated/Future Projects: ASEAN-Australia Energy Cooperation Project - Technical Group on Energy Conservation

Technology: Thermal Energy System Optimization, Linhoff/Pinch Techniques, LPG conversion kits, palm oil processing, building energy management, insulation, and heat pumps

Reference: ASEAN-Australia Energy Cooperation Project - Phase I 


\section{Brunei Darussalam}

Brunei Darussalam shares the island of Borneo with Malaysia and Indonesia. The land area totals $6,000 \mathrm{~km}^{2}$, and there is a population of 256,000 .

Evaluating the economy of Brunei is difficult both because it is a small country and because the country does not make estimates of economic indicators. The World Bank classifies Brunei as an upper-income country.

The economy of Brunei is highly dependent on oil and gas production, and most of the capacity is sold under fixed contract. Government expenditures are closely related to government revenues from the sale of oil. In 1988, the government experienced a fiscal deficit for the first time since 1930. Small fiscal deficits are expected for 1991 and 1992.

Brunei has diversified its economy, but the oil economy contributes about $60 \%$ of gross domestic product (GDP). Construction is the next largest sector comprising about 20\% of the GDP. Most of the other private sector activity is in the form of government contracts. For example, the government contracts building maintenance, refuse collection, and construction of public works.

The government recognizes the importance of diversification for the long-term economic welfare of the country. In the current five-year development plan, the government has outlined a plan to attract foreign investment and encourage local entrepreneurs.

Moderate growth in the Brunei economy will continue, with a GDP increase of $2 \%$ to $3 \%$ a year. If the price of oil rises sharply above \$US18 per barrel, the Pacific Economic Outlook forecasts growth in the $4 \%$ to $5 \%$ range. Brunei has accumulated official international reserves of US $\$ 20$ to US $\$ 25$ billion. These reserves earn a return for the country and could help support a development program. The Malay-Islamic monarchy usually guides development consistent with maintaining the traditional cultural heritage of the nation.

\section{Energy Use and Policy Issues}

Brunei is well endowed with natural reserves of oil. At one point, production reached 700,000 barrels per day. The country usually produces 150,000 barrels per day.

Electricity, water, telephones, and postal services are supplied by government departments. The government subsidizes the cost of these services to consumers.

\section{Energy Efficiency and Conservation}

No information on the situation of energy efficiency and conservation in Brunei is available, and no data describing energy-efficiency projects have been received from Brunei. 


\section{Canada}

Canada occupies the northern third of North America, having a total land area of 9,976 thousand $\mathrm{km}^{2}$. There are approximately 27 million people.

A parliamentary democracy governs Canada; an elected prime minister acts as the head of the state.

Canadian gross domestic product (GDP) reached US $\$ 570,150$ million in 1990 , up from US $\$ 52,870$ million in 1965 . This represents an average annual growth rate of $3.4 \%$ for the period 1980 to 1990 . The GDP rose $0.9 \%$ in 1990 . A GDP growth of $-1.1 \%$ was predicted for 1991 .

For 1990 , the lending rate averaged $14.1 \%$. The average rate of inflation was $4.4 \%$ from 1980 to 1990.

In 1990, exports totaled US $\$ 125,056$ million and imports totaled US\$ 115,882 million. Over the period 1980 to 1990 , exports grew at an average annual rate of $5.9 \%$, and imports grew at an average annual rate of $8.4 \%$. In 1990, exports weakened as the Canadian dollar appreciated. Manufacturing and construction contracted, and unemployment soared to $10.2 \%$.

For 1992, the Pacific Economic Outlook predicted the Canadian gross national product would increase $3.6 \%$. Exports should grow at a rate of $2.1 \%$. Inflation should be around $3 \%$, interest rates should be around $4.5 \%$, and unemployment will stay above $10 \%$.

\section{Energy Use and Policy Issues}

Canada's climate, geography, and industry make it a very energy-intensive country. In 1988, Canada's total energy output was 249.5 million tons of oil equivalent (Mtoe). By 2000, this is expected to increase to 331.8 Mtoe.

Per capita energy consumption equaled 10,009 kilograms of oil equivalent (kgoe) in 1990, up from 6,007 kgoe in 1965. For the period of 1980 to 1990 , energy consumption grew at an annual rate of 2.1\%. For the years between 1965 and 1980, energy consumption grew at an annual rate of $4.5 \%$. Canada uses the second highest amount of energy per capita in the world.

Canada possesses large quantities of almost every energy resource. Exports of oil, natural gas, and coal increased in 1988, and the International Energy Agency predicts this trend will continue.

In 1985, Canada deregulated its oil and gas industry and opened markets to competition. It hoped to increase the competition and increase the choices available to consumers. The government also deregulated the energy trade between the United States and Canada, which allows bilateral electricity trade.

Canadian electricity generation reached 101 gigawatts (GW) in 1988. The capacity came from hydroelectric (57\%), coal (19\%), nuclear $(12 \%)$, and petroleum (11\%). It is estimated that Canadian utilities will spend $C \$ 95$ million by 1998 to ensure adequate supplies of electricity.

The Canadian uranium industry is the leading producer and exporter in the world. At the end of 1988, there were 18 nuclear power plants having a capacity of $11.9 \mathrm{GW}$. The government of Canada plans to continue the research and development of nuclear power. 


\section{Energy Efficiency and Conservation}

The Canadian government and the Canadian universities conduct considerable research on renewable energy and conservation. The scope and accomplishments of their projects are large, and Canada is very advanced in these fields. The Canadian government implements energy efficiency and renewable research and development through Energy, Mines, and Resources of Canada (EMR), in particular the Efficiency and Alternative Energy Technology Branch (EAETB).

Government programs have been a significant factor in promoting energy conservation, fuel switching, and energy-efficiency investments. The large grant programs of the late 1970 s and early $1980 \mathrm{~s}$ allocated more than $\mathrm{C} \$ 550$ million annually to these programs.

In 1988, a new program was started, Energy Efficiency and Diversity, scheduled to run for five years at a cost of C $\$ 50$ million annually. It emphasized information programs to raise awareness of existing and new technologies, and involved consumers, industry, and other levels of government in partnership.

Between 1979 and 1989, EMR supported demonstrations of energy conservation and renewable technologies. This was done through a group of programs that included R-2000 (high-efficiency housing); the Remote Community Demonstration Program; the Solar Energy Demonstration; the Energy Task Forces; the Forest Industry Renewable Energy Program; Pro-Trucker; and the Federal Energy Management Program. These programs covered industrial demonstrations, buildings, transportation, alternative fuels, energy systems, bioenergy, and renewables.

The Canada Centre for Mineral and Energy Technology (CANMET) is the main research and technology development arm of EMR. With more than 550 professional scientists, engineers, and technicians on staff, and research and testing complexes in Nova Scotia, Quebec, Ontario, and Alberta, CANMET is one of the largest technology development centers in the country.

Through exploratory research, commercial and cost-shared $R \& D$, product testing, and technology transfer, CANMET assists Canada's minerals, metals, and energy industries.

Under a new mandate, CANMET is working more closely with Canadian businesses and institutions. CANMET's EAETB includes the Energy Efficiency Division, the Alternative Energy Division, and the Energy Diversification Research Laboratory. The branch is responsible for research, development, and the commercialization of technologies in the fields of energy efficiency, renewable energy, and alternative transportation fuels.

EAETB also provides technical advice to other government agencies and technical support to the policy and program initiatives of EMR, such as the Energy Efficiency and Diversity Initiative and the Panel on Energy Research and Development.

Canada's support of energy efficiency is expected to increase as a result of the energy component of federal environmental policy, which is known as the Green Plan. Environment Canada is the lead agency for implementation of this effort, but other departments, such as EMR, are involved as well.

In 1991, Canada passed the National Energy Efficiency and Alternative Energy Act. The act delivers on the Green Plan commitment that legislation would be introduced to allow the federal government to set minimum energy-efficiency standards on equipment, to require the energy consumption labeling of 
equipment, and to gather information and data on Canadian energy consumption and the use of alternative energy.

The current EMR efficiency and alternative energy program has the following main components:

- General

- Energy Innovators Ventures-to encourage major energy-using organizations to exploit energy-efficiency and alternative energy opportunities by reaching agreements with them on performance and/or prescriptive initiatives they will undertake.

- National Energy Use Data Base-to improve the knowledge about the use of energy in Canada by organizing and expanding a national data base in this area.

- Integrated Resource Planning-to improve the effectiveness of resource planning by electrical and natural gas utilities by encouraging the increased integration of demand-side management (DSM), nonutility generation, cogeneration, and district heating and cooling into the utility planning process.

- Energy efficiency in equipment

- Energy-Efficiency Standards for Equipment-to phase out inefficient equipment from the Canadian market by establishing, in cooperation with provincial governments, national energy-efficiency regulations for equipment.

- Energy Equipment Labeling - to require manufacturers to affix Energuide labels to equipment to inform consumers about the product's energy consumption.

- Buildings

- Building Energy Code-to develop national model energy codes and specify minimum acceptable levels of thermal performance; and to promote their incorporation into provincial/municipal building codes.

- Building Information Transfer-to promote the adoption of energy-efficient technology by increasing public and industry awareness of energy-efficiency opportunities and products available to the building sector.

- R-2000 Partnership-to promote energy-efficient houses and to train builders in the techniques required to design, construct, and market these houses.

- Buildings R\&D and Technology Transfer-to develop and commercialize energy-efficient and passive solar technologies in the residential and commercial sectors of the economy.

- Industry

- Industry Energy Efficiency-to help reduce emissions of $\mathrm{CO}_{2}$ and to enhance Canada's industrial competitiveness by increasing the efficiency of energy use in goods-producing industries. 
- Industry Targeted Research and Development-to identify and foster opportunities for energy management research and development, field trials, and technology transfer opportunities that could improve energy efficiency, reduce environmental emissions, and improve industrial productivity.

- Alternative transportation fuels

- Technology and Market Development- to promote the development and market penetration of alternative fuel vehicles in Canada.

- Research and Development-to promote research on and development of alternative transportation fuels such as natural gas, propane, alcohol fuel, and electric vehicles.

- Environmental stewardship program

- Federal Buildings Initiative-to assist federal departments to improve the energy efficiency of their facilities through a variety of techniques, including savings-financing.

Provincial governments and research organizations also support research and development on energy efficiency and renewable energy under mandates to encourage and facilitate scientific and technological development.

Demonstrations of technical prototypes based on these research activities are undertaken by some provincial governments. For example, the Ontario Ministry of Energy has contributed C $\$ 6$ million over the last three years toward joint government/industry projects, including initial technical demonstrations of innovative energy technologies under the EnerSearch Program.

All provincial governments mandated with energy technology developments are members of the Interprovincial Advisory Committee on Energy (IPACE). Two IPACE subcommittees are currently in place: (1) Coal Coordination and (2) Conservation and Renewable Energy. The purposes of these committees are for discussions of areas of common concern and coordination of provincial efforts.

Utilities continue to work on projects that promote energy efficiency through both technical and market development demonstrations. DSM is now a major area of interest to the Canadian Electrical Association and its member utilities.

Trade organizations such as the Solar Energy Society of Canada and the Canadian Wind Energy Association actively promote renewable energy and conservation by sponsoring conferences, publishing newsletters, and lobbying the government for support of renewable energy technologies.

\section{Bibliography}

CADDET Strategy Plan, December 2, 1991

CANMET IS, Canada Center for Minerals and Energy Technology

Canada's Green Plan (news release dated October 29, 1991)

Energy Partnership: Programs for 1991-92, Ministry of Energy of the Province of Ontario 
Energy Solutions for Today: 14th Annual Conference of the Solar Energy Society of Canada Inc. Proceedings; Solar Energy Society of Canada; June 1988

Renewables-A Clean Energy Solution Conference Proceedings, 15th Annual Conference of the Solar Energy Society of Canada; June 1989

Seventh Canadian Bioenergy $R \& D$ Seminar Proceedings, Bioenergy Development Program: Energy, Mines and Resources Canada; April 1989

Technologies for a Cleaner Environment, 1991

The Leading Edge '84: The Seventh Annual Wind Energy Symposium Proceedings; National Research Council of Canada; December 1984 


\begin{tabular}{|c|c|}
\hline Title: The Pyrocore Ceramic Matrix Burner & Project Type: R\&D \\
\hline Organization: Esso Petroleum Canada & Date: 1989 \\
\hline End-use Sector: Industry (Process) & Affiliated/Future Projects: None \\
\hline $\begin{array}{l}\text { Description: Research and development into a } \\
\text { low nitrogen oxide emissions burner that would } \\
\text { allow industries to comply more cost-effectively } \\
\text { with emissions standards. }\end{array}$ & $\begin{array}{l}\text { Technology: Ceramix fiber-matrix burners uses } \\
\text { a porous surface of ceramic fibers to burn pre- } \\
\text { mixed fuel gas and air resulting in a surface that } \\
\text { radiates high levels of infrared energy while } \\
\text { reducing nitrogen oxide emissions }\end{array}$ \\
\hline $\begin{array}{l}\text { Results: High combustion efficiency, low } \\
\text { nitrogen oxide emissions, lower investment } \\
\text { costs, low maintenance, low noise. }\end{array}$ & $\begin{array}{l}\text { Reference: Center for the Analysis and Dis- } \\
\text { semination of Demonstrated Energy } \\
\text { Technologies (CADETT), International Energy } \\
\text { Agency (IEA) }\end{array}$ \\
\hline
\end{tabular}

\begin{tabular}{|c|c|}
\hline Title: Passive Solar Technology & Project Type: $\quad$ R\&D; study/demo \\
\hline $\begin{array}{l}\text { Organization: Energy, Mines, and Resources } \\
\text { of Canada (EMR), universities }\end{array}$ & Date: Ongoing \\
\hline $\begin{array}{l}\text { End-use Sector: Residential, commercial } \\
\text { buildings }\end{array}$ & $\begin{array}{l}\text { Affiliated/Future Projects: Low Energy } \\
\text { Housing; The Solar Energy Society holds } \\
\text { conferences annually. }\end{array}$ \\
\hline $\begin{array}{l}\text { Description: Researchers developed passive } \\
\text { solar homes, modeling systems, demonstration } \\
\text { homes, and solar collectors. They also studied } \\
\text { daylighting, agricultural drying, and active solar } \\
\text { technologies. }\end{array}$ & Technology: Passive solar \\
\hline $\begin{array}{l}\text { Results: Researchers developed superglazing } \\
\text { for windows, computer models, and design } \\
\text { guides. }\end{array}$ & Reference: Solar Energy Society of Canada \\
\hline
\end{tabular}




\begin{tabular}{|c|c|}
\hline Title: Habitisol House & Project Type: Study/demonstration \\
\hline $\begin{array}{l}\text { Organization: International Energy Agency } \\
\text { (IEA), Thermtech Incorporated }\end{array}$ & Date: 1991 \\
\hline End-use Sector: Residential building & Affiliated/Future Projects: Unknown \\
\hline $\begin{array}{l}\text { Description: A } 250-\mathrm{m}^{2} \text { factory-built pre- } \\
\text { fabricated bungalow uses a fully glazed } \\
\text { sunspace, thermal storage, and a small } \\
\text { swimming pool to reduce heating costs. }\end{array}$ & Technology: Passive solar \\
\hline $\begin{array}{l}\text { Results: Passive solar contributed } 28 \% \text { of the } \\
\text { heating, internal gains } 34 \% \text {, and electric heating } \\
38 \% \text {. }\end{array}$ & Reference: IEA CADDET Program \\
\hline
\end{tabular}

\begin{tabular}{|l|l|}
\hline Title: Solar Light Pipe & Project Type: Study/demonstration \\
\hdashline Organization: IEA CADDET, TIR Systems & Date: 1991 \\
Limited, Konvey Construction & \\
\hdashline End-use Sector: Commercial building & Affiliated/Future Projects: Unknown \\
\hdashline $\begin{array}{l}\text { Description: Eight tracking mirrors funnel light } \\
\text { down plastic pipes into an office. A A high- } \\
\text { powered metal halide bulb provides light for }\end{array}$ & \\
nights and cloudy days. & \\
\hdashline $\begin{array}{l}\text { Results: } \text { The solar lighting system illuminates } \\
\text { 244 } \mathrm{m}^{2} \text { on the fifth floor of an office complex. } \\
\text { It provides light without heat and reduces } \\
\text { worker fatigue. }\end{array}$ & \\
\hline
\end{tabular}




\begin{tabular}{l|l|}
\hline Title: Energy Storage & Project Type: R\&D \\
\hdashline Organization: IEA (Canada, United States, and \\
others)
\end{tabular}

\begin{tabular}{|c|c|}
\hline $\begin{array}{l}\text { Title: Demand-Controlled Ventilation in } \\
\text { Buildings }\end{array}$ & Project Type: R\&D \\
\hline $\begin{array}{l}\text { Organization: IEA (participants are Canada } \\
\text { and seven others) }\end{array}$ & Date: 1988 ; continuing \\
\hline End-use Sector: Residential building & Affiliated/Future Projects: None \\
\hline $\begin{array}{l}\text { Description: A review and assessment of } \\
\text { current methods for regulating the quality of } \\
\text { indoor air. Goal is to help in the design, } \\
\text { operation, and maintenance of new } \\
\text { automatically controlled building ventilation } \\
\text { systems. Concentrates on demand-controlled } \\
\text { systems that use sensors to monitor air } \\
\text { pollutants and trigger automatic systems to } \\
\text { improve ventilation. }\end{array}$ & $\begin{array}{l}\text { Technology: Sensors, improved ventilation } \\
\text { technology }\end{array}$ \\
\hline $\begin{array}{l}\text { Results: Participants are producing a reference } \\
\text { book on the design of demand-controlled } \\
\text { ventilation systems, including test results. }\end{array}$ & $\begin{array}{l}\text { Reference: IEA Joint R\&D Projects (April } \\
\text { 1990) }\end{array}$ \\
\hline
\end{tabular}




\begin{tabular}{l:l}
\hline Title: Passive Solar Design for Buildings & Project Type: R\&D \\
\hdashline Organization: IEA (participants are Canada, \\
New Zealand, United States, and 13 others) \\
\hdashline End-use Sector: Residential, commercial \\
buildings
\end{tabular}

\begin{tabular}{l|l|}
\hline Title: District Heating Technology & Project Type: R\&D \\
\hdashline Organization: IEA (participants are Canada, \\
United States and eight others)
\end{tabular}




\begin{tabular}{|c|c|}
\hline Title: Strathcona Small Hydro Project & Project Type: Study/demonstration \\
\hline $\begin{array}{l}\text { Organization: Strathcona Park Lodge, } \\
\text { Vancouver }\end{array}$ & Date: 1988 \\
\hline $\begin{array}{l}\text { End-use Sector: Commercial building; } \\
\text { renewable energy }\end{array}$ & Affiliated/Future Projects: Unknown \\
\hline $\begin{array}{l}\text { Description: The project uses a } 75-\mathrm{kW} \text { twin } \\
\text { nozzle pelton wheel turbine to supply power to } \\
\text { an outdoor education school. }\end{array}$ & Technology: Mini-hydro, Pelton wheel \\
\hline $\begin{array}{l}\text { Results: The project cost } \$ 236,000 \text {. It } \\
\text { displaced } \$ 37,000 \text { per year in diesel costs. }\end{array}$ & Reference: Solar Energy Society of Canada \\
\hline
\end{tabular}

Title: Computer-controlled HVAC (heating,
ventilating, and air conditioning) in Ottawa
Courthouse




\begin{tabular}{|c|c|}
\hline Title: Photovoltaics (PV) in Canada & Project Type: R\&D; study/demo \\
\hline Organization: Industry, EMR & Date: Ongoing \\
\hline End-use Sector: Renewable energy & $\begin{array}{l}\text { Affiliated/Future Projects: Canadians set up a } \\
\text { PV manufacturing company in Sri Lanka. }\end{array}$ \\
\hline $\begin{array}{l}\text { Description: PV systems have been used for } \\
\text { irrigation, telecommunications, desalination, } \\
\text { remote power, and consumer products. }\end{array}$ & Technology: PV, batteries, and system design \\
\hline $\begin{array}{l}\text { Results: University researchers developed and } \\
\text { tested PV systems. EMR funds resource } \\
\text { assessments. There is a small industry involved } \\
\text { with installations. }\end{array}$ & Reference: Solar Energy Society of Canada \\
\hline
\end{tabular}

\begin{tabular}{l|l}
\hline Title: Canadian Renewable Energy & Project Type: Policy assessment; study/demo \\
Demonstration (CREDA) Program & Date: $1978 ;$ continuing \\
\hdashline Organization: National Energy Program & Affiliated/Future Projects: Unknown \\
\hdashline End-use Sector: All sectors & Technology: All renewable energy sources \\
\hdashline $\begin{array}{l}\text { Description: A program to provide funding to } \\
\text { demonstrate the technical and commercial } \\
\text { viability of renewables. }\end{array}$ & \\
\hdashline $\begin{array}{l}\text { Results: CREDA funds biomass energy, wind } \\
\text { energy, and solar energy. }\end{array}$ & $\begin{array}{l}\text { Reference: Seventh Canadian Bioenergy R\&D } \\
\text { Seminar }\end{array}$ \\
\hline
\end{tabular}




\section{Chinese Taipei}

Chinese Taipei occupies an island of some $36,100 \mathrm{~km}^{2}$ off the southeastern coast of mainland China. Twenty million people, mostly of Chinese origin, populate the island, making it one of the world's most densely populated countries.

Chinese Taipei possesses very few natural resources. However, through joint efforts among the people, industry, and government, Chinese Taipei has achieved an annual gross domestic product (GDP) growth of approximately $9 \%$ over the past 30 years. There are four key reasons for the success: an industrious, well-educated work force, high savings and investment, low labor costs, and sound macroeconomic management.

Chinese Taipei is a small open economy based on manufacturing products for export.

The government keeps tight control on fiscal policy and monetary policy. Revenues at all levels of government, including the state-run companies, typically equal expenditures. Debt service totals approximately $0.5 \%$ of exports. Government policies kept inflation to around $4.4 \%$ per year during 1980 to 1990.

Over the last 20 years, industry has accounted for $35 \%$ to $40 \%$ of gross national product (GNP), and manufactured goods exceeded $50 \%$ of total export shipments. Today, these goods account for $95 \%$ of sales abroad. Leading exports include textiles, machinery, metal products, and transportation equipment.

In 1989 , exports totaled US $\$ 84.28$ billion and imports totaled US\$70.36 billion. The United States is Chinese Taipei's leading trading partner, buying 32.4\% of the country's exports. Japan and Hong Kong also are large trading partners, each accounting for roughly $12 \%$ of Chinese Taipei's exports. Another important trading partner is the People's Republic of China; $15 \%$ of Chinese Taipei's exports pass through Hong Kong to mainland China.

Banking and financial markets are developing in Chinese Taipei. The country has a fully functioning money market, which began in 1976. It includes T-bills, commercial paper, bankers acceptances, and negotiable certificates of deposit. The total outstanding money was US $\$ 157.9$ million in 1990 . Shortterm debt instruments (less than one year), like government and corporate bonds, started trading in the mid-1980s. Long-term bond issues amounted to $\$ 16.3$ billion in 1990 .

With a new six-year development plan (1991 to 1996), the government hopes to shift Chinese Taipei's economy towards the domestic and service market sectors. This plan calls for US $\$ 303$ billion in spending and expects to raise per capita national income, balance economic growth and development, and continue industrial development. Transportation and communications systems will absorb one-third of the capital inflow. 


\section{Energy Use and Policy Issues}

Economic growth within Chinese Taipei has increased the demand for energy. Under the Ministry of Economic Affairs (MOEA), the government formed the Energy Commission to execute energy policy, planning, and law. In recent years, the Energy Commission has implemented a wide variety of energy conservation laws and has promoted efficient use of energy.

Total energy consumption in Chinese Taipei increased from 11 million kiloliters of oil equivalent (kLoe) in 1971 to 54 million kLoe in 1991. The annual average growth rate for this period was $8.3 \%$. The Energy Commission predicts energy demand will increase to 112 million kLoe by the year 2010 .

Chinese Taipei's per capita use of energy increased from 759 kLoe in 1971 to 2,641 kLoe in 1991, an average annual growth rate of $6.5 \%$.

Chinese Taipei imports $95 \%$ of its energy. The energy supply consists of the following: oil (53\%), coal $(24 \%)$, natural gas $(2 \%)$, hydropower $(2 \%)$, nuclear $(15 \%)$, and liquid natural gas $(4 \%)$. By the year 2010, the Energy Commission predicts the energy supply will consist of the following: oil $(35 \%)$, coal (26\%), natural gas (20\%), hydropower (3\%), nuclear (14\%), and new energy (2\%).

Two parastatal companies dominate the energy industry: Taipower and Chinese Petroleum. They operate 57 power stations on Chinese Taipei and the surrounding islands. As of February 1992, these two companies operated 35 hydropower stations, 19 thermal power stations, and 3 nuclear power stations.

Demand for energy came from the following market sectors in 1991: industry (52\%), transportation $(15 \%)$, agriculture $(3 \%)$, residential $(12 \%)$, commercial $(4 \%)$, feedstocks $(8 \%)$, and others $(6 \%)$.

Taipower generates, transmits, and distributes electricity in Chinese Taipei. In 1991, the total installed capacity was 18,383 megawatts (MW) and total consumption neared 91.2 billion kilowatt-hours (kWh). Sources were hydro (14\%), coal-fired (26\%), oil-fired (28\%), gas-fired (4\%), and nuclear (28\%). The peak load in 1991 was $19,174 \mathrm{MW}$, an $8.6 \%$ increase over 1990 . The average load was $10,174 \mathrm{MW}$, an $8.6 \%$ increase over 1990 . Industry consumed $59 \%$ of the electricity, followed by residential users $(20 \%)$ and commercial users $(9 \%)$.

In 1973, the MOEA began to establish national energy policies. In 1979, MOEA formed the Energy Commission to enforce energy law and to promote energy technology. In 1990, the Energy Commission revised the national energy policy to minimize environmental degradation. According to the executive order, the national energy policy should

- Assure stable supply of energy by diversifying the sources of primary energy

- Promote rational energy pricing to reflect the true cost of energy

- Increase the efficiency of energy use

- Prevent energy-related environmental pollution

- Strengthen research and development (R\&D) and encourage private sector involvement

- Promote energy education. 


\section{Energy Efficiency and Conservation}

Energy-efficiency programs are seen as being important for the following reasons: economic development depends on imported energy development; electrical shortages have become an important issue in recent years; the energy intensive industry's share of consumption is still high; and the drop in energy prices has adversely affected energy conservation. It is the government's policy that energy prices should reflect actual costs and electricity prices should be structured to promote off-peak use of power and load leveling.

It is the government's policy that the industrial structure should be improved (less emphasis on energy-intensive industry) and energy productivity enhanced. Conservation programs should assist all enterprises in strengthening their energy management and promoting the installation of energy-saving equipment. Technical assistance should be provided to industry to encourage conservation. Interurban and urban mass transit should be accelerated, and motor vehicle fuel economy standards are to be continued. Buildings standards, as well as standards for energy-consuming equipment and devices, should be implemented.

R\&D policy directs that programs should be undertaken concerning the technical aspects of energy conversion, distribution, storage, utilization, and conservation. R\&D should be undertaken with private sector involvement.

Education and publicity should encourage educational institutions at all levels to foster energyconserving habits among students. Active efforts to promote energy education should be pursued.

Chinese Taipei also has promoted the use of renewable energy. The government has funded R\&D to develop and demonstrate uses for renewable technologies. The Energy Research Laboratory (ERL) administers these programs. In 1991, ERL was conducting research in at least 22 fields related to energy use.

The Energy Conservation Program in Chinese Taipei includes pricing policy, utilization policy, R\&D, education, and publicity. The government has proposed measures that, if fully implemented, would reduce consumption by $1.8 \%$ per year. Based on past experience, the annual increment in peak power could be $1,990 \mathrm{MW}$; if conservation were fully implemented, that could be reduced by $960 \mathrm{MW}$. The projects of the Comprehensive Energy Conservation Program for the next six years that have been planned to achieve these energy-efficiency and load-shedding targets include the following:

1. Regulations and Standards
a. Energy industry efficiency
b. Energy audit
c. Appliance efficiency standard
d. Appliance labeling
e. Vehicular fuel economy
f. Government saving activities
g. Transportation system
h. Building code 
2. Financial and Tax Incentives
a. R\&D in energy-saving devices
b. Energy conservation investment
c. Peak-shaving devices

3. Technology Research and Development
a. R\&D
b. Technology transfer
c. Certificate service
d. Technical assistance

4. Information and Education
a. School education
b. Professional training
c. Electricity-saving awareness
d. Oil-saving awareness
e. Publicity campaigns

\section{Bibliography}

Energy Statistical Data Book 1990; Energy Commission, Ministry of Economic Affairs; March 1991

Energy Conservation Program in Chinese Taipei; Energy Commission, Ministry of Economic Affairs

Energy-Efficiency Improvement in Industrial and Commercial Sectors; Energy Technical Service Center; April 1992

Energy Balances in Chinese Taipei, Republic of China, 1991; Energy Commission, Ministry of Economic Affairs; February 1992

ERL Energy Technology; Industrial Technology Research Institute

Chinese Taipei: Phase II of an Economic Miracle; Susumu Kato, Goldman Sachs Economic Research Group; April 1992

The Energy Situation in Chinese Taipei, Republic of China; Energy Commission, Ministry of Economic Affairs; February 1992 


\begin{tabular}{|c|c|}
\hline Title: Energy Audit Program & Project Type: Policy assessment \\
\hline $\begin{array}{l}\text { Organization: Ministry of Economic Affairs } \\
\text { (MOEA) }\end{array}$ & Date: 1992 ; continuing \\
\hline End-use Sector: Industry & $\begin{array}{l}\text { Affiliated/Future Projects: Comprehensive } \\
\text { Energy Conservation Programs, Energy } \\
\text { Management Information System }\end{array}$ \\
\hline $\begin{array}{l}\text { Description: According to the energy } \\
\text { management law, all firms consuming more than } \\
\text { a specific amount of energy must conduct } \\
\text { energy audits and submit plans for energy } \\
\text { conservation programs. The law affects } 3,800 \\
\text { factories using } 40 \% \text { of the total energy in } \\
\text { Chinese Taipei and } 50 \% \text { of the peak load. }\end{array}$ & Technology: Conservation \\
\hline $\begin{array}{l}\text { Results: The program has raised the unit } \\
\text { product per unit of energy at factories in at least } \\
\text { six industries. }\end{array}$ & $\begin{array}{l}\text { Reference: Energy Technical Service Center } \\
\text { (ETSC), APEC questionnaire }\end{array}$ \\
\hline
\end{tabular}

\begin{tabular}{|c|c|}
\hline $\begin{array}{l}\text { Title: Energy-saving Technical Service for } \\
\text { Manufacturing Factories and Oil Refineries }\end{array}$ & Project Type: Policy assessment \\
\hline $\begin{array}{l}\text { Organization: Energy Technical Service } \\
\text { Center (ETSC) }\end{array}$ & Date: 1991 to 1993 \\
\hline End-use Sector: Industry & $\begin{array}{l}\text { Affiliated/Future Projects: From } 1992 \text { to } \\
\text { 1993, more than } 600 \text { factories will be audited; } \\
\text { technical service programs }\end{array}$ \\
\hline $\begin{array}{l}\text { Description: The project will conduct energy } \\
\text { audits of } 820 \text { factories for } 100 \text { types of energy } \\
\text { equipment and five types of furnaces. A total of } \\
572 \text { suggestions was made for improved } \\
\text { efficiency. Efficiency will be improved at oil } \\
\text { refineries. }\end{array}$ & Technology: Conservation \\
\hline $\begin{array}{l}\text { Results: In 1991, } 207 \text { factories were audited } \\
\text { for a total savings of NT } \$ 68 \text { million or } 33.5 \\
\text { million kWh. Unit energy consumption per liter } \\
\text { of crude has improved from } 149.1 \text { (Mkcal) to } \\
140.6 \text { (Mkcal). }\end{array}$ & $\begin{array}{l}\text { Reference: Energy Technical and Service } \\
\text { Center }\end{array}$ \\
\hline
\end{tabular}




\begin{tabular}{|c|c|}
\hline Title: Cogeneration System Promotion Program & Project Type: Policy assessment \\
\hline $\begin{array}{l}\text { Organization: MOEA, Energy Technical and } \\
\text { Service Center }\end{array}$ & Date: 1988; continuing \\
\hline End-use Sector: Industry & $\begin{array}{l}\text { Affiliated/Future Projects: Technical service } \\
\text { programs }\end{array}$ \\
\hline $\begin{array}{l}\text { Description: A government policy titled } \\
\text { "Measures for Promoting Cogeneration } \\
\text { Applications" was passed in 1988. The program } \\
\text { initiated incentives in the form of low interest } \\
\text { loans and tax credits, and guaranteed the buy- } \\
\text { back of surplus electricity. }\end{array}$ & Technology: Cogeneration \\
\hline $\begin{array}{l}\text { Results: Cogeneration capacity increased in the } \\
\text { last few years. In } 1991 \text {, there were } 51 \text { plants } \\
\text { equipped with } 1,517-\mathrm{MW} \text { cogeneration capacity. } \\
\text { There were also } 1,339 \mathrm{MW} \text { under construction. } \\
\text { About } 1,600 \text { potential users were contacted. }\end{array}$ & $\begin{array}{l}\text { Reference: Questionnaire, Energy Technical } \\
\text { and Service Center }\end{array}$ \\
\hline
\end{tabular}

\begin{tabular}{|c|c|}
\hline Title: Vehicular Fuel Economy & Project Type: Policy assessment \\
\hline Organization: MOEA & Date: January 1988; continuing \\
\hline End-use Sector: Transportation & $\begin{array}{l}\text { Affiliated/Future Projects: Comprehensive } \\
\text { Energy Conservation Programs. A mass } \\
\text { transportation system is also under } \\
\text { consideration. }\end{array}$ \\
\hline $\begin{array}{l}\text { Description: The government implemented fuel } \\
\text { economy standards that have gone into effect in } \\
\text { three phases: } 1988,1990,1992 \text {. }\end{array}$ & Technology: \\
\hline $\begin{array}{l}\text { Results: The savings in fuel are expected to be } \\
5 \% \text { to } 7 \% \text { for passenger cars and } 11 \% \text { to } 13 \% \\
\text { for motorcycles. The annual gasoline savings } \\
\text { will be between } 380 \text { and } 490 \text { million liters. }\end{array}$ & Reference: ETSC, APEC questionnaire \\
\hline
\end{tabular}




\begin{tabular}{|c|c|}
\hline $\begin{array}{l}\text { Title: Energy-Efficiency Standard for Fishing } \\
\text { Boat Engines }\end{array}$ & $\begin{array}{l}\text { Project Type: Standards and codes; policy } \\
\text { assessment }\end{array}$ \\
\hline Organization: MOEA & Date: 1989 ; continuing \\
\hline End-use Sector: Transportation & $\begin{array}{l}\text { Affiliated/Future Projects: Comprehensive } \\
\text { Energy Conservation Programs }\end{array}$ \\
\hline $\begin{array}{l}\text { Description: Imported engines and new } \\
\text { engines must meet efficiency standards. }\end{array}$ & Technology: \\
\hline $\begin{array}{l}\text { Results: The cost of fuel will decrease NT\$140 } \\
\text { million yearly. }\end{array}$ & Reference: ETSC, APEC questionnaire \\
\hline
\end{tabular}

\begin{tabular}{|c|c|}
\hline $\begin{array}{l}\text { Title: Solar Hot Water System Popularization } \\
\text { Program }\end{array}$ & Project Type: Policy assessment; study/demo \\
\hline Organization: MOEA & Date: January 1986 to 1991 \\
\hline $\begin{array}{l}\text { End-use Sector: Residential building (water } \\
\text { heating) }\end{array}$ & $\begin{array}{l}\text { Affiliated/Future Projects: Comprehensive } \\
\text { Energy Conservation Programs }\end{array}$ \\
\hline $\begin{array}{l}\text { Description: The popularization program } \\
\text { consisted of technological development, system } \\
\text { demonstration, and subsidies. The subsidies can } \\
\text { be as much as NT } \$ 1,000 \text { per square meter }\left(\mathrm{m}^{2}\right) \text {. }\end{array}$ & Technology: Solar hot water \\
\hline $\begin{array}{l}\text { Results: The subsidized installation area of } \\
\text { solar hot water collectors reached } 247,000 \mathrm{~m}^{2} \text { in } \\
1990 \text {. Consumers are installing heaters at the } \\
\text { rate of approximately } 55,000 \mathrm{~m}^{2} \text { per year. The } \\
\text { number of solar hot water manufacturers has } \\
\text { increased from } 23 \text { in } 1986 \text { to } 60 \text { in } 1990 .\end{array}$ & Reference: ETSC, APEC questionnaire \\
\hline
\end{tabular}

\begin{tabular}{|l|l|}
\hline Title: Service for Air Conditioners & $\begin{array}{l}\text { Project Type: Study/demonstration } \\
\text { Organization: MOEA }\end{array}$ \\
\hdashline $\begin{array}{l}\text { End-use Sector: Commercial building (air } \\
\text { conditioning) }\end{array}$ & $\begin{array}{l}\text { Affiliated/Future Projects: Technical service } \\
\text { programs. Increased efficiency in vending } \\
\text { machines also has been considered. }\end{array}$ \\
\hdashline $\begin{array}{l}\text { Description: A task force was organized to } \\
\text { service 640 large air conditioning systems. }\end{array}$ & \begin{tabular}{l} 
Technology: \\
\hdashline $\begin{array}{l}\text { Results: The program should reduce 40 MW of } \\
\text { summer peak load. }\end{array}$
\end{tabular} \\
\hline
\end{tabular}




\begin{tabular}{|c|c|}
\hline $\begin{array}{l}\text { Title: Air Conditioning Systems Using Thermal } \\
\text { Ice Storage }\end{array}$ & Project Type: Study/demonstration \\
\hline $\begin{array}{l}\text { Organization: MOEA. Energy Technical and } \\
\text { Service Center. }\end{array}$ & Date: 1990 to 1993 \\
\hline $\begin{array}{l}\text { End-use Sector: Commercial building (air } \\
\text { conditioning) }\end{array}$ & $\begin{array}{l}\text { Affiliated/Future Projects: Technical service } \\
\text { programs }\end{array}$ \\
\hline $\begin{array}{l}\text { Description: The ETSC will promote the use } \\
\text { of thermal energy storage for large central air } \\
\text { conditioning users. Ice will be made during off- } \\
\text { peak hours for use in air conditioning systems. } \\
\text { The project will service } 160 \text { out of } 300 \text { potential } \\
\text { users. }\end{array}$ & Technology: Thermal energy storage systems \\
\hline $\begin{array}{l}\text { Results: Approximately } 90 \text { thermal storage } \\
\text { systems have been set up. The project will shift } \\
160 \mathrm{MW} \text { of Taipower's peak-load. } 160 \mathrm{MW} \text { is } \\
4 \% \text { of TPC air conditioning peak load. }\end{array}$ & $\begin{array}{l}\text { Reference: APEC questionnaire, Energy } \\
\text { Technical and Service Center }\end{array}$ \\
\hline
\end{tabular}

\begin{tabular}{|c|c|}
\hline Title: Five-Year Energy Conservation Program & Project Type: Policy assessment \\
\hline $\begin{array}{l}\text { Organization: MOEA, Energy Conservation } \\
\text { Task Force, China Technical Consultants }\end{array}$ & Date: June 1987 to 1991 \\
\hline End-use Sector: Industry; commercial building & $\begin{array}{l}\text { Affiliated/Future Projects: National Six Year } \\
\text { Development Plan }\end{array}$ \\
\hline $\begin{array}{l}\text { Description: A five-year energy conservation } \\
\text { program was planned to implement a } \\
\text { conservation project, publish information, } \\
\text { provide training, and promote conservation. } \\
\text { The program has four parts: Regulations \& } \\
\text { Standards, Financial \& Tax Incentives, Research } \\
\text { \& Development, and Information \& Education. }\end{array}$ & Technology: Conservation \\
\hline $\begin{array}{l}\text { Results: The program has saved NT } \$ 7,617 \\
\text { million worth of energy. }\end{array}$ & Reference: Energy Technical Service Center \\
\hline
\end{tabular}




\begin{tabular}{|c|c|}
\hline Title: Energy Pricing Policy & Project Type: Policy assessment \\
\hline Organization: MOEA & Date: 1991 to 1996 \\
\hline $\begin{array}{l}\text { End-use Sector: Commercial, residential } \\
\text { buildings; industry }\end{array}$ & Affiliated/Future Projects: \\
\hline $\begin{array}{l}\text { Description: As part of the conservation } \\
\text { program, the pricing structure will be revamped } \\
\text { so that the price of energy will represent the } \\
\text { actual cost. }\end{array}$ & Technology: Conservation \\
\hline $\begin{array}{l}\text { Results: The utilities have set peak and off- } \\
\text { peak tariffs. }\end{array}$ & Reference: Energy Conservation in Taiwan \\
\hline
\end{tabular}

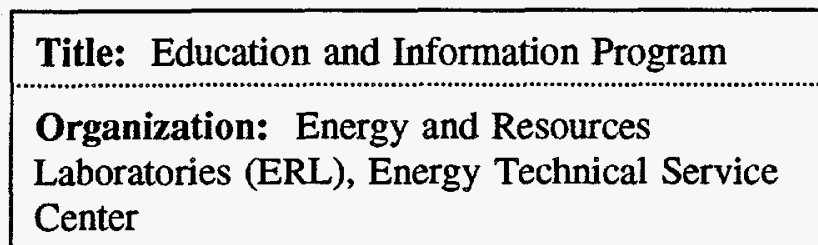

End-use Sector: Commercial, residential buildings; industry

Description: The education campaign has five areas: School Education, Training, Electricity Saving Awareness, Oil and Gas Saving Awareness, and General Publicity Campaigns.

Results: A total of 9,445 persons was trained as energy managers.

Project Type: Policy assessment

Date: 1980; continuing

\section{Affiliated/Future Projects:}

Technology: Conservation

Title: Energy Appliances Standard Program and Labeling Program

Organization: MOEA, Energy Technical Service Center (ETSC)

End-use Sector: Residential, commercial buildings (appliance manufacturers)

Description: ETSC set minimum standards for appliance efficiency for eight types of appliances. Commercial appliances must meet these standards.

Results: The energy-efficiency ratios of room air conditioners was improved by $44 \%$ since 1970. The Commodities Labelling Law requires manufacturers to provide comparative energy labels to customers.

Reference: Energy Technical Service Center

Project Type: Standards and codes

Date: Ongoing

Affiliated/Future Projects: Comprehensive Energy Conservation Programs

Technology: Air conditioners, refrigerators, kitchen ranges, fans, ventilators, draft fans, motors, clothes dryers

Reference: ETSC, APEC questionnaire 


\begin{tabular}{|l|l|}
\hline Title: Energy and Resource Laboratories & Project Type: R\&D \\
\hdashline Organization: MOEA, ERL, ITRI & Date: Ongoing \\
\hdashline End-use Sector: All sectors & Affiliated/Future Projects: \\
\hdashline $\begin{array}{l}\text { Description: ERL is the primary organization } \\
\text { for developing and testing energy-efficient } \\
\text { products and renewable energy technologies. }\end{array}$ & Technology: All renewable energy and \\
ERL's core technologies include thermofluid \\
technology, electrotechnology, and combustion \\
technology. The organization also focuses on \\
bringing technologies to market.
\end{tabular}




\section{Hong Kong}

Hong Kong is a territory of about $1,000 \mathrm{~km}^{2}$ located off the southern coast of China. There is an efficient infrastructure, a modern communications network, and a population of about 5.8 million people. Hong Kong is the tenth largest trading entity in the world and has a developed financial services sector. It is and will remain, after 1997, a separate customs territory possessing full autonomy in the conduct of commercial activity and trade.

After a period of high economic growth for the years 1986 to 1988, Hong Kong experienced slow economic growth in 1989. The slowdown was largely cyclical, and the economy continued to grow steadily.

Hong Kong's gross domestic product (GDP) reached US\$82,731 million (at current market prices) in 1991 , up from US $\$ 2,698$ million in 1966. This represents an average annual growth rate of $6.2 \%$ for the period 1981 to 1991 . The GDP came primarily from the following market sectors: agriculture $(0 \%)$, manufacturing (17\%), and services (70\%). GDP rose $4.2 \%$ in 1991 . GDP growth of 5\% was forecast for 1992.

The average rate of inflation was $7.9 \%$ from 1981 to 1991 . Interest rates are expected to continue to stay low, in line with U.S. dollar interest rates.

In 1991, total exports totaled US $\$ 98,430$ million and imports totaled US $\$ 100,507$ million. Over the period 1981 to 1991, this represents an average annual growth rate for exports of $20.1 \%$ and an average annual growth rate for imports of $18.8 \%$.

Foreign trade is a prime component of Hong Kong's economy. In the first ten months of 1992, reexports rose sharply by $31 \%$ in value terms over the same period in 1991; however, domestic exports recorded a small increase of $2 \%$. Domestic exports to China surged further, while those to the United States recovered to show further growth. On the other hand, domestic exports to Germany, the United Kingdom, and Japan were on a downtrend.

Hong Kong manufactures textiles, electronics, watches, and toys. Tourism, shipping, banking, and insurance also provide significant strength to the economy.

In the first ten months of 1992 , imports grew by $24 \%$ to US $\$ 100.2$ billion, compared to the same period in 1991. China is Hong Kong's chief supplier and accounts for $37 \%$ of all traded goods; other key countries are Japan, Chinese Taipei and the United States. Imports consist of raw materials, consumer goods, capital goods, foodstuffs, and fuels.

Hong Kong serves as the most important entrepôt for indirect trade between China and the rest of the world. Eighty-six percent of re-exports consist of goods made in China or being imported to China. Re-exports rose $31 \%$ in the first ten months of 1992 compared to the same period a year earlier. The United States is the second largest destination of finished goods for re-export.

The Pacific Economic Outlook (1992 to 1993) predicted an economic growth rate of $6.4 \%$ for 1993. It cites the conclusion of the Sino-British Memorandum of Understanding on the construction of the new airport in September 1991 as a most significant factor supporting Hong Kong's faster economic growth. 


\section{Energy Use and Policy Issues}

Per capita energy consumption in Hong Kong equaled 1,908 kilograms of oil equivalent (kgoe) in 1991, up from $930 \mathrm{kgoe}$ in 1979. For the period of 1981 to 1991, primary energy consumption grew at an annual rate of $8 \%$.

Hong Kong depends on oil and gas as primary sources of energy. Its dependence on oil has fallen from almost $100 \%$ in 1981 to about $33 \%$ in 1991, while dependence on coal has risen from almost $0 \%$ in 1981 to about $67 \%$ in 1991 . Almost all the coal was used for electricity generation.

\section{Energy Efficiency and Conservation}

In 1991, the government of Hong Kong formed an Energy Efficiency Advisory Committee. The advisory committee gathered and studied data on energy consumption patterns in commercial sector buildings in Hong Kong. The findings of this work are preliminary in nature because of the limits of the data. Some of the more interesting and instructive findings follow:

- Although there has been a significant increase in electricity use in the sector, the increase primarily associated with the addition of new buildings rather than increased levels of use in existing buildings.

- Changing patterns of demand also are associated with changes in tenancy.

- Floor-by-floor data indicate enormous variations in energy consumption among floors.

- Air conditioning loads appear to average about $60 \%$ of total electric load (less in hotels); lighting and appliances account for an average of $36 \%$; and vertical transport accounts for an average of $8 \%$. (Data do not add to $100 \%$ because of statistical problems in estimating averages from samples of different sizes, etc.)

- Adjusting for climate, the average Hong Kong building does not compare favorably with similar buildings elsewhere.

The Committee notes that there is much work to be done to assemble better energy use data for Hong Kong and recommends that a multi-sector data base be developed, along with a set of predictive models, and a detailed set of technical and economic descriptions of energy-efficiency measures which could be implemented.

The Committee also began an energy-efficiency information campaign in the form of an Advisory Note on Energy Efficiency in Existing Commercial Buildings, which is directed at owners and managers of hotels and office and retail buildings. The note contains information, sometimes somewhat detailed, that could be of use in reducing energy use in commercial buildings. The following are the specific subjects:

- No-cost housekeeping

- $\quad$ Air conditioning

- Miscellaneous plant and equipment 
- Lifts and escalators

- $\quad$ Lighting and small power

- Envelope

- Water.

The rationale provided for energy-efficiency activities is threefold: (1) the reduction of reliance on imported fossil fuels, (2) the effect of combustion on the environment (including climate change), and (3) simple economics.

In addition to energy efficiency in buildings, the government examined waste-to-energy projects, landfill gas, and high-efficiency lighting for the new airport. China Light and Power Company is studying the use of ice storage, as well as electric vehicles, to improve its load factor.

\section{Bibliography}

Report from the Energy Data Working Group of the Energy Efficiency Advisory Committee; for the period April to October 1991

Advisory Note on Energy Efficiency in Existing Commercial Buildings in Hong Kong; Energy Efficiency Advisory Committee; September 1991

Departmental Review; Electrical and Mechanical Services Department; July 1991

Economic Trends Report-Hong Kong; U.S. Consulate General; December 1991

An Introduction to the Electrical and Mechanical Services Department

Internal data of Hong Kong government departments 


\begin{tabular}{l:l|}
\hline Title: Energy Efficiency Advisory Committee & Project Type: Policy assessment \\
\hdashline Organization: Energy Efficiency Advisory \\
Committee
\end{tabular}

\begin{tabular}{|c|c|}
\hline Title: Energy Data Working Group & Project Type: R\&D \\
\hline $\begin{array}{l}\text { Organization: Energy Efficiency Advisory } \\
\text { Committee }\end{array}$ & Date: April 1991; continuing \\
\hline $\begin{array}{l}\text { End-use Sector: Commercial, residential } \\
\text { buildings; industry }\end{array}$ & $\begin{array}{l}\text { Affiliated/Future Projects: The group } \\
\text { recommended continued research and the } \\
\text { development of a data base to track energy use. }\end{array}$ \\
\hline $\begin{array}{l}\text { Description: The objective of the group is to } \\
\text { collect data concerning the use of energy in } \\
\text { Hong Kong; priority is given to the commercial } \\
\text { sector. }\end{array}$ & Technology: Conservation \\
\hline $\begin{array}{l}\text { Results: The group collected data from hotels, } \\
\text { commercial buildings, property developers, and } \\
\text { the two power companies. The study found that } \\
\text { for commercial buildings electricity was used by } \\
\text { air conditioning ( } 60 \% \text { ), elevators }(15 \%) \text {, and } \\
\text { lighting ( } 36 \%) \text {. The average electricity } \\
\text { consumption is } 22.3 \mathrm{~kW} / \mathrm{m}^{2} \text { of gross floor area. }\end{array}$ & $\begin{array}{l}\text { Reference: Report from the Energy Data } \\
\text { Working Group }\end{array}$ \\
\hline
\end{tabular}




\begin{tabular}{|c|c|}
\hline Title: Existing Buildings Working Group & Project Type: Policy assessment \\
\hline $\begin{array}{l}\text { Organization: Energy Efficiency Advisory } \\
\text { Committee }\end{array}$ & Date: April 1991; continuing \\
\hline $\begin{array}{l}\text { End-use Sector: Commercial, residential } \\
\text { buildings; industry }\end{array}$ & $\begin{array}{l}\text { Affiliated/Future Projects: An advisory note } \\
\text { for residential buildings will soon be published. }\end{array}$ \\
\hline $\begin{array}{l}\text { Description: The group recommends measures } \\
\text { to improve energy efficiency of existing } \\
\text { buildings. It produces advisory notes for } \\
\text { building managers and promotes energy } \\
\text { efficiency in government and private buildings. }\end{array}$ & Technology: Conservation \\
\hline $\begin{array}{l}\text { Results: The Advisory Notes on Energy } \\
\text { Efficiency of Existing Commercial Buildings are } \\
\text { targeted at such specific groups as manu- } \\
\text { facturers, architects, engineers, and hotel } \\
\text { managers. Energy audits were conducted for } \\
\text { some government buildings and will be } \\
\text { extended to cover other government buildings. }\end{array}$ & $\begin{array}{l}\text { Reference: Advisory Notes on Existing } \\
\text { Commercial Buildings in Hong Kong }\end{array}$ \\
\hline
\end{tabular}

\begin{tabular}{|c|c|}
\hline Title: New Buildings Working Group & Project Type: Policy assessment \\
\hline $\begin{array}{l}\text { Organization: Energy Efficiency Advisory } \\
\text { Committee }\end{array}$ & Date: April 1991; continuing \\
\hline $\begin{array}{l}\text { End-use Sector: Commercial, residential } \\
\text { buildings; industry }\end{array}$ & $\begin{array}{l}\text { Affiliated/Future Projects: An advisory note } \\
\text { for residential buildings will soon be published. }\end{array}$ \\
\hline $\begin{array}{l}\text { Description: The group issues a Handbook on } \\
\text { Overall Thermal Transfer Value (OTTV) } \\
\text { calculation, which serves as a first step toward } \\
\text { the implementation of a comprehensive energy } \\
\text { code. An annual award scheme also will be } \\
\text { introduced for the most energy-efficient building } \\
\text { design in Hong Kong. }\end{array}$ & Technology: Conservation \\
\hline $\begin{array}{l}\text { Results: The implementation of OTTV control } \\
\text { is under consideration. }\end{array}$ & $\begin{array}{l}\text { Reference: The draft handbook on OTTV } \\
\text { calculation in buildings }\end{array}$ \\
\hline
\end{tabular}


Title: Educational Campaign Working Group

Organization: Energy Efficiency Advisory Committee

End-use Sector: All sectors (general public)

Description: The group will be launching a series of educational campaigns on energy efficiency starting February 1993.

Results: The public has been informed of the importance and the possible ways of saving energy through TV and radio API, bookmarks, and posters, which were distributed freely to the public during the educational campaign.
Project Type: Education/information

Date: April 1991; continuing

Affiliated/Future Projects: Establishment of an energy-efficiency display and information center and the introduction of an energyefficiency labeling system for electrical appliances

\section{Technology:}

Reference: Publicity materials of the educational campaign 


\section{Indonesia}

Indonesia is an island nation occupying more than 17,000 islands that span some $5,000 \mathrm{~km}$ from end to end. There are approximately 180 million people; $60 \%$ of the population lives on Java and more than 7 million live in the capital, Jakarta. Indonesia is a member of the Association of Southeast Asian Nations (ASEAN). Recently, Indonesia has been experiencing explosive economic growth and a rapid demand for energy.

Since independence in 1945, Indonesian history has been characterized by attempts to form a unified nation out of the diverse population. Since 1969, the New Order government designed and implemented a series of five-year plans. It has been quite successful and has met between $60 \%$ and $70 \%$ of its scheduled targets.

Indonesian gross domestic product (GDP) reached US $\$ 107,290$ million in 1990, up from US\$5,980 million in 1965. The GDP grew at an average annual growth rate of 5.5\% during 1980 to 1990 . The GDP came from the following market sectors: agriculture (22\%), industry (40\%), and services (38\%); within industry, manufacturing comprised $20 \%$ of GDP. The growth rate of GDP was $7.4 \%$ in 1989 and the estimated growth rate for 1990 was $7.1 \%$.

For the period of 1980 to 1990 , interest rates averaged $25.8 \%$. The inflation rate for 1989 and 1990 was $6.5 \%$.

A wide-ranging program of deregulation of the economy has been pursued since the early eighties. In particular, the banking sector and the financial sector have experienced an increase in activity. Investment spending has been exceptionally strong, increasing in real terms by $13.4 \%$ and $16.2 \%$ during 1989 and 1990, respectively. Government investment and Japanese investment were the largest contributors to the Indonesian economy.

In 1990, exports totaled US $\$ 25,553$ million and imports totaled US $\$ 21,837$ million. Over the period 1980 to 1990 , this represents an average annual growth rate for exports of $2.8 \%$ and an average annual growth rate for imports of $1.4 \%$. Recently, exports have exploded, experiencing growth of more than $27 \%$ during 1986 to 1990 . This trend slowed in 1990 (to a growth of less than $9 \%$ ) as a result of lower commodity prices and demand for manufactured goods.

For 1992, the Pacific Economic Outlook predicted continued growth of the Indonesian economy, with an increase in GDP of $6.6 \%$. Imports will continue their strong growth, and rising external debtservice payments will cause deficits of between 3\% and 5\% for 1991 and 1992. Private consumption will be the largest source of GDP growth, followed by private investment and government consumption. Interest rates are likely to stay high, and the exchange rate is likely to fall.

\section{Energy Use and Policy Issues}

In 1989, Indonesia's total energy output was 38.1 million tons of oil equivalent (Mtoe). This was supplied by oil $(68 \%)$, coal $(6.6 \%)$, hydro $(4.7 \%)$, and other sources $(20.7 \%)$. By 2000 , this is expected to grow to 86.3 Mtoe.

Per capita energy consumption equaled 272 kilograms of oil equivalent (kgoe) in 1990, up from $91 \mathrm{kgoe}$ in 1965 . For the period of 1980 to 1990 , energy consumption grew at an annual rate of $4.1 \%$. For the years 1965 to 1980 , energy consumption grew at an annual rate of $8.4 \%$. 
Indonesia is richly endowed with natural resources, including oil, gas, coal, hydropower, geothermal, and solar. In 1989, it ranked 13th among oil-producing nations, but the government has tried to shift domestic consumption away from petroleum.

Indonesia's oil reserves are estimated to be 70 billion barrels, and there are proven recoverable reserves of 8 to 10 billion barrels. In 1987, production equaled 1.7 million barrels per day. There are 80 trillion cubic feet ( 2.2 trillion cubic meters) of natural gas reserves, and most of these are independent of oil reserves. Indonesian coal reserves are believed to be 25 billion tons.

Electric power production in Indonesia has increased over 15 times in the past 20 years, from 563 megawatts (MW) in 1968 to 9,108 MW in 1990. Perusahaan Umum Listrik Negara's (PLN), the state electric utility, electricity generating capacity comes from the following sectors: hydropower $(21.6 \%)$, oil steam $(24.3 \%)$, coal steam (19\%), diesel (19\%), gas turbine (13.5\%), and geothermal $(1.5 \%)$.

Industrial users accounted for $70 \%$ of all electricity consumed. Despite rapid growth in the energy sector, Indonesia's per capita level of electricity consumption is 266 kilowatt-hours ( $\mathrm{kWh}$ ), and only $33 \%$ of the total population has access to electricity. Urban areas account for most of this consumption; Java consumes $80 \%$ of Indonesia's capacity. In rural areas, electricity reaches only $13 \%$ of the homes.

PLN expects electricity demand to increase fivefold (192,080 gigawatt-hours by 2003). To meet this demand, PLN has planned new coal, geothermal, hydropower, and nuclear power plants. This will add more than $6,000 \mathrm{MW}$ of new power to the Java-Bali system by 2003. The World Bank and Asian Development Bank are financing a large portion of these projects.

Several organizations are active in energy planning. The Ministry of Mines and Energy sets policy; PLN delivers electric power; Pertamina, the state oil company, administers petroleum production. Government committees also set pricing and formulate national energy plans. There are few private power companies.

The fifth five-year development plan, Replita V (1989 to 1993), sets primary objectives for improving the wealth of the entire population, sustaining high economic growth, and maintaining national stability.

The government of Indonesia has established a General Policy on Energy. The main policy objectives are the following:

- To guarantee supply of energy to meet domestic energy needs at affordable prices

- To make available exported energies (e. g., natural gas and oil)

- To develop new and renewable energy gradually to substitute for oil in the country's energy mix

- To use energy more efficiently and wisely

- To reduce the adverse impacts of excessive energy use to the environment. 
The main elements of this policy are the following:

- Intensification-increasing the exploration and surveying of resources

- Diversification-reducing dependence on oil by developing non-oil energy resources

- Conservation-using energy efficiently and wisely for the most productive use without sacrificing development objectives.

Energy conservation now is being promoted actively by government, in spite of per capita primary energy levels being below that of other countries. Conservation is viewed as being a cheap, quick, and a relatively painless way to reduce energy costs, stretch supply, and increase foreign exchange. Indonesia is now intensifying its energy conservation program for several reasons, including the following:

- Energy consumption per unit of GDP is higher than that of other countries in the Asian region and in developing countries.

- Based on studies, the potential for energy savings is still high.

- Energy conservation is needed to reduce the rapid growth in domestic demand.

Various conservation programs are operational, and more are being prepared. The programs consist of the following elements:

- Public awareness program using seminars, television, and contests for the design of energy-saving appliances

- Technical capability and skill program for operators of energy-consuming plants and equipment in the industrial, commercial, government, and household sectors

- Demonstration program to introduce new energy conservation technologies

- Research and development program to develop technology for energy management

- Program to encourage commitment to conservation by industrialists, building owners, and entrepreneurs.

In September 1991, Presidential Decree No. 43 was issued to instruct all government ministries and agencies to enforce energy conservation within their areas of responsibility. It is expected that the decree will become a milestone in the enhancement of energy conservation in Indonesia. In July 1992, the president launched a National Energy Conservation Campaign Program that marks the beginning of a vigorous national effort to become energy efficient.

New energy plans, having targets to the year 2000 , have been prepared. These programs include the same elements as past programs but have to achieve more definite objectives and concrete targets. For example, the target is to reduce domestic energy use by $17 \%$ by the year 2000 . In addition, qualitative and quantitative targets are set for each sector to achieve the national target by 2000 . Targets for reduction are $20 \%$ for industry and $15 \%$ for transport and household sectors. 
Targets have been set for the demonstration programs, in terms of the dissemination of prototypes in various sectors. Research and development program targets are set in terms of making energy-efficient equipment available in the domestic market. The government also has set targets for the establishment of a testing, standards, and labeling program.

\section{Energy Efficiency and Conservation}

Demand for energy in Indonesia has grown faster than supply, and the government has responded with various energy conservation initiatives. Energy conservation policies have been implemented since the third five-year plan (PELITA III), in 1979 to 1980. The program began with an educational campaign to inform the public and to create an understanding of the importance of energy conservation. Various media have been used in the campaign.

Conservation among government agencies was pursued through directives, beginning with Presidential Instruction No. 9 (1982).

In 1983, a program was begun that featured in-depth energy audits and analyses of energy use in selected energy-intensive industries (such as steel, cement, fertilizer, chemical, pulp, and paper), transportation power generation, and the commercial sector. The result of this work was the identification of potential energy savings in specific settings that could also serve as the basis for further policy and program development. Savings of 7 to 11 million barrels of oil were identified, based on 1983 consumption information. In addition, better energy management practices for specific industries were identified, as well as basic information needed to design energy-efficiency laws and regulations.

Currently, there are four main categories of energy-efficiency and conservation activities that are being implemented: (1) public information, (2) training and technical assistance on conservation measures, (3) regulation, and (4) establishing new institutions.

Energy audits have been conducted in industrial plants, ranging from energy-intensive industries to small- and medium-scale industries. These were financed through government funding or through technical assistance funds available from bilateral cooperation. In 1985, audits were conducted in cooperation with the French government that covered more than 130 industrial plants from a variety of sectors. A survey of urban household energy use was also conducted with the assistance of the ESMAP program of the World Bank. Potential energy savings were identified, and information of household appliance efficiency was prepared.

The industrial sector is the largest energy-consuming sector and has been a priority sector for the government programs. In August 1991, with the United Nations Industrial Development Organization (UNIDO), the European Economic Community (EEC), and Japan, the government completed a survey of small- and medium-scale industries. The goal of the survey was to prepare an energy conservation handbook for textile and steel industries. A demonstration is planned as a follow-up to this effort.

With the assistance of the United States Agency for International Development (USAID), the Directorate General for Electricity and New Energy (DGENE) has carried out a study on electricity demand-side management. The study is a preliminary effort, and additional study and implementation on the research is planned.

In 1987, Indonesia created a quasi-private corporation, Pt. Konservasi Energi Abadi (KONEBA), which provides technical assistance and consulting on various aspects of energy conservation. 
KONEBA has conducted energy audits on energy-intensive industries, medium-scale industries, and commercial buildings. KONEBA's activities cover jdentifying the potential for energy savings, training for industrial operators, and implementing energy-saving practices. Also, in cooperation with Gesselschaft fur Technische Zusammenarbeit (GTZ), KONEBA has conducted a study to identify cogeneration applications in industrial and commercial buildings and to promote such applications.

KONEBA has implemented some energy-saving measures on a shared savings basis. That is, the savings from implementing efficiency measures are divided between the client and KONEBA. Difficulties were encountered in the measurement of savings-a common problem. Many industrial sectors have shown interest in pursuing this arrangement, including textiles, cement, steel, fertilizer, and oil (seeking energy efficiency for the oil transport fleet).

The current information program features a National Team of Energy Conservation, which is responsible for a nationwide campaign program and for helping the government develop recommendations for policy measures for conservation. In addition, an Energy Conservation Campaign Team also has been set up to prepare the master plan for the campaign program that is expected to be carried out over a five-year period.

In rural areas, fuelwood use is a major concern, and the dissemination of energy-efficient stoves has begun in the last decade. Use of such stoves will protect the environment by reducing fuelwood consumption and will ease the work burden on women by reducing the time spent gathering and transporting fuelwood and making cooking more convenient. A number of efficient stoves have been developed, and various means of distributing them have been used. Distribution efforts were enhanced in Replita V, the fifth five-year development plan.

The Indonesian rural electrification program electrified 4,294 villages during Replita IV, bringing the total number of villages electrified with this program to 12,594 , as of 1989 . This program has developed several micro-hydroelectric plants, having a combined capacity of $75 \mathrm{MW}$, and also has used photovoltaics and diesel generators (52 MW total) to supply rural power. The government plans to continue these projects during Replita V-providing electrification for another 11,000 villages and 3 million consumers.

With the help of other countries, Indonesia has been studying and testing biomass, solar, wind, and mini-hydro energy technologies. An international cooperation project with Germany tested solar thermal, biomass, and PV systems. The project constructed several demonstration projects and studied applications and markets for renewable energy technologies. Indonesia also participated in the FINESSE (Financing Energy Services for Small-Scale Users) project.

\section{Bibliography}

Clean and Safe Energy Forever, Volume 1, Proceedings of the 1989 Congress of the International Solar Energy Society; September 1989

Indonesia: Asia-Pacific Energy Series Country Report; Widhyawan Prawiraatmadja, Nancy Yamaguchi, Kennon Breazeale; April 1991

Indonesia's Electric Power Sector; Economic Section American Embassy_Jakarta; January 1992

Renewable Energies Indonesia, REI; H. Noetzold, N. Suharta, L.M. Panggabean 


\begin{tabular}{|l|l|}
\hline $\begin{array}{l}\text { Title: Technical Guidance and Consulting for } \\
\text { Energy Conservation }\end{array}$ & Project Type: Policy assessment \\
\hdashline $\begin{array}{l}\text { Organization: Directorate General of } \\
\text { Electricity and New Energy }\end{array}$ & Date: 1987 \\
\hdashline End-use Sector: Industry & Affiliated/Future Projects: \\
\hdashline Description: The project audited 112 factories. & Technology: Conservation \\
\hdashline Results: & $\begin{array}{l}\text { Reference: ASEAN-EC Energy Conservation } \\
\text { Seminar }\end{array}$ \\
\hline
\end{tabular}

\begin{tabular}{l:l}
\hline Title: Decision and Implementation of Energy & Project Type: Policy assessment \\
Projects & \\
\hdashline Organization: BAKOREN (National Energy \\
Coordinating Board)
\end{tabular}

\begin{tabular}{|l|l|}
\hline Title: Energy Management Study of & Project Type: Audit \\
Padalarang Paper Mill & \\
\hdashline Organization: Puslitbank Fisika Terapan Lipi & Date: 1986 \\
\hdashline \begin{tabular}{c} 
End-use Sector: Industry (process energy) \\
\hdashline $\begin{array}{l}\text { Description: The audit concentrated on energy } \\
\text { consumption in the boiler house during pulp and }\end{array}$
\end{tabular} & $\begin{array}{l}\text { Technology: Conservation } \\
\text { paper manufacturing. }\end{array}$ \\
\hdashline $\begin{array}{l}\text { Results: The report recommended a shift in } \\
\text { electricity consumption to off-peak periods. }\end{array}$ & $\begin{array}{l}\text { Reference: ASEAN-EC Energy Conservation } \\
\text { Seminar }\end{array}$ \\
\hline
\end{tabular}




\begin{tabular}{|l|l|}
\hline Title: Energy Audit of Panghegar Hotel & Project Type: Audit \\
\hdashline Organization: Puslitbank Fisika Terapan Lipi & Date: 1986 \\
\hdashline End-use Sector: Commercial building & Affiliated/Future Projects: \\
\hdashline $\begin{array}{l}\text { Description: The audit studied energy } \\
\text { consumption at a hotel. It focused on air- } \\
\text { conditioning, lighting, steam, and boilers. }\end{array}$ & Technology: Conservation \\
\hdashline $\begin{array}{l}\text { Results: Conservation measures could save } \\
21 \% \text { of electricity and fuel costs. }\end{array}$ & $\begin{array}{l}\text { Reference: ASEAN-EC Energy Conservation } \\
\text { Seminar }\end{array}$ \\
\hline
\end{tabular}

\begin{tabular}{|l|l|}
\hline $\begin{array}{l}\text { Title: Experience with Photovoltaic Pump } \\
\text { Systems on Sumba }\end{array}$ & Project Type: Study/demonstration \\
\hdashline $\begin{array}{l}\text { Organization: BPP-Teknologi (Agency for the } \\
\text { Development and Application of Technology) }\end{array}$ & Date: 1981 to present \\
\hdashline End-use Sector: Renewable energy & $\begin{array}{l}\text { Affiliated/Future Projects: Solarvillage } \\
\text { Indonesia }\end{array}$ \\
\hdashline $\begin{array}{l}\text { Description: A German-Indonesian joint } \\
\text { venture assessed problems in pump system } \\
\text { designs and introducing solar design. }\end{array}$ & $\begin{array}{l}\text { Technology: Two pump systems to maximize } \\
\text { flow rate and efficiency }\end{array}$ \\
\hdashline $\begin{array}{l}\text { Results: Solar pump systems are operating } \\
\text { successfully in two locations. Improvement of } \\
\text { components will result in even greater } \\
\text { efficiency. }\end{array}$ & $\begin{array}{l}\text { Reference: Proceedings of the 1989 Congress } \\
\text { of International Solar Energy Society }\end{array}$ \\
\hline
\end{tabular}




\begin{tabular}{|c|c|}
\hline $\begin{array}{l}\text { Title: FINESSE (Financing Energy Services for } \\
\text { Small-Scale Energy Users) }\end{array}$ & Project Type: R\&D; tech transfer; study/demo \\
\hline $\begin{array}{l}\text { Organization: The World Bank, U.S. Depart- } \\
\text { ment of Energy, USAID, U.S. Environmental } \\
\text { Protection Agency, UNDP, Asian Development } \\
\text { Bank, Asian and Pacific Development Center, } \\
\text { Netherlands Ministry of Foreign Affairs }\end{array}$ & Date: FINESSE was launched in 1989. \\
\hline $\begin{array}{l}\text { End-use Sector: Commercial, residential } \\
\text { buildings }\end{array}$ & $\begin{array}{l}\text { Affiliated/Future Projects: Sukitani PV } \\
\text { Electrification }\end{array}$ \\
\hline $\begin{array}{l}\text { Description: The FINESSE Project was } \\
\text { launched to conduct market studies, promote the } \\
\text { manufacture of energy-efficient light bulbs and } \\
\text { appliances, examine the institutional } \\
\text { environment for alternative energy projects, } \\
\text { establish ASEAN project opportunities, establish } \\
\text { a multidonor feasibility fund, and host } \\
\text { international conferences. }\end{array}$ & Technology: All renewable energy \\
\hline $\begin{array}{l}\text { Results: FINESSE completed market studies } \\
\text { on Malaysia, the Philippines, Indonesia, and } \\
\text { Thailand. The studies identified project } \\
\text { opportunities for renewable energy. }\end{array}$ & $\begin{array}{l}\text { Reference: FINESSE Country Market Studies, } \\
\text { FINESSE Report. }\end{array}$ \\
\hline
\end{tabular}




\section{Japan}

Japan occupies an island chain in the western part of the Pacific Ocean, covering a total land area of some $377,700 \mathrm{~km}^{2}$. Approximately 124 million people live in Japan.

Japan has become one of the world's greatest economic powers, and its growth has astonished experts and laymen alike. Today, the Japanese economy remains strong, and Japan is the largest lending nation in the world.

Japan's gross domestic product (GDP) was US $\$ 2,977,725$ million in 1990 , up from US $\$ 1,067,294$ million in 1980 . In 1991 , GDP rose $4.4 \%$ and reached US $\$ 3,373,824$ million. This represents an average annual growth rate of $4.1 \%$ during 1980 to 1990 . The GDP came from the following market sectors: agriculture (3\%), industry (42\%), and services (56\%); within industry, manufacturing comprised 29\%. The GDP rose 5.8\% in 1990 and a GDP growth of $3 \%$ was predicted for 1991.

In 1991, exports totaled US $\$ 314,525$ million and imports totaled US $\$ 236,737$ million. Over the period 1980 to 1990, this represents an average annual growth rate for exports of $8.3 \%$ and an average annual growth rate for imports of $5.3 \%$.

The average rate of inflation was $1.7 \%$ from 1980 to 1990 ; and for 1990 , the official discount rate was $3.25 \%$ (as of July 28,1992 ).

Although growth of exports has decelerated since 1990, the Pacific Economic Outlook predicts a gross national product (GNP) growth rate for Japan of 4.3\% in 1992.

\section{Energy Use and Policy Issues}

Per capita energy consumption equaled 3,635 kilograms of oil equivalent (kgoe) in 1990, up from 1,563 kgoe in 1965 . For 1980 to 1990 , energy consumption grew at an annual rate of $4.4 \%$. For the years between 1965 and 1980, energy consumption grew at an annual rate of 5.9\%.

Japan depends greatly on imported energy. In 1991, it imported $84 \%$ of the entire energy supply. The total energy supply in 1991 consisted of oil (57\%), coal (17\%), liquefied natural gas (11\%), and hydro, geothermal, and renewables (6\%).

Ten power companies supply electricity to Japan and have a generating capacity of 152,715 megawatts (MW). In 1991, there were 69,374,000 customers using 679,237 gigawatt-hours.

Japanese energy policies basically treat the period up to the beginning of the twenty-first century as a critical time to start to overcome pressing issues. Energy policies in accordance with the following goals are expected to be adopted immediately:

- To respond to an expansion, diversification, and sophistication of energy needs prompted by the pursuit of greater leisure time in everyday life; at the same time, to control as much as possible an increase in energy demand by making all-out efforts to use energy efficiently 
- To take into account the aim to secure global energy security and continue working toward lowering the dependence on oil; at the same time, to realize a supply structure with greater dependence on nonfossil energy (nuclear energy; new, renewable energies)

- To actively carry out policy coordination and cooperation in the field of energy. During that time, to broaden the focus to all countries in the world and realize comprehensive and effective international cooperation by expanding activities to energy-related fields in general, without being limited to details and individual fields.

The conditions surrounding energy will grow more complex; resource and environmental constraints are issues facing the world as well as all Japanese people.

Since the sum total of everyday life and economic activities constitutes the cause of energy problems (i. e., the manifestation of resource and environmental constraints), Japanese people are expected to tackle these problems together. In order to deepen this awareness, it is considered necessary to hold countrywide informal discussions and various publicity activities concerning energy problems. It also is essential to encourage, on a national scale, discussions and studies on human activities, industrial activities, and social and industrial systems, as well as on the proper use of land marked by overconcentration in Tokyo.

\section{Energy Efficiency and Conservation}

1. In the past, Japan has

a. Appropriately applied the Law Concerning the Rational Use of Energy (establishment and announcement of standards concerning plant energy management, heat insulation of homes, fuel consumption of automobiles)

b. Promoted energy conservation-related technology (Moonlight Project) and extended tax benefit incentives and financial assistance to investment in energy-saving plant and equipment

c. Undertaken education and publicity activities concerning energy conservation via publicity activities by government and the Energy Conservation Center (ECC). As a result, Japan's energy consumption to unit of gross national product has improved roughly $37 \%$ since the first oil crisis in 1973.

2. In recent years, however, energy demand has risen, and the rate of improvement of energy use is slowing down. This is attributed to changes in lifestyle driven by intensifying production activities that are fueled by booming business conditions and the pursuit of "more leisure time." Meanwhile, the necessity for energy conservation is mounting rapidly, as solutions to global environmental problems such as global warming are sought.

As such, the projected level of energy demand (average annual growth from fiscal years 1989 to 2000: $1.4 \%$ ), which is a precondition of the Oil-Alternative Energy Supply Targets determined by the cabinet in October 1991, must be achieved. Additionally, the Action Program for Global Warming, which aims at stabilizing per capita $\mathrm{CO}_{2}$ emissions roughly at 1990 levels after the year 2000 , must be realized. For this purpose, it would be considered essential to lower the growth in energy demand as the year 2000 draws near. 
3. Global warming is emerging as a problem shared by mankind, and there is concern that the longterm supply and demand conditions of energy will tighten. Against this background, comprehensive energy conservation measures must be promptly implemented to realize sustained economic growth, stability of energy supply and demand, and global environmental protection.

4. Near-term issues include:

a. Achieving the goal to stabilize Japan's per capita $\mathrm{CO}_{2}$ emissions roughly at 1990 levels after the year 2000, as set forth in the Action Program for Global Warming (determined at the cabinet meeting in October 1990)

b. Achieving the Oil-Alternative Energy Supply Targets that are indispensable for attaining the above objective in the year 2000 , on both the supply and demand front.

5. Japan plans to achieve the levels of energy supply specified in the supply targets by the year 2000 by making maximal government efforts in the future by introducing such nonfossil energy as nuclear energy.

6. Some sources estimate that if additional energy conservation policies are not implemented, demand (420 to 430 million kiloliters $(\mathrm{kL})$ per year) will largely surpass the energy demand level (oil equivalent of 391 million $\mathrm{kL}$ per year on a final consumption basis). This demand level is a precondition of the supply targets in the year 2000, based on the growth in energy demand of recent years. Thus, drastic energy conservation measures are expected to be implemented.

7. Under these circumstances, the Energy-Subcommittee of the Advisory Committees for Energy has been meeting since September 1991. The subcommittee is undertaking studies to drastically reinforce energy conservation policies. At the same time, the importance of energy conservation measures was pointed out as an issue to be dealt with swiftly in the near term at the joint meeting of the Industrial Structure Council, Agency of Natural Resources and Energy, and the Industrial Technology Council, held in June 1992.

The Ministry of International Trade and Industry (MTTI) and the Agency of Natural Resources and Energy are committed to treat the promotion of comprehensive energy conservation policies as the foremost issue of MITI's near-term policies. In order to smoothly undertake this effort, MITI is

a. Developing a legal framework for the promotion of comprehensive measures

b. Stepping up policy measures by drastically reinforcing financial assistance measures in the budget for fiscal year 1993.

8. MITI also has been promoting technical development to contribute to energy conservation and new energy technologies. Since 1974, the Agency of Industrial Science and Technology of MITI has been promoting the Sunshine Project and promoting technical development to contribute to the development of such recycled energy as solar energy and wind power energy and such oilalternative energies as geothermal power and coal gasification. 
9. Since 1978, the Agency of Industrial Science and Technology of MITI has been promoting the Moonlight Project, a research and development project aimed at saving Japan's energy and rationalizing energy policy. The budget for FY 1990 ( $¥ 11,902$ million) covers the following projects:

a. Five large-scale energy conservation projects, including battery storage, fuel cells, heat pumps, superconductors, and ceramic turbines

b. Eleven basic-technology research projects at national research institutes. Projects include noncontact thermometry, Diesel-Brayton combined cycle engines, hydride performance membranes, multifuel Otto cycle engines, high lithium ion conductivity, alkali metal thermoelectric converters, aluminum scrap refining technology, new ceramics, and binary fluid power generation

c. International Cooperation Projects through the International Energy Agency (IEA), including research on heat pumps and thermofluids. Bilateral cooperation with France, the United States, Thailand, and certain other countries

d. Evaluation methods and policy for energy conservation technologies

e. Standards for energy efficiency. The standards fall into three categories: standards for testing and terminology, standards for high-efficiency products, and standards for resource conserving products.

f. Conditional loans to private enterprise projects "which must focus on developing or improving equipment to promote use of alternative energy or more efficient use of energy."

10. Under the auspices of MITI, the New Energy and Industrial Technology Development Organization (NEDO) - a semigovernmental organization-is carrying out a large-scale technical energy research and development project under the Moonlight Project. NEDO also is exploring new energy development, including development of technology for utilizing such unused energy as waste heat from plants.

11. As an international activity, NEDO is undertaking a joint project with Thailand on phosphoric acid fuel cells. With regard to solar batteries, NEDO is conducting a feasibility study with Australia and advancing joint demonstration development with Thailand, Malaysia, Nepal, and Mongolia. It also is carrying out a joint water supply project with Indonesia that uses solar batteries. In addition, NEDO is conducting a feasibility study on ethanol production (using tapioca) and mild gasification (using peat). In 1992, as part of international cooperation in industrial technology, NEDO started the development of the high-efficiency combustion technology for heavy oil, as well as conservation technology for electric furnaces during the steelmaking.

NEDO has sent specialists to countries belonging to the Association of Southeast Asian Nations (ASEAN) and has held seminars and exchanged information on new energy technologies with other countries. As a result, an international project for joint research and development of new energy technologies and energy conservation was proposed.

12. Two agencies, the Overseas Economic Cooperation Fund and the Japanese International Cooperation Agency (JICA), administer Japan's official development-assistance funds for 
international projects. These projects include energy conservation projects and renewable energy projects. For example, JICA funded rural electrification in Thailand.

13. Japanese policymakers endorse market promotion measures to accelerate domestic diffusion of new technologies. These promotions can include low-interest financing, tax measures, and leasing. Consumers of solar heating and cooling are eligible for low-cost loans, and the Solar System Development Fund involves a solar fund financed by MITI and private companies.

14. ECC provides support and leadership for the energy conservation activities in Japan. The center holds the National Convention for the Promotion of Energy Conservation and publishes literature on energy conservation. One publication, Successful Cases of Energy Conservation, details conservation activities in industry and provides references for energy managers.

15. The IEA carries out numerous conservation projects under international agreements. Japan participates in research projects examining working fluids, absorption heat pumps, and heat pump systems. In 1990, Japan participated in the IEA's Heat Pump Center, and they also have participated in the Center for the Analysis and Dissemination of Demonstrated Energy Technologies, IEA (CADDET). Technical information provided CADDET by Japan includes energy-efficient high rises, energy-efficient gymnasiums, and fluidized bed combustion at a paper mill.

\section{National Energy Laboratories}

Japan funds most of the renewable energy and conservation projects through the Sunshine Project and the Moonlight Project. Most of the actual research occurs at universities or national laboratories. The Electrotechnical Laboratory has 700 employees and 250 visiting researchers from industry. One hundred of these employees examine energy-related subjects, including photovoltaics and fuel cells. The Mechanical Engineering Laboratory examines wind turbines and hydrogen energy.

\section{Bibliography}

'89 Successful Cases of Energy Conservation; The Energy Conservation Center

Fiscal Year 1990 Annual Report: Geothermal Energy Survey and Technology; New Energy and Industrial Technology Development Organization

Fiscal Year 1990 Annual Report. Solar Energy Technology; New Energy and Industrial Technology Development Organization

FY1991 Research and Development Projects [1]; New Energy and Industrial Technology Development Organization; April 1991

NEDO Creates New Energy; New Energy and Industrial Technology Development Organization

Sunshine Journal, R\&D on New Energy and Energy Conservation Technology in Japan, No. 3 1992;

Sunshine Project Promotion Headquarters, Agency of Industrial Science and Technology; March 1992

The Sunshine Project for Establishing Clean, New Energy Technology; Office of Sunshine Project, Agency of Industrial Science and Technology; March 1991 
The Twenty-First Century Energy Vision-Entering the Multiple Energy Era; Ministry of International Trade and Industry

The Moonlight Project: Developing New Technologies for Energy Conservation; March 1990 


\begin{tabular}{|c|c|}
\hline $\begin{array}{l}\text { Title: Reduction in Power Consumption by } \\
\text { Forced-Air Blower Systems in Coke Oven }\end{array}$ & Project Type: Study/demonstration \\
\hline Organization: Nippon Steel (Kimitsu plant) & Date: $7 / 87$ to $3 / 88$ \\
\hline End-use Sector: Industry (steel) & Affiliated/Future Projects: None \\
\hline $\begin{array}{l}\text { Description: Study and demonstration to } \\
\text { reduce power consumption of a forced-air } \\
\text { blower system that supplies air for combustion } \\
\text { of fuel gas in coke oven batteries. }\end{array}$ & $\begin{array}{l}\text { Technology: Improved combustion control } \\
\text { scheme and various combinations of blower and } \\
\text { natural draft }\end{array}$ \\
\hline $\begin{array}{l}\text { Results: Reduction in power consumption: } 6 \\
\text { million kWh/yr. Cost savings: } 48 \text { million } \\
\text { yen/yr. Ratio of energy savings: } 58 \% \text {. }\end{array}$ & $\begin{array}{l}\text { Reference: } 1989 \text { Successful Cases of Energy } \\
\text { Conservation }\end{array}$ \\
\hline
\end{tabular}

\begin{tabular}{|c|c|}
\hline $\begin{array}{l}\text { Title: Electric Power Saving for Blast Furnace } \\
\text { Cooling Facilities }\end{array}$ & Project Type: Study/demonstration \\
\hline $\begin{array}{l}\text { Organization: Sumitomo Metal Industry Co., } \\
\text { Ltd. (Kokura Steelworks) }\end{array}$ & Date: 1987 \\
\hline End-use Sector: Industry (steelworks) & Affiliated/Future Projects: None \\
\hline $\begin{array}{l}\text { Description: Study and demonstration to find } \\
\text { ways to cut back on energy consumption in the } \\
\text { iron and steel industry. }\end{array}$ & $\begin{array}{l}\text { Technology: Rationalization of water flow } \\
\text { volume; reduction of cooling box water flow } \\
\text { volume; series flow of cooling water for tuyere } \\
\text { nose and body; modification of slag granulator }\end{array}$ \\
\hline $\begin{array}{l}\text { Results: Power consumption reduced from } \\
1,222 \mathrm{kWh} / \mathrm{h} \text { to } 805 \mathrm{kWh} / \mathrm{h} \text {. }\end{array}$ & $\begin{array}{l}\text { Reference: } 1989 \text { Successful Cases of Energy } \\
\text { Conservation }\end{array}$ \\
\hline
\end{tabular}




\begin{tabular}{|c|c|}
\hline $\begin{array}{l}\text { Title: Low-Cost Control of Fan Pump by } \\
\text { Inverters }\end{array}$ & Project Type: Study/demonstration \\
\hline $\begin{array}{l}\text { Organization: Toyoda Gosei Co., LTD } \\
\text { (Production Engineering Department) }\end{array}$ & Date: 1987 \\
\hline $\begin{array}{l}\text { End-use Sector: Industry (production } \\
\text { engineering) }\end{array}$ & Affiliated/Future Projects: None \\
\hline $\begin{array}{l}\text { Description: Study and demonstration to } \\
\text { develop a control system that facilitates low-cost } \\
\text { control, by classifying fans and pumps into four } \\
\text { control groups according to capacity and } \\
\text { purpose, for lowering power consumption. }\end{array}$ & $\begin{array}{l}\text { Technology: A control system that facilitates } \\
\text { control by using pump discharge side water } \\
\text { temperature and discharge pressure rather than } \\
\text { using constant discharge pressure control } \\
\text { combined with temperature control valves }\end{array}$ \\
\hline $\begin{array}{l}\text { Results: Power consumption was reduced, the } \\
\text { surging of fans was prevented, room noise was } \\
\text { decreased, and the combustion control area of } \\
\text { the burners was expanded. }\end{array}$ & $\begin{array}{l}\text { Reference: } 1989 \text { Successful Cases of Energy } \\
\text { Conservation }\end{array}$ \\
\hline $\begin{array}{l}\text { Title: Energy-Saving Activity on Utility } \\
\text { Installation }\end{array}$ & Project Type: Study/demonstration \\
\hline $\begin{array}{l}\text { Organization: Ohtsu Tire Co., Ltd. (Izumi- } \\
\text { Ohtsu Factory) }\end{array}$ & Date: 1982 to 1988 \\
\hline $\begin{array}{l}\text { End-use Sector: Industry (prime power } \\
\text { installations) }\end{array}$ & Affiliated/Future Projects: None \\
\hline $\begin{array}{l}\text { Description: Study of the energy-saving } \\
\text { activities related to the so-called prime power } \\
\text { installations for generating and supplying } \\
\text { utilities, including boilers, compressors, } \\
\text { vulcanizers, and coolers. This study applied to } \\
\text { the production of tires and tubes. }\end{array}$ & $\begin{array}{l}\text { Technology: Small-capacity pump to reduce } \\
\text { pump power consumption of softened water } \\
\text { supply to boiler; three-way valves installed on } \\
\text { heat exchanger recovery tubes to reduce power } \\
\text { of waste heat recovery pump; ventilation duct } \\
\text { mounted on compressor motor for discharging } \\
\text { the heat from the motor to the outside to reduce } \\
\text { power consumption; strainer installed on warm } \\
\text { water tank suction tube to remove rubber dust } \\
\text { and to increase pump efficiency }\end{array}$ \\
\hline $\begin{array}{l}\text { Results: Unit improvement from } 1982 \text { to } 1987 \\
\text { was } 11 \% \text {, compared to } 10 \% \text { target; achievement } \\
\text { ratio } 110 \% \text {. }\end{array}$ & $\begin{array}{l}\text { Reference: } 1989 \text { Successful Cases of Energy } \\
\text { Conservation }\end{array}$ \\
\hline
\end{tabular}




\begin{tabular}{|c|c|}
\hline $\begin{array}{l}\text { Title: Improved Efficiency for Raw Oil } \\
\text { Heating Furnace }\end{array}$ & Project Type: Study/demonstration \\
\hline $\begin{array}{l}\text { Organization: Idemitu Kosan Co. (Chiba } \\
\text { Refinery) }\end{array}$ & Date: 1988 \\
\hline End-use Sector: Industry (oil refining) & Affiliated/Future Projects: None \\
\hline $\begin{array}{l}\text { Description: Study and demonstration to } \\
\text { reduce the amount of } \mathrm{O}_{2} \text { and improve the } \\
\text { overall performance of raw oil heating furnace, } \\
\text { a part of a residual oil desulfurization system. }\end{array}$ & $\begin{array}{l}\text { Technology: Modification of equipment and } \\
\text { procedures; improved damper blades reduced } \\
\text { number of ignition burners. }\end{array}$ \\
\hline $\begin{array}{l}\text { Results: Reduced } \mathrm{O}_{2} \text { concentration in flue gas } \\
\text { from } 5.2 \% \text { to } 2.5 \% \text {, saving } 490 \mathrm{~kL} / \mathrm{yr} \text { of fuel } \\
\text { oil. }\end{array}$ & $\begin{array}{l}\text { Reference: } 1989 \text { Successful Cases of Energy } \\
\text { Conservation }\end{array}$ \\
\hline
\end{tabular}

\begin{tabular}{|c|c|}
\hline $\begin{array}{l}\text { Title: Energy-saving Measures for Pretreatment } \\
\text { Drying Oven }\end{array}$ & Project Type: Study/demonstration \\
\hline $\begin{array}{l}\text { Organization: Nissan Automobile Co. } \\
\text { (Murayama Plant) }\end{array}$ & Date: 1988 \\
\hline $\begin{array}{l}\text { End-use Sector: Industry (automobile } \\
\text { manufacturing) }\end{array}$ & Affiliated/Future Projects: None \\
\hline $\begin{array}{l}\text { Description: Study and demonstration to find } \\
\text { ways to cut energy consumed in pretreatment } \\
\text { drying oven for automobile body coatings. } \\
\text { Results will be applied to other drying ovens. }\end{array}$ & $\begin{array}{l}\text { Technology: Improved equipment and mode of } \\
\text { operation by reducing oven volume, moving air } \\
\text { outlets, reducing size of exit and entrance to } \\
\text { reduce air leakage, and installing deflector. }\end{array}$ \\
\hline $\begin{array}{l}\text { Results: Reduced annual fuel gas consumption } \\
\text { by } 40 \%\left(252,000 \mathrm{~m}^{3}\right) \text {. Reduced annual } \\
\text { electricity consumption by } 32 \% \text { ( } 55 \mathrm{MWh}) \text {. }\end{array}$ & $\begin{array}{l}\text { Reference: } 1989 \text { Successful Cases of Energy } \\
\text { Conservation }\end{array}$ \\
\hline
\end{tabular}


Title: Energy Conservation by Improvement of Furnace Control Method

Organization: Nippon Mining Co., Ltd. (Mizushima Oil Refinery)

End-use Sector: Industry (oil refineries)

Description: Study to find out how much excess $\mathrm{O}_{2}$ can be reduced from current level of $2.5 \%$ and whether continuous stable and efficient operations are possible.

Results: Fuel savings was $1.2 \% ; \mathrm{O}_{2}$ level was lowered to $1.5 \%$.
Project Type: Study/demonstration

Date: 1987 to 1988

Affiliated/Future Projects: None

Technology: Use of a micro-computer for a control system to control automatically and simultaneously excess $\mathrm{O}_{2}$ and the furnace outlet temperature.

Reference: 1989 Successful Cases of Energy Conservation

\begin{tabular}{|c|c|}
\hline $\begin{array}{l}\text { Title: Reduction of Power Consumption } \\
\text { through the Use of Low-Temperature Heat from } \\
\text { Distilling Tower }\end{array}$ & Project Type: Study/demonstration \\
\hline $\begin{array}{l}\text { Organization: Idemitsu Kosan Co., LTD } \\
\text { (Aichi Refinery) }\end{array}$ & Date: 1987 \\
\hline End-use Sector: Industry (oil refineries) & Affiliated/Future Projects: None \\
\hline $\begin{array}{l}\text { Description: Study and demonstration to } \\
\text { improve or revise the design of residue fluid } \\
\text { catalytic cracking to make the most efficient use } \\
\text { of energy by recovering waste heat from low- } \\
\text { temperature fluid and increasing recovery of } \\
\text { liquid petroleum gas. }\end{array}$ & $\begin{array}{l}\text { Technology: Chiller system using lithium bro- } \\
\text { mide that can provide low-temperature fluid at } \\
\text { nearly constant temperature throughout a year, } \\
\text { distributed control system (DCS), and AI } \\
\text { (artificial intelligence); combined computer } \\
\text { control with conventional control for labor } \\
\text { economy and safer operation. }\end{array}$ \\
\hline Results: LPG recovered: 4,400 to & $\begin{array}{l}\text { Reference: } 1989 \text { Successful Cases of Energy } \\
\text { Conservation }\end{array}$ \\
\hline
\end{tabular}




\begin{tabular}{|c|c|}
\hline $\begin{array}{l}\text { Title: Energy-saving Measures in Town Gas } \\
\text { Works }\end{array}$ & Project Type: Study/demonstration \\
\hline $\begin{array}{l}\text { Organization: Osaka Gas Company, LTD } \\
\text { (Senboku Works I) }\end{array}$ & Date: 1987 \\
\hline End-use Sector: Industry (factories) & Affiliated/Future Projects: None \\
\hline $\begin{array}{l}\text { Description: Study and demonstration to obtain } \\
\text { an energy-saving factory in which energy is } \\
\text { utilized most effectively. }\end{array}$ & $\begin{array}{l}\text { Technology: Liquid natural gas vaporizer using } \\
\text { hot water to cut down power by means of } \\
\text { liquid/gas quality control system; brine } \\
\text { preheater to cut down refrigerator power; boiler } \\
\text { to supply steam to neighboring businesses }\end{array}$ \\
\hline $\begin{array}{l}\text { Results: Power reduced to } 700 \times 10^{4} \mathrm{kWh} \\
\text { annually. }\end{array}$ & $\begin{array}{l}\text { Reference: } 1989 \text { Successful Cases of Energy } \\
\text { Conservation }\end{array}$ \\
\hline
\end{tabular}

Title: Furnace Control Methods for Energy Conservation

Organization: Mizushima Oil Refinery, Nippon Mining Company

End-use Sector: Industry

Description: The factory stabilized $\mathrm{O}_{2}$ in the furnace using computer controls.

Results: The plant saved eight million yen/yr.

Project Type: Study/demonstration

Date: 1988

Affiliated/Future Projects:

Technology: Conservation

Reference: 1989 Successful Cases of Energy Conservation 


\begin{tabular}{|c|c|}
\hline $\begin{array}{l}\text { Title: Recycling Exhaust Air Pressure and } \\
\text { Saving Hot Water/Electricity }\end{array}$ & Project Type: Study/demonstration \\
\hline Organization: Nippondenso Co. (Anjo Plant) & Date: $2 / 87$ to $7 / 88$ \\
\hline $\begin{array}{l}\text { End-use Sector: Industry (manufacture of } \\
\text { electrical parts, starters, alternators) }\end{array}$ & Affiliated/Future Projects: None \\
\hline $\begin{array}{l}\text { Description: (1) Study and demonstration to } \\
\text { reduce energy wasted by continuously blowing } \\
\text { air to clean up afterwelding. (2) Study and } \\
\text { demonstration to reduce flow rate of hot water } \\
\text { used for washing work-in-progress. (3) Study } \\
\text { and demonstration to automate turning } \\
\text { fluorescent lights on and off. }\end{array}$ & $\begin{array}{l}\text { Technology: (1) Adapted cylinders and } \\
\text { recycled exhaust air from cylinders; (2) tested } \\
\text { lower flow rate and found it was satisfactory; } \\
\text { (3) installed circuit to turn lights on and off } \\
\text { when winding machine turned on and off. }\end{array}$ \\
\hline $\begin{array}{l}\text { Results: (1) Reduced cost of welding cleanup } \\
\text { from } 850,000 \text { yen/yr to } 10,000 \text { yen/yr on one } \\
\text { production line; expanded to others for total } \\
\text { savings of } 2.2 \text { million yen/yr. (2) Reduced } \\
\text { flow rate of hot water from } 420 \mathrm{~L} / \mathrm{hr} \text { to } 90 \mathrm{~L} / \mathrm{hr} \text {. } \\
\text { (3) Reduced number of lights from } 49 \text { to } 25 \text {. }\end{array}$ & $\begin{array}{l}\text { Reference: } 1989 \text { Successful Cases of Energy } \\
\text { Conservation }\end{array}$ \\
\hline
\end{tabular}

\begin{tabular}{|c|c|}
\hline $\begin{array}{l}\text { Title: Energy-saving through the Use of a } \\
\text { Highly Efficient and Inexpensive Priming } \\
\text { Device }\end{array}$ & Project Type: Study/demonstration \\
\hline $\begin{array}{l}\text { Organization: Toyota Motor Corp. (Plant } \\
\text { Engineering Division) }\end{array}$ & Date: 1987 to 1988 \\
\hline $\begin{array}{l}\text { End-use Sector: Industry (automobile } \\
\text { manufacturing) }\end{array}$ & Affiliated/Future Projects: None \\
\hline $\begin{array}{l}\text { Description: Study and demonstration to } \\
\text { eliminate wasteful energy consumption, during } \\
\text { the break between auto manufacturer work } \\
\text { shifts, by using an inexpensive priming device } \\
\text { to minimize energy consumption. }\end{array}$ & $\begin{array}{l}\text { Technology: Supercharger for an automobile } \\
\text { engine that functions like a commercially } \\
\text { available vacuum pump; therefore, it is a viable } \\
\text { substitute for a vacuum pump. }\end{array}$ \\
\hline $\begin{array}{l}\text { Results: Running cost was decreased by } 47 \% \text {; } \\
\text { equipment cost was reduced. }\end{array}$ & $\begin{array}{l}\text { Reference: } 1989 \text { Successful Cases of Energy } \\
\text { Conservation }\end{array}$ \\
\hline
\end{tabular}




\begin{tabular}{|c|c|}
\hline $\begin{array}{l}\text { Title: Fluidized Bed Combustion Boiler for } \\
\text { Power Generation }\end{array}$ & Project Type: Study/demonstration \\
\hline Organization: Tomakomai Mill Oji Paper Co. & Date: 1985 \\
\hline End-use Sector: Industry & Affiliated/Future Projects: None \\
\hline $\begin{array}{l}\text { Description: Study of a fluidized bed } \\
\text { combustion boiler that uses pulp sludge and } \\
\text { bark as fuel. }\end{array}$ & $\begin{array}{l}\text { Technology: New fluidized bed uses the } \\
\text { maximum possible heat energy in sludge and } \\
\text { bark to produce steam for generating electricity } \\
\text { while disposing of the ashes. A water scrubber } \\
\text { and an electrostatic precipitation reduced } \mathrm{SO}_{\mathrm{x}} \\
\text { and fly ash emissions. }\end{array}$ \\
\hline $\begin{array}{l}\text { Results: Savings were } 10,300 \mathrm{~kW} \text {; payback } \\
\text { period was } 2 \text { years. }\end{array}$ & Reference: IEA CADDET \\
\hline
\end{tabular}

\begin{tabular}{|c|c|}
\hline Title: Photovoltaic Power System & Project Type: R\&D \\
\hline $\begin{array}{l}\text { Organization: New Energy and Industrial } \\
\text { Technology Development Organization (NEDO) }\end{array}$ & Date: 1983 \\
\hline $\begin{array}{l}\text { End-use Sector: Industry (manufacturing } \\
\text { systems) }\end{array}$ & Affiliated/Future Projects: None \\
\hline $\begin{array}{l}\text { Description: Study to develop a photovoltaic } \\
\text { power system for use in the manufacturing } \\
\text { sector. }\end{array}$ & $\begin{array}{l}\text { Technology: } 500-\mathrm{kW} / \mathrm{yr} \text { manufacturing system } \\
\text { using solar cells }\end{array}$ \\
\hline $\begin{array}{l}\text { Results: Operational trials of system have been } \\
\text { in progress since FY } 1983 .\end{array}$ & Reference: The Sunshine Project \\
\hline
\end{tabular}

\section{Title: Ceramic Gas Turbine Project}

Organization: Japan's Ministry of International Trade and Industry's Agency of Industrial Science and Technology

End-use Sector: Industry (cogeneration and power generation)

Description: To develop 300-kW ceramic gas turbines applicable to cogeneration and mobile power generation systems to make these systems more energy efficient, compact, and adaptable to a variety of fuels.

Results: Still under study.
Project Type: R\&D

Date: FY 1988 to 1996

Affiliated/Future Projects: None

Technology: Bonding/joining of components made of highly heat-resistant ceramics; development of full-scale ceramic components; ceramic gas turbine engine system.

Reference: The Moonlight Project 


\begin{tabular}{|c|c|}
\hline $\begin{array}{l}\text { Title: Super Heat Pump Energy Accumulation } \\
\text { System }\end{array}$ & Project Type: R\&D \\
\hline $\begin{array}{l}\text { Organization: Japan's Ministry of International } \\
\text { Trade and Industry's Agency of Industrial } \\
\text { Science and Technology }\end{array}$ & Date: 1984 to 1992 \\
\hline End-use Sector: Industry (air conditioning) & Affiliated/Future Projects: None \\
\hline $\begin{array}{l}\text { Description: To conduct research and } \\
\text { development on ultra-high performance heat } \\
\text { pumps and thermal storage systems capable of } \\
\text { converting electric power into thermal energy at } \\
\text { night, for high-density storage, and releasing the } \\
\text { energy during the day for air conditioning and } \\
\text { industrial purposes. }\end{array}$ & $\begin{array}{l}\text { Technology: Development of the following: } \\
\text { effective working fluids, new materials for use } \\
\text { as system components; high efficiency } \\
\text { compressor-driven heat pump with energy- } \\
\text { conserving compressor; high-temperature output } \\
\text { heat pump with a common axial multistage } \\
\text { compressor; chemical heat storage with higher } \\
\text { heat storage density. }\end{array}$ \\
\hline $\begin{array}{l}\text { Results: Bench scale plants have been } \\
\text { constructed and operating since 1987; pilot } \\
\text { system to be developed by FY } 1991 \text {. }\end{array}$ & Reference: The Moonlight Project \\
\hline
\end{tabular}




\begin{tabular}{|c|c|}
\hline $\begin{array}{l}\text { Title: Waste Tires Processing Technique Coke } \\
\text { Oven }\end{array}$ & Project Type: Study/demonstration \\
\hline $\begin{array}{l}\text { Organization: Hirohata Ironworks, Nippon } \\
\text { Steel Corporation }\end{array}$ & Date: 1988 \\
\hline End-use Sector: Industry & Affiliated/Future Projects: \\
\hline $\begin{array}{l}\text { Description: Waste tires are used as an } \\
\text { additive to the burning process to supply coke } \\
\text { oven gas. The factory processes } 600 \text { tons of } \\
\text { waste tires a month. Environmental effects have } \\
\text { been small. }\end{array}$ & $\begin{array}{l}\text { Technology: Conservation; municipal solid } \\
\text { waste disposal }\end{array}$ \\
\hline Results: The factory saved on coal costs. & $\begin{array}{l}\text { Reference: } 1989 \text { Successful Cases of Energ. } \\
\text { Conservation }\end{array}$ \\
\hline
\end{tabular}

\begin{tabular}{|c|c|}
\hline $\begin{array}{l}\text { Title: Reduction in Power Consumption by } \\
\text { Forced-Air Blower in Coke Oven }\end{array}$ & Project Type: Study/demonstration \\
\hline Organization: Nissan Steel Company & Date: 1988 \\
\hline End-use Sector: Industry & Affiliated/Future Projects: \\
\hline $\begin{array}{l}\text { Description: Electricity-consuming equipment } \\
\text { at the works uses } 40 \% \text { of the total energy. High } \\
\text { voltage motors drive a forced-air blower that } \\
\text { supplies air for burning fuel gas. }\end{array}$ & Technology: Conservation \\
\hline $\begin{array}{l}\text { Results: A new air supply system was } \\
\text { installed. The works saved } 6 \text { million } \mathrm{kWh} / \mathrm{yr} \\
\text { and } 48 \text { million yen/yr. }\end{array}$ & $\begin{array}{l}\text { Reference: } 1989 \text { Successful Cases of Energy } \\
\text { Conservation }\end{array}$ \\
\hline
\end{tabular}




\begin{tabular}{|c|c|}
\hline Title: Pulp and Paper & Project Type: R\&D \\
\hline $\begin{array}{l}\text { Organization: IEA (Participants are Canada, } \\
\text { Japan, New Zealand, United States, and eight } \\
\text { others) }\end{array}$ & Date: 1981 ; continuing \\
\hline End-use Sector: Industry (pulp and paper) & Affiliated/Future Projects: None \\
\hline $\begin{array}{l}\text { Description: Research and development and } \\
\text { assessments were undertaken that will help } \\
\text { reduce the energy used by the pulp and paper } \\
\text { industry. }\end{array}$ & Technology: Sensors, heat pumps \\
\hline $\begin{array}{l}\text { Results: Recommendations led to an annual } \\
\text { savings equivalent of about } 8,000 \text { barrels of oil } \\
\text { for one pulping machine. A new type of sensor } \\
\text { for monitoring water removal was developed } \\
\text { and tested and is ready for commercial } \\
\text { application. Developed a data base of case } \\
\text { studies of heat pump applications. Researched } \\
\text { powdered wood combustion; a company has } \\
\text { marketed a new burner for powdered wood. }\end{array}$ & $\begin{array}{l}\text { Reference: IEA Joint R\&D Projects, April } \\
\text { 1990, p.32 }\end{array}$ \\
\hline
\end{tabular}

\begin{tabular}{|c|c|}
\hline Title: Fuel Cell Power Generation Technology & Project Type: R\&D \\
\hline $\begin{array}{l}\text { Organization: Japan's Ministry of International } \\
\text { Trade and Industry's Agency of Industrial } \\
\text { Science and Technology }\end{array}$ & Date: 1983 to $1990 \mathrm{~s}$ \\
\hline $\begin{array}{l}\text { End-use Sector: Industry; transportation; } \\
\text { residential building }\end{array}$ & Affiliated/Future Projects: None \\
\hline $\begin{array}{l}\text { Description: This was research to develop } \\
\text { more efficient, energy-conserving power } \\
\text { generation technology. }\end{array}$ & $\begin{array}{l}\text { Technology: Molten carbonate fuel cell; solid } \\
\text { oxide fuel cell; alkaline fuel cell }\end{array}$ \\
\hline $\begin{array}{l}\text { Results: Molten carbonate } 10-\mathrm{kW} \text { cell stacks } \\
\text { and a } 1000-\mathrm{kW} \text { power-generating system were } \\
\text { developed during FY 1986-1987. Alkaline fuel } \\
1 \mathrm{~kW} \text { cell stack was made and tested in FY } \\
1984 \text {. Studies were begun on solid oxide fuel } \\
\text { cell in FY } 1989 .\end{array}$ & Reference: The Moonlight Project \\
\hline
\end{tabular}




\begin{tabular}{|l|l|}
\hline Title: Verification of Geothermal Resources & Project Type: Study/demo; R\&D \\
Exploration and Other Technologies & \\
\hdashline $\begin{array}{l}\text { Organization: New Energy and Industrial } \\
\text { Technology Development Organization (NEDO) }\end{array}$ & Date: 1987 to 1988 \\
\hdashline End-use Sector: Utility (resource planning) & Affiliated/Future Projects: None \\
\hdashline $\begin{array}{l}\text { Description: This was a study to verify } \\
\text { potential geothermal resources. }\end{array}$ & Technology: Computer-based analytical \\
\hdashline $\begin{array}{l}\text { Results: Deep geothermal reservoir was found } \\
\text { in 1987, a result of surface surveys. Develop- } \\
\text { ment of exploration techniques began in } 1988 .\end{array}$ & \\
\hline
\end{tabular}

\begin{tabular}{|c|c|}
\hline $\begin{array}{l}\text { Title: Waste Tires Processing Techniques in } \\
\text { Coke Oven }\end{array}$ & Project Type: Study/demo; R\&D \\
\hline $\begin{array}{l}\text { Organization: Nippon Steel Corporation } \\
\text { (Hirohata Ironworks) }\end{array}$ & Date: 1987 to 1988 \\
\hline End-use Sector: Industry (coke manufacturing) & Affiliated/Future Projects: None \\
\hline $\begin{array}{l}\text { Description: This was a study and a } \\
\text { demonstration to find ways to increase yields of } \\
\text { coke oven gas (COG) by using waste tires to } \\
\text { alleviate the problem of waste tire disposal. } \\
\text { Results to be applied to other coke ovens. }\end{array}$ & $\begin{array}{l}\text { Technology: Waste tires were used in place of } \\
\text { a coal charge as a COG-generating additive in } \\
\text { coke oven; tires were carbonized with coal and } \\
\text { wires were removed by separator and recovered } \\
\text { as scrap metal. Desulfurization system was used } \\
\text { in coke oven to remove harmful sulfuric } \\
\text { compounds from COG. }\end{array}$ \\
\hline $\begin{array}{l}\text { Results: The production of COG was without } \\
\text { any negative effects on coke strength or a less } \\
\text { negative effect on environment. }\end{array}$ & $\begin{array}{l}\text { Reference: } 1989 \text { Successful Cases of Energy } \\
\text { Conservation }\end{array}$ \\
\hline
\end{tabular}




\begin{tabular}{|c|c|}
\hline $\begin{array}{l}\text { Title: Advanced Battery Electric Power Storage } \\
\text { System }\end{array}$ & Project Type: R\&D \\
\hline $\begin{array}{l}\text { Organization: Japan's Ministry of International } \\
\text { Trade and Industry's Agency of Industrial } \\
\text { Science and Technology }\end{array}$ & Date: Unknown \\
\hline End-use Sector: Utility & Affiliated/Future Projects: None \\
\hline $\begin{array}{l}\text { Description: This study was to develop "load- } \\
\text { leveling" technology for storing electric power } \\
\text { at off-peak times, leading to greater plant } \\
\text { efficiency and better energy conservation. }\end{array}$ & $\begin{array}{l}\text { Technology: Four new types of advanced bat- } \\
\text { teries: sodium-sulfur, zinc-chloride, zinc- } \\
\text { bromine, and redox-flow; } 1,000-\mathrm{kW} \text { class pilot } \\
\text { plant developed for each type of battery; } 1,000- \\
\mathrm{kW} \text { class power storage system to study energy } \\
\text { efficiency, reliability, and protective systems. }\end{array}$ \\
\hline Results: The technology is still under study. & Reference: The Moonlight Project \\
\hline
\end{tabular}

\begin{tabular}{|c|c|}
\hline $\begin{array}{l}\text { Title: Challenge of Low-Cost Steam } \\
\text { Generation }\end{array}$ & Project Type: Study/demonstration \\
\hline $\begin{array}{l}\text { Organization: Tohoku Seishi Co., LTD (Akita } \\
\text { Factory) }\end{array}$ & Date: 1984 to 1987 \\
\hline End-use Sector: Utility & Affiliated/Future Projects: None \\
\hline $\begin{array}{l}\text { Description: Study and analysis to find a way } \\
\text { to generate low-cost steam, to be applied to the } \\
\text { recovery boiler. }\end{array}$ & $\begin{array}{l}\text { Technology: Power reduction of auxiliary } \\
\text { equipment, using black liquor concentration } \\
\text { measures to increase steam generation. }\end{array}$ \\
\hline $\begin{array}{l}\text { Results: The amount of power required for } \\
\text { generating unit steam was reduced. }\end{array}$ & $\begin{array}{l}\text { Reference: } 1989 \text { Successful Cases of Energy } \\
\text { Conservation }\end{array}$ \\
\hline
\end{tabular}

\begin{tabular}{|c|c|}
\hline $\begin{array}{l}\text { Title: Energy-saving Measures in Town Gas } \\
\text { Works }\end{array}$ & Project Type: Study/demonstration \\
\hline Organization: Osaka Gas Company & Date: 1988 \\
\hline End-use Sector: Utility & Affiliated/Future Projects: \\
\hline $\begin{array}{l}\text { Description: The Osaka Gas Works vaporizes } \\
\text { liquid natural gas into natural gas, which burns } \\
\text { more efficiently. }\end{array}$ & Technology: Conservation \\
\hline $\begin{array}{l}\text { Results: Power consumption was reduced } 700 \\
\times 10^{4} \mathrm{kWh} \text { annually. }\end{array}$ & $\begin{array}{l}\text { Reference: } 1989 \text { Successful Cases of Energy } \\
\text { Conservation }\end{array}$ \\
\hline
\end{tabular}




\begin{tabular}{|c|c|}
\hline $\begin{array}{l}\text { Title: Saving of Power for Heating Fuel Oil } \\
\text { Unloading Pipings }\end{array}$ & Project Type: Study/demonstration \\
\hline $\begin{array}{l}\text { Organization: Hokuriku Electric Power Co., } \\
\text { Inc. (Fukui Thermal Power Station) }\end{array}$ & Date: $10 / 87$ to $3 / 88$ \\
\hline End-use Sector: Utility (thermal power station) & Affiliated/Future Projects: None \\
\hline $\begin{array}{l}\text { Description: This was a study and a } \\
\text { demonstration to reduce the electricity used to } \\
\text { heat pipes carrying fuel oil offloaded at thermal } \\
\text { power station. }\end{array}$ & $\begin{array}{l}\text { Technology: Change in operations: turning off } \\
\text { the heater of infrequently used piping until } \\
\text { actually needed, and adjusting temperature } \\
\text { setting of frequently used piping to be } 5^{\circ} \mathrm{C} \\
\text { above pour point of the fuel oil being offloaded. }\end{array}$ \\
\hline $\begin{array}{l}\text { Results: Electrical consumption was reduced } \\
\text { by } 61 \% \text {, from } 1.64 \mathrm{MWh} / \mathrm{yr} \text { to } 1.06 \mathrm{MWh} / \mathrm{yr} \text {. }\end{array}$ & $\begin{array}{l}\text { Reference: } 1989 \text { Successful Cases of Energy } \\
\text { Conservation }\end{array}$ \\
\hline
\end{tabular}

\begin{tabular}{|c|c|}
\hline $\begin{array}{l}\text { Title: Superconducting Technology for Electric } \\
\text { Power Apparatuses }\end{array}$ & Project Type: R\&D \\
\hline $\begin{array}{l}\text { Organization: Japan's Ministry of International } \\
\text { Trade and Industry's Agency of Industrial } \\
\text { Science and Technology }\end{array}$ & Date: FY 1988 to FY 1995 \\
\hline End-use Sector: Utility & $\begin{array}{l}\text { Affiliated/Future Projects: Development of } \\
\text { the following: superconducting wires improving } \\
\text { performance of alloy and compound conductors; } \\
\text { superconducting generators; and a refrigeration } \\
\text { system. }\end{array}$ \\
\hline $\begin{array}{l}\text { Description: This was a study of } \\
\text { superconducting power apparatuses to produce } \\
\text { an electric power generator. }\end{array}$ & Technology: Superconducting materials \\
\hline Results: Still under study. & Reference: The Moonlight Project \\
\hline
\end{tabular}




\begin{tabular}{|l|l|}
\hline Title: Hot Dry Rock Power Generation System & Project Type: R\&D \\
\hdashline $\begin{array}{l}\text { Organization: New Energy and Industrial } \\
\text { Technology Development Organization }\end{array}$ & Date: FY 1980 to FY 1989 \\
\hdashline End-use Sector: Utility (power generation) & Affiliated/Future Projects: None \\
\hdashline $\begin{array}{l}\text { Description: This was a study to develop a hot } \\
\text { dry rock power generation system. }\end{array}$ & $\begin{array}{l}\text { Technology: Hydrofracturing with } 1,000 \text { tons } \\
\text { of water }\end{array}$ \\
\hdashline $\begin{array}{l}\text { Results: Hydrofracturing with } 1,000 \text { tons of } \\
\text { water was carried out at a depth of } 1,800 \mathrm{ft} \text { in }\end{array}$ & Reference: The Sunshine Project \\
1986, two production wells were drilled in 1987 & \\
and 1989. A thermal output of $5000 \mathrm{~kW}$ was \\
obtained in a heat extraction test by water circu- \\
lation in 1989.
\end{tabular}

\begin{tabular}{|c|c|}
\hline $\begin{array}{l}\text { Title: Energy Conservation by Operation } \\
\text { Improvement of Soot Blowers of Boiler at Coal- } \\
\text { fired Thermal Power Plant }\end{array}$ & Project Type: Study/demonstration \\
\hline $\begin{array}{l}\text { Organization: Hokkaido Electric Power Co. } \\
\text { (Ebetsu Thermal Power Plant) }\end{array}$ & Date: 1987 to 1988 \\
\hline End-use Sector: Utility & Affiliated/Future Projects: \\
\hline $\begin{array}{l}\text { Description: This was a study and an analysis } \\
\text { to raise the heat-absorption efficiency of a plant } \\
\text { by improving soot blower operations; results are } \\
\text { to be applied to other power plants. }\end{array}$ & $\begin{array}{l}\text { Technology: Operate soot blowers } \\
\text { independently; change blower sequence and } \\
\text { blow soot in two operations }\end{array}$ \\
\hline $\begin{array}{l}\text { Results: Made } 80 \% \text { energy conservation target } \\
\text { accomplishment rate; gross thermal efficiency } \\
\text { rate rose } 1.2 \%\end{array}$ & $\begin{array}{l}\text { Reference: } 1989 \text { Successful Cases of Energy } \\
\text { Conservation }\end{array}$ \\
\hline
\end{tabular}




\begin{tabular}{|c|c|}
\hline $\begin{array}{l}\text { Title: Alcohol and Alcohol Blends as Motor } \\
\text { Fuels }\end{array}$ & Project Type: $R \& D$ \\
\hline $\begin{array}{l}\text { Organization: IEA (participants are Canada, } \\
\text { Japan, New Zealand, United States, and two } \\
\text { others) }\end{array}$ & Date: 1984 ; continuing \\
\hline End-use Sector: Transportation & Affiliated/Future Projects: None \\
\hline $\begin{array}{l}\text { Description: Participants are sharing } \\
\text { information and carrying out tests on the use of } \\
\text { alcohols and blends as motor fuels. This project } \\
\text { includes assessment of costs, distribution } \\
\text { problems, etc. }\end{array}$ & $\begin{array}{l}\text { Technology: Methanol, ethanol blends with } \\
\text { gasoline. }\end{array}$ \\
\hline $\begin{array}{l}\text { Results: Determined acceptable limits for } \\
\text { blending alcohol and evaluated the relative } \\
\text { economics of these blends. This project } \\
\text { includes field tests of methanol use in diesel } \\
\text { engines for heavy goods vehicles. }\end{array}$ & $\begin{array}{l}\text { Reference: IEA Joint R\&D Projects, April } \\
\text { 1990, p. } 23\end{array}$ \\
\hline
\end{tabular}

\begin{tabular}{|c|c|}
\hline Title: Electric Power Storage Technology & Project Type: R\&D \\
\hline Organization: NEDO Moonlight Project & $\begin{array}{l}\text { Date: First phase of project } 1981 \text { to } 1991 \text {; } \\
\text { second phase } 1992 \text { to } 2000 \text {. }\end{array}$ \\
\hline $\begin{array}{l}\text { End-use Sector: Residential building; } \\
\text { transportation }\end{array}$ & $\begin{array}{l}\text { Affiliated/Future Projects: The construction } \\
\text { of a } 1,000-\mathrm{kW} \text { pilot plant was started in } 1988 \text {. }\end{array}$ \\
\hline $\begin{array}{l}\text { Description: There is research on zinc- } \\
\text { bromide, sodium-sulfur, zinc-chloride, redox- } \\
\text { flow batteries, and other high-performance } \\
\text { battery devices. This } 12 \text {-year research project is } \\
\text { divided into long life (load leveling in homes) } \\
\text { and high energy (for use in autos) batteries. }\end{array}$ & $\begin{array}{l}\text { Technology: Advanced batteries, systems } \\
\text { technology, and load leveling technology }\end{array}$ \\
\hline $\begin{array}{l}\text { Results: Each type of battery was developed } \\
\text { and tested in } 1 \mathrm{~kW} \text { and } 10 \mathrm{~kW} \text { sizes between } \\
1980 \text { and } 1991 ; 262 \text { million yen is funded for } \\
1992 .\end{array}$ & Reference: Sunshine Journal \\
\hline
\end{tabular}




\begin{tabular}{|c|c|}
\hline Title: Development of a Solar House & Project Type: R\&D \\
\hline $\begin{array}{l}\text { Organization: New Energy and Industrial } \\
\text { Technology Development Organization (NEDO) }\end{array}$ & Date: FY 1980 to FY 1981 \\
\hline $\begin{array}{l}\text { End-use Sector: Residential building } \\
\text { (renewable energy) }\end{array}$ & Affiliated/Future Projects: None \\
\hline $\begin{array}{l}\text { Description: Study to develop four } \\
\text { demonstration plants for newly built and } \\
\text { existing private housing units, large buildings, } \\
\text { and collective housing units. }\end{array}$ & Technology: Photovoltaics, solar thermal \\
\hline $\begin{array}{l}\text { Results: Operation and evaluation of four } \\
\text { demonstration plants was completed in FY } \\
\text { 1981. }\end{array}$ & Reference: The Sunshine Project \\
\hline
\end{tabular}

\begin{tabular}{|c|c|}
\hline Title: The Chofu Municipal Gymnasium & Project Type: Study/demonstration \\
\hline $\begin{array}{l}\text { Organization: KUME Architects, Engineers, } \\
\text { Tokyo }\end{array}$ & Date: Completed 1985 \\
\hline $\begin{array}{l}\text { End-use Sector: Commercial building } \\
\text { (schools) }\end{array}$ & Affiliated/Future Projects: None \\
\hline $\begin{array}{l}\text { Description: Project to introduce state-of-the- } \\
\text { art technology to an "underground construction." }\end{array}$ & $\begin{array}{l}\text { Technology: An underground public } \\
\text { gymnasium incorporating energy conservation } \\
\text { features such as a construction method that } \\
\text { reduces energy load for heating and cooling by } \\
\text { using the insulation effect and heating ability of } \\
\text { the earth. A gas engine heat pump system, also } \\
\text { designed to recover heat, is the main heat } \\
\text { source. }\end{array}$ \\
\hline Results: Low energy consumption. & Reference: IEA CADDET \\
\hline
\end{tabular}




\begin{tabular}{|c|c|}
\hline $\begin{array}{l}\text { Title: State-of-the-Art Conditioning System for } \\
\text { TWIN } 21 \text { Building in Osaka }\end{array}$ & Project Type: Study/demonstration \\
\hline Organization: Nikken Sekkei Ltd., Japan & Date: 1990 \\
\hline End-use Sector: Commercial building & Affiliated/Future Projects: None \\
\hline $\begin{array}{l}\text { Description: Study of TWIN } 21 \text { project that } \\
\text { aimed to create a more energy-efficient air } \\
\text { conditioning system and to present many new } \\
\text { techniques for effective utilization of energy in } \\
\text { a large building. }\end{array}$ & $\begin{array}{l}\text { Technology: In the air conditioning system, } \\
\text { heat sources comprise a cogeneration system of } \\
\text { gas chiller/heater absorption units and a two- } \\
\text { staged hot water temperature supply system, as } \\
\text { well as an overall use of a variable water } \\
\text { volume system with inverter control. }\end{array}$ \\
\hline $\begin{array}{l}\text { Results: Primary energy savings were } 38 \% \text {; } \\
\text { yearly savings were } 54,500,000 \text { yen; high- } \\
\text { quality internal climate. }\end{array}$ & Reference: IEA CADDET \\
\hline
\end{tabular}

\begin{tabular}{|c|c|}
\hline $\begin{array}{l}\text { Title: Evaluation of Photovoltaic Modules in } \\
\text { Downtown Tokyo }\end{array}$ & Project Type: Study/demonstration \\
\hline $\begin{array}{l}\text { Organization: Science University of Tokyo } \\
\text { (Faculty of Engineering) }\end{array}$ & Date: $12 / 1 / 88$ to $2 / 28 / 89$ \\
\hline End-use Sector: Renewable energy (PV) & Affiliated/Future Projects: None \\
\hline $\begin{array}{l}\text { Description: A study of the relationship } \\
\text { between the output of } 3 \text { PV modules, amor- } \\
\text { phous, single, and polycrystalline, and the } \\
\text { spectral solar radiation at each wavelength in } \\
\text { downtown Tokyo. }\end{array}$ & $\begin{array}{l}\text { Technology: PV module evaluation system: } \\
\text { pyrometer, global spectroradiometer, data } \\
\text { logger, and three types of PV modules }\end{array}$ \\
\hline $\begin{array}{l}\text { Results: There is a recognized difference } \\
\text { between the distribution ratio of spectral solar } \\
\text { radiation for clear days and cloudy days. } \\
\text { Module efficiencies are changed fairly by the } \\
\text { combination with spectral radiation. }\end{array}$ & Reference: Clean and Safe Energy Forever \\
\hline
\end{tabular}




\begin{tabular}{|l|l|}
\hline Title: Photovoltaic Power Generating Systems & Project Type: R\&D \\
\hdashline $\begin{array}{l}\text { Organization: New Energy and Industrial } \\
\text { Technology Development Organization (NEDO) }\end{array}$ & Date: 1986 \\
\hdashline End-use Sector: Renewable energy & Affiliated/Future Projects: None \\
\hdashline Description: Study to develop centralized & Technology: Photovoltaic cells \\
locations for PV power generating systems. & \\
\hdashline Results: Operation trial completed by FY & Reference: The Sunshine Project \\
1986; research on system in progress since FY & \\
1986.
\end{tabular}

\begin{tabular}{|c|c|}
\hline $\begin{array}{l}\text { Title: Research Progress in Crystalline Silicon } \\
\text { Solar Cells in Japan }\end{array}$ & Project Type: R\&D \\
\hline $\begin{array}{l}\text { Organization: Tokyo University of Agriculture } \\
\text { and Technology (Division of Electronic and } \\
\text { Information Engineering) }\end{array}$ & Date: 1986; continuing \\
\hline End-use Sector: Renewable energy (PV) & Affiliated/Future Projects: None \\
\hline $\begin{array}{l}\text { Description: Advancing research of crystalline } \\
\text { silicon solar cells. }\end{array}$ & $\begin{array}{l}\text { Technology: Fabrication of higher quality, cast } \\
\text { polycrystalline ingots and realization of } \\
\text { crystalline silicon solar cells with an efficiency } \\
\text { of } 16 \% \text { using the cast material }\end{array}$ \\
\hline $\begin{array}{l}\text { Results: Cell efficiencies of mono- and poly- } \\
\text { crystalline silicon cells were improved close to } \\
20 \% \text {, and a new four-year government project } \\
\text { was introduced for higher-efficiency, crystalline } \\
\text { solar cells having a thin substrate and tandem } \\
\text { structures. }\end{array}$ & Reference: Clean and Safe Energy Forever \\
\hline
\end{tabular}

\begin{tabular}{|c|c|}
\hline Title: Industrial Solar System & Project Type: R\&D \\
\hline $\begin{array}{l}\text { Organization: New Energy and Industrial } \\
\text { Technology Development Organization (NEDO) }\end{array}$ & Date: FY 1984 to FY 1987 \\
\hline End-use Sector: Renewable energy & Affiliated/Future Projects: None \\
\hline $\begin{array}{l}\text { Description: Study to develop industrial power } \\
\text { from renewable energy. }\end{array}$ & $\begin{array}{l}\text { Technology: Fixed temperature heat process, } \\
\text { cascaded temperature heat process, advanced } \\
\text { heat process }\end{array}$ \\
\hline $\begin{array}{l}\text { Results: Advanced heat process has been } \\
\text { operating from FY } 1987 \text {. }\end{array}$ & Reference: The Sunshine Project \\
\hline
\end{tabular}




\begin{tabular}{l:l}
\hline Title: Wind Energy Conversion Systems & Project Type: R\&D; study/demo \\
Organization: IEA (Participants include \\
Canada, Japan, New Zealand, United States, and \\
12 others)
\end{tabular}

\begin{tabular}{|l|l|}
\hline Title: Ceramic Gas Turbine. & Project Type: Study/demonstration \\
\hdashline Organization: NEDO Moonlight Project & Date: 1988 to 1996 \\
\hdashline End-use Sector: Renewable energy & $\begin{array}{l}\text { Affiliated/Future Projects: Studies on } \\
\text { environmental implications, performance } \\
\text { evaluation, and component technology }\end{array}$ \\
\hdashline $\begin{array}{l}\text { Description: For } 1992, \text { a } 300-\mathrm{kW} \text { turbine will } \\
\text { be developed operating at } 1,200^{\circ} \mathrm{C} .\end{array}$ & $\begin{array}{l}\text { Technology: Ceramic materials, component } \\
\text { technology, and gas turbine engine systems }\end{array}$ \\
\hdashline $\begin{array}{l}\text { Results: The target is an } 80 \% \text { efficient turbine } \\
\text { operating at } 1,350^{\circ} \mathrm{C} \text { using cogeneration. }\end{array}$ & \begin{tabular}{l} 
Reference: Sunshine Journal \\
\hline
\end{tabular}
\end{tabular}




\begin{tabular}{|c|c|}
\hline Title: Solar Heat Power Plant & Project Type: $R \& D$ \\
\hline $\begin{array}{l}\text { Organization: New Energy and Industrial } \\
\text { Technology Development Organization (NEDO) }\end{array}$ & Date: FY 1983 \\
\hline $\begin{array}{l}\text { End-use Sector: Renewable energy (solar } \\
\text { thermal power plants) }\end{array}$ & Affiliated/Future Projects: None \\
\hline $\begin{array}{l}\text { Description: Study to develop solar heat power } \\
\text { plant }\end{array}$ & $\begin{array}{l}\text { Technology: Two } 1,000-\mathrm{kW} \text { solar heat power } \\
\text { systems (curved surface solar energy collection } \\
\text { system and the tower-type solar energy } \\
\text { collection system) }\end{array}$ \\
\hline $\begin{array}{l}\text { Results: Operational trials completed in FY } \\
\text { 1983. }\end{array}$ & Reference: The Sunshine Project \\
\hline
\end{tabular}

\begin{tabular}{|c|c|}
\hline Title: Bioenergy & Project Type: R\&D (engineering studies) \\
\hline $\begin{array}{l}\text { Organization: IEA (participants are Canada, } \\
\text { Japan, New Zealand, United States, and } 10 \\
\text { others) }\end{array}$ & Date: 1978 ; continuing \\
\hline End-use Sector: Renewable energy (biomass) & Affiliated/Future Projects: None \\
\hline $\begin{array}{l}\text { Description: Several tasks to enhance the } \\
\text { growth and harvesting of cost-effective biomass } \\
\text { and bioenergetic feedstocks, including forest } \\
\text { biomass, agricultural, and municipal wastes. }\end{array}$ & $\begin{array}{l}\text { Technology: Short rotation crops, conversion } \\
\text { of woody feedstocks to high-value fuels, use of } \\
\text { municipal solid wastes for energy }\end{array}$ \\
\hline $\begin{array}{l}\text { Results: Tasks include improving biomass } \\
\text { growth and production technology in short } \\
\text { rotation forestry; developing improved methods } \\
\text { for harvesting, processing, and transporting } \\
\text { forest biomass; converting woody feedstocks to } \\
\text { high-value fuels; and improving technologies for } \\
\text { conversion of municipal solid wastes and straw } \\
\text { to energy. }\end{array}$ & $\begin{array}{l}\text { Reference: IEA Joint R\&D Projects, April } \\
\text { 1990, p. } 53\end{array}$ \\
\hline
\end{tabular}




\begin{tabular}{|l|l|}
\hline Title: International Cooperation & Project Type: R\&D \\
\hdashline Organization: NEDO Moonlight Project & Date: Ongoing \\
\hdashline End-use Sector: All sectors & Affiliated/Future Projects: \\
\hdashline $\begin{array}{l}\text { Description: Japan participates in IEA joint } \\
\text { projects, Japan-Australia photovoltaic research, }\end{array}$ & Technology: Conservation \\
Japan-Thailand fuel cell research. & \\
\hdashline $\begin{array}{l}\text { Results: Japan has completed international } \\
\text { research projects with the U.S., France, and } \\
\text { other countries. Japan provided 171 million yen } \\
\text { in funding for international cooperation in 1990. }\end{array}$ & \\
\hline
\end{tabular}

Japan

86 


\section{Korea}

Korea occupies a peninsula on the east coast of Asia and has a population of 42.4 million and a total land area of $99,143 \mathrm{~km}^{2}$. Approximately three-fourths of all Koreans live in urban areas.

Korean gross domestic product (GDP) reached US $\$ 236,400$ million in 1990 , up from US $\$ 3,000$ million in 1965 . This is an average annual growth rate of $9.7 \%$ for 1980 to 1990 . The GDP came from the following market sectors: agriculture (9\%), industry (45\%), and services (46\%); within industry, manufacturing comprised $31 \%$ of the GDP. The GDP rose $9 \%$ in 1990 . A GDP growth of $8.5 \%$ was predicted for 1991.

For 1990 , the average lending rate was $10 \%$. The average rate of inflation was $5.1 \%$ from 1980 to 1990.

In 1990, exports totaled US $\$ 64,837$ million and imports totaled US $\$ 69,585$ million. Over the period 1980 to 1990 , this represents an average annual growth rate for exports of $12.8 \%$ and an average annual growth rate for imports of $10.8 \%$. Despite the recent success in world markets, South Korea sustained a constant trade deficit over the period 1965 to 1985.

South Korea and three other newly industrialized countries in Asia-Hong Kong, Singapore, and Chinese Taipei-make up the so-called "Little Tigers." These countries grew rapidly due to export-led economic strategy. For Korea, this meant a shift away from traditional agriculture and towards largescale manufacturing.

The Heavy and Chemical Industries Promotion Plan fostered growth in heavy engineering and chemical processing. This includes nonferrous metals, shipbuilding, industrial machinery, electronics, and petrochemicals. By 1990, Korea was the sixth largest producer of steel. Other important products include textiles, footwear, and automobiles.

For 1992, the Pacific Economic Outlook predicts that domestic inflation in Korea will rise $10 \%$. Construction will moderate, but export growth will continue. GNP growth for 1992 will be approximately $8 \%$.

\section{Energy Use and Policy Issues}

Korea's total energy demand equaled 82 million tons of oil equivalent (Mtoe) in 1989. According to forecasts by the Korea Energy Economics Institute in 1990, the total energy demand will grow at an average rate of $3 \%$ between 1988 and 2030 . The total energy demand should reach 257 Mtoe at the end of this period.

Per capita energy consumption equaled 1,898 kilograms of oil equivalent (kgoe) in 1990, up from 238 kgoe in 1965. For the period of 1980 to 1990, energy consumption grew at an annual rate of $8.1 \%$. For the years between 1965 and 1980, energy consumption grew at an annual rate of $12.1 \%$.

In 1989, demand for total energy came from the following market sectors: industry $(47 \%)$, transportation (19\%), and residential and commercial (30\%). 
Korea depends on domestic (12\%) and imported (88\%) sources of energy. There is a modest hydropower potential (3,200 MW) and significant amounts of coal. The sources of energy in 1989 were coal $(30 \%)$, oil $(50 \%)$, nuclear $(14.5 \%)$, and fuelwood $(1 \%)$. The government has implemented a policy to reduce the reliance on foreign oil. This program has developed indigenous resources, developed nuclear power, and introduced liquefied natural gas.

The Korea Electric Power Company (KEPCO) is the only electric utility in the Republic of Korea. Its peak load reached $13,658 \mathrm{MW}$ in 1989. The installed capacity was 20,044 MW and consisted of fossil fuel $(33 \%)$, nuclear $(12 \%)$ and hydro (6\%). Experts expect demand to grow further as the economy expands.

Korea is currently attempting to develop indigenous oil and gas resources. While no oil has been found yet, gas discoveries are promising. In addition, Korean companies are developing petroleum, gas, and coal reserves overseas.

Firewood consumption, which accounted for more than $50 \%$ of Korea's primary energy demand in the sixties, now accounts for only $1.3 \%$ of total energy demand.

Korea has steadily increased its use of nuclear power since its introduction in 1977. By 1989, nuclear accounted for $14.5 \%$ of the country's primary energy supply and more than $50 \%$ of electricity generation.

\section{Energy Efficiency and Conservation}

Korea, through the Korea Institute of Energy and Resources, pursues energy efficiency and conservation to reduce growth in demand. The institute sponsored research ranging from basic research on energy demand to architectural design. Some of the studies have examined heating methods (Auh P. et al. 1989), floor plans (Kang L. et al. 1990), and passive solar technologies (Chun W. et al. 1990). University researchers have also looked at conservation. These studies include investigations on fuel demand in electricity generation (Chung-Sok Suh 1990) and economic analysis of household energy consumption (Sang-Gon Lee 1989).

Korea pursues four types of programs: Energy Management Audit and Technical Guidance, Financial Assistance, Publicity and Information Service, Education and Training, and Integrated Energy Schemes.

Energy audits are conducted by experts for factories (ceramics, metals, chemicals, foods, paper, and textiles), large buildings, and transport companies to identify inefficient use and losses of energy. Technical guidance is provided to the plants to reduce energy losses and improve efficiencies. The payback period for such audits averages from less than one year (for shipping companies) to 1.9 years for the industrial sector. Approximately 75,000 audits have been conducted.

Financial assistance includes loans at a favorable rate for conservation investments and research and development (R\&D) activities. These special loans are provided for such projects as replacement of inefficient industrial energy equipment, construction of central-heating plant and district-heating systems, and insulation of residential buildings. Since 1980 , US $\$ 2,730$ million has been made available for replacement of inefficient facilities. The payback on these projects is expected to average 
3.8 years. Grants are also available for $R \& D$ of technologies that are expected to become commercial in the near future. Energy-saving equipment also receives favorable tax treatment.

Publicity and information campaigns for energy conservation have been conducted through mass media, posters, and pamphlets. Various periodicals are published and distributed. In addition, there are 14 consultation centers located in each province and big city to offer free advice to engineers and the public.

Education and training courses are offered for energy managers of energy-intensive firms and boiler/furnace operators. Technicians and professionals working in the energy field are offered seminars as well.

Integrated energy schemes are either district-heating or central-heating plants in industrial complexes. District heating was introduced in 1987 in areas of dense population and has contributed to environmental and energy goals. Savings are estimated to be US $\$ 10$ million per year. The government strongly supports the expansion of district heating and plans to heat some 1.55 million households (15\% of the households) in 43 areas by 2001. Central-heating plants are now operating in four complexes, and they supply both heat and electricity in 4,718 gigajoules per hour (1,127 gigacalories per hour) of heat and 188 megawatts (MW) of capacity for 372 companies. Savings are estimated to be US\$46 million.

Actual energy conservation projects include R\&D and demonstrations. Since 1987 , US $\$ 450,000$ was provided by grants for 18 subjects that have a common interest to many users and are expected to become commercial within one year. A new, expanded Five Year R\&D Plan for Energy Efficiency has been designed for 1991 to 1996 , with one-half the budget of US $\$ 54.8$ million to be available as subsidies and one-half as loans on favorable terms. Demonstration projects are for new and innovative energy technologies and equipment. Technical support and loans at a favorable rate are available for such projects.

Electric power demand has risen as the economy has developed. Now, however, demand-side investments also are being made. In addition, electricity tariff structures have been introduced with on-peak and off-peak rates. Off-peak rates are approximately $40 \%$ the regular period charge. Seasonal rates also are being introduced.

The government also works toward energy conservation and efficiency through regulations and administrative guidance efforts. For example, consumers who use more than 250 tons of oil of fuel/heat or 1 million kilowatt-hours of electricity must submit a report to the Minister of Energy and Resources on their energy-consuming plan and results. In addition, they must employ a licensed energy engineer. At present, there are 3,000 plants or buildings that meet this requirement.

The government provides energy management guidelines for about 80 items, such as combustionefficiency improvement, heat loss prevention, etc. In case of a failure to meet the guidelines, an energy audit may be undertaken. Other regulations are in effect for new construction and expansion of facilities, motor vehicles, etc. 
On a sector-by-sector basis, the needs, capabilities needed to improve efficiency, and barriers can be summarized as follows:

- Industrial sector

- Needs-restructuring toward less energy-intensive activities; special supervision of energy-intensive industries; and improved energy intensity

- Capabilities - conducting energy audits of higher-use firms; providing technical assistance following energy audits; strengthening financial incentives; establishing efficiency targets for end-use products

- Barriers-lower energy prices for industrial use; low willingness to invest in efficiency; and shortage of funds for conservation investments.

- Residential and Commercial Sector

- Needs-stronger building standards; special supervision of energy-intensive buildings; standards for energy-using appliances

- Capabilities-implementation of various regulations and standards; implementation of efficiency standards and labels for major energy-using products; and providing rebates for purchase of high-efficiency products

- Barriers-low energy price; lack of willingness for efficient use among people; and lack of motivation of energy suppliers to participate in conservation programs.

- Transportation

- Needs-improved transport and traffic systems; improved fuel efficiency of vehicles; expansion of mass transport

- Capabilities-restructuring of vehicle tax system; preparing high occupancy vehicle lanes; constructing integrated freight terminals; establishing target fuel efficiency for vehicles

- Barriers-increasing number of vehicles associated with increasing living standard; shortage of budget funds for new roads; lack of mass transport.

Currently, the Korean government encourages ambitious R\&D efforts focused on alternative energy sources. The government's goal is to have alternative energy contribute $3 \%$ to the primary energy demand by 2000 . Results of this policy have been positive. For example, the number of active solar energy systems in use increased from 1,500 in 1986 to 8,660 in 1989. The government hopes this will reach 500,000 by 2001 . The number of passive solar systems also grew from 2,000 in 1986 to 2,307 in 1989 and should number one million in 2001.

\section{Bibliography}

Application and Field Experience with Photovoltaic Systems for Rural Electrification Report 4.1.8; Song, J. [Korea Institute of Energy and Resources (Republic of Korea)] 
Energy Efficiency and Conservation Programs in ROK; Ministry of Energy and Resources, Republic of Korea; 1991

Energy for Tomorrow. Division 4: Energy and Technology Session 4.1: Energy Research and Development and Other Major Energy Technology Issues, Canadian National Committee; 1989

KEPCO's National Control Center with an Advanced Energy Management System; Kim, Y.H. [Korea Electric Co., Seoul (Republic of Korea)], Fukushima, N. (Toshiba Corp., Hibiya Office, Tokyo 100 (JP)), Dy Liacco; November 1991

Major Economic Influences on Energy, Session 3.2, 14th Congress of the World Energy Conference; September 1989

Proceedings of the 15th National Passive Solar Conference, Volume 15; S.M. Burley, M.J. Coleman, American Solar Energy Society Inc.; 1990

Revised Survey of Energy Efficiency and Conservation; Ministry of Energy and Resources, Republic of Korea; 1991

South Korea Asia-Pacific Energy Series Country Report; Babak Kiani, Julia Culver Hopper; April 1991 


\begin{tabular}{|c|c|}
\hline Title: Paper Sludge Dryer & Project Type: R\&D; study/demo \\
\hline $\begin{array}{l}\text { Organization: Korea Energy Management } \\
\text { Corporation }\end{array}$ & Date: 1988 \\
\hline End-use Sector: Industry & Affiliated/Future Projects: \\
\hline $\begin{array}{l}\text { Description: A fluidized bed dryer for paper } \\
\text { mill sludge was demonstrated. }\end{array}$ & Technology: Biomass, fluidized bed dryer \\
\hline Results: & Reference: APEC Response \\
\hline Title: Electric Induction Heater & Project Type: R\&D; study/demo \\
\hline $\begin{array}{l}\text { Organization: Korea Energy Management } \\
\text { Corporation, Korea Institute of Machinery and } \\
\text { Metals (KIMM) }\end{array}$ & Date: 1987 \\
\hline End-use Sector: Industry & Affiliated/Future Projects: \\
\hline $\begin{array}{l}\text { Description: The project developed an electric } \\
\text { induction heater for bolt manufacturing. }\end{array}$ & Technology: Heat treatment \\
\hline Results: Energy savings were achieved. & Reference: APEC Response \\
\hline
\end{tabular}

Title: Ceramic Heat Exchanger

Organization: Korea Energy Management Corporation, Daemyungno Industry, Korea Institute of Energy and Resources (KIER)

End-use Sector: Industry

Description: The project designed and analyzed the performance of a ceramic heat exchanger.

Results:
Project Type: R\&D; study/demo

Date: 1990

Affiliated/Future Projects:

Technology: Waste heat recovery of furnaces and kilns

Reference: APEC Response 
Title: Thermal Effects of Two Different Heating Methods for Apartment Buildings

Organization: Korea Institute of Energy and Resources

End-use Sector: Residential building

Description: This study determined the optimal system for space heating of apartment buildings in Korea. They studied intermittent and continuous heating methods for large apartment buildings.

Results: Continuous heating requires $15 \%$ less energy than intermittent heating.
Project Type: R\&D; study/demo

Date: 1989

Affiliated/Future Projects:

Technology: Thermal conservation

Reference: Clean and Safe Energy Forever

Project Type: R\&D

Date: 1989 to 1990

Affiliated/Future Projects:

Technology:

Reference: APEC Response

Results: The project developed heat recovery system using PE film and wood chips and developed a continuous manufacturing process for the heat recovery system.

Title: Energy Conservation Research and Development Project

Organization: Ministry of Energy and Resources

End-use Sector: Commercial building

Description: Since 1987, US $\$ 450,000$ funded projects in 18 subjects that have a good chance for commercialization. $\mathrm{R} \& \mathrm{D}$ is performed as joint efforts between companies and national research institutes. There is an expected savings of US\$19.6 million.

Results:
Project Type: Policy assessment

Date: 1986; continuing

Affiliated/Future Projects: A new US $\$ 54.8$ million conservation $R \& D$ project will span 1991 - 1996.

Technology: Conservation

Reference: APEC Response, Energy Efficiency and Conservation in ROK 


\begin{tabular}{|c|c|}
\hline Title: Lignin for Energy & Project Type: R\&D \\
\hline $\begin{array}{l}\text { Organization: Korea Energy Management } \\
\text { Corporation, Institute of Seoul National } \\
\text { University }\end{array}$ & Date: 1989 to 1991 \\
\hline End-use Sector: Industry & Affiliated/Future Projects: \\
\hline $\begin{array}{l}\text { Description: Develop a method to use lignin as } \\
\text { an energy source. Lignin is pollution free and } \\
\text { naturally abundant. }\end{array}$ & Technology: Biomass \\
\hline $\begin{array}{l}\text { Results: Various carbohydrates in lignin } \\
\text { decomposition were observed. Lignin- } \\
\text { decomposing bacteria were identified. }\end{array}$ & Reference: APEC Response \\
\hline
\end{tabular}

\begin{tabular}{l:l}
\hline Title: KEPCO's National Control Center & Project Type: Study/demonstration \\
\hdashline Organization: Korea Electric Power \\
Corporation (KEPCO), Toshiba Power Corp.
\end{tabular}




\begin{tabular}{|c|c|}
\hline $\begin{array}{l}\text { Title: Electronic Ballasts for Dimming } \\
\text { Fluorescent Light Bulbs }\end{array}$ & Project Type: R\&D; study/demonstration \\
\hline $\begin{array}{l}\text { Organization: Korea Energy Management } \\
\text { Corporation, Korea Institute of Science and } \\
\text { Technology (KIST) }\end{array}$ & Date: 1991 \\
\hline $\begin{array}{l}\text { End-use Sector: Residential, commercial } \\
\text { buildings }\end{array}$ & Affiliated/Future Projects: \\
\hline $\begin{array}{l}\text { Description: A remote control dimming circuit } \\
\text { and stabilization circuit were developed for } \\
\text { fluorescent lighting. }\end{array}$ & $\begin{array}{l}\text { Technology: Conservation, illumination } \\
\text { controls }\end{array}$ \\
\hline Results: & Reference: APEC Response \\
\hline Title: Energy Management and Audits & Project Type: Audit \\
\hline $\begin{array}{l}\text { Organization: Ministry of Energy and } \\
\text { Resources }\end{array}$ & Date: 1980 ; continuing \\
\hline $\begin{array}{l}\text { End-use Sector: Industry; commercial, } \\
\text { residential buildings }\end{array}$ & $\begin{array}{l}\text { Affiliated/Future Projects: A "Survey of } \\
\text { Industrial Energy Conservation Status and Free } \\
\text { Audit Projects" will ask } 1,250 \text { plant operators } \\
\text { about energy conservation. }\end{array}$ \\
\hline $\begin{array}{l}\text { Description: Energy experts conduct energy } \\
\text { audits for factories, large buildings, and } \\
\text { transport companies to identify inefficiencies } \\
\text { and losses. }\end{array}$ & Technology: Conservation \\
\hline $\begin{array}{l}\text { Results: More than } 75,000 \text { audits have saved } \\
1,228 \text { thousand tones of oil equivalent per year. } \\
\text { These include } 790 \text { audits of industry, } 68,000 \\
\text { technical guidance schemes, } 794 \text { audits of public } \\
\text { buildings, } 68 \text { audits of transport companies, and } \\
24 \text { audits of shipping companies. The payback } \\
\text { periods ranged from } 0.7 \text { to } 3.3 \text { years. }\end{array}$ & $\begin{array}{l}\text { Reference: APEC Response, Energy Efficiency } \\
\text { and Conservation in ROK }\end{array}$ \\
\hline
\end{tabular}




\begin{tabular}{|c|c|}
\hline Title: Financial Assistance for Conservation & Project Type: Study/demonstration \\
\hline $\begin{array}{l}\text { Organization: Ministry of Energy and } \\
\text { Resources, Petroleum Business Fund }\end{array}$ & Date: 1983 ; continuing \\
\hline $\begin{array}{l}\text { End-use Sector: Industry; commercial, } \\
\text { residential buildings }\end{array}$ & $\begin{array}{l}\text { Affiliated/Future Projects: } 254 \text { demonstration } \\
\text { projects received } \$ 215.9 \text { million in loans and } \\
\text { have expected savings of } \$ 50 \text { million a year. }\end{array}$ \\
\hline $\begin{array}{l}\text { Description: Loans at favorable terms, grants, } \\
\text { and } 3 \% \text { to } 10 \% \text { tax credits are available to fund } \\
\text { conservation activities. These include research } \\
\text { and development, replacing old machinery, } \\
\text { insulation of residential buildings, and } \\
\text { demonstration projects. }\end{array}$ & Technology: Conservation \\
\hline $\begin{array}{l}\text { Results: US } \$ 2,370 \text { million has funded } 7,680 \\
\text { projects. US } \$ 1,920 \text { million came from the } \\
\text { petroleum business fund and US } \$ 810 \text { from a } \\
\text { Special Banking and Loan Rationalization Fund. } \\
\text { The payback periods averaged } 3.8 \text { years. }\end{array}$ & $\begin{array}{l}\text { Reference: APEC Response, Energy Efficiency } \\
\text { and Conservation in ROK }\end{array}$ \\
\hline
\end{tabular}

\begin{tabular}{|c|c|}
\hline Title: Conservation Publicity Campaign & Project Type: Policy assessment \\
\hline $\begin{array}{l}\text { Organization: Ministry of Energy and } \\
\text { Resources }\end{array}$ & Date: Ongoing \\
\hline $\begin{array}{l}\text { End-use Sector: Industry; commercial, } \\
\text { residential buildings }\end{array}$ & $\begin{array}{l}\text { Affiliated/Future Projects: Energy } \\
\text { conservation awards; Energy Management, } \\
\text { monthly; New Technology Information, weekly; } \\
\text { Industrial Technology, biweekly; Technology } \\
\text { Information Guidebook, yearly. }\end{array}$ \\
\hline $\begin{array}{l}\text { Description: The government promotes energy } \\
\text { conservation through mass media, posters, and } \\
\text { various periodicals. Energy Management } \\
\text { magazine gives technical information on news } \\
\text { and energy policy changes to } 8,000 \text { subscribers. }\end{array}$ & Technology: \\
\hline $\begin{array}{l}\text { Results: There are } 14 \text { energy conservation } \\
\text { centers throughout the country. Each November } \\
\text { is energy conservation month. An energy } \\
\text { conservation exhibition is held each year. }\end{array}$ & $\begin{array}{l}\text { Reference: APEC Response, Energy Efficiency } \\
\text { and Conservation in ROK }\end{array}$ \\
\hline
\end{tabular}




\begin{tabular}{|l:l|}
\hline Title: Conservation Education and Training & Project Type: Policy assessment \\
\hdashline Organization: Ministry of Energy and \\
Resources
\end{tabular}

\begin{tabular}{|c|c|}
\hline $\begin{array}{l}\text { Title: New and Renewable Energy Research } \\
\text { and Development }\end{array}$ & Project Type: Policy assessment \\
\hline $\begin{array}{l}\text { Organization: Ministry of Energy and } \\
\text { Resources }\end{array}$ & Date: 1987 ; continuing \\
\hline $\begin{array}{l}\text { End-use Sector: Industry; commercial, } \\
\text { residential building }\end{array}$ & $\begin{array}{l}\text { Affiliated/Future Projects: The government } \\
\text { hopes NRSE will supply } 3 \% \text { of energy by } 2001 \text {. }\end{array}$ \\
\hline $\begin{array}{l}\text { Description: The New and Renewable Energy } \\
\text { Research and Development Act of } 1987 \text { funded } \\
\text { over US } \$ 375 \text { million for } 1988 \text { to } 2001 \text {. }\end{array}$ & Technology: Renewable energy \\
\hline $\begin{array}{l}\text { Results: During } 1988 \text { to } 1990,17.1 \text { million } \\
\text { subsidized } 265 \text { projects. US } \$ 79.1 \text { million was } \\
\text { loaned for New and Renewable Sources of } \\
\text { Energy (NRSE) activities. }\end{array}$ & $\begin{array}{l}\text { Reference: APEC Response, Energy Efficiency } \\
\text { and Conservation in ROK }\end{array}$ \\
\hline
\end{tabular}




\section{Malaysia}

Malaysia occupies $332,000 \mathrm{~km}^{2}$ in Southeast Asia and is divided into west and east regions separated by $750 \mathrm{~km}$ of the South China Sea. West Malaysia, or Peninsular Malaysia, forms the southern tip of the Southeast Asian land mass and shares common boundaries with Thailand and Singapore. East Malaysia, consisting of the states of Sarawak and Sabah, occupies the northwest section of Borneo. Malaysia is a member of the Association of Southeast Asian Nations (ASEAN).

Malaysia is one of the least populated countries in the world, inhabited by 17 million people. The prime minister feels that a larger population base is necessary to continue development and has granted tax incentives to larger families to promote population growth.

A parliamentary system of government, divided into 13 state governments, governs Malaysia. The 154 members of the House of Representatives elect a constitutional monarch as the head of government. There is also a senate composed of two members from each state.

Malaysian gross domestic product (GDP) reached US\$42,400 million in 1990, up from US $\$ 3,130$ million in 1965 . For the period between 1980 and 1990 , the economy grew at an annual rate of 5.2\%. The GDP came from the following market sectors: agriculture (12\%), industry (33\%), and services (55\%); within industry, manufacturing comprised $24 \%$ of GDP. The GDP rose $10.0 \%$ in 1990. A GDP growth of $8.3 \%$ was predicted for 1991.

For 1990 , the lending rate averaged $7.2 \%$. The average rate of inflation was $1.6 \%$.

Malaysia ranks among the world's leading producers of rubber, palm oil, tropical hardwood, tin, and paper. Other agricultural products include cocoa, pineapple, natural gas, tobacco, and sugar cane. Malaysia is the third largest producer of semiconductor devises. Televisions, radios, textiles, and petroleum also are important goods in the economy.

In 1990 , exports totaled US $\$ 29,409$ million and imports totaled US $\$ 29,251$ million. Malaysia's chief trading partners are Japan, Singapore, and the United States, but Malaysia has been cultivating trade relations with China, India, Hong Kong, and Chinese Taipei. Between 1980 and 1990, exports grew at an average annual growth rate of $1.4 \%$, and imports shrank at an average annual shrinkage rate of 8.4\%. Manufacturing accounted for $60 \%$ of total export earnings in 1990 .

Malaysia encourages foreign investment and has a variety of incentives, including tax breaks, protective tariffs, and import duty concessions. Over the past decade there has been a special drive for export-oriented electronics. Malaysia is now seeking high technology, capital-intensive investment to balance the economy's reliance on the industrial sector.

For 1992, the Pacific Economic Outlook predicts Malaysia will continue to experience GDP growth close to $8 \%$. The government is expected to sustain public expenditures on roads, highways, and bridges, which will continue growth in the construction sector. Private consumption is forecast to grow $7.7 \%$ in 1992 .

The Pacific Economic Outlook also predicts strong performance for exports because of a diversified manufacturing base. Total manufacturer exports should continue to grow faster than imports. The labor market should remain tight (with unemployment around 6\%) and a "stable political climate should sustain business confidence in the economy." 


\section{Energy Use and Policy Issues}

Malaysia's final energy demand reached 14 million tons of oil equivalent (Mtoe) in 1990. The energy supply came from oil (61\%), gas (3\%), coal (16\%), hydro (3\%), and renewables (17\%). Demand is expected to increase threefold, to about 36 Mtoe by 2005 .

Per capita energy consumption equaled 974 kilograms of oil equivalent (kgoe) in 1990, up from 313 kgoe in 1965 . For the period of 1980 to 1990 , energy consumption grew at an annual rate of $7.8 \%$. For the years between 1965 and 1980, energy consumption grew at an annual rate of $6.7 \%$.

Demand for energy came from the following market sectors: industry (32\%), transportation (42\%), commercial $(5.6 \%)$, residential $(6.2 \%)$, and other $(14.3 \%)$. Malaysia has looked toward fuel substitution to conserve fuel in the transportation sector. Liquefied petroleum gas has been unsuccessful because of high conversion costs, but compressed natural gas is now being tried.

The National Energy Balances estimated reserves of oil to be 3.05 billion barrels. Natural gas reserves total 52.4 trillion cubic feet (1.48 trillion cubic meters). Hydroelectric power potential totals 20,000 MW. Electricity is supplied and distributed by three public utility boards: Tenaga Nasional Berhad, Sabah Electricity Board, and Sarawak Electricity Supply Corporation. Electricity demand reached 1.8 Mtoe in 1990. It is expected to reach 5.5 Mtoe by 2000 .

The electricity grid extends to most places on peninsular Malaysia. While the National Electricity Board (NEB) has promoted the use of natural gas for electricity generation, efforts also have been made to expand hydroelectric capacity. Demand for electricity came from the following market sectors in 1986: residential (16\%), commercial (30\%), industrial (42\%), and other $(12 \%)$.

Growing industrialization and urbanization increased the demand for electricity at an average rate of $10.45 \%$ between 1973 and 1985 . This accounted for $46.3 \%$ of the total energy supply.

The NEB participates in a rural electrification program. Peninsular Malaysia is expected to be fully electrified by 1995, but electrification in Sabah and Sarawak is still low. The Ministry of Education also has supplied funding for rural electrification of schools.

Several institutions address various aspects of energy policy in Malaysia. The focal point for implementation and coordination is the Ministry of Energy, Telecommunications, and Posts (METP), which provides the official communications channel between the three electric utilities and the Cabinet. Development and promotion of petroleum and gas are the responsibility of PETRONAS (the national oil company). Research on new and renewable energy comes under the purview of the Ministry of Science, Technology, and the Environment, and the Ministry of Primary Industriesthrough the Standards and Industrial Research Institute, the Palm Oil Research Institute of Malaysia, and the Forest Research Institute of Malaysia.

The government has adopted three key objectives that constitute a framework for programs in the energy sector:

- A supply objective to provide adequate and secure energy supply

- A utilization objective to promote efficient energy use and to discourage nonproductive and wasteful patterns of energy consumption 
- An environmental objective to ensure that in achieving the previous two objectives the environment is not neglected.

Malaysia's energy policy is designed to promote and support the growth and development of the economy, particularly industrialization. The government adopted a four-fuel policy based on hydropower, natural gas, petroleum, and coal to encourage energy conservation and diversification. The greatest emphasis has been placed on natural gas and hydropower because Malaysian coal resources are mainly low-quality lignite. It is now mandatory to conduct an environmental impact assessment on all new energy projects.

\section{Energy Efficiency and Conservation}

Malaysia has been involved in energy conservation since 1980. At that time a Working Committee (with METP as secretariat) conducted a national awareness campaign on energy conservation by organizing exhibitions and seminars and by using various communication media. Among the programs supported is the replacement of conventional lamps with sodium vapor units.

The Malaysian government promotes energy conservation through a number of agencies, and a number of surveys and studies have been performed that have lead to a variety of actions.

Some successes in energy conservation include

- 1980 -National awareness campaign on conservation (exhibitions, seminars, pamphlets, and advertisements)

- 1982-Formation of the Energy Management and Conservation Committee by the Federation of Malaysian Manufacturers

- 1983-Energy audits in factories funded by the United Nations Industrial Development Organization (UNIDO), the World bank, and PETRONAS

- 1985-Studies on four high-rise buildings funded by the Commonwealth Heads of Government

- 1986-Energy audits of 15 high-rise buildings

- $\quad$ 1987-Feasibility study on conservation in a palm oil processing plant

- 1988 - Training courses on energy audits for the commercial sector

- 1989-Publication of Guidelines for Energy Efficiency in Buildings.

The 1983 work conducted with UNIDO et al. on energy use in factories indicated that there were very few instances of actual energy conservation activities taking place. Measurement equipment and control equipment either were not provided or were not repaired. Specific recommendations were provided, including specific changes in operations that would reduce energy consumption. Opportunities for waste-heat recovery also were identified. Electrical consumption in most factories was found to have a relatively poor power factor. 
Beginning in 1985, the METP offered a series of seminars and training courses in conjunction with other organizations such as the Federation of Malaysian Manufacturers. Other organizations also sponsored training sessions and seminars.

In 1987, METP conducted a survey of industry and found that $47 \%$ of the respondents already had invested in energy-saving measures. In general, the investments had been made by the larger firms, and most investments were small.

The government selected the commercial and buildings sector for an energy-efficiency initiative, partly because of the diversity in the industrial sector. A Guidelines for Energy Efficiency in Buildings program was begun in December 1989. Other government activities included the formation of a Core Group for METP audit programs that is intended to increase expertise and continue audits without foreign assistance. Additional survey work, including industrial audits, is being conducted as well.

The fifth Malaysian Plan contemplated funding an Energy Conservation Center in Malaysia. The Standards and Industrial Research Institute of Malaysia and the Ministry of Domestic Trade also have examined the regulations and standards for appliances. Malaysia participates in the ASEAN-United States project on energy conservation in buildings. Energy audit equipment and control software was purchased.

The public sector funds at least $90 \%$ of the new and renewable energy projects in Malaysia. Most of these projects use either mini-hydroelectric or photovoltaic technologies. NEB implemented the first pilot project in 1983 with the remote electrification of Langkawi island. Since then, the Malayan railway, the Ministry of Education, the Marine Department, the Federal Land Development Authority, and Syarakat Telekom have used photovoltaics for remote power.

Malaysia has a sizeable potential to use biomass energy. The Malaysian National Committee estimates that $12 \%$ of the total energy supply comes from biomass. Energy from palm oil mills, rice plants, and animal dung could exceed 90 million barrels of oil equivalent. Pilot projects on biomass focus on disposing agricultural waste. Cogeneration capacity has been used in palm oil processing mills.

Large hydroelectric projects provide $1,020 \mathrm{MW}$, and there is a potential for an additional capacity of $29,000 \mathrm{MW}$. A government-funded mini-hydro program to supply rural electricity has commissioned 16 projects and has identified 125 others. By the year 2000 , mini-hydro will be a significant provider of electricity to rural areas.

The Financing of Energy Services for Small-scale Energy Users (FINESSE) identified six projects for possible financing. The projects included efficient lighting, an energy management system for an air conditioning factory, an energy audit and management service for commercial buildings, solar hot water for residential users, solar hot water for commercial users, and charcoal production in rural areas. FINESSE proposed a five-year financing arrangement to provide $90 \%$ of the customer's financing.

Bibliography

Correspondence from the Ministry of Energy, Telecommunications, and Posts

Integrated Energy Analysis for Malaysia Using the ENPEP Model, July 1991 
Finesse Workshop, Financing of Energy Services for Small-Scale Energy Users, Country Market Study-Malaysia; Salim Sairan, Masitah Hassan, Mohd Noh Dalimin, Nik Rahimah Nik Yacob, Mohd Zamzam Jaafar, Asian and Pacific Development Centre; October, 1991

Malaysia Asia Pacific Energy Series Country Report; U.S. Department of Energy; November 1988 


\begin{tabular}{l|l}
\hline Title: Feasibility Study on Conservation in \\
Palm Oil
\end{tabular}

\begin{tabular}{|c|c|}
\hline Title: Energy Audits & Project Type: Audit \\
\hline $\begin{array}{l}\text { Organization: United Nations Economic Social } \\
\text { Commission for Asia and the Pacific } \\
\text { (UN/ESCAP) }\end{array}$ & Date: 1985 to 1986 \\
\hline End-use Sector: Industry & Affiliated/Future Projects: None \\
\hline $\begin{array}{l}\text { Description: Industrial energy audits were } \\
\text { prepared covering } 30 \text { industries. }\end{array}$ & Technology: N/A \\
\hline Results: N/A & $\begin{array}{l}\text { Reference: Overview of Energy Conservation } \\
\text { Activities }\end{array}$ \\
\hline
\end{tabular}

\begin{tabular}{l|l|}
\hline Title: Energy Audit Program & Project Type: Audit \\
Organization: National Electricity Board (with & Date: 1983 \\
\hdashline End-use Sector: Industry & Affiliated/Future Projects: None \\
\hdashline Description: An energy audit program studying \\
nine factories.
\end{tabular}




\begin{tabular}{l|l|}
\hline Title: Survey of Manufacturers on Industrial \\
Energy Efficiency \\
\hdashline Organization: Ministry of Energy \\
Telecommunications, and Post (METP) \\
\hdashline End-use Sector: Industry \\
Description: Questionnaires were sent to \\
700 members of Federation of Malaysian \\
Manufacturers; 255 were received and analyzed. \\
\hdashline Results: About 47\% had already invested in \\
energy-saving measures, small and large. About \\
50\% planned some measures for the next three \\
years (typically those who had already invested).
\end{tabular}

\begin{tabular}{|l|l|}
\hline Title: Energy Audits in Selected Plants & Project Type: Audit \\
\hline Organization: METP & Date: In progress \\
\hdashline End-use Sector: Industry & Affiliated/Future Projects: None \\
\hdashline Description: About 30 screening audits were \\
carried out.
\end{tabular}

\begin{tabular}{|c|c|}
\hline Title: Energy Use in Industries & Project Type: Survey \\
\hline $\begin{array}{l}\text { Organization: Standards and Industrial } \\
\text { Research Institute of Malaysia (SIRIM) }\end{array}$ & Date: 1985 \\
\hline End-use Sector: Industry & $\begin{array}{l}\text { Affiliated/Future Projects: Energy } \\
\text { Consumption Reference established in } 1986 .\end{array}$ \\
\hline $\begin{array}{l}\text { Description: Questionnaires were sent to } \\
40 \text { industries to establish energy consumption. }\end{array}$ & Technology: N/A \\
\hline $\begin{array}{l}\text { Results: The return rate was } 10 \% \text { because of } \\
\text { the survey's request for detailed information on } \\
\text { energy use and production. }\end{array}$ & $\begin{array}{l}\text { Reference: ASEAN-EC Energy Conservation } \\
\text { Seminar, December } 1987 \text {, p. } 32\end{array}$ \\
\hline
\end{tabular}




\begin{tabular}{|c|c|}
\hline Title: Energy Consumption Reference & Project Type: Survey \\
\hline $\begin{array}{l}\text { Organization: Ministry of Energy, } \\
\text { Telecommunications, and Post (METP) }\end{array}$ & Date: 1986 \\
\hline End-use Sector: Industry & Affiliated/Future Projects: None \\
\hline $\begin{array}{l}\text { Description: Questionnaires were sent to } 200 \\
\text { factories in a continuing attempt to survey } \\
\text { industrial energy use. }\end{array}$ & Technology: N/A \\
\hline Results: The return rate was $40 \%$. & $\begin{array}{l}\text { Reference: ASEAN-EC Energy Conservation } \\
\text { Seminar, December } 1987 \text {, p. } 32\end{array}$ \\
\hline
\end{tabular}

\begin{tabular}{|c|c|}
\hline $\begin{array}{l}\text { Title: Effects of Energy Conservation on Fuel } \\
\text { Use }\end{array}$ & Project Type: Study/demonstration \\
\hline $\begin{array}{l}\text { Organization: National Electricity Board of } \\
\text { Malaysia (NEB) }\end{array}$ & Date: In progress \\
\hline End-use Sector: Industry & Affiliated/Future Projects: None \\
\hline $\begin{array}{l}\text { Description: The study will quantify the effects } \\
\text { of energy conservation on the use of oil, gas, } \\
\text { and electricity. }\end{array}$ & Technology: N/A \\
\hline Results: N/A & $\begin{array}{l}\text { Reference: ASEAN-EC Energy Conservation } \\
\text { Seminar, December } 1987, \text { p. } 32\end{array}$ \\
\hline
\end{tabular}

\begin{tabular}{|l:l|}
\hline Title: Technical Working Group on Energy \\
Conservation in Industries (TWGECI)
\end{tabular}




\begin{tabular}{|c|c|}
\hline $\begin{array}{l}\text { Title: Drying Technology in Agricultural } \\
\text { Produce in Malaysia: Solar Option }\end{array}$ & Project Type: Study/demonstration \\
\hline $\begin{array}{l}\text { Organization: Malaysian Agricultural Research } \\
\text { and Development Institute (MARDI), Standard } \\
\text { Industrial Research Institute of Malaysia } \\
\text { (SIRIM) }\end{array}$ & Date: 1987 \\
\hline End-use Sector: Industry & Affiliated/Future Projects: None \\
\hline $\begin{array}{l}\text { Description: A study to determine the status of } \\
\text { drying technologies and the potential for use of } \\
\text { solar energy in the drying process }\end{array}$ & Technology: N/A \\
\hline $\begin{array}{l}\text { Results: The study concludes that new } \\
\text { technology is necessary to reduce the cost of } \\
\text { drying. If the cost of energy is high and } \\
\text { unpredictable, solar looks promising. }\end{array}$ & $\begin{array}{l}\text { Reference: Proceedings of the } 1989 \text { Congress } \\
\text { of the International Solar Energy Society, } \\
\text { M. Yusof Othman et. al., Solar Energy Research } \\
\text { Group, Universiti Kebangsean, Malaysia }\end{array}$ \\
\hline
\end{tabular}

\begin{tabular}{l:l|}
\hline Title: Study on the Incidence of Electrical \\
Appliances in Urban Households
\end{tabular}




\begin{tabular}{|l|l|}
\hline $\begin{array}{l}\text { Title: Seminar on Energy Efficiency and } \\
\text { Conservation }\end{array}$ & Project Type: Education/information \\
\hdashline $\begin{array}{l}\text { Organization: Malaysian government with } \\
\text { help of United Nations Economic and Social } \\
\text { Commission for Asia and the Pacific } \\
\text { (UN/ESCAP) }\end{array}$ & Date: 1989 \\
\hdashline End-use Sector: All sectors & Affiliated/Future Projects: None \\
\hdashline $\begin{array}{l}\text { Description: Training, demonstration, and } \\
\text { seminar on energy conservation. }\end{array}$ & Technology: N/A \\
\hdashline Results: N/A & $\begin{array}{l}\text { Reference: Overview of Energy Conservation } \\
\text { Activition }\end{array}$ \\
\hline
\end{tabular}

\begin{tabular}{|l|l|}
\hline Title: Guidelines for Energy Efficiency in \\
Buildings
\end{tabular}

\begin{tabular}{|l|l|}
\hline Title: Training Course on Energy Audit and & Project Type: Education/information \\
Management & Date: 1988 \\
\hdashline Organization: Malaysian government & Affiliated/Future Projects: None \\
\hdashline End-use Sector: Commercial building & Technology: N/A \\
\hdashline Description: Training course was conducted at & \\
a local university. & Reference: Onerview of Energy Conservation \\
\hdashline Results: N/A & Activities \\
\hline
\end{tabular}




\begin{tabular}{|c|c|}
\hline $\begin{array}{l}\text { Title: ASEAN-US Project on Energy } \\
\text { Conservation in Building }\end{array}$ & Project Type: Education/information \\
\hline Organization: Malaysian government & Date: 1985 \\
\hline End-use Sector: Commercial building & Affiliated/Future Projects: None \\
\hline $\begin{array}{l}\text { Description: Local researchers carried out } \\
\text { studies and attended courses on building energy } \\
\text { efficiency. }\end{array}$ & Technology: N/A \\
\hline Results: N/A & $\begin{array}{l}\text { Reference: Overview of Energy Conservation } \\
\text { Activities }\end{array}$ \\
\hline
\end{tabular}

\begin{tabular}{|c|c|}
\hline Title: Energy Audits & Project Type: Audit \\
\hline Organization: Malaysian government & Date: 1985 \\
\hline End-use Sector: Commercial building & Affiliated/Future Projects: None \\
\hline $\begin{array}{l}\text { Description: Energy audits of } 15 \text { high-rise } \\
\text { buildings around Kuala Lumpur. }\end{array}$ & Technology: N/A \\
\hline Results: Unclear & $\begin{array}{l}\text { Reference: Overview of Energy Conservation } \\
\text { Audits }\end{array}$ \\
\hline
\end{tabular}

\begin{tabular}{|c|c|}
\hline $\begin{array}{l}\text { Title: Study Regarding Center for the National } \\
\text { Use of Energy in Malaysia }\end{array}$ & Project Type: Study/demonstration \\
\hline $\begin{array}{l}\text { Organization: United Nations Development } \\
\text { Programme (UNDP) }\end{array}$ & Date: 1989 \\
\hline End-use Sector: All sectors & Affiliated/Future Projects: None \\
\hline $\begin{array}{l}\text { Description: A UNDP mission looked into the } \\
\text { possibility of setting up a center that would } \\
\text { include training and energy audits for industry, } \\
\text { among other recommendations. }\end{array}$ & Technology: N/A \\
\hline $\begin{array}{l}\text { Results: Report prepared but no funding } \\
\text { available for implementation. }\end{array}$ & $\begin{array}{l}\text { Reference: Overview of Energy Conservation } \\
\text { Activity }\end{array}$ \\
\hline
\end{tabular}




\section{New Zealand}

New Zealand covers two islands in the South Pacific having a total land area of some $269,000 \mathrm{~km}^{2}$ and a population of approximately 3.4 million. The government is a parliamentary democracy.

New Zealand's gross domestic product (GDP) reached US\$42,769 million in 1990, up from US\$5,640 in 1965. This represents an annual gross national product (GNP) increase of $1.9 \%$ for 1980 to 1990. The GDP came from the following market sectors: agriculture (9\%), industry (27\%), and services (65\%); within industry, manufacturing comprised $19 \%$ of GDP. The GDP rose $0.4 \%$ in 1990 . A GDP growth of $1.5 \%$ was predicted for 1991 .

In 1990, exports totaled US\$9,045 million and imports totaled US\$9,466 million. Over the period 1980 to 1990 , this represents an average annual growth rate for exports of $3.4 \%$ and an average annual growth rate for imports of $3.6 \%$.

The slowdown in the world economy severely impacted New Zealand's commodity exports. Prices of dairy and wool products fell sharply, and farm profits weakened. The industry endured because of an increase in planting and livestock. Falling prices for New Zealand's commodity exports have been offset by a $10 \%$ increase in manufactured exports. However, unemployment has risen to $9.9 \%$ in 1991, and modest wage increases are expected for 1991 to 1992.

The average rate of inflation was $10.5 \%$ from 1980 to 1990.

The government has reacted to the slow economic growth with a stringent fiscal policy. The Pacific Economic Outlook predicts that the New Zealand economy will remain sluggish through 1992. Unemployment should remain around $9 \%$, and average annual earnings are expected to rise.

\section{Energy Use and Policy Issues}

In 1989, New Zealand's total energy consumption reached 14.9 million tons of oil equivalent (Mtoe). This was supplied by oil (30.9\%), coal $(9.4 \%)$, gas (23.5\%), and hydro (36.2\%). By the year 2000 , total energy consumption is expected to rise to 18.1 Mtoe.

Per capita energy consumption equaled 4,971 kilograms of oil equivalent (kgoe) in 1990, up from $2,622 \mathrm{kgoe}$ in 1965 . For the period of 1980 to 1990 , energy consumption grew at an annual rate of $5.4 \%$. For the previous 15 years (1965 to 1980), energy consumption grew at an annual rate of $3.6 \%$.

The people and the government have demonstrated strong apprehension about the effects of energy production and consumption on the environment. There is particular concern about the effect of greenhouse gases.

The overall energy policy is "to ensure the continuing availability of energy services, at the lowest cost to the economy as a whole, consistent with sustainable development."

New Zealand has made a commitment to energy efficiency that is characterized by the following:

- Dramatic institutional reforms, including the deregulation of markets to permit inter-fuel competition 
- Reforms that ensure that the actual costs of energy production, conversion, and distribution are reflected in consumer prices

- Acceptance of the economic, environmental, and social equity associated with more efficient energy use

- Use of market facilitation techniques to facilitate access to information rather than regulations.

\section{Alternative Fuels}

New Zealand developed a policy to promote alternative fuels for a number of reasons. First, the fluctuating price of oil ripples through the economy, causing uncertainty and reduced economic growth. Second, there is an indigenous supply of natural gas available for motor fuel. Third, the population is concerned about the effects of automobiles on the environment. Fourth, the private sector has a considerable capacity to produce large volumes of liquefied petroleum gas (LPG).

The government of New Zealand first promoted the use of compressed natural gas (CNG) as an alternative fuel after the oil shock in the early eighties. The government established regulatory controls to guide the industry and set a target of 50\% self-sufficiency in transport fuels by 1990 .

The CNG industry struggled in the early eighties because of a lack of supply infrastructure and demand from consumers. The cost of converting a regular gasoline-powered vehicle to CNG was expensive, and the payback time was long. In addition to the demand problem, there was no distribution network for the fuel. To overcome these obstacles, the government provided consumers with low interest loans to convert automobiles to CNG. As a result, Caltex invested in a distribution network for both the North and South islands.

As a result of the government support and the distribution network, CNG use has grown significantly. The private sector has developed an LPG network and started marketing the fuel. The government withdrew its support of CNG (feeling there was significant support from the private sector), and the industry collapsed. LPG use remained strong because the private sector developed the whole industry, including its own marketing organization.

The story of alternative fuels in New Zealand shows the important role government plays in the delicate balance between the success and failure of an industry. Any change in policy can have tremendous implications throughout the industry. Today, more than 150,000 cars (approximately 10\% of the vehicles in New Zealand) run on LPG or CNG.

\section{Energy Efficiency and Conservation}

Most renewable energy and conservation activity in New Zealand concentrates on improving existing installations. New Zealand's expertise lies in conservation using control systems and energy-efficient power plants. Suppliers of energy-efficient products are emerging, including one manufacturer of high-efficiency light bulbs. Other conservation activities include companies that provide energy audits and consulting, cogeneration system manufacturing, and heating and heat recovery systems. There is a small solar hot water industry and a few distributors of wind, photovoltaic, and micro-hydro systems.

A recent institutional reform (October 1992) is the establishment of The Energy Resources Monitoring and Conservation Authority (ERMCA), which has as its purpose the promotion of conserving the 
energy reserves of New Zealand. Conservation is defined to mean the management of the nation's energy resources such that their productivity is increased through the adoption of energy-efficient practices and technology, and that economic, social, and environmental considerations are taken into account. ERMCA will be an independent authority charged with the implementation of efficiency practices and will be the international liaison on efficiency issues. For greenhouse gas and wider policy issues, ERMCA will be supported by officials from the Ministries for the Environment and Commerce.

The following are functions of the authority:

- To develop, implement, and promote strategies for energy conservation

- To advise the government and the energy industry on matters relating to the development, implementation, and promotion of those conservation strategies

- To monitor known energy sources, their use, and the investigation of potential sources and applications, together with the economic, social, and environmental impacts, in both the short and long term.

The New Zealand government conducted a five-year study, titled Design to the Sun, aimed at reducing energy consumption by using energy conservation and passive solar technology. The program's achievements include the following:

- Design to the Sun manual for designers and architects

- Design to the Sun two-day workshops around the country

- Demonstration programs in 18 conventional homes and 10 solar homes

- Monitoring of energy consumption and comfort level in demonstration homes

- Technical and market assessments from a consumer and national perspective

- Market research on homeowner and builder attitudes

- Solar subdivision for Blenheim.

Design to the Sun staff worked with the Housing Corporation of New Zealand to demonstrate many of the homes in the program. They also compared construction techniques and building materials for passive solar homes. The results show $40 \%$ to $50 \%$ lower heating bills and very happy residents. Unfortunately, the Passive Solar Market Study showed low levels of consumer awareness.

The Department of Commerce has set up a branch to address energy conservation and energy efficiency. Energy Management (EM) provides policy advice on energy management initiatives and promotes energy management to the government and the private sector. 
The following are EM's goals:

- To make businesses more competitive by maximizing energy productivity

- To reduce the waste of energy resources

- To foster increased national security of energy supplies

- To protect the natural environment.

EM has had several significant accomplishments since 1988:

- Nine major energy-saving initiatives in the government

- Twenty-six projects demonstrating the energy savings and performance of new technologies (projects focused on control systems and improving efficiency in conventional energy generation)

- Savings of NZ\$1.5 million in reduced energy spending by the government

- Establishment of a major information program, including a bimonthly newspaper on energy management issues targeted to senior and middle management; an annual reference directory of the energy supply and energy management industries; and several publications for the domestic sector

- A showcase project in one community to demonstrate the value of community education in energy management

- Acceptance of a recommendation to include energy-efficiency performance standards in the proposed building codes.

\section{Bibliography}

Energy Management Consultancy Service; Energy Management

Energy Management Energy \& Resources Division Ministry of Commerce Business Plan 1990-1991

Energy Management News; Energy \& Resources Division, Ministry of Commerce; May 1991

Energy Auditing; Energy Management

Energy Management Demonstration Programme, Project Profile 1-25, Case Studies 1-5; Blenheim Borough Council

Energy Management and the Greenhouse Effect, A Background Paper on Energy Management and the 1988 Toronto Goal; C. Turbott, F. Pool and G. Vickers, Energy Management, Energy and Resources Division, Ministry of Commerce; January 1991

Houses Designed for New Zealand Sun; D.R. Brewer

The Energy Management Yearbook 1992; Energy Management 
Title: Conservation for Commercial Laundry Machines

Organization: Energy Management

Demonstration Programme (EMDP), Hawkes

Bay Hospital Board

End-use Sector: Commercial building

Description: Six commercial laundry machines at a hospital were retrofitted with Washtec controllers. The systems were monitored.

Results: The total savings were $\$ 8,000$ per year. The expected payback period was 16 months and the controllers reduced the wash time by 20 minutes.
Project Type: Study/demonstration

Date: 1989

Affiliated/Future Projects:

Technology: Conservation, Washtec LC101 controllers

Reference: EMDP Report \#4 Title: Flue Gas Economizers at Laundry
Locations

Organization: EMDP, New Zealand Towel Supply, Newmarket Laundry

End-use Sector: Commercial building

Description: Waste heat from exhaust gases preheat incoming water. The resulting hot water is fully potable.

Results: Payback period of 2 years.
Project Type: Study/demonstration

Date: 1990

Affiliated/Future Projects: High-efficiency hot water generators also were installed at New Zealand Towel Supply.

Technology: Conservation, flue gas recirculator, Combustion Control Ltd.

Reference: EMDP Project Reports \#15, \#16 and \#19

\begin{tabular}{l:l}
\hline Title: Energy Management and Control System & Project Type: Study/demonstration \\
\hdashline Organization: Ministry of Agriculture and & Date: 1988 \\
Fisheries, (MAF) Energy Management \\
Demonstration Programme \\
\hdashline End-use Sector: Commercial building & Affiliated/Future Projects: \\
\hdashline Description: MAF studied the peak/nonpeak \\
tariffs and installed an energy management \\
control system.
\end{tabular}




\begin{tabular}{|l:l|}
\hline Title: High-Efficiency Steam Blancher & Project Type: Study/demonstration \\
\hdashline Organization: Wattie Frozen Foods, EMDP & Date: 1988 \\
\hdashline End-use Sector: Industry & Affiliated/Future Projects: \\
Description: Wattie Foods installed a more & Technology: Conservation, a high velocity \\
efficient blancher for use in industrial food \\
processing.
\end{tabular}

\begin{tabular}{|c|c|}
\hline $\begin{array}{l}\text { Title: Improved Fuel Combustion Efficiency in } \\
\text { Boilers }\end{array}$ & Project Type: Study/demonstration \\
\hline $\begin{array}{l}\text { Organization: Taumarunui Hospital, Fairfield } \\
\text { College, EMDP }\end{array}$ & Date: 1988 \\
\hline End-use Sector: Commercial building & $\begin{array}{l}\text { Affiliated/Future Projects: The hospital } \\
\text { installed compact fluorescent light bulbs and } \\
\text { achieved a payback of } 3.6 \text { years. }\end{array}$ \\
\hline $\begin{array}{l}\text { Description: Flue gas re-circulator improves } \\
\text { burning efficiency, allows different types of } \\
\text { coal, and reduces cost at the hospital. }\end{array}$ & $\begin{array}{l}\text { Technology: Conservation, flue gas re- } \\
\text { circulation. }\end{array}$ \\
\hline $\begin{array}{l}\text { Results: Project resulted in a savings at } \\
\text { Taumarunui Hospital of } \$ 8,000 \text { per year and a } \\
\text { payback time of } 1.5 \text { years. Savings of } \$ 430 \text { per } \\
\text { year were achieved at Fairfield College. }\end{array}$ & $\begin{array}{l}\text { Reference: EMDP Project Report \#6 and \#8, } \\
\text { Case Study \#1 }\end{array}$ \\
\hline
\end{tabular}

\begin{tabular}{|c|c|}
\hline $\begin{array}{l}\text { Title: High-Efficiency Gas Heater for Central } \\
\text { Heating }\end{array}$ & Project Type: Study/demonstration \\
\hline $\begin{array}{l}\text { Organization: EMDP, Gas Development } \\
\text { Center }\end{array}$ & Date: 1989 \\
\hline End-use Sector: Residential building & Affiliated/Future Projects: \\
\hline $\begin{array}{l}\text { Description: EMDP is testing and monitoring a } \\
\text { furnace having an efficiency of } 97 \% \text {. }\end{array}$ & Technology: Conservation, gas furnace \\
\hline Results: Expected payback of 5 years. & Reference: EMDP Project Report \#7 \\
\hline
\end{tabular}




\begin{tabular}{|l:l|}
\hline Title: Gas Boiler Conversion & Project Type: Study/demonstration \\
\hdashline Organization: EMDP, Huttons Kiwi Ltd. & Date: 1989 \\
\hdashline End-use Sector: Commercial building & Affiliated/Future Projects: \\
\hdashline Description: New Zealand-based Energy \\
Services Co. developed a waste heat recovery \\
system that can be added to existing modules. It \\
condenses water vapor and recovers the latent \\
heat.
\end{tabular}

\begin{tabular}{|c|c|}
\hline $\begin{array}{l}\text { Title: Energy-Efficient Supermarket } \\
\text { Refrigeration }\end{array}$ & Project Type: Study/demonstration \\
\hline $\begin{array}{l}\text { Organization: EMDP, Masterton } \\
\text { Supermarkets, Food Technology Research } \\
\text { Center }\end{array}$ & Date: 1989 to 1990 \\
\hline End-use Sector: Commercial building & Affiliated/Future Projects: \\
\hline $\begin{array}{l}\text { Description: EMDP conducted a study of } \\
\text { parallel rack refrigerators. The units were } \\
\text { retrofitted with waste heat recovery systems, } \\
\text { switches, and other innovations. Waste heat is } \\
\text { used for space heating. }\end{array}$ & $\begin{array}{l}\text { Technology: Conservation, switches and } \\
\text { monitoring }\end{array}$ \\
\hline $\begin{array}{l}\text { Results: The project saved NZ } \$ 45,000 \text { a year } \\
\text { and could be repaid within } 3 \text { years. }\end{array}$ & Reference: EMDP Project Report \#9 \\
\hline
\end{tabular}

\begin{tabular}{|c|c|}
\hline Title: Blast Freezer's Variable Speed Fans & Project Type: Study/demonstration \\
\hline Organization: EMDP, AFFCO NZ Ltd. & Date: 1991 \\
\hline End-use Sector: Industry & Affiliated/Future Projects: \\
\hline $\begin{array}{l}\text { Description: A computer-controlled fan } \\
\text { regulated freezing in a meat plant. }\end{array}$ & $\begin{array}{l}\text { Technology: Conservation. Fan's airflow is } \\
\text { proportional to the fan speed, but power } \\
\text { consumption is proportional to the cube of the } \\
\text { fan speed. }\end{array}$ \\
\hline $\begin{array}{l}\text { Results: Project resulted in a } 44 \% \text { energy } \\
\text { savings and a payback period of } 2.1 \text { years. }\end{array}$ & Reference: EMDP Project Report \#20 \\
\hline
\end{tabular}




\begin{tabular}{|c|c|}
\hline Title: Dual Duct HVAC Systems & Project Type: Study/demonstration \\
\hline Organization: EMDP, Aukland Hospital & Date: 1989 \\
\hline End-use Sector: Commercial building & Affiliated/Future Projects: \\
\hline $\begin{array}{l}\text { Description: The air conditioning system of } \\
\text { Aukland Hospital was upgraded with a variable } \\
\text { speed fan. }\end{array}$ & $\begin{array}{l}\text { Technology: Conservation, variable-speed } \\
\text { HVAC fan }\end{array}$ \\
\hline $\begin{array}{l}\text { Results: Project resulted in an energy savings } \\
\text { of } \$ 6,022 \text { and a payback time of } 4 \text { years. The } \\
\text { hospital also learned about the system and made } \\
\text { other improvements for further savings. }\end{array}$ & Reference: EMDP Project Report \#10 \\
\hline
\end{tabular}

\begin{tabular}{|c|c|}
\hline Title: Swimming Pool Insulation Covers & Project Type: Study/demonstration \\
\hline Organization: EMDP, Moana Pool & Date: 1992 \\
\hline End-use Sector: Commercial building & Affiliated/Future Projects: \\
\hline $\begin{array}{l}\text { Description: EMDP installed covers on three } \\
\text { pools having a total area of } 138 \mathrm{~m}^{2} \text {. }\end{array}$ & $\begin{array}{l}\text { Technology: Conservation, insulation with } \\
\text { MacBall Insulating Pool Blanket }\end{array}$ \\
\hline $\begin{array}{l}\text { Results: Payback time of } 30 \text { months was } \\
\text { achieved. The reduced humidity also will reduce } \\
\text { building maintenance costs. }\end{array}$ & Reference: EMDP Project Report \#23 \\
\hline
\end{tabular}

\begin{tabular}{|l:c|}
\hline $\begin{array}{l}\text { Title: Insulation Blankets for Hot Water } \\
\text { Heaters }\end{array}$ & Project Type: Study/demonstration \\
\hdashline Organization: EMDP, McCracken's Farm & Date: 1991 \\
\hdashline $\begin{array}{l}\text { End-use Sector: Commercial, residential } \\
\text { buildings }\end{array}$ & Affiliated/Future Projects: \\
\hdashline $\begin{array}{l}\text { Description: Insulating hot water heaters for } \\
\text { residential or commercial use saved } 46 \% \text { of the } \\
\text { electricity costs. }\end{array}$ & Technology: Conservation, insulation \\
\hdashline Results: Payback period was less than 1 year. & Reference: EMDP Project Report \#24 and \#25 \\
\hline
\end{tabular}




\begin{tabular}{|c|c|}
\hline Title: Valve Insulation & Project Type: Study/demonstration \\
\hline Organization: EMDP, Newmarket Laundry & Date: 1989 \\
\hline End-use Sector: Commercial building & Affiliated/Future Projects: \\
\hline $\begin{array}{l}\text { Description: Valve insulation blankets were } \\
\text { developed by Bestobell for easy removal and } \\
\text { durability. }\end{array}$ & Technology: Conservation, insulation \\
\hline $\begin{array}{l}\text { Results: Newmarket Laundry installed } 14 \text { valve } \\
\text { blankets costing } \$ 64.99 \text {. Payback time was } 9.8 \\
\text { months. }\end{array}$ & Reference: EMDP Project Report \#12 \\
\hline
\end{tabular}

\begin{tabular}{|c|c|}
\hline Title: Victoria University Lighting Installation & Project Type: Study/demonstration \\
\hline $\begin{array}{l}\text { Organization: Government Energy } \\
\text { Management Services, Victoria University }\end{array}$ & Date: 1991 \\
\hline End-use Sector: Commercial building & $\begin{array}{l}\text { Affiliated/Future Projects: Taumarunui } \\
\text { Hospital installed compact fluorescent lights for } \\
70 \% \text { savings. Other initiatives at Victoria } \\
\text { University saved } \$ 200,000 \text {. }\end{array}$ \\
\hline $\begin{array}{l}\text { Description: Victoria University's library } \\
\text { installed high-efficiency reflectors, compact } \\
\text { fluorescent lights, and lighting timers in the } \\
\text { stacks. }\end{array}$ & Technology: Conservation, lighting \\
\hline $\begin{array}{l}\text { Results: Energy consumption was reduced } 65 \% \\
\text { or } \$ 16,000 \text { per year. }\end{array}$ & Reference: EMDP Case Study \#3 \\
\hline
\end{tabular}




\begin{tabular}{|c|c|}
\hline $\begin{array}{l}\text { Title: Energy Management Demonstration } \\
\text { Programme }\end{array}$ & Project Type: Policy assessment; study/demo \\
\hline Organization: Ministry of Energy & Date: Ongoing \\
\hline End-use Sector: Commercial building & $\begin{array}{l}\text { Affiliated/Future Projects: EMCS publishes a } \\
\text { product catalog for energy services and systems. }\end{array}$ \\
\hline $\begin{array}{l}\text { Description: EMDP helps individual } \\
\text { companies save money and energy. The pro- } \\
\text { gram is designed to encourage collaboration } \\
\text { between energy suppliers and consumers. } \\
\text { Projects use extensive monitoring and control } \\
\text { technologies. }\end{array}$ & $\begin{array}{l}\text { Technology: Conservation. EMDP supports } \\
\text { New Zealand conservation industry and has } \\
\text { developed expertise in automated/computer } \\
\text { control systems for energy. }\end{array}$ \\
\hline $\begin{array}{l}\text { Results: EMDP has completed successfully } \\
\text { more than } 25 \text { projects, case studies for industry, } \\
\text { and an information campaign for conservation. } \\
\text { It provides services, including walk-through } \\
\text { energy surveys, energy technology advice, tariff } \\
\text { analysis, feasibility studies, and energy- } \\
\text { efficiency plans. }\end{array}$ & Reference: EMDP Annual Report \\
\hline
\end{tabular}

\begin{tabular}{|l|l|}
\hline Title: 'eta' Awards & Project Type: Policy assessment \\
\hdashline Organization: Energy Management & Date: Ongoing \\
\hdashline $\begin{array}{l}\text { End-use Sector: Industry; commercial, } \\
\text { residential buildings }\end{array}$ & Affiliated/Future Projects: \\
\hdashline Description: The Ministry of Commerce gives \\
awards for energy efficiency and productivity in \\
industry.
\end{tabular}




\begin{tabular}{l:l}
\hline $\begin{array}{l}\text { Title: Residential Energy Code-A New } \\
\text { Zealand Proposal }\end{array}$ & Project Type: Policy assessment \\
\hdashline Organization: University of Auckland (School \\
of Architecture)
\end{tabular}

Title: Design and Construction of Low Energy
Housing

\begin{tabular}{|l:c|}
\hline Title: Low Energy Library for Nelson City & Project Type: Study/demonstration \\
\hdashline Organization: EMDP, Nelson City Council. & Date: 1989 \\
Victoria University's Energy Research Group & \\
\hdashline End-use Sector: Commercial building & Affiliated/Future Projects: Unknown \\
\hdashline Description: The architects worked with the & Technology: Passive solar \\
EMDP, and Victoria University designed a new & \\
library for Nelson City. & \\
\hdashline Results: The library will reduce capital costs & Reference: EMDP Project Report \\
by $\$ 40,000$ and will achieve energy savings of & \\
$\$ 4,000$ per year.
\end{tabular}




\section{People's Republic of China}

China has a population of more than 1 billion people, an undeveloped infrastructure, and growing energy needs. At the present time, there is a severe energy shortage caused by increased economic activity both in urban and rural communities. This energy shortage is especially acute in rural areas, where $80 \%$ of the households rely on firewood as the major source of cooking fuel.

To meet the growing energy demand, China has maintained its investment in new energy plants and has championed conservation and renewable energy.

According to the constitution, the People's Republic of China is "a socialist state under the people's democratic dictatorship led by the working class." Structurally, two separate bodies govern the country-the National People's Congress and the State Council.

China's economy gained momentum in 1990. Spurred by a second year of record harvests, increased industrial output, and growing exports, China's gross national product (GNP) grew by 5\%. Inflation was $2.1 \%$. Foreign exchange reserves grew to US\$29 billion, which is equal to at least six months of imports.

China's gross domestic product (GDP) reached US $\$ 364,900$ million in 1990 , up from US $\$ 67,200$ million in 1965. This represents an average annual growth rate of $9.5 \%$ during 1980 to 1990 . The GDP came from the following market sectors: agriculture (27\%), industry (42\%), and services (31\%); within industry, manufacturing comprised 38\% of GDP. The GDP rose 5\% in 1990. A GDP growth of $5.7 \%$ was predicted for 1991 .

The eighth five-year plan (1991 to 1995) emphasizes development of agriculture, basic industry, transportation, and communications. The program calls for an economic system that combines the traditional centralized government planning with market forces. The government will continue to operate two-thirds of China's industry but will also allow private ownership.

The average rate of inflation was $5.8 \%$ from 1980 to 1990.

In 1990, exports totaled US\$62,091 million and imports totaled US\$53,345 million. Over the period 1980 to 1990 , this represents an average annual growth rate for exports of $11 \%$ and an average annual growth rate for imports of $9.8 \%$. China's main exports include apparel, toys, and telecommunications, and the main imports from the United States include aircraft, computers, fertilizer, and wood products. China's 1991 trade balance was US $\$ 8.1$ billion. The United States-China trade balance favored China by US\$12.8 billion.

The Chinese economy is in transition, changing from a planned economy to a market-driven economy. Although the initial outlook is optimistic, the central government has made little progress towards tighter macroeconomic control. The greatest fear is double-digit inflation, which has plagued the reform-minded administration in the past. There are ample opportunities for U.S. investors and exporters in certain sectors, but securing access to raw materials, credit, and the domestic market is difficult.

The Pacific Economic Outlook predicts growth in China will reach $6.8 \%$ in 1992. Imports will grow faster than exports. The inflation rate should remain around $6.4 \%$. 


\section{Energy Use and Policy Issues}

China began to utilize petroleum and natural gas as fuels as early as the fourth century B.C. Today, China possesses the third largest energy system in the world, which produced 1,016 million tons of coal equivalent in 1989. Since $1949,21.2 \%$ of the investment in the nation has been put to use in the energy sector. This caused a 9.7\% average annual growth rate in production between 1949 to 1989.

Per capita energy consumption equaled 598 kilograms of oil equivalent (kgoe) in 1990, up from 178 kgoe in 1965. For the period 1980 to 1990 , energy consumption grew at an annual rate of 5.6\%. For the years between 1965 and 1980, energy consumption grew at an annual rate of $9.8 \%$.

China's energy sector is dominated by the use of coal. The country has proven coal reserves totaling 901.5 billion tons. In 1988 , domestic consumption of coal reached 982.2 million tons; $25.6 \%$ of the coal generates power. The coal industry employs more than 7 million people. Because of the great reliance on coal, there are great pressures on the transportation system and the environment.

China exploits 233 oil fields and 68 gas fields. In 1989, it produced 137.65 MT of crude oil and 14.49 million cubic meters of natural gas. There are 37 medium-sized refineries that have a total processing capacity of $110 \mathrm{MT}$. In 1989 , the refineries processed $102.9 \mathrm{MT}$, which produced 20.65 MT of gasoline, 25.81 MT of diesel fuel, and 32.1 MT of fuel oil.

China's electric power industry has an installed capacity of 126.6 gigawatts (GW) (92 GW of thermal and $34.6 \mathrm{GW}$ hydroelectric). There are, however, significant power shortages, especially in some regions of the nation that lack hydropower or adequate coal transportation facilities.

In rural areas, about one-half of the energy use is commercial energy and one-half is noncommercial biomass. Approximately 236 million tons of firewood and 273 million tons of straw are used annually.

\section{Energy Efficiency and Conservation}

In the late seventies, China adopted several new policies to encourage energy efficiency and conservation and, thereby, reversed a long-standing trend of energy consumption growing 1.5 to 2 times more rapidly than the economy. The rapid growth of energy consumption was a result of the development of heavy industry, the lack of a rational pricing policy or other mechanism to balance supply and demand, and the general lack of attention given to resource use by national planning institutions. Since 1978, however, the rate of growth for energy has been only one-half that of the economy-a significant result.

In 1979 and 1980, Chinese energy experts were assembled in a series of meetings sponsored by the China Research Society. Out of these meetings came a new energy policy and new measures for energy conservation and efficiency. The proposed program was based on six major components:

1. Specific energy-efficiency requirements

2. Information campaigns

3. A shift to less energy-intensive industry

4. Price reform 


\section{Establishment of energy conservation centers}

6. Creation of investment funds for energy management and efficiency investments.

The government created a specific investment plan that had investment criteria based on the cost of producing 1 ton of coal-criteria that equated the cost of producing a unit of energy with the cost of saving a unit of energy. The original cost was calculated to be $\$ 340$ yuan per ton, and it has been revised as the cost of producing coal has increased over time. The State Planning Commission and the banks established an interest rate of $2.5 \%$ for energy conservation loans having a term of four to six years; the rate is about one-third lower than the prevailing rate at the time.

The government made loans for new equipment and modernization as well, and used pre-feasibility studies to identify projects that met the lending criteria. A total of 10 billion yuan were allocated to the projects in the sixth five-year plan; two-thirds of the funds came from the central government and one-third from local administrations and enterprises. As a result of the program, of the approximately 12 to 13 billion yuan invested in energy in China in 1981 to 1982, 2 billion yuan was explicitly devoted to saving energy.

The overall energy-savings accomplishments of the sixth five-year plan are estimated at 14 million tons of coal per year from the technology modernization program, at a cost of about 3.7 billion yuan or 260 yuan per ton per year. Capital construction programs averaged 620 yuan per ton per year. It is estimated that the annual growth rate for consumption was $4 \%$ and that it would have been $7 \%$ without the program.

To achieve improved energy efficiency four main technology areas have been identified:

1. Improving efficiency in the power industry through such measures as improving production management, reduction of transmission losses, and upgrading existing power equipment

2. Introducing high-efficiency fans, pumps, and electric motors into the Chinese market and transferring the appropriate technology associated with them

3. Introducing high-efficiency air conditioning equipment into China to replace existing low-efficiency equipment

4. Introducing high-efficiency illuminating technologies into the Chinese market.

Under the seventh five-year plan (1986 to 1990), the government continued those policies that had made remarkable strides in the past 10 years. Twenty institutes are devoted to renewable energy research. China's national efforts have been complemented by international exchanges. As of 1989, China had completed 23 cooperative projects with the European Economic Community (EEC), Italy, Belgium, Germany, England, Denmark, Japan, the Netherlands, and the United States.

Renewable energy has reached the stage of commercialization in China. More than 100 factories are devoted to manufacturing solar heaters, photovoltaic cells, and wind generators. China manufactures 100,000 solar cookers per year and 30,000 wind generators. China also has photovoltaic manufacturing capacity of $7 \mathrm{MW}_{\mathrm{p}}$ (peak watts), but currently only produces $0.5 \mathrm{MW}_{\mathrm{p}}$ per year. 


\section{Bibliography}

APEC Energy Team Schedule; April 1992

China World Trade; U.S. Dept. of Commerce; March 1992

Energy Conservation Programs in the People's Republic of China, Mark D. Levine and Liu Xeuyi

Energy in China; Ministry of Energy, People's Republic of China; 1990

Foreign Economic Trends and Their Implications for the United States; The American Embassy Beijing; May 1991

The Development of New and Renewable Sources of Energy in China; Chinese Solar Energy Society; 1991

The Illustrated Book of China's Large Hydropower Construction Management Organizations and Their Contracted Projects; The Department of Hydroelectric Power Development; 1991

Yu Lixing, Deputy Division Chief, Department of International Cooperation, Ministry of Energy, People's Republic of China - correspondence 


\begin{tabular}{l:c|}
\hline Title: Recovery of Waste Heat and Gases & Project Type: Study/demonstration \\
\hdashline Organization: State Planning Commission & Date: Sixth Five Year Plan, 1981 to 1985 \\
\hdashline End-use Sector: Industry & Affiliated/Future Projects: Unknown \\
Description: Two hundred million yuan was & Technology: Various improvements and new \\
invested in recovering coal gas from blast \\
furnaces, rotating furnaces, and coke ovens. In \\
the case of the Beitai Steel project, an \\
investment of 3.24 million yuan permitted the \\
recovery of the equivalent of 20,000 tons of \\
coal equivalent per year.
\end{tabular}

\begin{tabular}{|c|c|}
\hline Title: Recovery of Waste Heat and Gases & Project Type: Study/demonstration \\
\hline Organization: State Planning Commission & Date: Sixth Five Year Plan, 1981 to 1985 \\
\hline End-use Sector: Industry & Affiliated/Future Projects: Unknown \\
\hline $\begin{array}{l}\text { Description: In the chemical industry, } \\
\text { especially in sulfuric acid plants, heat and gases } \\
\text { were recovered to generate } 0.25 \text { billion } \mathrm{kWh} \text { of } \\
\text { electricity. In the paper and sugar industries, } \\
250 \mathrm{MW} \text { of generating capacity was installed. }\end{array}$ & Technology: Cogeneration and heat recovery \\
\hline Results: Unknown & Reference: Levine \& Liu \\
\hline
\end{tabular}




\begin{tabular}{|c|c|}
\hline $\begin{array}{l}\text { Title: Renovation of Industrial Boilers and } \\
\text { Furnaces }\end{array}$ & Project Type: Study/demonstration \\
\hline Organization: State Planning Commission & Date: Sixth Five Year Plan, 1981 to 1985 \\
\hline End-use Sector: Industry & $\begin{array}{l}\text { Affiliated/Future Projects: Unknown; it is } \\
\text { estimated that there are } 110,000 \text { industrial } \\
\text { furnaces in China. }\end{array}$ \\
\hline $\begin{array}{l}\text { Description: More than } 12,000 \text { boilers were } \\
\text { renovated during the period. Some units were } \\
\text { fitted with cogeneration equipment; in some } \\
\text { installations, several small boilers were replaced } \\
\text { with larger more efficient equipment, and others } \\
\text { were cleaned and tuned. }\end{array}$ & $\begin{array}{l}\text { Technology: Cleaning, tuning, and replacing } \\
\text { boilers and furnaces }\end{array}$ \\
\hline $\begin{array}{l}\text { Results: Average efficiency gain was } 10 \% \text { to } \\
15 \% \text {. }\end{array}$ & Reference: Levine \& Liu \\
\hline
\end{tabular}

\begin{tabular}{|c|c|}
\hline Title: Other Technology Modernization & Project Type: Study/demonstration \\
\hline Organization: State Planning Commission & Date: Sixth Five Year Plan, 1981 to 1985 \\
\hline End-use Sector: Industry & Affiliated/Future Projects: Unknown \\
\hline $\begin{array}{l}\text { Description: Altogether } 250 \text { yuan was devoted } \\
\text { to the purchase of more efficient specialized } \\
\text { equipment for a wide variety of industries } \\
\text { during the plan period. }\end{array}$ & Technology: Improved equipment \\
\hline $\begin{array}{l}\text { Results: Average project saved coal at an } \\
\text { equivalent price of } 340 \text { yuan per ton. }\end{array}$ & Reference: Levine \& Liu \\
\hline
\end{tabular}

\begin{tabular}{l|l|}
\hline Title: Recovery of coal wastes & Project Type: Study/demonstration \\
\hdashline Organization: State Planning Commission & Date: Sixth Five Year Plan, 1981 to 1985 \\
\hline End-use Sector: Industry & Affiliated/Future Projects: Unknown \\
\hdashline $\begin{array}{l}\text { Description: Wastes were used to produce both } \\
\text { electricity and heat and were used in the } \\
\text { manufacture of bricks and cement. }\end{array}$ & Technology: Various \\
\hdashline Results: Saved energy at the equivalent cost of & Reference: Levine \& Liu \\
140 yuan per ton of coal; an additional benefit \\
was the cleanup of the coal waste piles.
\end{tabular}




\begin{tabular}{|c|c|}
\hline Title: Improved Fertilizer Plant Efficiency & Project Type: Study/demonstration \\
\hline Organization: State Planning Commission & Date: Sixth Five Year Plan, 1981 to 1985 \\
\hline End-use Sector: Industry & Affiliated/Future Projects: Unknown \\
\hline $\begin{array}{l}\text { Description: Much of the nitrogenous fertilizer } \\
\text { produced in China comes from small, inefficient } \\
\text { plants. In } 1985 \text { the industry consumed } \\
\text { approximately } 5 \% \text { of the total energy consumed } \\
\text { in China. An investment of } 542 \text { million yuan } \\
\text { resulted in about a one-third reduction in coal } \\
\text { use at small fertilizer plants. }\end{array}$ & Technology: Unreported \\
\hline $\begin{array}{l}\text { Results: A } 22 \% \text { reduction in coal use at an } \\
\text { estimiated } 475 \text { yuan per ton of coal per year. } \\
\text { (Does not include productivity gains.) }\end{array}$ & Reference: Levine \& Liu \\
\hline
\end{tabular}

\begin{tabular}{l:l|}
\hline Title: Development of Solar Cookers & Project Type: Study/demonstration \\
\hdashline Organization: State Science and Technology & Date: Ongoing \\
Commission, State Planning Commission, and \\
Ministry of Agriculture, Department of Rural \\
Energy
\end{tabular}




\begin{tabular}{|l|l|}
\hline Title: Solar Projects in Tibet & Project Type: Study/demonstration \\
\hdashline Organization: Chinese Solar Energy Society & Date: Ongoing \\
\hdashline End-use Sector: Industry & $\begin{array}{l}\text { Affiliated/Future Projects: } 1990 \text { to } 2000 \text { Tibet } \\
\text { Sunshine Project plans to produce solar-powered } \\
\text { goods. }\end{array}$ \\
\hdashline $\begin{array}{l}\text { Description: Development of solar energy } \\
\text { projects }\end{array}$ & Technology: PV and passive solar \\
\hdashline $\begin{array}{l}\text { Results: Solar greenhouses multiplied } \\
\text { vegetable output. Solar baths were built. Over } \\
\text { 10,000 solar cookers were developed; PV power } \\
\text { generation was installed. }\end{array}$ & \\
\hline
\end{tabular}

\begin{tabular}{|c|c|}
\hline Title: Photovoltaic Development & Project Type: Study/demonstration \\
\hline $\begin{array}{l}\text { Organization: PV Division of Solar Energy } \\
\text { Society }\end{array}$ & Date: Ongoing \\
\hline $\begin{array}{l}\text { End-use Sector: Utility, industry, and } \\
\text { residential }\end{array}$ & $\begin{array}{l}\text { Affiliated/Future Projects: The government is } \\
\text { engaged in PV demonstrations for commercial } \\
\text { uses such as railway beacons and in } \\
\text { communications, and the military. It has } \\
\text { invested US } \$ 8 \text { million since } 1975 \text {. }\end{array}$ \\
\hline $\begin{array}{l}\text { Description: There are } 40 \text { research institutions } \\
\text { and factories engaged in PV R\&D. Seven } \\
\text { factories have a manufacturing capacity of } 7 \\
\text { MW production per year. Four PV power } \\
\text { stations with a capacity of } 5-10 \mathrm{~kW} \text { have been } \\
\text { built. }\end{array}$ & $\begin{array}{l}\text { Technology: The kinds of cells China has been } \\
\text { producing include PESC c-Si, c-Si, BSFR c-Si, } \\
\text { polycrystalline c-Si, GaAlAs/GaAs, CuS/Cd, a- } \\
\text { Si. }\end{array}$ \\
\hline $\begin{array}{l}\text { Results: Costs of production were reduced to } \\
\text { US } \$ 4.8 \text { per picowatt }(\mathrm{pW} \text { ) for amorphous and } \\
\text { US } \$ 8.65 / \mathrm{pW} \text { for c-Si cells. Efficiencies of } 18 \% \\
\text { were achieved in research and } 11 \% \text { in } \\
\text { production. }\end{array}$ & Reference: Chinese Solar Energy Society \\
\hline
\end{tabular}


Title: Biomass Development: Fuelwood and Efficient Stoves

Organization: Chinese government, Chinese Biomass Development Center, Ministry of Forest, Chinese Center for Rural Energy Research and Training (CCRERT).

End-use Sector: Residential, commercial building, industry

Description: In China, $70 \%$ of rural energy used is generated from biomass. The government has passed a number of laws aimed at conserving forests, planting, and maximizing volumetric yield. The government has also developed 20-30\% efficient stoves which reduce consumption of firewood by $30-50 \%$.

Results: 5.7 million hectares of fuelwood forests were planted of which $40 \%$ were rapidgrowing high-yield plantations. As of 1989, 114 million rural households $(57 \%)$ were using efficient stoves. CCRERT set standards for manufacturers of stoves.
Project Type: Policy assessment

Date: 1986; continuing

Affiliated/Future Projects: Continued distribution of stoves

Technology: Biomass, efficient stoves, alcohol production
Reference: RERIC news and Chinese Solar Energy Society
Title: Biomass Gasification

Organization: Chinese government and Chinese Academy of Agricultural Mechanization Science

End-use Sector: Commercial building; industry

Description: Gasifiers fueled by rural waste were developed that have outputs ranging from 200,000 kilojoules per hour ( $\mathrm{kJ} / \mathrm{hr}$ ) to 800,000 $\mathrm{kJ} / \mathrm{h}$.

Results: A $650,000 \mathrm{~kJ} / \mathrm{h}$ downdraft gasifier using wood chips was developed and is used in a furniture factory.
Project Type: Study/demonstration

Date: Ongoing

Affiliated/Future Projects: None

Technology: Draft-up and downdraft biomass gasification systems

Reference: Chinese Solar Energy Society 


\begin{tabular}{|c|c|}
\hline Title: Geothermal Utilization in China & Project Type: Study/demonstration \\
\hline $\begin{array}{l}\text { Organization: Ministry of Geology and } \\
\text { Mineral Resources }\end{array}$ & Date: Continuing \\
\hline $\begin{array}{l}\text { End-use Sector: Commercial, residential } \\
\text { building, electrification }\end{array}$ & $\begin{array}{l}\text { Affiliated/Future Projects: Geothermal } \\
\text { Utilization in Tibet }\end{array}$ \\
\hline $\begin{array}{l}\text { Description: More than } 3,000 \text { fields of hydro- } \\
\text { thermal potential were studied by the Chinese } \\
\text { government. The resource is used in industry, } \\
\text { agriculture, aquaculture, space heating, and } \\
\text { public baths. }\end{array}$ & $\begin{array}{l}\text { Technology: Geothermal electricity generation. } \\
\text { Most plants use water below } 100^{\circ} \mathrm{C} \text {, except for } \\
\text { Yangbajing }\left(165^{\circ} \mathrm{C}\right) \text { and Alee }\left(110^{\circ} \mathrm{C}\right) \text {. }\end{array}$ \\
\hline $\begin{array}{l}\text { Results: Forty-five geothermal fields have been } \\
\text { exploited which generate } 20.8 \mathrm{MW} \text { of electric } \\
\text { power and provide } 89.6 \text { tons of water for direct } \\
\text { heat, approximately } 41,222 \text { terajoules per year. } \\
\text { Yangbajing Geothermal Plant generates } 19.18 \\
\text { MW of electricity. Most sites directly use the } \\
\text { geothermal resource, which yields approximately } \\
17.5 \% \text { efficiency. }\end{array}$ & Reference: Chinese Solar Energy Society \\
\hline Title: Geothermal Utilization in Tibet & Project Type: Study/demonstration \\
\hline $\begin{array}{l}\text { Organization: Geothermal Development } \\
\text { Corporation of Tibet }\end{array}$ & Date: Early 1980 s - continuing \\
\hline $\begin{array}{l}\text { End-use Sector: Commercial, residential } \\
\text { buildings }\end{array}$ & $\begin{array}{l}\text { Affiliated/Future Projects: Geothermal } \\
\text { utilization in China }\end{array}$ \\
\hline $\begin{array}{l}\text { Description: There are } 1.2 \text { million } \mathrm{km}^{2} \text { in } \\
\text { Tibet containing geothermal resources. In the } \\
\text { mid-seventies, these resources were explored. }\end{array}$ & $\begin{array}{l}\text { Technology: The exploration strategy is } \\
\text { focused on searching for deep reservoirs for } \\
\text { fluid that could be used for geothermal plants. }\end{array}$ \\
\hline $\begin{array}{l}\text { Results: Six hundred geothermal areas were } \\
\text { found. }\end{array}$ & Reference: Chinese Solar Energy Society \\
\hline
\end{tabular}




\section{Philippines}

The Philippines occupies more than 7,000 islands inhabited by about 62 million people. These islands traverse more than $1,600 \mathrm{~km}$ from north to south along the southeastern rim of Asia. Only 154 of these islands exceed a land area of more than $13 \mathrm{~km}^{2}$, and $95 \%$ of the population resides on 11 of the islands. The Philippines is a member of the Association of Southeast Asian Nations (ASEAN).

The government operates through a constitutional presidential/congressional system. The president operates through a cabinet system, which carries out executive orders and the laws of Congress.

The Philippines has had an average gross domestic product (GDP) growth rate of $2.2 \%$ over the past 10 years. This growth also has been very cyclical; zero or negative growth occurred during 1983 to 1986 and nearly 5\% growth occurred from 1987 to 1990.

The Philippines GDP reached US $\$ 43,860$ million in 1990 , up from US $\$ 6,010$ million in 1965 . The GDP came from the following market sectors: agriculture (22\%), industry (35\%), and services (43\%); within industry, manufacturing comprised $25 \%$ of GDP. The GDP rose $3.1 \%$ in 1990 . A GDP growth of $1.9 \%$ was predicted for 1991 .

The average rate of inflation was $14.9 \%$ from 1980 to 1990 .

In 1990, exports totaled US\$8,681 million and imports totaled US $\$ 13,080$ million. During 1980 to 1990, this represents an average annual growth rate for exports of $2.5 \%$ and an average annual growth rate for imports of $2.3 \%$. The United States is the largest trading partner of the Philippines (35\% exports/25\% imports) followed by Japan (18\% exports/17\% imports) and the European Economic Community (EEC) (19\% exports $11 \%$ imports).

The Philippine government has passed extensive investment regulations and trade legislation. These regulations limit foreign direct investment in utilities, public works, and lands in the public domain. Trade regulations include tariffs between $5 \%$ and $80 \%$ on imported goods. Registered exporters receive tax credits and tariff reductions.

The Pacific Economic Outlook predicts that the cyclical nature of the economy in the Philippines will continue in the near future. The political elections scheduled for 1992 should provide a short-run stimulation for the economy. Some improvement in the trade balance is expected, and the deficit should decline. Privatization of government enterprises may occur at an accelerated rate, but interest rates will continue to be above $25 \%$. Inflation is projected at $8.3 \%$.

\section{Energy Use and Policy Issues}

In 1990, the Philippines' total energy consumption was 120.1 million barrels of oil equivalent (Mboe). By 2000 , the energy output should grow to $217 \mathrm{Mboe}$, and the government hopes the country will rely less on imported oil. In 1990, the imported oil cost the Philippines US $\$ 1,930$ million, representing $16 \%$ of total imports.

The Philippines use both imported and domestic sources of energy. Imported energy supplied $65.3 \%$ of the total energy, and domestic sources supplied $34.7 \%$. Imports consisted of oil (63.4\%) and coal $(1.91 \%)$. Domestic sources included agri-waste $(8.7 \%)$, hydro $(8.41 \%)$, geothermal $(7.5 \%)$, bagasse (4.51\%), domestic coal (3.8\%), and domestic oil (1.2\%). 
In 1985, the share of imported oil in the energy mix reached a new low (51\%) for the 1973 to 1990 period because of a confluence of positive and negative factors that include the increased availability and use of alternative energy sources, energy conservation that was induced by both price and government intervention, and the general slowdown in the economy. In 1990, dependence on imported oil rose to $64 \%$ because of a prolonged drought that limited hydro capacity, the unavailability of indigenous power supply from coal or geothermal to compensate for hydropower capacity loss, and a government decision to mothball a 620-megawatt (MW) nuclear plant. No alternative was available but to install diesel-powered generators.

Per capita energy consumption equaled 215 kilograms of oil equivalent (kgoe) in 1990, up from 158 kgoe in 1965 . For the period of 1980 to 1990 , energy consumption grew at an annual rate of 2.3\%. For the period between 1965 and 1980, energy consumption grew at an annual rate of 5.8\%.

The industrial sector consumes $50 \%$ of the energy, followed by residential/commercial $(27 \%)$ and transportation (18\%).

Electricity grew from $8.5 \%$ of final energy consumption in 1973 to $16 \%$ in 1990 . The latest electricity forecast is for an annual average growth of $7.7 \%$ from 1991 to 2000 , while energy demand for the same period is estimated to be $6.9 \%$ per year. Perhaps a more significant indicator of rapid energy growth is the annual growth rate of commercial energy demand-6.7\% over the period 1986 to 1990 as compared to $1.2 \%$ during the period 1976 to 1985 .

Three major grids supply approximately $5,600 \mathrm{MW}$. Electricity consumption accounts for $36 \%$ of total energy demand. The electricity demand is expected to increase at an average annual growth rate of $5.4 \%$ from 1988 to 2000 .

The Philippines is the world's second largest geothermal energy producer, having a total capacity of $894 \mathrm{MW}$. Although very little is known about the resource, there is a proven capacity of 1,614 MW and potential reserves of $6,818 \mathrm{MW}$. Philippine Geothermal Inc., a private company, produces $80 \%$ of the geothermal steam. The Philippine National Oil Company (PNOC)-Energy Development Corporation produces the other $20 \%$. At the present time, geothermal energy seems to be the most cost-effective method of increasing capacity.

\section{Energy Efficiency and Conservation}

Barriers to energy conservation include

- Insufficient information in the domestic sector

- Insufficient capital-investment in better production favored over investment in energy savings

- Inadequate training-lack of trained bank personnel to evaluate energy conservation projects; lack of company employees trained in specialized equipment

- Uncoordinated and overlapping functions of new and existing institutions implementing energy conservation activities

- Excessive bureaucratic procedures. 
After the 1974 oil crisis, the Philippine government called on the industrial and commercial sector to become involved in a nationwide effort to conserve energy. The first step was the formation of the Energy Conservation Movement of the Philippines (ENERCON), which encouraged research, testing, development and the adoption of energy-saving equipment and materials and alternative energy sources.

The government developed initiatives aimed at energy conservation in the transportation sector. These included studies on driving habits, maintenance, and road conditions. ENERCON also has regional and district energy chairmen who promote and monitor energy efficiency in the transportation sector.

The Energy Management Association of the Philippines (EMAP) also studies and promotes energy conservation. One report studied energy efficiency in the steel industry and made recommendations to improve efficiency using burners, preheating, and computer controls. EMAP also proposed tighter cooperation with the ASEAN Iron and Steel Industry Federation and the establishment of an ASEAN Energy Conservation Agency.

In 1980, an omnibus energy law (Batas Pambansa Blg. 73) was passed that requires energy conservation programs for high energy consumption industrial establishments. In 1991, Executive Order No. 418 was issued to monitor consumption of government and private establishments and reduce consumption of electricity and fuel. In the same year, House Bill No. 31312 was proposed to institutionalize energy conservation and define the government role. In addition, a bill proposing the creation of a Department of Energy that would facilitate implementation and coordination of policies and programs for the entire energy sector was certified by President Aquino for urgent enactment.

Today, the National Electrification Administration (NEA) encourages energy conservation by providing technical assistance programs and incentives. As a general policy, the Office of Energy Affairs (OEA) centers its energy conservation activities on the most energy-intensive industries. There are government assistance programs to aid with auditing, monitoring, and purchasing conservation equipment.

More specifically, for the buildings sector, there is a Room Air Conditioner Energy Certification Program. Under this program, products that comply with the minimum requirements for ratings on cooling capacity, amperage, and wattage bear the Philippine Standard certification mark. Air conditioners are being tested at the Fuels and Appliance Testing Laboratory of OEA. Additionally, building energy use standards were developed. Upon approval by the Department of Public Works and Highways, the standards will be incorporated in the National Building Code as referral code.

In the transportation sector, the focus is on metro Manila, where a significant portion of the fuel is consumed. A number of measures are being taken into consideration in order to minimize fuel consumption in transportation, including improving road system performance by enforcing traffic management measures and necessary control devices and road signs; increasing capacity and productivity of public transport; encouraging ridesharing or carpooling; instituting flexitime and staggered work and school hours; adopting transport pricing policies; and encouraging the use of bicycles. In the long term, transportation research will center on the research and development of alternative fuels such as alcogas, coco-diesel, automotive liquified petroleum gas, and other possible combinations of petroleum-based and nonpetroleum-based fuels.

OEA, in existence since 1987, generally sets energy policy in the Philippines. The Medium Term Energy Plan (1990 to 1992) has three fundamental objectives: 
1. Supply-to ensure the availability of energy to the markets in the country at reasonable prices

2. Demand-to promote the judicious and efficient use of energy resources

3. Environment- to accomplish both of the above objectives with minimal adverse effects on the environment.

The policies that will be followed in pursuit of these objectives include (1) the promotion of energy self-reliance, (2) endeavoring to provide the poorest sectors of the economy with energy at an affordable price, (3) encouragement of conservation measures to promote efficiency, (4) participation of the private sector in energy projects, and (5) maintenance of environmental and safety measures for energy projects.

In support of these policies, the strategies to be pursued include such actions as continuing indigenous energy-resource exploration and development, completing committed projects, departing from oil-based generation, reviewing sector efficiency in all stages, continuing viable energy conservation programs and projects, upgrading oil refinery capacity, restructuring power rates, recognizing marginal costs, pricing domestic petroleum products consonant with international prices, streamlining operations of electric cooperatives and utilities, maintaining the evaluation and implementation procedures on environmental aspects, and reducing public investments by inviting private capital to participate.

Other entities active in the energy industry include the NEA, the Bureau of Energy Development, the Bureau of Energy Utilization, and PNOC. Rural electrification cooperatives also exist.

Executive Order No. 215 established new regulations regarding private power. The National Power Corporation must now draft plans to buy private power. The OEA will enforce Executive Order No. 215.

The OEA promotes both renewable energy and conservation as part of the national energy policy. There also is a small industry involved with photovoltaics, solar water heaters, biomass-fired generation systems, biogas systems, mini-hydro, energy-efficient lamps, and energy consulting services.

In 1985, "nonconventional energy sources" accounted for $18 \%$ of all energy consumed in the Philippines. Almost $98 \%$ of this was biomass. A law was proposed to strengthen the nonconventional energy development program and will provide PH\$3.3 billion to develop "indigenous energy" sources over a five-year period. It also would give incentives to local manufacturers, dealers, and users of nonconventional energy equipment, which would include exemptions from tariffs, custom duties, and the value-added taxes.

The Philippines possesses a significant biomass waste resource from the production of sugar, coconuts, rice, and bananas. The Ministry of Agriculture estimates that there are 36 million metric tons of biomass resource.

The sugar processing industry of the Philippines seems extremely promising for biomass applications. At least 40 factories process cane and produce waste, having 81 megajoules (MJ) of energy potential. The National Food Authority has used rice hulls in their processing plants and Prince of Songkhla University has built wood-waste power plants. Private industry also has installed biogas and anaerobic digestion power systems. 
Comprising more than 7,000 islands, the Philippines represents a large potential market for rural electrification. The NEA administers a large rural electrification program, which will continue to expand. Most of the systems are operated by rural cooperatives, and there is a large potential for photovoltaics.

\section{The Oil Industry}

The Philippines possesses very few petroleum resources, but has been exploring for offshore oil. There are also three major refineries possessing a capacity of more than 280 thousand barrels per day.

PNOC was formed in response to the oil crisis of 1973. Its first responsibility was to transport, refine, and market crude. Today PNOC owns the largest refinery, transports $75 \%$ of the inter-island oil product, and holds nearly $40 \%$ of the domestic petroleum market. PNOC has expanded into non-oil energy sources and is composed of a number of subsidiaries:

- PNOC Coal Corporation-explores, mines, trades, and processes coal

- PNOC Energy Development Corporation-develops geothermal and non-oil resources

- PNOC Exploration Corporation-focuses on on-shore oil exploration in Central Laesione, Cebu, and Mindoro

- Malangas Coal Corporation-mines and processes coal

- Bislig Coal Corporation-explores, mines, and processes coal

- Transport and Logistics Group-eight corporations involved in the transport of crude and the maintenance of vessels

- Petroleum Refining/Marketing Group—many corporations that market and refine oil products.

Caltex and Shell Philippinas also refine crude oil in the Philippines.

\section{Bibliography}

Country Paper: Philippine Policies, Programs, and Approaches to Promote Energy Conservation; March 1991

Draft Business Plan for Photovoltaics Manufacturing and Distribution Company in the Philippines; Energy Conversion Devices Inc.

\section{Draft Market Study for Energy Conservation Technology}

Finesse Workshop, Financing of Energy Services for Small-Scale Energy Users, Country Market Study-Philippines; Conrado S. Heruela, Ma Eloida C. Balamiento, Marites I. Cabrera, Christopher G. Zamora, Socrates-Apollo P. Botictic, Reuben Emmanuel T. Quejas, Reynaldo V. Liganor, 
Angelito I. David, Charisse B. Tablante, Jesus Anunciacion, Asian and Pacific Development Centre; October, 1991

Philippines: Asia Pacific Energy Series: Country Report; Sharon Hoffman, Energy Program Resource Systems Institute; November 1988

Renewable Energy Market Survey: The Philippines; U.S. Export Council for Renewable Energy; February 1987

Transportation Energy Conservation Activities in the Philippines; A.A. Gimenez, Office of Energy Affairs, Bureau of Energy Utilization, Philippines; December 1987 


\begin{tabular}{l|l}
\hline Title: Energy Management Video Service & Project Type: Education/information \\
Organization: Office of Energy Affairs, \\
Philippines-German Rational Use of Energy \\
Project
\end{tabular}

\begin{tabular}{l:c|}
\hline $\begin{array}{l}\text { Title: Energy Management Advisory Service } \\
\text { (EMAS) }\end{array}$ & $\begin{array}{l}\text { Project Type: Education/info; policy } \\
\text { assessment }\end{array}$ \\
\hdashline $\begin{array}{l}\text { Organization: Office of Energy Affairs, } \\
\text { Philippines-German Rational Use of Energy } \\
\text { Project }\end{array}$ & Date: Ongoing \\
\hdashline End-use Sector: Industry & Affiliated/Future Projects: The Energy Bus \\
\hdashline $\begin{array}{l}\text { Description: The service helps industries } \\
\text { analyze their patterns of energy use. }\end{array}$ & $\begin{array}{l}\text { Technology: Conservation; energy monitoring } \\
\text { instruments, library, computer-data analysis }\end{array}$ \\
\hdashline $\begin{array}{l}\text { Results: EMAS conducted a boiler efficiency } \\
\text { program and published information on fans and } \\
\text { blowers. }\end{array}$ & \\
\hline
\end{tabular}


Title: The Philippine Steel Industry on the Upturn-Energy Conservation Essential to Remain Competitive

Organization: Energy Management Association of the Philippines

End-use Sector: Industry

Description: Energy profile of the steel industry in the Philippines; contains recommendations for conservation.

Results: The steel industry should make conservation a priority. Waste heat utilization, use of alternative/cheaper energy, improvement of operating efficiency, effective combustion control, use of process computers, better refractory materials, and continuous linkage of processes are all applicable measures. Estimate of annual energy savings using these measures is 23.58 million liters of oil.
Project Type: Study/demonstration

Date: 1987

Affiliated/Future Projects: None

Technology: Various

Reference: Estefanio M. Gacad, ASEAN-EC Energy Conservation Seminar, December 1987

\begin{tabular}{|c|c|}
\hline Title: Energy Conservation Awards & $\begin{array}{l}\text { Project Type: Policy assessment; } \\
\text { education/info }\end{array}$ \\
\hline Organization: Philippine government & Date: Ongoing \\
\hline End-use Sector: Industry & Affiliated/Future Projects: \\
\hline $\begin{array}{l}\text { Description: The Don Emilio Abello Awards } \\
\text { recognize companies demonstrating commitment } \\
\text { to energy conservation or using indigenous } \\
\text { energy in innovative ways. }\end{array}$ & Technology: Conservation \\
\hline Results: & $\begin{array}{l}\text { Reference: Philippine Policies, Programs, and } \\
\text { Approaches to Remote Energy Countries }\end{array}$ \\
\hline
\end{tabular}

\begin{tabular}{|c|c|}
\hline Title: Rice-Hull-Fired Power Plant & Project Type: Study/demonstration \\
\hline Organization: National Food Authority & Date: Built and tested between 1986 and 1988 \\
\hline End-use Sector: Industry & Affiliated/Future Projects: \\
\hline $\begin{array}{l}\text { Description: The National Food Authority uses } \\
3 \text { tons of rice hull per hour to generate } 2.1 \mathrm{MW} \text {. }\end{array}$ & $\begin{array}{l}\text { Technology: Biomass. There are at least } 600 \\
\text { biogas plants in the Philippines. }\end{array}$ \\
\hline Results: The plant is operating successfully. & Reference: RERIC News \\
\hline
\end{tabular}




\begin{tabular}{|c|c|}
\hline $\begin{array}{l}\text { Title: Transportation Energy Conservation } \\
\text { Activities }\end{array}$ & Project Type: R\&D \\
\hline $\begin{array}{l}\text { Organization: Department of Transportation } \\
\text { and Communications, ENERCON }\end{array}$ & Date: 1978 to 1980 \\
\hline End-use Sector: Transportation & $\begin{array}{l}\text { Affiliated/Future Projects: Energy } \\
\text { management seminars }\end{array}$ \\
\hline $\begin{array}{l}\text { Description: Research examined the effects of } \\
\text { maintenance, driving habits, road conditions, } \\
\text { and fuel consumption of cars. }\end{array}$ & Technology: Conservation \\
\hline $\begin{array}{l}\text { Results: Taxi companies and buses enacted } \\
\text { energy conservation programs. The government } \\
\text { also plans to develop alternative fuels and } \\
\text { increased capacity of public transport. }\end{array}$ & $\begin{array}{l}\text { Reference: ASEAN-EC Energy Conservation } \\
\text { Seminar, A. A. Gimenez, December } 1987\end{array}$ \\
\hline
\end{tabular}

Title: Room Air Conditioning Service Program

Organization: Philippine government

End-use Sector: Commercial, residential buildings

Description: The government tests airconditioners and sets standards for cooling capacity, usage, and voltage.

\section{Results:}

Project Type: Policy assessment; standards and codes; certification

Date: Ongoing

\section{Affiliated/Future Projects:}

Technology: Conservation

Reference: Philippine Policies, Programs, and Approaches to Remote Energy Countries
Title: Technology Transfer for Energy Management (TTEM)

Organization: Office of Energy Affairs

End-use Sector: Industry

Description: TTEM is a pioneer project to promote the adoption of energy-efficient technology.

Results: EMAP expects the 12 projects under way to save 56,008 barrels of oil. The projects include work in the telephone, carpet, glass, cement, and steel industries.

\section{Project Type: Study/demonstration}

Date: 1990; continuing

Affiliated/Future Projects: There was more than P\$40 million in funding. Some of the funds were provided through TTEM loans.

Technology: Conservation

Reference: EMAP Energy Manager 


\begin{tabular}{|l|l|}
\hline Title: Building Energy Standards & Project Type: Standards and codes \\
\hdashline Organization: Office of Energy Affairs & Date: Ongoing \\
\hdashline End-use Sector: Commercial building & Affiliated/Future Projects: \\
\hdashline Description: The government developed & Technology: Conservation \\
energy standards for commercial buildings. & \\
\hdashline Results: & Reference: Philippine Policies, Programs, and \\
\hline
\end{tabular}

\begin{tabular}{|c|c|}
\hline Title: The Energy Bus for Energy Audits & Project Type: Study/demo; policy assessment \\
\hline $\begin{array}{l}\text { Organization: Philippines-German Rational } \\
\text { Use of Energy Project }\end{array}$ & Date: 1987 ; continuing \\
\hline End-use Sector: Commercial building; industry & Affiliated/Future Projects: \\
\hline $\begin{array}{l}\text { Description: A bus holding measuring } \\
\text { equipment to conduct energy use audits. }\end{array}$ & $\begin{array}{l}\text { Technology: The bus is equipped with a stack } \\
\text { gas analyzer, measuring equipment for motors, } \\
\text { temperature, pressure, and volume flow } \\
\text { measuring devices, and water testing equipment. }\end{array}$ \\
\hline $\begin{array}{l}\text { Results: The Energy Bus allows a small team } \\
\text { of engineers to analyze a company's energy use. } \\
\text { The Energy Bus cost } \$ 130,000 \text {. }\end{array}$ & Reference: The Making of an Energy Bus \\
\hline
\end{tabular}

\begin{tabular}{l:l|l}
\hline Title: Energy-Efficient Lighting & Project Type: Policy assessment \\
\hdashline Organization: EMAP, industry & Date: Ongoing \\
\hdashline End-use Sector: Industry & Affiliated/Future Projects: NEA \\
\hdashline Description: Three subsidiaries of foreign lamp & Technology: High-efficiency lamps \\
manufacturers dominate the lighting market. & \\
\hdashline Results: The market is undeveloped, but the & Reference: FINESSE Country Market Study, \\
NEA has promoted high-efficiency lighting. In & ENMAP Energy Manager \\
the FINESSE study, three market options were \\
discussed. The lamp market could be over \\
100,000 units a year. EMAP also has issued \\
guidelines for office lighting to improve the \\
lighting environment, reduce eye fatigue, and \\
maximize daylighting.
\end{tabular}


Title: Renewable Energy Association of the Philippines (REAP)

Organization: OEA, REAP

End-use Sector: All sectors

Description: The OEA helped organize REAP, an organization of manufacturers, importers, distributors, and energy service firms.

Results: REAP has promoted nonconventional energy sources and secured financial assistance from the OEA.
Project Type: Policy assessment; tech transfer

Date:

Affiliated/Future Projects:

Technology: Conservation and renewable energy

Reference: FINESSE
Title: Photovoltaics in the Philippines

Organization: Industry

End-use Sector: Industry

Description: There are at least five PV suppliers in the Philippines, but local manufacturing and expertise is lacking.

Results: The import duty was reduced from $40 \%$ to $3 \%$ and might go as low as $0 \%$. Industry estimates demand to be around $273 \mathrm{~kW}_{\mathrm{p}}$ if financing were available. Approximately $42,000 \mathrm{~kW}_{\mathrm{p}}$ were installed in the last 18 years.
Project Type: Policy assessment; study/demo

Date: Ongoing

Affiliated/Future Projects: SAPMASOPCO, a rural solar cooperative, financed 100 solar homes; USAID water pumping projects.

Technology: Photovoltaics

Reference: FINESSE Country Market Study
Title: Solar Electric Company, Inc. Projects

Organization: Solar Electric Company, Inc.

End-use Sector: Industry

Description: Solar Electric has been supplying photovoltaics (PV) to the Philippines since 1977. Current projects include PV power for a seven-building business park, a hotel, and a garbage dump site.

Results: Not available
Project Type: Study/demonstration

Date: Ongoing

Affiliated/Future Projects: Contact Solar Electric in Manila, Philippines

Technology: Photovoltaic systems

Reference: PV News 


\begin{tabular}{|c|c|}
\hline $\begin{array}{l}\text { Title: Philippine German Solar Energy Project; } \\
\text { Burias Island and Verde Island PV Projects }\end{array}$ & Project Type: Study/demomonstration \\
\hline Organization: OEA - GTZ & Date: 1988 \\
\hline End-use Sector: Renewable energy & $\begin{array}{l}\text { Affiliated/Future Projects: The demand for } \\
\text { solar home systems should reach } 200 \text { units a } \\
\text { year on Burias Island. }\end{array}$ \\
\hline $\begin{array}{l}\text { Description: The commercial development of } \\
\text { PV started with the GTZ-supported } 13.3 \mathrm{~kW}_{\mathrm{p}} \\
\text { central Pulong Sampalac installation. A rural } \\
\text { electrification project used } 50 \mathrm{~W}_{\mathrm{p}} \text { home } \\
\text { systems. }\end{array}$ & $\begin{array}{l}\text { Technology: A } 50-\mathrm{kW}_{\mathrm{p}} \text { photovoltaic solar } \\
\text { home system was developed. }\end{array}$ \\
\hline $\begin{array}{l}\text { Results: On Burias Island, PV systems have } \\
\text { been used for refrigeration, communications, } \\
\text { and home electrification. The project also } \\
\text { provided a model financing scheme. }\end{array}$ & Reference: FINESSE Country Market Study \\
\hline
\end{tabular}

\begin{tabular}{|c|c|}
\hline Title: Biogas Developments in the Philippines & Project Type: Study/demonstration \\
\hline Organization: Ministry of Energy & Date: 1985 \\
\hline End-use Sector: Renewable energy & $\begin{array}{l}\text { Affiliated/Future Projects: There are at least } \\
600 \text { biogas plants in the Philippines. }\end{array}$ \\
\hline $\begin{array}{l}\text { Description: Total biogas output in } 1985 \\
\text { totaled } 10,000 \mathrm{~m}^{3} \text { per day. At Maya-Farms, the } \\
\text { world's largest biogas system provides all of the } \\
\text { energy for a hog farm and meat packing } \\
\text { complex. }\end{array}$ & Technology: Biogas \\
\hline $\begin{array}{l}\text { Results: A distillery and an ice plant also use } \\
\text { biogas. }\end{array}$ & Reference: Bioenergy Systems Report \\
\hline
\end{tabular}




\begin{tabular}{|c|c|}
\hline Title: Rice Hull Gasifier & Project Type: R\&D; study/demo \\
\hline $\begin{array}{l}\text { Organization: Philippine Department of } \\
\text { Agriculture, UC Davis, and Intemational Rice } \\
\text { Research Institute }\end{array}$ & Date: \\
\hline End-use Sector: Industry & $\begin{array}{l}\text { Affiliated/Future Projects: Biogas. There are } \\
\text { at least } 600 \text { biogas plants in the Philippines. }\end{array}$ \\
\hline $\begin{array}{l}\text { Description: The program carried out design, } \\
\text { production, and performance testing of gasifiers. }\end{array}$ & Technology: Open core downdraft gasifier \\
\hline $\begin{array}{l}\text { Results: The program developed a small } \\
\text { gasifier for demonstration, commercial cooking, } \\
\text { and food processing. A larger gasifier }(0.77-\mathrm{m} \\
\text { inside diameter) also was tested. }\end{array}$ & Reference: RERIC News \\
\hline
\end{tabular}

\begin{tabular}{|c|c|}
\hline Title: Rice-Hull-Fired Onion Dryer & Project Type: Study/demonstration \\
\hline $\begin{array}{l}\text { Organization: Forest Products Research and } \\
\text { Development Institute }\end{array}$ & Date: 1987 to 1991 \\
\hline End-use Sector: Industry & $\begin{array}{l}\text { Affiliated/Future Projects: Twenty more units } \\
\text { are planned for installation. }\end{array}$ \\
\hline Description: & Technology: Biomass \\
\hline $\begin{array}{l}\text { Results: An experimental dryer was installed } \\
\text { on a farm. The capacity was } 126 \text { onion boxes. } \\
\text { The dryer can cure a load in } 48 \text { to } 60 \text { hours. }\end{array}$ & Reference: RERIC News \\
\hline
\end{tabular}




\begin{tabular}{|c|c|}
\hline Title: Geothermal Energy Incentives & Project Type: Policy assessment \\
\hline Organization: Office of Energy Affairs & Date: 1991 \\
\hline End-use Sector: Renewable energy & $\begin{array}{l}\text { Affiliated/Future Projects: Geothermal } \\
\text { Development by PROC and NAPOCOR }\end{array}$ \\
\hline $\begin{array}{l}\text { Description: Twenty percent of the energy in } \\
\text { the Philippines is supplied by geothermal, but } \\
\text { development is below expectations. Efforts are } \\
\text { under way to pass a law to give incentives to } \\
\text { the private sector to develop geothermal. }\end{array}$ & Technology: Geothermal \\
\hline $\begin{array}{l}\text { Results: Philippine geothermal output is } \\
\text { supposed to reach } 1,750 \mathrm{MW} \text { by } 1995 \text {. Current } \\
\text { output is } 850 \mathrm{MW} \text {. }\end{array}$ & Reference: RERIC News \\
\hline
\end{tabular}

\begin{tabular}{|c|c|}
\hline $\begin{array}{l}\text { Title: FINESSE (Financing Energy Services for } \\
\text { Small-Scale Energy Users) }\end{array}$ & Project Type: Policy assessment \\
\hline $\begin{array}{l}\text { Organization: The World Bank, U.S. } \\
\text { Department of Energy, USAID, U.S. } \\
\text { Environmental Protection Agency, UNDP, Asian } \\
\text { Development Bank, Asian and Pacific } \\
\text { Development Center, Netherlands Ministry of } \\
\text { Foreign Affairs }\end{array}$ & Date: FINESSE was launched in 1989. \\
\hline End-use Sector: All sectors & $\begin{array}{l}\text { Affiliated/Future Projects: Sukitani PV } \\
\text { Electrification }\end{array}$ \\
\hline $\begin{array}{l}\text { Description: Project FINESSE was launched to } \\
\text { conduct market studies, promote manufacture of } \\
\text { energy-efficient light bulbs and appliances, } \\
\text { examine the institutional environment for } \\
\text { alternative energy projects, establish ASEAN } \\
\text { project opportunities, establish a multidonor } \\
\text { feasibility fund, and host international } \\
\text { conferences. }\end{array}$ & Technology: All renewable energy \\
\hline $\begin{array}{l}\text { Results: FINESSE has completed market } \\
\text { studies on Malaysia, Philippines, Indonesia, and } \\
\text { Thailand. The studies identified project } \\
\text { opportunities for renewable energy. }\end{array}$ & $\begin{array}{l}\text { Reference: FINESSE Country Market Studies, } \\
\text { FINESSE Report }\end{array}$ \\
\hline
\end{tabular}




\begin{tabular}{|c|c|}
\hline jə[udured dWWNG :әวuәдәృə8 & 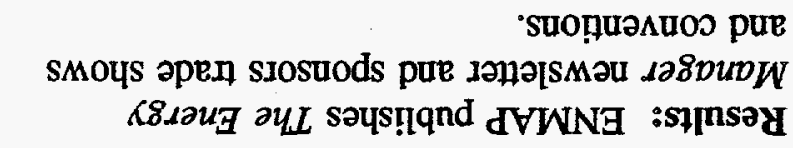 \\
\hline 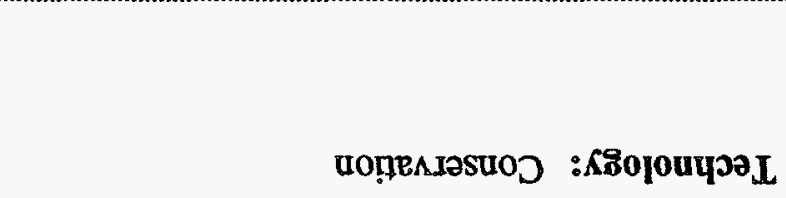 & 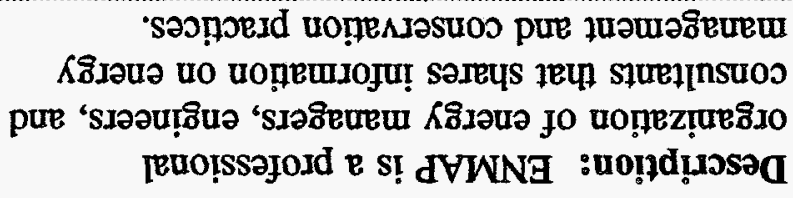 \\
\hline 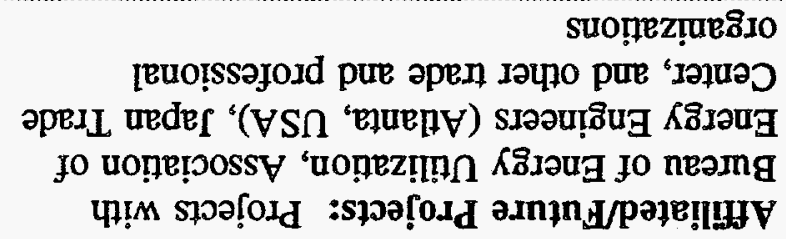 & sıOłวəS IIV :JopəəS әsn-pug \\
\hline 6L6I :ә78 & 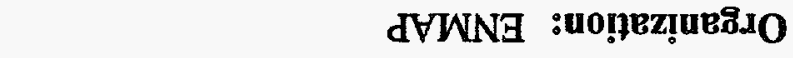 \\
\hline 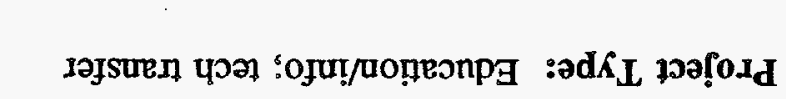 & 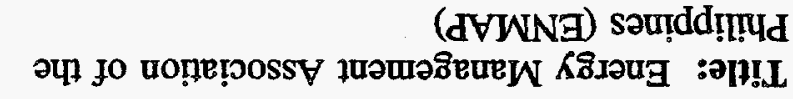 \\
\hline
\end{tabular}

\begin{tabular}{|c|c|}
\hline 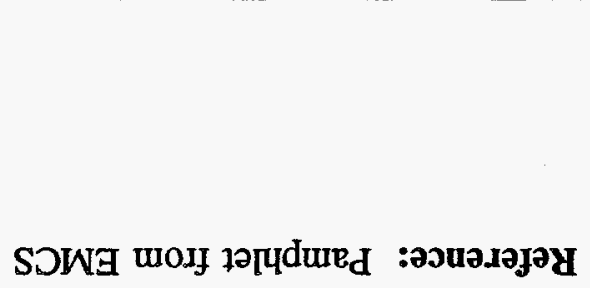 & 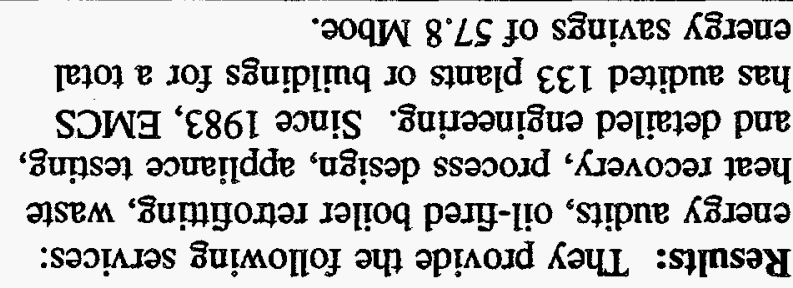 \\
\hline 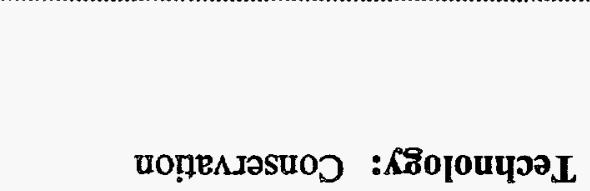 & 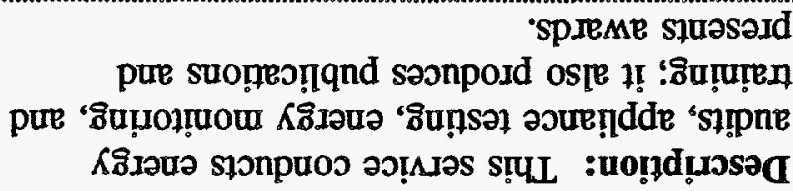 \\
\hline 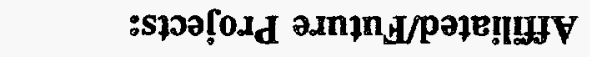 & 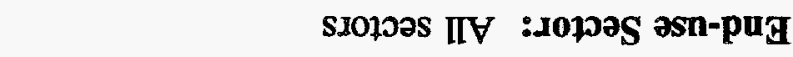 \\
\hline 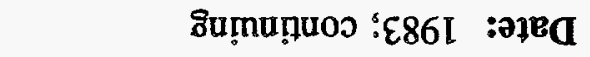 & 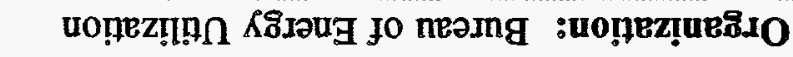 \\
\hline 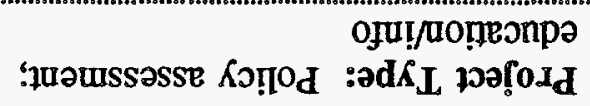 & 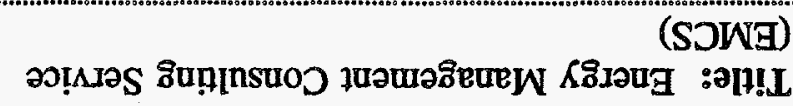 \\
\hline
\end{tabular}




\section{Singapore}

Singapore occupies an island with an area of $619 \mathrm{~km}^{2}$ off the southern coast of peninsular Malaysia. It is populated by 2.6 million people of mixed ethnic backgrounds from China, Malaysia, and India.

Singapore is a charter member of the Association of Southeast Asian Nations (ASEAN) group and a member of international organizations, including the Asian Development Bank and the United Nations.

Singapore experienced rapid economic growth in 1990 with a growth in gross national product (GNP) of $8.2 \%$. The demand for energy grew at $8.8 \%$ during this same period.

Singapore's strategic location, political stability, and industrious population give the country an important economic position in Southeast Asia. The annual growth rate of gross domestic product (GDP) during the seventies was close to $10 \%$. It dipped to $8.5 \%$ between 1980 and 1984 , but rebounded to $11 \%$ in 1988 .

Singapore's GDP reached US $\$ 34,600$ million in 1990 , up from US $\$ 970$ million in 1965 . This represents an average annual growth rate of $6.4 \%$ for the years 1980 to 1990 . The GDP came from the following market sectors: agriculture (0\%), industry (37\%), and services (63\%); within industry, manufacturing comprises $29 \%$ of GDP. The GDP rose $8.3 \%$ in 1990 . A GDP growth of $7.0 \%$ was predicted for 1991.

In 1990 , exports totaled US $\$ 52,627$ million and imports totaled US $\$ 60,647$ million. Over the period 1980 to 1990 , this represents an average annual growth rate for exports of $8.6 \%$ and an average annual growth rate for imports of $6.7 \%$.

In 1988, the United States was Singapore's largest trading partner. Major exports included rubber, electronics, and textiles. Imports from the United States included machinery and other manufactured products. Singapore imports most of its food except for a small portion of vegetables.

The United States also is the largest source of foreign investment in Singapore, representing nearly one-third of all private investment and one-quarter of total investment. U.S. activities include oil refining, shipping, banking, and hotels.

Singapore has emerged as a leading financial and business services center because banks can bridge the gap between the New York/London and Tokyo/Hong Kong markets. Over 100 branches of foreign banks and 50 merchant banks operate in Singapore. It is the world's main Asia-dollar market and a large foreign exchange center. Singapore also offers an around-the-clock link with the Chicago Mercantile Exchange.

Singapore has successfully diversified and opened its economy since 1985 . One example of this purposeful shift is the international economic cooperation in the "growth triangle" with Indonesia and Malaysia. Singapore also actively seeks investment from ASEAN members and Latin American countries.

\section{Energy Use and Policy Issues}

In 1988, Singapore's total energy consumption was 9.51 million tons of oil equivalent (Mtoe). By the year 2000 , this is expected to be 14.3 Mtoe. 
Besides its strategic location in the shipping lanes between Asia and the west, Singapore has no natural resources and relies completely on imported oil for domestic energy production.

Per capita energy consumption equaled 5,685 kilograms of oil equivalent (kgoe) in 1990, up from 2,214 kgoe in 1965. For the period of 1980 to 1990 , energy consumption grew at an annual rate of $5.8 \%$. For the years between 1965 and 1980, energy consumption grew at an annual rate of $5.7 \%$.

Fuel oil constitutes the largest component of Singapore's domestic product demand. For example, in 1986, fuel oil constituted more than $70 \%$ of total domestic energy consumption. Fuel oil was used for electricity generation, industry, and maritime transport. Residential users consumed $20 \%$ of the total domestic energy demand, using automobiles, cooking, and electricity.

The Public Utilities Board (PUB) runs four power stations having a total generating capacity of 3,627 megawatts (MW). The board plans on adding two additional gas turbines, which will bring the total capacity to $4,633 \mathrm{MW}$.

The PUB also produces and distributes piped town gas. As of 1986, there were approximately 190,000 customers in the following market sectors: residential (54\%), commercial (40\%), and industrial (10\%). The PUB had a capacity of 735,000 cubic meters per day and plans to double its number of customers by 1990 .

No official policy or energy forecast exists in Singapore, but several agencies shape the energy sector. The parastatal Singapore National Oil Company (SNOC) is supposed to ensure reasonable protection of the oil supply for continued growth in Singapore's economy. SNOC also maintains a cooperative relationship with the ASEAN Council on Petroleum and the Public Utilities Board.

\section{The Oil Industry}

The Singapore oil industry began in the colonial period when the island served as a storage, transshipment, and distribution center for the Far East. In 1961, Shell opened the first refinery having a capacity of 20,000 barrels per day. Today, Shell continues to operate in Singapore; other companies like Esso, Mobil, Caltex, and BP also have major refineries. The country's combined capacity is more than 1 million barrels per day. The petroleum industry's output in 1990 was US\$4.7 billion, $14.7 \%$ of Singapore's total manufacturing output.

\section{Energy Efficiency and Conservation}

Office and commercial buildings account for about $25 \%$ of the total electricity consumption. Therefore, insulating chilled water pipes, cold air ducts, and building walls and other such measures are important to improve the efficiency of energy use in Singapore. Problems arise with air conditioning from high ambient temperatures and high relative humidities and moisture during frequent heavy rains.

The PUB publishes pamphlets on energy and water conservation. Electricity and You describes energy production and Save Energy and Money illustrates easy ways to save energy around the home. The PUB also publishes average consumption levels and estimated energy-cost information for selected home appliances. 
A major energy-efficiency effort is the ASEAN-Australia Program, which was implemented in two phases.

Phase I (1982 to 1989) consisted of four program areas:

- Energy analysis and modeling of buildings-refined and improved a microcomputer program to analyze and model energy usage, including air conditioning systems. Program now in use by building control authorities. Singapore is the center for the software development network for ASEAN.

- Industrial energy management-compiled energy consumption data for several industries; found areas for improvement, particularly through heat recovery.

- Optimization of insulation materials-developed equipment to measure thermal properties of insulations; worked on standard testing and evaluation methods.

- $\quad$ Heat pumps testing - used heat pumps in buildings to produce domestic hot water by recovering heat from air conditioning systems. Researchers developed a better method of testing capacity rating of these water-to-water heat pumps.

Phase II (1990 to 1995) includes three program areas:

- Industrial energy management-develop local expertise in the design and manufacture of heat exchangers for drying applications in food processing and fish/prawn feed industries. Planned activities include developing prototypes, field demonstrations, and techno-economic analysis.

- Energy analysis and modeling of buildings (standards)-continue Phase I to complete Building Energy Performance Standards and Codes of Practice. Planned activities include more energy audits and further testing and development of microcomputer modeling software. Other ASEAN countries will participate in training and workshops.

- Energy analysis and modeling of buildings (air handlers)-test and modify, as necessary, a new type of air handler (currently marketed in Australia) to improve the efficiency of dehumidification in Singapore buildings.

University researchers have studied solar cooling, insulation, and conservation. Researches also have completed work on recycling sludge for construction material and using palm oil waste as fuel.

Renewable energy firms, including biomass and geothermal, from the United States and other nations are represented in Singapore, even though Singapore itself is not viewed as a substantial market for these technologies. 


\section{Bibliography}

Electricity \& You; Public Utilities Board

Energy Conservation \& Exhibition Centre; Public Relations Division

Public Utilities Board At Your Service; Public Utilities Board

Public Utilities Board Annual Report 1990

Republic of Singapore Government Gazette Subsidiary Legislation Supplement; Published by Authority; August 1979

Save Energy \& Money; Public Utilities Board

Singapore: Asia Pacific Energy Series: Country Report; Tilak Doshi, Energy Program Resource Systems Institute; June 1988

Singapore's Petroleum Industry: The Quiet Achiever; The Embassy of the United States of America, Singapore; July 1990

The Building Control Act 1989 and The Building Control Regulations 1989 


\begin{tabular}{|l|l|}
\hline Title: Mass Transportation System & Project Type: Study/demonstration \\
\hdashline Organization: Government of Singapore & Date: 1987; continuing \\
\hdashline End-use Sector: Transportation & Affiliated/Future Projects: \\
\hdashline $\begin{array}{l}\text { Description: There has been a preliminary } \\
\text { study to evaluate the impact of a mass } \\
\text { transportation system on energy usage. }\end{array}$ & Technology: Light rail \\
\hdashline $\begin{array}{l}\text { Results: Forty-six stations were planned to } \\
\text { open by 1990. }\end{array}$ & Reference: ASEAN-EC Conservation Seminar \\
\hline
\end{tabular}

\begin{tabular}{|c|c|}
\hline Title: Energy Conservation Using Heat Pumps & Project Type: R\&D \\
\hline $\begin{array}{l}\text { Organization: National University of } \\
\text { Singapore }\end{array}$ & Date: 1988 ; continuing \\
\hline End-use Sector: Commercial building & $\begin{array}{l}\text { Affiliated/Future Projects: The department of } \\
\text { mechanical engineering of the University of } \\
\text { Singapore has undergraduate and graduate } \\
\text { courses on energy and renewable energy. }\end{array}$ \\
\hline $\begin{array}{l}\text { Description: Researchers developed computer } \\
\text { programs for steady-state performance of heater } \\
\text { pumps. Their results are being verified against } \\
\text { actual experiments. }\end{array}$ & Technology: Heat pumps \\
\hline $\begin{array}{l}\text { Results: The next step of the project was to } \\
\text { determine heat pump operating conditions over } \\
\text { a range of operating conditions. }\end{array}$ & Reference: RERIC News \\
\hline
\end{tabular}




\begin{tabular}{|c|c|}
\hline $\begin{array}{l}\text { Title: ASEAN-Australia Economic Cooperative } \\
\text { Program (AAECP) }\end{array}$ & Project Type: R\&D; study/demo \\
\hline $\begin{array}{l}\text { Organization: PUB; Nanyang Technological } \\
\text { Institute, National University of Singapore; } \\
\text { AAECP. }\end{array}$ & Date: 1985 to 1988 \\
\hline End-use Sector: Commercial building & $\begin{array}{l}\text { Affiliated/Future Projects: The department of } \\
\text { mechanical engineering of the University of } \\
\text { Singapore has undergraduate and graduate } \\
\text { courses on energy and renewable energy. }\end{array}$ \\
\hline $\begin{array}{l}\text { Description: AAECP provided US } \$ 540,000 \text { for } \\
\text { the program. }\end{array}$ & Technology: Conservation \\
\hline $\begin{array}{l}\text { Results: The research included energy analysis } \\
\text { and modeling of buildings (Chou), industrial } \\
\text { energy management (Ho), optimization of } \\
\text { insulating materials (Wijeysundera), and heat } \\
\text { pumps (Bong). }\end{array}$ & Reference: RERIC News \\
\hline
\end{tabular}

\begin{tabular}{|c|c|}
\hline Title: The Building Control Code of 1989 & $\begin{array}{l}\text { Project Type: Policy assessment; standards } \\
\text { and codes }\end{array}$ \\
\hline Organization: Government of Singapore & Date: 1989 \\
\hline $\begin{array}{l}\text { End-use Sector: Commercial, residential } \\
\text { buildings }\end{array}$ & $\begin{array}{l}\text { Affiliated/Future Projects: The Handbook on } \\
\text { Energy Conservation in Buildings calls for } \\
\text { standards in the overall thermal transfer value. }\end{array}$ \\
\hline $\begin{array}{l}\text { Description: The government amended the } \\
\text { 'Building Control Act of } 1974 \text { to include energy } \\
\text { efficiency. }\end{array}$ & $\begin{array}{l}\text { Technology: Conservation, daylighting, and } \\
\text { ventilation }\end{array}$ \\
\hline $\begin{array}{l}\text { Results: The building codes call for natural } \\
\text { light, ventilation, and insulation. There will be } \\
\text { energy auditing and standards for thermal } \\
\text { transfer values. }\end{array}$ & $\begin{array}{l}\text { Reference: The Building Control Code of } \\
\text { 1989. APEC reply }\end{array}$ \\
\hline
\end{tabular}




\begin{tabular}{|c|c|}
\hline Title: Energy Technologies Research & Project Type: R\&D \\
\hline $\begin{array}{l}\text { Organization: National University of } \\
\text { Singapore. ASEAN-Australia Economic } \\
\text { Cooperation Program }\end{array}$ & Date: 1986 ; continuing \\
\hline End-use Sector: Industry; commercial building & Affiliated/Future Projects: \\
\hline $\begin{array}{l}\text { Description: Projects have researched energy } \\
\text { modeling of buildings, industrial energy } \\
\text { management, insulation materials, and heat } \\
\text { pumps. }\end{array}$ & $\begin{array}{l}\text { Technology: Renewable energy and } \\
\text { conservation }\end{array}$ \\
\hline Results: & $\begin{array}{l}\text { Reference: ASEAN-EC Energy Conservation } \\
\text { Seminar }\end{array}$ \\
\hline
\end{tabular}

\begin{tabular}{|c|c|}
\hline Title: Moisture Effects on Insulation & Project Type: R\&D \\
\hline $\begin{array}{l}\text { Organization: National University of } \\
\text { Singapore }\end{array}$ & Date: 1988 \\
\hline End-use Sector: Commercial building & $\begin{array}{l}\text { Affiliated/Future Projects: The department of } \\
\text { mechanical engineering of the University of } \\
\text { Singapore has undergraduate and graduate } \\
\text { courses on energy and renewable energy. }\end{array}$ \\
\hline $\begin{array}{l}\text { Description: The project measures vapor } \\
\text { diffusion and moisture condensation in pipe } \\
\text { insulation. It also tests heat transfer } \\
\text { characteristics of moist insulation. }\end{array}$ & Technology: Insulation \\
\hline $\begin{array}{l}\text { Results: Heat flux variation and moisture } \\
\text { condensation were measured and methods of } \\
\text { moisture removal were tested. }\end{array}$ & Reference: RERIC News \\
\hline
\end{tabular}




\begin{tabular}{|l:l|}
\hline $\begin{array}{l}\text { Title: Energy Conservation and Exhibition } \\
\text { Center }\end{array}$ & $\begin{array}{l}\text { Project Type: Policy assessment; } \\
\text { education/info }\end{array}$ \\
\hdashline Organization: Singapore Public Utilities Board & Date: 1987; continuing \\
\hdashline End-use Sector: All sectors & \begin{tabular}{l} 
Affiliated/Future Projects: \\
\hdashline $\begin{array}{l}\text { Description: The Public Utilities Board runs an } \\
\text { information center and provides education to the } \\
\text { public on energy and water conservation. }\end{array}$
\end{tabular} \\
\hdashline $\begin{array}{l}\text { Results: The center provides a museum-like } \\
\text { atmosphere with audio/visual displays, exhibits, } \\
\text { and quiz machines. The center produces } \\
\text { pamphlets and publications and established an } \\
\text { answering service. }\end{array}$ & Reference: Conservation \\
\hline
\end{tabular}




\section{Thailand}

Thailand is a charter member of the Association of Southeast Asian Nations (ASEAN) group; it covers some $515,000 \mathrm{~km}^{2}$ and has a population of approximately 57.6 million. About $65 \%$ of the population is involved with agricultural production. Thailand has been experiencing rapid economic growth, having a 1990 growth in gross national product (GNP) of $10.0 \%$. During this same year, energy consumption rose $8.9 \%$.

Thailand has been a top economic performer in the ASEAN region, having gross domestic product (GDP) grow at an average rate of approximately $7.5 \%$ over the past 20 years and achieving doubledigit growth from 1987 to 1990 . Thailand's GDP reached US $\$ 80,170$ million in 1990 , up from US\$4,390 million in 1965. The GDP came from the following market sectors: agriculture (12\%), industry (39\%), and service (48\%); within industry, manufacturing comprised $26 \%$. GDP rose $7.5 \%$ in 1991.

Traditionally, Thailand's economy has been based on agriculture, but the service sector is becoming increasingly important. In 1980, agriculture accounted for $23 \%$ of the GDP and manufacturing accounted for $21 \%$. By 1990, agriculture had dropped to $12 \%$ of GDP and manufacturing had grown to $26 \%$.

The average rate of inflation was $4.5 \%$ from 1980 to 1990 .

In 1990 , exports totaled US $\$ 28,881$ million and imports totaled US $\$ 32,692$ million. Over the period 1980 to 1990 , this represents an average annual growth rate for exports of $26.6 \%$ and an average annual growth rate for imports of $18.1 \%$.

Thailand's exports are well diversified. The largest export is textiles, followed by electronics, electrical appliances, rice, rubber, tapioca, processed food, integrated circuits, jewelry, footwear, furniture, and plastics. Thailand also exports mineral products, including tin, zinc, and gemstones. Thailand's imports are concentrated in capital goods for industrial projects. There are also substantial imports of petroleum, chemicals, iron, vehicles, parts, and scientific instruments.

Export-based industrial investment from Japan and the Republic of China contributed to the recent period of intense economic growth. In 1990, foreign investment totaled US\$15 billion. Reasons for this investment include a stable currency, a diversified economic base, and abundant cheap labor.

United States investment in Thailand is highly concentrated. About 20 firms account for $80 \%$ of the $\$ 3$ billion in investment. Fifty percent of U.S. investment was in the energy sector.

Japan also was Thailand's leading trading partner, having US\$14.1 billion in total trade. The United States was Thailand's second largest trading partner, having US\$8.9 billion in total trade. The United States is the largest market for Thailand manufactured products. During 1991, the U.S. trade deficit with Thailand reached US\$1.8 billion.

Thailand has taken steps to attract foreign investment; for example, the Board of Investment (BOI) grants various tax incentives to projects that meet national objectives. In 1990, the Thai government planned to replace the current business tax, reduce import duties on raw materials, and eliminate the BOI tax incentives. These measures are hoped to boost the manufacturing and trading sectors of the economy. 
In 1990, the Thai government took steps to adjust to the economic climate following the Persian Gulf crisis. The government liberalized foreign exchange controls and raised interest rates. Energy policies changed, and oil prices increased to diversify the country's energy needs. These measures helped the Thai economy survive a mild recession and continue its growth.

The National Economic and Social Development Board of Thailand predicts Thailand's economy will grow $7.6 \%$ during 1992. Exports should rise 15\%. Private investment should increase $3 \%$ to $5 \%$. The inflation rate should be close to $4.5 \%$, and the trade deficit is expected to be $11.0 \%$.

\section{Energy Use and Policy Issues}

During 1981 to 1991 , Thailand's final energy consumption nearly doubled to 30.5 million tons of oil equivalent (Mtoe). Continued economic growth is expected to double energy consumption again by the year 2000 .

In 1991, Thailand's total primary energy supply amounted to $43.9 \mathrm{Mtoe}$, an increase of $6.4 \%$ over the previous year, of which $58 \%$ came from indigenous sources and $42 \%$ from imported sources. Crude oil and other petroleum products accounted for $98 \%$ of the total energy imported totaling 19 Mtoe in 1991. Domestic energy was supplied by conventional energy (57.1\%) and renewable energy (42.9\%). Most of the renewable energy was biomass from firewood, paddy husk, and bagasse, totaling 10.9 Mtoe.

Per capita primary energy consumption equaled 758 kilograms of oil equivalent (kgoe) in 1991. For the period of 1980 to 1991 , energy consumption grew at an annual rate of $10 \%$.

In 1990, energy consumption was concentrated in three main sectors: transportation, residential, and industrial. The transportation sector used 11.9 Mtoe or $39.1 \%$ of Thailand's final energy consumption. The residential and commercial sectors used $23.7 \%$ of final energy consumption; renewable energy supplied $59.4 \%$ of the energy to these sectors. Industry consumed $30.4 \%$ of Thailand's energy, a rise of $8.7 \%$ over $1990 ; 32.2 \%$ of the manufacturing energy consumption was renewable energy.

Thailand's total installed electricity generation capacity was 9,707 megawatts (MW) in 1991, up 11.2\% over 1990 . Industry consumed $45.7 \%$ of the electricity, followed by commercial uses $(32.2 \%)$, and residential uses (21.1\%). An electricity tariff includes both peak and off-peak prices.

In 1973, the government adopted a plan for rural electrification, which proposed the electrification of all villages by the end of the century. By 1981, more than 5,000 villages per year were being electrified; in 1987, the plan was revised to electrify 19,000 more villages by 1991 .

At least seven government organizations are active in the Thai energy situation:

- The Ministry of Prime Minister Office's National Energy Policy Office, the secretariat of the National Energy Policy Council shared by the prime minister, recommends energy policy to the council. The Electricity Generating Authority of Thailand (EGAT) generates electricity.

- The Ministry of Science, Technology and Environment (MOSTE) supervises the Department of Energy Development and Promotion (DEDP). The DEDP implements new and renewable energy development and energy conservation policy. 
- The Ministry of Industry's (MOI) Department of Mineral Resources (DMR) regulates oil and gas supply. The Petroleum Authority of Thailand (PTT) supplies oil and gas. The Provincial Electrical Authority (PEA) and the Metropolitan Electrical Authority (MEA) distribute electricity.

- The Ministry of Commerce licenses petroleum-products traders.

- The Royal Forestry Department in the Ministry of Agriculture regulates issues related to fuelwood supply.

The private sector is very involved in oil and gas exploration and owns about $50 \%$ of the refining capacity within Thailand. The electricity sector is almost wholly owned by the public sector.

Energy policies in the Seventh National Economic and Social Development Plan (1992 to 1996) pursue the following goals:

- Stable energy supply at appropriate prices

- Efficient use and conservation

- Increased private role and unification of governmental systems in energy management.

\section{Energy Efficiency and Conservation}

In January of 1989 , the government began looking seriously at conservation as a solution to the electricity demand problem. A detailed work plan was proposed in January of 1990 to improve energy efficiency in all market sectors. The major recommendations included the establishment of the Energy Conservation Center of Thailand, low-interest-rate loans for energy-efficiency improvements, public relations and information campaigns, and tax reductions and financial support for conservation equipment.

Beginning with the Fifth National Plan (1982 to 1986), the Thai program has been aimed primarily at promoting energy efficiency in the industrial sector. The focal agency for this activity is DEDP. In the Sixth Plan, conservation activities in commercial and residential buildings were added. Based on the experience of DEDP and related agencies, the following are the chief problems that slow progress in conservation:

- Low energy prices due to low taxation

- Insufficient public awareness of the benefits of conservation

- Lack of public information on how to implement conservation measures

- Lack of interest in energy audits, perhaps based on a fear of loosing commercially confidential information

- Even after audits are conducted, an unwillingness to invest (probably because of the desire of business owners to respond to production orders or to gain market shares)

- Insufficient energy conservation training 
- Small budget for energy efficiency compared with the production budget

- Lack of sufficiently skilled people (technical and engineering) to implement needed changes in factories.

In response, government programs have concerns about information programs, incentives, training, and new regulations and laws. A substantial increase in petroleum taxation is only a remote possibility at the moment because of the lack of public support for such a policy.

Energy audits of 695 factories and 210 buildings were conducted to identify problems and recommend measures. Technical publications were prepared, along with pamphlets, posters, and newsletters, which are distributed to concerned organizations. Video and TV also were used in the last two years.

Energy conservation training seminars regarding fuel and electricity savings and energy management were provided to more than 4,000 persons from factories, buildings, and governmental organizations. Studies were conducted on various topics, including high-efficiency lights, ballasts, freezers, and building codes.

Since 1983, duties have been reduced on 138 items of imported energy equipment, for a total of 318 million baht. Since 1984, low-interest loans have been given to eight factories that serve as energy conservation demonstration sites. The total of the loans is 8.7 million baht.

In 1985, with the cooperation of DEDP and the Federation of Thai Industry (a nongovernmental organization that represents Thailand industries), the government established the Energy Conservation Center of Thailand (ECCT). ECCT's objective is to promote and provide services to energy conservation programs in the industrial sector.

An energy conservation law was announced in early 1992. It represents a very aggressive approach to energy conservation in industrial factories and buildings and in setting standards for energy-efficient equipment.

Facilities that have energy demand equal to or higher than $1 \mathrm{MW}$ or 20 million megajoules (MJ) are designated facilities that are required to hire qualified energy managers and to improve efficiency of energy use (electricity and process heat) through improving the efficiency of fuel burning, reducing energy losses, recycling waste energy, and using high-efficiency machines, etc. Owners are required to inspect their facilities, analyze energy use, and establish goals and a plan for achieving energy conservation. The plan must be submitted to DEDP.

Similarly, building owners are required to pursue actions to reduce solar loading on buildings; use efficient air conditioning to maintain proper indoor temperatures; and use energy-conserving building materials, equipment, and lighting. Minister orders specifying standards for air conditioning and water heating equipment; other building materials also are authorized.

Standards will be set for energy-using machinery and equipment; distributors and producers of such equipment will receive investment incentive and promotion assistance from the government.

After three years, those not in compliance are subjected to special fees being levied on their electricity consumption. 
An Energy Conservation and Development Fund was established recently; the funding will come from a variety of sources, including transferred money from the Oil Fund, special fees associated with noncompliance with the law, and fees on oil production. One and one-half billion baht was transferred from the Oil Fund to the Energy Conservation Fund. And 0.07 baht from every liter of gasoline, diesel, fuel oil, and kerosene sold in the country was collected and put into the fund since November 1992. This will contribute approximately 1.5 billion baht to the fund annually. The fund will be used to make grants and provide financial incentives that encourage the investment in operating facilities to save energy and solve environmental problems associated with energy use. It also will provide grants to encourage research and development in the areas of clean energy and energy conservation technologies.

EGAT is implementing a five-year Master Plan for demand-side management (DSM), which will demonstrate electricity conservation projects, build organizational capability to deliver large-scale DSM programs, and increase the involvement of utilities in environmental protection. The proposed budget for the program was 4.57 billion baht, for an estimated saving of $225 \mathrm{MW}$ of capacity and 2,000 MW of additional capacity over 10 years. The 4.57 billion baht will be used to provide incentives to homeowners, businesses, and industry to buy more efficient electricity-using technologies. The budget also includes funds to train utility management and technical staff-marketing the DSM programs to consumers, program management, and local management research. The first two years of the plan will consist of planning and pilot projects to provide information about energy-saving technologies and program strategies. Years three to five, and thereafter, will see full-scale implementation of the program.

Two government agencies (Department of Energy Development and Promotion; Thailand Institute for Scientific and Technological Research) have conducted work on R\&D on several renewable energy technologies: microhydro, PV for lighting, solar drying, wind turbines for water pumping, energyefficient stoves, rice-husk-burning stoves, biogas digesters, rice husk briquets, and an alcohol production pilot plant.

EGAT includes renewable energy in the long-term plan for Thailand's energy sector. At this time, the program consists of geothermal, solar, wind, biomass, and fluidized bed combustion. The government also has proposed energy conservation as part of the solution to Thailand's spiraling energy demand.

King Mongkut's Institute of Technology Thornburi (KMITT) organized the membrane technology group to research and develop polymeric and ceramic membranes. The group researched ultrafiltration and reverse osmosis membranes, developed membrane casting techniques, and produced ceramic membranes. KMITT also has studied the use of membranes in agro-industrial waste effluent, developed mathematical models of membrane processes, and formed a literature data base on membrane technology for ASEAN researchers.

The Biotechnology Engineering Center (BEC) develops biosensors, instrumentation, and control mechanisms for use in bioprocessing. Some of the past projects included robotic controls, computerized data acquisition for a soy flour plant, and liquid chromatography for sugar analysis.

Other research activities at KMITT include

- Enzyme technology

- Bioreactor design 
- Bioleaching and metal extraction

- Pilot plant development and training institute

- Algal biotechnology

- Genetic engineering

- Training courses

- International cooperation projects.

KMITT started research activities on biogas technology in 1979. It has worked with other ASEAN researchers and the ASEAN-Australia Economic Cooperation Program to develop high- efficiency bioreactors that produce biogas from agricultural wastes. KMITT researchers have studied organic wastes and different types of reactors; they have developed pilot reactors ranging from 30 to 200 liters.

In 1985, 5,000 family-sized biogas digesters were generating 1 to $2 \mathrm{~m}^{3}$ of biogas per day. Ten community-sized digesters were operating, and studies were being conducted for biogas use in agro-industrial plants. These plants use a variety of fuels, including rice husks, corn cobs, and sugar cane. The NEA and the United States Agency for International Development funded the majority of the newest plants.

\section{Bibliography}

The Energy Conservation Promotion Act (Draft)

Annual Report 1990; Electricity Generating Authority of Thailand

EGAT's Role in New Energy; Jivacate Chaya et al.

Electric Power in Thailand 1990; National Energy Administration, Ministry of Science, Technology and Energy

Electricity Savings Plan for the Industrial Commercial Residential Sectors; Thailand National Energy Administration, Ministry of Science, Technology and Energy; January 1990

\section{Energy Conservation Activity in Thailand}

Finesse Workshop, Financing of Energy Services for Small-Scale Energy Users, Country Market Study-Thailand; Charit Tingsabadh, Phol Sagetong, Somchai Ratanakomut, Mark Cherniack, Peter Brimble, Peter du Pont; Asian and Pacific Development Centre; October, 1991

Oil and Thailand 1990; National Energy Administration, Ministry of Science, Technology, and Energy

Thailand Energy Situation 1990; National Energy Administration, Ministry of Science, Technology, and Energy

Thailand: Asia Pacific Energy Series: Country Report; David Fridley, Energy Program Resource Systems Institute; November 1988 


\begin{tabular}{|c|c|}
\hline $\begin{array}{l}\text { Title: Energy Conservation Demonstration } \\
\text { Program }\end{array}$ & Project Type: Study/demonstration \\
\hline $\begin{array}{l}\text { Organization: National Energy Administration } \\
\text { (NEA) }\end{array}$ & Date: 1984 to present \\
\hline End-use Sector: Industry & $\begin{array}{l}\text { Affiliated/Future Projects: October } 1986 \\
\text { expansion of the program included energy } \\
\text { substitution by domestic sources, conservation } \\
\text { in commercial buildings, and production of } \\
\text { energy-efficient equipment. }\end{array}$ \\
\hline $\begin{array}{l}\text { Description: Demonstration projects in eight } \\
\text { food, paper, fabricated metals, and textile } \\
\text { factories to encourage implementation of energy } \\
\text { conservation in industries. }\end{array}$ & Technology: Various \\
\hline $\begin{array}{l}\text { Results: Estimated annual conservation from } \\
\text { eight factories is } 7.84 \text { million liters of fuel oil; } \\
0.85 \text { million } \mathrm{kWh} \text { of electricity. }\end{array}$ & $\begin{array}{l}\text { Reference: ASEAN-EC Energy Conservation } \\
\text { Seminar, December } 1987\end{array}$ \\
\hline
\end{tabular}

\begin{tabular}{|c|c|}
\hline Title: Energy Conservation Unit & Project Type: Audit \\
\hline $\begin{array}{l}\text { Organization: National Energy Administration } \\
\text { (NEA) }\end{array}$ & Date: 1982 to present \\
\hline End-use Sector: Industry & $\begin{array}{l}\text { Affiliated/Future Projects: Training courses } \\
\text { on energy conservation are regularly presented } \\
\text { to factory managers, engineers, and technicians } \\
\text { through the Energy Training Center of the } \\
\text { NEA. }\end{array}$ \\
\hline $\begin{array}{l}\text { Description: Examination and analysis of the } \\
\text { potential for energy conservation in } 285 \\
\text { factories to date. }\end{array}$ & Technology: Various \\
\hline Results: N. A. & $\begin{array}{l}\text { Reference: ASEAN-EC Energy Conservation } \\
\text { Seminar }\end{array}$ \\
\hline
\end{tabular}




\begin{tabular}{|c|c|}
\hline $\begin{array}{l}\text { Title: National Energy Saving Goals for } \\
\text { Industry }\end{array}$ & Project Type: Study/demonstration \\
\hline $\begin{array}{l}\text { Organization: National Energy Administration } \\
\text { (NEA) }\end{array}$ & Date: 1986 \\
\hline End-use Sector: Industry & Affiliated/Future Projects: None \\
\hline $\begin{array}{l}\text { Description: Study on technical potential for } \\
\text { energy savings. }\end{array}$ & Technology: Various \\
\hline $\begin{array}{l}\text { Results: The study recommends that technical } \\
\text { potential be achieved by implementing changes } \\
\text { in housekeeping, process improvement } \\
\text { measures, and major equipment. }\end{array}$ & $\begin{array}{l}\text { Reference: ASEAN-EC Energy Conservation } \\
\text { Seminar, December } 1987\end{array}$ \\
\hline
\end{tabular}

\begin{tabular}{l:l}
\hline Title: Industrial Energy Conservation in & Project Type: Policy assessment \\
Thailand & Date: Ongoing \\
\hdashline Organization: Thai government, National \\
Energy Administration (NEA), and the Energy \\
Conservation Center of Thailand (ECCT)
\end{tabular}




\begin{tabular}{|c|c|}
\hline $\begin{array}{l}\text { Title: ASEAN-Australian Economic } \\
\text { Cooperation Programme (AAECP) for Food } \\
\text { Waste Materials }\end{array}$ & Project Type: R\&D; tech transfer \\
\hline $\begin{array}{l}\text { Organization: AAECP, King Mongkut's } \\
\text { Institute of Technology Thornburi (KMITT) }\end{array}$ & Date: 1988 \\
\hline End-use Sector: Industry & $\begin{array}{l}\text { Affiliated/Future Projects: KMITT research } \\
\text { activities. There are at least } 5,000 \text { biogas } \\
\text { systems in Thailand. }\end{array}$ \\
\hline $\begin{array}{l}\text { Description: AAECP sponsored a working } \\
\text { group to perform cooperative research to } \\
\text { develop technology for converting organic } \\
\text { wastes into useful products. }\end{array}$ & Technology: Biogas reactors \\
\hline $\begin{array}{l}\text { Results: KMITT developed high-efficiency } \\
\text { biogas reactors and an industrial biogas pilot } \\
\text { plant. }\end{array}$ & Reference: RERIC News \\
\hline
\end{tabular}

\begin{tabular}{|c|c|}
\hline $\begin{array}{l}\text { Title: Tapioca Starch Waste Treatment Water } \\
\text { Project }\end{array}$ & Project Type: Study/demonstration \\
\hline $\begin{array}{l}\text { Organization: King Mongkut's Institute of } \\
\text { Technology Thornburi (KMTT) }\end{array}$ & Date: Since 1988 \\
\hline End-use Sector: Industry & $\begin{array}{l}\text { Affiliated/Future Projects: KMITT biogas } \\
\text { research }\end{array}$ \\
\hline $\begin{array}{l}\text { Description: The Ministry of Science, through } \\
\text { the National Center for Genetic Engineering, } \\
\text { provides } 4.0 \text { million baht for research treatments } \\
\text { of tapioca starch wastewater. }\end{array}$ & Technology: Biogas \\
\hline $\begin{array}{l}\text { Results: The Ban Pong Tapioca Starch } \\
\text { Industrial Co. Ltd. built a } 160-\mathrm{m}^{3} \text { capacity filter } \\
\text { bed biogas plant and four high rate } 118-\mathrm{m}^{3} \\
\text { capacity algae tanks. Methane is used to dry } \\
\text { tapioca starch. }\end{array}$ & Reference: RERIC News \\
\hline
\end{tabular}




\begin{tabular}{|l|l|}
\hline Title: Industrial Solar Fruit Dryer & Project Type: Study/demonstration \\
\hdashline Organization: KMITT, AIT, NUTEC & Date: 1991 \\
\hdashline End-use Sector: Industry & Affiliated/Future Projects: \\
\hdashline $\begin{array}{l}\text { Description: Three industrial-scale solar fruit } \\
\text { dryers were developed. }\end{array}$ & $\begin{array}{l}\text { Technology: The dryer consists of a solar } \\
\text { collector plate, a burner for biomass, a heat } \\
\text { exchanger, and two dryer cabinets. }\end{array}$ \\
\hdashline $\begin{array}{l}\text { Results: } \\
\text { compared with conventional ovens. }\end{array}$ & Reference: RERIC News \\
\hline
\end{tabular}

\begin{tabular}{|c|c|}
\hline Title: Rural Renewable Energy Project & Project Type: R\&D \\
\hline $\begin{array}{l}\text { Organization: Brace Research Institute of } \\
\text { McGill University, Canada and Khon Kaen } \\
\text { University, Thailand }\end{array}$ & Date: Research cooperation \\
\hline End-use Sector: Utility (rural electrification) & $\begin{array}{l}\text { Affiliated/Future Projects: August } 1987 \text { to } \\
\text { March } 1992\end{array}$ \\
\hline $\begin{array}{l}\text { Description: The two universities developed a } \\
\text { linkage program to develop renewables in rural } \\
\text { Thailand. The program planned staff } \\
\text { exchanges, research transfer, training for energy } \\
\text { monitoring, R\&D into renewable technologies, } \\
\text { field projects, field training, an information } \\
\text { campaign, and an information exchange. }\end{array}$ & $\begin{array}{l}\text { Technology: The agreement will cover the } \\
\text { following technologies: (1) biogas, a feasibility } \\
\text { study for tice hull gasification plant in Northern } \\
\text { Thailand and biogas lab/workshop fabrication; } \\
\text { (2) biomass, a charcoal/wood stove study to } \\
\text { design more efficient stoves, and (3) solar, solar } \\
\text { food processing, nocturnal coolers, and solar } \\
\text { cookers. }\end{array}$ \\
\hline $\begin{array}{l}\text { Results: The project completed } 39 \text { staff } \\
\text { exchanges, a project library, and tests on solar } \\
\text { disinfection of water. The project developed } \\
5-\mathrm{kW} \text { and } 15-\mathrm{kW} \text { gasifiers, a solar steamer for } \\
\text { rice, and improved wood stoves. }\end{array}$ & Reference: RERIC News \\
\hline
\end{tabular}




\begin{tabular}{|c|c|}
\hline Title: Solar-Powered School in S. Thailand & Project Type: Study/demonstration \\
\hline Organization: BP Solar, Thai government & Date: 1991 \\
\hline End-use Sector: Utility (Rural electrification) & $\begin{array}{l}\text { Affiliated/Future Projects: Fourteen more } \\
\text { panels will be installed to supply battery } \\
\text { charging to villagers. }\end{array}$ \\
\hline $\begin{array}{l}\text { Description: A Japanese monastery donated } \\
\text { solar panels to the Baan Sai Kao School in } \\
\text { Chumphon. }\end{array}$ & Technology: Photovoltaic \\
\hline $\begin{array}{l}\text { Results: BP Solar Thai installed } 60 \text { modules } \\
\text { that deliver an average power of } 20 \mathrm{~kW} \text { per day. }\end{array}$ & Reference: RERIC News \\
\hline
\end{tabular}

\begin{tabular}{l|l|}
\hline Title: Household-Scale Charcoal Gasifier & Project Type: Study/demonstration \\
\hdashline $\begin{array}{l}\text { Organization: Songkla University, University } \\
\text { of Bangkok, USAID }\end{array}$ & Date: 1985 \\
\hdashline End-use Sector: Residential building & Affiliated/Future Projects: There are at least \\
& 5,000 biogas systems in Thailand. \\
\hdashline Description: USAID funded the design and \\
construction of a charcoal gasifier power \\
system.
\end{tabular}


Title: Geothermal Energy Projects

Organization: Electricity Generating Authority of Thailand (EGAT), Department of Mineral Resources, and Chiang Mai University

End-use Sector: Renewable energy

Description: EGAT is interested in renewable energy technologies. Its strategy is to use foreign experts to help local institutions.

Results: EGAT completed a feasibility study of the San Kampaeng geothermal field and completed a $300-\mathrm{kW}$ binary cycle demonstration plant.
Project Type: R\&D; study/demo

Date: Since the 1970s

Affiliated/Future Projects: San Kamphaeng Geothermal Energy Project, Fang Geothermal Power Plant, cool storage using geothermal fluid

Technology: Geothermal

Reference: RERIC News, EGAT Alternative Energy Technology Status

\begin{tabular}{l|l|}
\hline $\begin{array}{l}\text { Title: San Kamphaeng Geothermal Energy } \\
\text { Project }\end{array}$ & Project Type: R\&D; study/demo \\
\hdashline Organization: EGAT, Department of Mineral & Date: Since 1977 \\
Resources, and Chiang Mai University & \\
\hdashline End-use Sector: Renewable energy & Affiliated/Future Projects: \\
\hdashline Description: Geothermal exploration & Technology: Geothermal \\
\hdashline $\begin{array}{l}\text { Results: The project dug six geothermal wells } \\
\text { having depths up to } 500 \mathrm{~m} \text {. In cooperation with }\end{array}$ & \\
Japan, a 1500-m well was dug in 1986.
\end{tabular}

Title: Solar Kiln in Thailand

Organization: Asian Institute of Technology, Thai Plywood Company (TPC)

End-use Sector: Renewable energy

Description: TPC constructed the biggest solar kiln in Thailand as a pre-drying system to minimize total drying time of timber for use as door frames.

Results: The performance is being investigated to determine drying schedules. TPC developed a mathematical model to predict drying rate.

\section{Project Type: Study/demonstration}

Date: 1988

\section{Affiliated/Future Projects:}

Technology: A 20- $\mathrm{m}^{3}$ kiln using passive solar is covered with low density polyethylene foam; four fans circulate air.

Reference: RERIC News 


\begin{tabular}{|c|c|}
\hline Title: AIT-GTZ Biocoal Project & Project Type: R\&D; study/demo \\
\hline $\begin{array}{l}\text { Organization: Asian Institute of Technology, } \\
\text { German Agency for Technical Cooperation }\end{array}$ & Date: Since 1987 \\
\hline $\begin{array}{l}\text { End-use Sector: Industry; commercial, } \\
\text { residential building }\end{array}$ & $\begin{array}{l}\text { Affiliated/Future Projects: There are at least } \\
5,000 \text { biogas systems in Thailand. }\end{array}$ \\
\hline $\begin{array}{l}\text { Description: The project studied biocoal } \\
\text { utilization and opportunities in Thailand. }\end{array}$ & Technology: Biocoal manufacturing \\
\hline $\begin{array}{l}\text { Results: The project published reports on state- } \\
\text { of-the-art biocoal technology: A Comparison of } \\
\text { Options for Producing Biocoal, Economic } \\
\text { Report for Biocoal in Thailand, Test Run of } \\
\text { Biocoal Kiln in Thailand, Market Opportunities } \\
\text { in Thailand. }\end{array}$ & Reference: RERIC News \\
\hline
\end{tabular}

\begin{tabular}{|c|c|}
\hline $\begin{array}{l}\text { Title: Energy Conservation Activity in } \\
\text { Thailand }\end{array}$ & Project Type: Policy assessment \\
\hline $\begin{array}{l}\text { Organization: Thai government, National } \\
\text { Energy Administration (NEA), Energy } \\
\text { Conservation Center of Thailand (ECCT) }\end{array}$ & Date: 1992 to 1996 \\
\hline End-use Sector: All sectors & $\begin{array}{l}\text { Affiliated/Future Projects: Activities at the } \\
\text { National Energy Administration, Energy } \\
\text { Conservation Center of Thailand, Technological } \\
\text { Promotion Association, Industrial Finance } \\
\text { Corporation, and various universities }\end{array}$ \\
\hline $\begin{array}{l}\text { Description: Thailand has an energy } \\
\text { conservation policy in its seventh national plan } \\
\text { (1992 to 1996). It calls for energy pricing } \\
\text { policy to reduce investment in energy } \\
\text { production; improved petroleum pricing to } \\
\text { reflect true economic cost; laws to encourage } \\
\text { efficiency; and a stronger role for energy } \\
\text { conservation organizations. }\end{array}$ & $\begin{array}{l}\text { Technology: Conservation. The NEA and the } \\
\text { ECCT conducted energy audits of } 695 \text { factories } \\
\text { and } 210 \text { buildings, provided an energy } \\
\text { conservation training program, provided low } \\
\text { interest-rate loans to eight factories for } \\
\text { conservation, reduced import tariffs on } \\
\text { conservation equipment, provided technical } \\
\text { information, and studied high-efficiency } \\
\text { systems. }\end{array}$ \\
\hline $\begin{array}{l}\text { Results: The government has implemented } \\
\text { energy conservation since the fifth national plan } \\
\text { (1982 to 1986). }\end{array}$ & Reference: Energy Conservation in Thailand \\
\hline
\end{tabular}




\begin{tabular}{|c|c|}
\hline $\begin{array}{l}\text { Title: National Energy Administration's (NEA) } \\
\text { Conservation Activities }\end{array}$ & Project Type: Policy assessment \\
\hline Organization: NEA & Date: Ongoing \\
\hline End-use Sector: All sectors & $\begin{array}{l}\text { Affiliated/Future Projects: The NEA } \\
\text { promotes energy conservation through the } \\
\text { Energy Conservation Center of Thailand } \\
\text { (ECCT). }\end{array}$ \\
\hline $\begin{array}{l}\text { Description: The NEA activities include } \\
\text { identifying energy conservation potential; } \\
\text { formulating energy policy; and providing } \\
\text { research, energy audits, training, and incentives } \\
\text { for conservation. }\end{array}$ & Technology: Conservation \\
\hline $\begin{array}{l}\text { Results: In January of } 1990 \text {, an Electricity } \\
\text { Savings Plan for Industrial, Commercial, and } \\
\text { Residential Sectors outlined a three-year plan to } \\
\text { save } 159 \text { MW. The government rejected the } \\
\text { plan. In other areas, the NEA has trained } \\
\text { factory personnel. }\end{array}$ & Reference: Energy Conservation in Thailand \\
\hline
\end{tabular}

\begin{tabular}{|c|c|}
\hline Title: Water Pumping Gasifier & Project Type: Study/demonstration \\
\hline $\begin{array}{l}\text { Organization: USAID, Songkla University, } \\
\text { International Foundation for Science }\end{array}$ & Date: 1985 \\
\hline End-use Sector: Utility & $\begin{array}{l}\text { Affiliated/Future Projects: There are at least } \\
5,000 \text { biogas systems in Thailand. }\end{array}$ \\
\hline $\begin{array}{l}\text { Description: USAID funded the university to } \\
\text { build a charcoal gasifier to pump water in an } \\
\text { unelectrified village. }\end{array}$ & Technology: Biogas \\
\hline $\begin{array}{l}\text { Results: A charcoal gasifier powered a } \\
\text { 5-horsepower engine to pump water for the } \\
\text { village. }\end{array}$ & Reference: Bioenergy Systems Report \\
\hline
\end{tabular}




\begin{tabular}{|c|c|}
\hline Title: Biogas Data Base & Project Type: R\&D \\
\hline $\begin{array}{l}\text { Organization: King Mongkut's Institute of } \\
\text { Technology Thornburi, (KMITT) Bangkok }\end{array}$ & Date: 1988 \\
\hline End-use Sector: All sectors & $\begin{array}{l}\text { Affiliated/Future Projects: KMITT biogas } \\
\text { research }\end{array}$ \\
\hline $\begin{array}{l}\text { Description: A regional data base was set up at } \\
\text { the KMITT library to track biogas projects, } \\
\text { research, and developments. }\end{array}$ & $\begin{array}{l}\text { Technology: There are at least } 5,000 \text { biogas } \\
\text { systems in Thailand. }\end{array}$ \\
\hline $\begin{array}{l}\text { Results: As of } 1988,1,500 \text { articles were } \\
\text { collected. }\end{array}$ & Reference: RERIC News \\
\hline
\end{tabular}

\begin{tabular}{|c|c|}
\hline $\begin{array}{l}\text { Title: FINESSE (Financing Energy Services for } \\
\text { Small-Scale Energy Users) }\end{array}$ & Project Type: Policy assessment \\
\hline $\begin{array}{l}\text { Organization: The World Bank, U.S. } \\
\text { Department of Energy, USAID, U.S. } \\
\text { Environmental Protection Agency, UNDP, Asian } \\
\text { Development Bank, Asian and Pacific } \\
\text { Development Center, Netherlands Ministry of } \\
\text { Foreign Affairs }\end{array}$ & Date: FINESSE was launched in 1989. \\
\hline End-use Sector: All sectors & Affiliated/Future Projects: Unknown \\
\hline $\begin{array}{l}\text { Description: Project FINESSE was launched to } \\
\text { conduct market studies, promote the manu- } \\
\text { facture of energy-efficient light bulbs and } \\
\text { appliances, examine the institutional } \\
\text { environment for alternative energy projects, } \\
\text { establish ASEAN project opportunities, establish } \\
\text { a multidonor feasibility fund, and host } \\
\text { international conferences. }\end{array}$ & Technology: All renewable energy \\
\hline $\begin{array}{l}\text { Results: FINESSE has completed market } \\
\text { studies on Malaysia, the Philippines, Indonesia, } \\
\text { and Thailand. The studies identified project } \\
\text { opportunities for renewable energy. }\end{array}$ & $\begin{array}{l}\text { Reference: FINESSE Country Market Studies, } \\
\text { FINESSE Report }\end{array}$ \\
\hline
\end{tabular}




\begin{tabular}{|c|c|}
\hline $\begin{array}{l}\text { Title: Energy Conservation Center of Thailand } \\
\text { (ECCT) }\end{array}$ & Project Type: Education/information \\
\hline $\begin{array}{l}\text { Organization: ECCT is privately managed } \\
\text { under National Energy Administration } \\
\text { supervision. }\end{array}$ & Date: 1986 to present \\
\hline End-use Sector: All sectors & Affiliated/Future Projects: Various \\
\hline $\begin{array}{l}\text { Description: ECCT was established to promote } \\
\text { and strengthen energy conservation. }\end{array}$ & Technology: Various \\
\hline Results: N. A. & $\begin{array}{l}\text { Reference: ASEAN-EC Energy Conservation } \\
\text { Seminar, December } 1987\end{array}$ \\
\hline
\end{tabular}

\begin{tabular}{|c|c|}
\hline Title: The Energy Conservation Promotion Act & Project Type: Policy assessment \\
\hline $\begin{array}{l}\text { Organization: Thai government, National } \\
\text { Energy Administration (NEA), Energy } \\
\text { Conservation Center of Thailand (ECCT) }\end{array}$ & Date: 1991 \\
\hline End-use Sector: All sectors & $\begin{array}{l}\text { Affiliated/Future Projects: NEA and ECCT } \\
\text { activities }\end{array}$ \\
\hline $\begin{array}{l}\text { Description: The act gives the Minister of } \\
\text { Science, Technology, and Energy power to } \\
\text { promote conservation, calls for the appointment } \\
\text { of energy managers for all controlled factories, } \\
\text { starts a fund from an oil tax for conservation } \\
\text { under the Ministry of Finance, and sets methods } \\
\text { to prosecute violators of the law. }\end{array}$ & Technology: Conservation \\
\hline Results: The law was passed. & $\begin{array}{l}\text { Reference: Draft copy of the Energy } \\
\text { Conservation Act }\end{array}$ \\
\hline
\end{tabular}

\begin{tabular}{|c|c|}
\hline Title: Energy Conservation Information Service & Project Type: Policy assessment \\
\hline Organization: National Energy Administration & Date: 1982 ; continuing \\
\hline End-use Sector: All sectors & Affiliated/Future Projects: Various \\
\hline $\begin{array}{l}\text { Description: The service provides information } \\
\text { on conservation. }\end{array}$ & Technology: Conservation \\
\hline Results: N. A. & $\begin{array}{l}\text { Reference: ASEAN-EC Energy Conservation } \\
\text { Seminar }\end{array}$ \\
\hline
\end{tabular}




\section{United States}

The United States occupies the central part of North America and has a total area of 9,373 thousand $\mathrm{km}^{2}$. The population of 240 million people is geographically dispersed, requiring its people to drive farther for commerce and leisure than do people in most other countries. The modern infrastructure of U.S. cities, highways, and industries was developed with abundant and relatively inexpensive energy resources. Two-thirds of the 90 million U.S. households live in single-family homes, which are more energy intensive than multifamily structures.

The continuing national dependence on oil arises from the use of motor fuels to transport people and products. A little more than one-quarter of U.S. energy use and about two-thirds of all petroleum use are accounted for by the transportation sector. Overall, the pattern of energy use in the United States is commensurate with its large land area, low population density, and significant indigenous resources.

\section{Energy Use and Policy Issues}

The U.S. economy includes certain energy-intensive industries, such as steelmaking, that account for much of its industrial energy use. Nine of these industries account for $70 \%$ of the industrial energy use but less than $15 \%$ of the economic value of industrial output.

Electricity supplies nearly $70 \%$ of the energy used by the commercial buildings sector. Much of the recent growth in electricity use can be attributed to increasing use of air conditioners in commercial buildings. Besides electricity, natural gas is the other major fuel used in commercial buildings.

In recent years, many renewable energy resources, such as solar, wind, and geothermal power, have increased their respective contributions to the U.S. economy by very large percentages; however, except for biomass and hydroelectricity, they still represent very little input in absolute terms.

The U.S. government started funding research and development of renewable energy with $\$ 20$ million in 1974 . In the late 1970 s, this commitment increased to nearly $\$ 140$ million. In addition, tax credits for renewable energy systems also began in the late 1970 s.

In 1988, renewable energy provided $8 \%$ of the total energy supply. The resources used included hydropower (46\%), geothermal (4\%), biomass electric (7\%), biomass buildings (14\%), biomass industrial (26\%), and wind, PV, solar thermal, and alcohol fuels (3\%). Hydropower provided 71,533 megawatts (MW) of electricity-generating capacity in 1990. In at least five states, more than $40 \%$ of the electricity generated comes from hydropower.

In 1990, total energy use in the United States equaled 1,982.7 million tons of oil equivalent (Mtoe). This was supplied by oil $(40.1 \%)$, coal $(27.3 \%)$, gas $(22.3 \%)$, nuclear $(6.9 \%)$, and hydro $(3.3 \%)$. In 2000 , energy consumption is expected to be 2,192 Mtoe.

Per capita energy consumption equaled 7,822 kilograms of oil equivalent (kgoe) in 1990, up from 6,535 kgoe in 1965. For the period 1980 to 1990 , energy consumption grew at an annual rate of $1.5 \%$. For the years between 1965 and 1980, energy consumption grew at an anual rate of $2.3 \%$.

Crude oil production declined 18\% between 1986 and 1990. Total production in 1989 averaged 7.6 million barrels per day. Crude oil and product imports rose $8 \%$ from 1988 to 1989 , accounting for $41 \%$ of the U.S. supply. 
Natural gas production in 1988 rose slightly to 16.7 trillion $\mathrm{ft}^{3}$ (tcf), while gas consumption increased to 18 tcf. The United States imported about $6 \%$ of its gas from Canada and exported small quantities of liquefied natural gas to Japan.

The coal resources of the United States represent about $30 \%$ of the world's coal resources. In 1988, coal production reached a record 860 million metric tons and will continue to be the mainstay of domestic energy supply. The Department of Energy's (DOE) Clean Coal Technology Program funds $\$ 3.75$ billion of research and demonstrations to develop technology to keep coal clean, competitive, and convenient.

During 1988, U.S. utilities produced 2,701 billion kilowatt-hours of electricity generated by 743 gigawatts of installed capacity. Eighty percent of these utilities were investor owned, and they supplied almost $75 \%$ of the power generated. The electricity generation in 1989 came from coal $(56 \%)$, oil (5\%), natural gas (9\%), nuclear (19\%), and hydro (10\%). A small amount of electricity was imported. The development of private power was given new impetus by the passage of the Public Utilities Regulatory Policy Act in 1978. This legislation, under certain prescribed conditions, forces utilities to buy private power from nonutility producers.

\section{Energy Efficiency and Conservation}

The U.S. National Energy Strategy (NES) states that no feasible combination of domestic or international energy policy options can make the United States completely invulnerable to foreign oil supply disruptions during the foreseeable future and that reducing this vulnerability requires a broad array of actions.

Such actions include maintaining adequate strategic reserves, increasing U.S. petroleum production in an environmentally sensitive manner, and further deregulating the natural gas industry. The NES also aims to reduce the importance of oil to the U.S. economy through conservation, efficiency improvements, and oil displacement (using improved technologies and alternative fuels).

The United States has several laws on energy conservation. The main ones are the Energy Policy and Conservation Act of 1975, followed by the National Energy Conservation Policy Act of 1978. In 1987, a new National Act on the Efficiency of Appliances was adopted (revised in 1988).

New legislation, the Energy Policy Act of 1992, was signed into law by the President on October 24, 1992. The act is extremely wide ranging and includes many provisions dealing with increasing energy efficiency in housing and other buildings (including buildings owned by the U.S. government) and encourages investments in efficiency by both gas and electric utilities. In addition, the act establishes an electric vehicle commercial demonstration program.

The energy-efficiency gains in the United States between 1973 and 1985 are estimated to be 30\%, compared with the situation without energy-efficiency measures. Industrial sectors and households contributed most.

DOE is the main sponsor of energy-efficiency and renewable energy programs in the United States. At DOE, these programs are located in the Office of the Assistant Secretary for Energy Efficiency and Renewable Energy (EE). An important focus of these programs is research and development, but data analysis, planning, and technology transfer efforts support the research programs and increase the quantity and quality of information on energy conservation available to the public and U.S. industry. 
In EE, the building technologies programs are designed to improve the efficiency of the building envelope, the equipment used in buildings, and the community systems that deliver energy to the building. These programs also seek to stimulate the use of renewable energy in buildings and to develop methods of mitigating indoor air quality hazards without sacrificing energy efficiency.

The Energy Policy and Conservation Act of 1975, as amended, established an energy conservation program-including test procedures, labeling, and standards-for these 13 types of household appliances: refrigerators, refrigerator/freezers, and freezers; room air conditioners; central air conditioners and heat pumps; water heaters; furnaces; dishwashers; clothes washers; clothes dryers; direct heating equipment; kitchen ranges and ovens; pool heaters; television sets; and fluorescent ballasts. The act established a three-part program: test procedures, energy-conservation standards, and appliance labeling. The standards must be technologically feasible and economically justified. The labeling program is managed by the Federal Trade Commission. This program requires manufacturers to affix energy-efficiency labels to appliances to make consumers aware of the energy costs of operating them.

The transportation technologies programs are focused on three areas: (1) advanced automotive propulsion systems, including gas turbines, low heat rejection diesel, and electric vehicle technologies; (2) advanced materials development and tribology research; and (3) research, development, demonstration, testing and evaluation, including field testing in fleet operations, of alternative fuels.

The industrial technologies programs emphasize three major areas: (1) industrial process efficiency; (2) waste energy reduction, including energy lost in heat and material wastes; and (3) industrial heat and power generation.

The utility technologies programs deal with increasing the efficiency of the electric system and address the financial and regulatory problems of utilities and the question of how to increase the mix of renewable energy supply for utilities.

Finally, EE manages several programs designed to ease the way of new renewable energy and energyefficiency technologies into the marketplace. These programs are located in the Office of Technical and Financial Assistance (OTFA), which works cooperatively with state and local government energy offices and energy-related private and nonprofit organizations. This office provides technical and financial assistance to these groups and encourages their feedback regarding EE programs.

The overall management of the U.S. activities related to the International Energy Agency (IEA) Center for the Analysis and Dissemination of Demonstrated Energy Technologies (CADDET) also resides in this office. The program is assisted by experts from the other EE technology programs and by Oak Ridge National Laboratory, which is under contract to OTFA to support CADDET. Private sector participation, which is at the heart of the U.S. CADDET program, is generated through the activities of the U.S. CADDET National Team, consisting of officials from private companies, utility organizations, DOE national laboratories, federal agencies, state and local agencies, trade and professional organizations, universities, and information agencies. Many of these organizations fund and/or undertake their own energy conservation programs (e. g., the Electric Power Research Institute, the Gas Research Institute, and the State Energy Offices). 


\section{Bibliography}

A Compendium of Energy Conservation Success Stories 90; DOE/CH10093-83, Golden, CO: Solar Energy Research Institute; December 1990

National Energy Strategy Executive Summary, February 1991

Programs in Renewable Energy Fiscal Year 1989, U. S. Department of Energy 


\begin{tabular}{|l:l|}
\hline Title: Heat Transfer and Heat Exchangers & Project Type: R\&D \\
\hdashline $\begin{array}{l}\text { Organization: International Energy Agency } \\
\text { (IEA) (participants are United States and six } \\
\text { others) }\end{array}$ & Date: 1977; continuing \\
\hdashline End-use Sector: Industry & \\
\hdashline $\begin{array}{l}\text { Description: R\&D and assessments of heat } \\
\text { transfer and heat exchanger technology. }\end{array}$ & Technology: Heat exchangers \\
\hdashline $\begin{array}{l}\text { Results: Completed initial research into heat } \\
\text { transfer from extended surfaces, design of heat } \\
\text { exchanger networks, and vibration problems in } \\
\text { heat exchangers. Studied deposits that foul } \\
\text { surfaces; carried out tests in wind and water } \\
\text { tunnels to study sources of vibration. Research } \\
\text { results are available for application in industrial } \\
\text { process design. }\end{array}$ & \\
\hline
\end{tabular}

\begin{tabular}{|l:l|}
\hline $\begin{array}{l}\text { Title: Ceramic Recuperator Recovers Heat } \\
\text { from Exhaust Gas }\end{array}$ & Project Type: R\&D \\
\hdashline $\begin{array}{l}\text { Organization: Office of Industrial Programs, } \\
\text { Conservation and Renewable Energy, DOE }\end{array}$ & Date: 1982 \\
\hdashline End-use Sector: Industry (metals and mineral) & Affiliated/Future Projects: None \\
\hdashline $\begin{array}{l}\text { Description: Development of a ceramic } \\
\text { recuperator for industries with high-temperature } \\
\text { exhaust gas streams to produce energy savings. }\end{array}$ & $\begin{array}{l}\text { Technology: Ceramic matrix composed of } \\
\text { alternate layers of ceramic passages oriented at } \\
\text { right angles to each other; allows core to be } \\
\text { replaced or removed for easy cleaning and }\end{array}$ \\
\hdashline $\begin{array}{l}\text { Results: Energy savings were 40\% to 50\%. } \\
\text { This process is suitable for many industrial } \\
\text { applications and is durable at temperatures up to } \\
1425^{\circ} \mathrm{C} .\end{array}$ & $\begin{array}{l}\text { Reference: IEA Center for the Analysis and } \\
\text { Dissemination of Energy Technologies }\end{array}$ \\
\hline
\end{tabular}




\begin{tabular}{|c|c|}
\hline Title: Induction Heating and Melting & Project Type: R\&D \\
\hline $\begin{array}{l}\text { Organization: Electric Power Research } \\
\text { Institute }\end{array}$ & Date: 1989 \\
\hline End-use Sector: Industry (metal) & Affiliated/Future Projects: None \\
\hline $\begin{array}{l}\text { Description: Study of induction heating and } \\
\text { melting for production of iron and steel castings } \\
\text { to save energy and increase production. }\end{array}$ & $\begin{array}{l}\text { Technology: Design of coreless induction } \\
\text { furnace includes induction coil, insulating } \\
\text { refractory, refractory cement, and a crucible. } \\
\text { Design of channel induction furnace includes } \\
\text { inductor, insulating refractory, backup } \\
\text { refractory, and monolithic refractory. }\end{array}$ \\
\hline $\begin{array}{l}\text { Results: Project results included decreased } \\
\text { energy consumption per unit of product, higher } \\
\text { yield of high-quality products, cleaner melting, } \\
\text { improved working environment, declining } \\
\text { capital costs. Thermal efficiency is } 55 \%-65 \% \text {; } \\
\text { net dollar benefit from converting to induction } \\
\text { furnaces is } \$ 34,800 \text {. }\end{array}$ & Reference: IEA CADDET \\
\hline
\end{tabular}

\begin{tabular}{|c|c|}
\hline Title: Foam Processing & Project Type: R\&D \\
\hline $\begin{array}{l}\text { Organization: United Merchants } \\
\text { and Manufacturers, South Carolina }\end{array}$ & Date: 1989 to 2010 \\
\hline End-use Sector: Industry (textiles) & Affiliated/Future Projects: None \\
\hline $\begin{array}{l}\text { Description: Project to accelerate the } \\
\text { development of a more energy-efficient process } \\
\text { for the application of pigments and other } \\
\text { chemicals to textiles, and to disseminate the } \\
\text { benefits of the technology by using independent } \\
\text { energy audit sites within the textile industry. }\end{array}$ & $\begin{array}{l}\text { Technology: Concentrated mix of finishing } \\
\text { chemicals foamed by a mechanical or static } \\
\text { foam generator. Foam is then applied to } \\
\text { fabrics. Mechanical force causes collapse of } \\
\text { foam, distributing chemicals evenly through the } \\
\text { fabric. }\end{array}$ \\
\hline $\begin{array}{l}\text { Results: Project resulted in reduced energy for } \\
\text { drying, increased plant productivity, more } \\
\text { efficient utilization of chemicals, reduced water } \\
\text { consumption, and greater savings on pollution } \\
\text { abatement. }\end{array}$ & Reference: IEA CADDET \\
\hline
\end{tabular}


Title: Membrane Processes for Industrial Separation and Drying

Organization: Bend Research, Inc., Oregon

End-use Sector: Industry (separation and drying)

Description: This study determined the feasibility of developing membrane processes as energy-efficient alternatives to conventional treatment of wastewater streams in the cornsweetener industry.

Results: Reduces energy usage (50\%); increases waste energy recovery $(30 \%)$; versatile for many industrial applications.
Project Type: $R \& D$

Date: 1989

Affiliated/Future Projects: None

Technology: Preconcentrating wastewater streams and membrane processes; drying systems feature modules with membranes permeable to vapor but not to air.

Reference: IEA CADDET

\begin{tabular}{|c|c|}
\hline $\begin{array}{l}\text { Title: Cooling System for Fruit and Vegetable } \\
\text { Storage Plant }\end{array}$ & Project Type: Study/demonstration \\
\hline Organization: Kirk Produce, Inc., California & Date: 1986 to 1987 \\
\hline End-use Sector: Industry (cooling system) & Affiliated/Future Projects: None \\
\hline $\begin{array}{l}\text { Description: Study and demonstration of a new } \\
\text { cooling system that incorporates energy } \\
\text { efficiency and saves floor space. }\end{array}$ & $\begin{array}{l}\text { Technology: Cooling produce before packing it } \\
\text { to reduce fragility and bruising while } \\
\text { maintaining proper relative humidity in a } \\
\text { microprocessor. }\end{array}$ \\
\hline $\begin{array}{l}\text { Results: This project resulted in a } 50 \% \\
\text { reduction in refrigeration costs, enhanced market } \\
\text { life of produce, increased profits from produce. } \\
\text { The system has a 14-year payback. }\end{array}$ & Reference: IEA CADDET \\
\hline
\end{tabular}




\begin{tabular}{|c|c|}
\hline Title: High-Temperature Materials Laboratory & Project Type: $R \& D$ \\
\hline Organization: U.S. Department of Energy & Date: 1987 ; continuing \\
\hline End-use Sector: Industry & Affiliated/Future Projects: None \\
\hline $\begin{array}{l}\text { Description: Laboratory serves as a focal point } \\
\text { for multidisciplinary research on new ceramics } \\
\text { and metal alloys that show potential for high- } \\
\text { temperature applications. }\end{array}$ & Technology: N/A \\
\hline $\begin{array}{l}\text { Results: During the first year-and-a-half of } \\
\text { operation, } 27 \text { universities, } 24 \text { industrial } \\
\text { companies, and } 3 \text { government facilities signed } \\
\text { agreements to use the facility. }\end{array}$ & $\begin{array}{l}\text { Reference: A Compendium of Energy } \\
\text { Conservation Success Stories } 90\end{array}$ \\
\hline
\end{tabular}

\begin{tabular}{|c|c|}
\hline Title: Gel Casting & Project Type: R\&D \\
\hline Organization: U.S. Department of Energy & Date: N/A \\
\hline $\begin{array}{l}\text { End-use Sector: Industry (ceramic } \\
\text { manufacturers) }\end{array}$ & Affiliated/Future Projects: None \\
\hline $\begin{array}{l}\text { Description: A new method of gel casting } \\
\text { ceramic powders is fast and economical and } \\
\text { allows product dimensions to be controlled } \\
\text { closely. }\end{array}$ & $\begin{array}{l}\text { Technology: Gel casting separates the mold- } \\
\text { filling and setting operations and uses a water- } \\
\text { based vehicle. }\end{array}$ \\
\hline $\begin{array}{l}\text { Results: Tensile and other alumina oxide } \\
\text { ceramic specimens were produced successfully } \\
\text { using this method in the laboratory. }\end{array}$ & $\begin{array}{l}\text { Reference: A Compendium of Energy } \\
\text { Conservation Success Stories } 90\end{array}$ \\
\hline
\end{tabular}




\begin{tabular}{|c|c|}
\hline $\begin{array}{l}\text { Title: Microwave Processing of Ceramic } \\
\text { Materials }\end{array}$ & Project Type: R\&D \\
\hline Organization: U.S. Department of Energy & Date: N/A \\
\hline $\begin{array}{l}\text { End-use Sector: Industry (ceramics } \\
\text { manufacturers) }\end{array}$ & Affiliated/Future Projects: None \\
\hline $\begin{array}{l}\text { Description: Large pieces of high-purity } \\
\text { alumina can be heated uniformly and sintered in } \\
\text { microwave ovens quickly and at lower } \\
\text { temperatures than when using conventional } \\
\text { infrared methods. }\end{array}$ & $\begin{array}{l}\text { Technology: Microwave oven uses a frequency } \\
\text { of } 28 \text { ghz. }\end{array}$ \\
\hline $\begin{array}{l}\text { Results: The material densified more rapidly, } \\
\text { and the activation energy required was much } \\
\text { lower than that required in current processing } \\
\text { techniques. }\end{array}$ & $\begin{array}{l}\text { Reference: A Compendium of Energy } \\
\text { Conservation Success Stories } 90\end{array}$ \\
\hline
\end{tabular}

\begin{tabular}{|c|c|}
\hline Title: Hyperfiltration of Food & Project Type: R\&D \\
\hline Organization: U.S. Department of Energy & Date: N/A \\
\hline End-use Sector: Industry (food processing) & Affiliated/Future Projects: None \\
\hline $\begin{array}{l}\text { Description: Thin-film composites that can } \\
\text { withstand higher temperatures, operate within a } \\
\text { wider pH range, and have increased resistance } \\
\text { to biological degradation can be used to } \\
\text { concentrate fruit and vegetable juices. }\end{array}$ & $\begin{array}{l}\text { Technology: The membranes were tested in } \\
\text { selected high-temperature food-processing } \\
\text { streams to characterize membrane performance } \\
\text { as a function of time. }\end{array}$ \\
\hline $\begin{array}{l}\text { Results: A prototype unit for concentrating } \\
\text { tomato juice was built and tested successfully. }\end{array}$ & $\begin{array}{l}\text { Reference: A Compendium of Energy } \\
\text { Conservation Success Stories } 90\end{array}$ \\
\hline
\end{tabular}




\begin{tabular}{l|l|}
\hline Title: PET Bottle Separator & Project Type: Study/demonstration \\
\hdashline Organization: U.S. Department of Energy & Date: N/A; continuing \\
Procedyne Corporation & Affiliated/Future Projects: None \\
\hdashline End-use Sector: Industry & Technology: N/A \\
\hdashline Description: A combination of separation \\
processes can sort bottles and cans by those \\
made of PET (polyethylene terephthalate), high- \\
density polyethylene, or aluminum.
\end{tabular}

\begin{tabular}{l:l}
\hline Title: Dew-Point Hygrometer & Project Type: Study/demonstration \\
\hdashline Organization: U.S. Department of Energy with & Date: N/A \\
Trans-Met Engineering & \\
\hdashline End-use Sector: Industry & Affiliated/Future Projects: None \\
\hdashline Description: New hygrometer withstands dust \\
and grease, temperatures up to $500^{\circ} \mathrm{F}$, and \\
relative humidities between $50 \%$ and $100 \%$ to \\
monitor humidity and temperature of exhaust \\
gases in drying operations.
\end{tabular}




\begin{tabular}{|c|c|}
\hline Title: Optical Humidity Sensor & Project Type: Study/demonstration \\
\hline $\begin{array}{l}\text { Organization: U.S. Department of Energy with } \\
\text { Spectral Sciences and Pacer Systems }\end{array}$ & Date: N/A \\
\hline End-use Sector: Industry & Affiliated/Future Projects: None \\
\hline $\begin{array}{l}\text { Description: New hygrometer measures the } \\
\text { absorption of ultraviolet light (a property of } \\
\text { water vapor in air or process gas) to determine } \\
\text { humidity in various industrial processes. }\end{array}$ & $\begin{array}{l}\text { Technology: Optical elements of the sensor do } \\
\text { not directly contact the medium, protecting the } \\
\text { sensor from contamination. }\end{array}$ \\
\hline $\begin{array}{l}\text { Results: Hygrometer is commercialized and } \\
\text { installed in several pulp and paper mills. } \\
\text { Energy savings are projected to be } 217.3 \text { trillion } \\
\text { Btu in } 2010 \text {. }\end{array}$ & $\begin{array}{l}\text { Reference: A Compendium of Energy } \\
\text { Conservation Success Stories } 90\end{array}$ \\
\hline
\end{tabular}

\begin{tabular}{|c|c|}
\hline Title: Rapid Solidification of Metals & Project Type: R\&D \\
\hline Organization: U.S. Department of Energy & Date: N/A \\
\hline End-use Sector: Industry & Affiliated/Future Projects: None \\
\hline $\begin{array}{l}\text { Description: A gas stream impacts and breaks } \\
\text { up a stream of molten metal into fine droplets to } \\
\text { solidify rapidly and, thus, strengthen metal } \\
\text { alloys. }\end{array}$ & $\begin{array}{l}\text { Technology: The repetitive process produces a } \\
\text { high concentration of atomic vacancies, which } \\
\text { would normally anneal out of the alloy at high } \\
\text { temperatures. The dissolved gas entrapped } \\
\text { during rapid solidification stabilizes the } \\
\text { vacancies in clusters. }\end{array}$ \\
\hline $\begin{array}{l}\text { Results: Austenitic stainless steels processed } \\
\text { this way increase their service lives } 60 \text {-fold. The } \\
\text { technique could also be used to process iron, } \\
\text { aluminum, nickel, and other metal alloys. }\end{array}$ & $\begin{array}{l}\text { Reference: A Compendium of Energy } \\
\text { Conservation Success Stories } 90\end{array}$ \\
\hline
\end{tabular}

\begin{tabular}{|c|c|}
\hline $\begin{array}{l}\text { Title: A Computerized Tribology Information } \\
\text { System (ACTIS) }\end{array}$ & Project Type: R\&D \\
\hline $\begin{array}{l}\text { Organization: U.S. Department of Energy with } \\
\text { the National Institute of Standards and } \\
\text { Technology }\end{array}$ & Date: N/A \\
\hline End-use Sector: Industry & Affiliated/Future Projects: None \\
\hline $\begin{array}{l}\text { Description: ACTIS is a data base that will } \\
\text { provide a central location for information on } \\
\text { tribology research and products. }\end{array}$ & $\begin{array}{l}\text { Technology: Software is being developed to } \\
\text { work on IBM (or compatible) personal } \\
\text { computers and will be commercially available to } \\
\text { the tribology community soon. }\end{array}$ \\
\hline Results: N/A & $\begin{array}{l}\text { Reference: A Compendium of Energy } \\
\text { Conservation Success Stories } 90\end{array}$ \\
\hline
\end{tabular}




\begin{tabular}{|c|c|}
\hline $\begin{array}{l}\text { Title: Raccoon Mountain Pumped-Storage } \\
\text { Plant }\end{array}$ & Project Type: Study/demonstration \\
\hline Organization: Tennessee Valley Authority & Date: 1970 to 1979 \\
\hline End-use Sector: Utility & Affiliated/Future Projects: None \\
\hline $\begin{array}{l}\text { Description: Study to build a facility that } \\
\text { would best meet the growing power demands of } \\
\text { the Tennessee Valley region. }\end{array}$ & $\begin{array}{l}\text { Technology: A pumped-storage plant that pro- } \\
\text { duces energy at a high rate during high demand, } \\
\text { and recharges when demand is low to ready } \\
\text { itself for the next high demand period. Total } \\
\text { cost: } \$ 287 \text { million. }\end{array}$ \\
\hline $\begin{array}{l}\text { Results: Replaces more expensive forms of } \\
\text { power generation at peak load times; provides } \\
\text { quick start-up emergency power generation } \\
\text { capability. }\end{array}$ & Reference: IEA CADDET \\
\hline
\end{tabular}

\begin{tabular}{|c|c|}
\hline Title: Electric Vehicle Site Operations Program & Project Type: R\&D \\
\hline Organization: U.S. Department of Energy & Date: 1976; continuing \\
\hline End-use Sector: Transportation & Affiliated/Future Projects: None \\
\hline $\begin{array}{l}\text { Description: The program evaluates the } \\
\text { effectiveness of technological advances in } \\
\text { electric vehicle research. }\end{array}$ & $\begin{array}{l}\text { Technology: The program has evaluated more } \\
\text { than } 20 \text { electric vehicles and } 16 \text { product } \\
\text { improvements. }\end{array}$ \\
\hline $\begin{array}{l}\text { Results: Research objectives are being met and } \\
\text { often exceeded. Electric vehicle energy } \\
\text { consumption was reduced by more than } 50 \% \text {; } \\
\text { reliability levels increased by } 78 \% \text {; maintenance } \\
\text { costs were reduced by } 60 \% \text {; and overall life- } \\
\text { cycle costs were reduced by } 67 \% \text {. }\end{array}$ & $\begin{array}{l}\text { Reference: A compendium of Energy } \\
\text { Conservation Success Stories } 90\end{array}$ \\
\hline
\end{tabular}




\begin{tabular}{|c|c|}
\hline $\begin{array}{l}\text { Title: Dual-Shaft, Advanced Alternating- } \\
\text { Current Propulsion System }\end{array}$ & Project Type: R\&D \\
\hline $\begin{array}{l}\text { Organization: U.S. Department of Energy, } \\
\text { Eaton Corporation, Eagle-Picher Industries, } \\
\text { ASC, Inc. }\end{array}$ & Date: N/A \\
\hline End-use Sector: Transportation & Affiliated/Future Projects: None \\
\hline $\begin{array}{l}\text { Description: An advanced propulsion system } \\
\text { will drive an electric lightweight van. }\end{array}$ & $\begin{array}{l}\text { Technology: An industrial research team } \\
\text { designed, built, and tested three advanced, } \\
\text { proof-of-concept propulsion systems that were } \\
\text { installed in Chrysler T-115 minivans. Major } \\
\text { emphasis was to advance existing battery and } \\
\text { power train technologies through integrated } \\
\text { development of a nickel/iron battery, an } \\
\text { alternating-current motor and controls, and an } \\
\text { automatic two-speed transaxle. }\end{array}$ \\
\hline $\begin{array}{l}\text { Results: Vehicle performance goals for } \\
\text { acceleration, gradability, top speed, range, and } \\
\text { energy efficiency were reached or surpassed. }\end{array}$ & $\begin{array}{l}\text { Reference: A Compendium of Energy } \\
\text { Conservation Success Stories } 90\end{array}$ \\
\hline
\end{tabular}

\begin{tabular}{|c|c|}
\hline $\begin{array}{l}\text { Title: Gel-Cell, Lead-Acid Battery-powered } \\
\text { Electric Vehicles }\end{array}$ & Project Type: R\&D \\
\hline Organization: U.S. Department of Energy & Date: 1982 ; continuing \\
\hline End-use Sector: Transportation & Affiliated/Future Projects: None \\
\hline $\begin{array}{l}\text { Description: Gel-cell batteries reduce } \\
\text { maintenance requirements and improve safety } \\
\text { conditions and efficiency levels. }\end{array}$ & $\begin{array}{l}\text { Technology: DOE, along with universities, the } \\
\text { private sector, and other federal agencies, } \\
\text { developed technology to reduce maintenance } \\
\text { costs. }\end{array}$ \\
\hline $\begin{array}{l}\text { Results: The batteries reduced vehicle } \\
\text { maintenance costs by } 50 \% \text {, increased energy } \\
\text { efficiency by more than } 50 \% \text {, and increased } \\
\text { operating safety. }\end{array}$ & $\begin{array}{l}\text { Reference: A Compendium of Energy } \\
\text { Conservation Success Stories } 90\end{array}$ \\
\hline
\end{tabular}




\begin{tabular}{l:l}
\hline Title: Engine Materials & Project Type: $R \& D$ \\
\hdashline Organization: IEA (participants are United \\
States and two others)
\end{tabular}

\begin{tabular}{|c|c|}
\hline Title: Federal Methanol Fleet & Project Type: Study/demonstration \\
\hline Organization: Oak Ridge National Laboratory & Date: 1985 to 1988 \\
\hline End-use Sector: Transportation & Affiliated/Future Projects: None \\
\hline $\begin{array}{l}\text { Description: Demonstration of the level of } \\
\text { maturity of methanol fuel vehicle technology. }\end{array}$ & $\begin{array}{l}\text { Technology: Thirty-nine vehicles make up the } \\
\text { fleet: } 20 \text { methanol powered, } 4 \text { vehicle models. } \\
\text { Some methanol engines utilize high- } \\
\text { compression-ratio pistons, some have } \\
\text { turbochargers. Vehicles were operated on fuel } \\
\text { methanol (M85). }\end{array}$ \\
\hline $\begin{array}{l}\text { Results: Lower flammability = greater safety, } \\
\text { higher octane yields greater power. Energy } \\
\text { efficiency is equal between methanol and petrol } \\
\text { vehicles; methanol cars have lower ease-of- } \\
\text { starting rating. }\end{array}$ & Reference: IEA CADDET \\
\hline
\end{tabular}




\begin{tabular}{|c|c|}
\hline Title: Federal Methanol Fleet & Project Type: Study/demonstration \\
\hline Organization: U.S. Department of Energy & Date: 1985 to 1989 ; continuing \\
\hline End-use Sector: Transportation & Affiliated/Future Projects: None \\
\hline $\begin{array}{l}\text { Description: Demonstrates the technological } \\
\text { feasibility of methanol-fueled cars. Fleet } \\
\text { contains } 20 \text { methanol-fueled and } 19 \text { gasoline- } \\
\text { fueled cars. }\end{array}$ & $\begin{array}{l}\text { Technology: Retrofitted gasoline-fueled cars. } \\
\text { Fuel mixture is } 85 \% \text { methanol, } 15 \% \text { unleaded } \\
\text { gasoline. }\end{array}$ \\
\hline $\begin{array}{l}\text { Results: Performance was virtually trouble- } \\
\text { free, although methanol-fueled cars consumed } \\
\text { slightly more fuel than gasoline-fueled cars } \\
\text { because of different driving cycles. Maintenance } \\
\text { statistics compare well. Methanol is a viable } \\
\text { substitute for imported petroleum products. }\end{array}$ & $\begin{array}{l}\text { Reference: A Compendium of Energy } \\
\text { Conservation Success Stories } 90\end{array}$ \\
\hline
\end{tabular}

\begin{tabular}{|c|c|}
\hline Title: 1989 Methanol Marathon & Project Type: Study/demonstration \\
\hline $\begin{array}{l}\text { Organization: U.S. Department of Energy with } \\
\text { Society of Automotive Engineers }\end{array}$ & Date: 1989 \\
\hline End-use Sector: Transportation & Affiliated/Future Projects: None \\
\hline $\begin{array}{l}\text { Description: Competition among college } \\
\text { students to engineer and race methanol-fueled } \\
\text { cars. The competition included static tests and a } \\
1100 \text {-mile (1770-kilometer) road rally. }\end{array}$ & $\begin{array}{l}\text { Technology: Chevrolet Corsicas were } \\
\text { retrofitted to run on a blend of } 85 \% \text { methanol } \\
\text { and } 15 \% \text { gasoline. }\end{array}$ \\
\hline $\begin{array}{l}\text { Results: Results: The winning car averaged } \\
36.7 \text { miles per gallon ( } 59 \text { kilometers per } \\
3.8 \text { liters). More than } 200 \text { students learned } \\
\text { about alternative transportation fuels. }\end{array}$ & $\begin{array}{l}\text { Reference: A Compendium of Energy } \\
\text { Conservation Success Stories } 90\end{array}$ \\
\hline
\end{tabular}

\begin{tabular}{|c|c|}
\hline Title: High-Temperature Liquid Lubricants & Project Type: R\&D \\
\hline Organization: U.S. Department of Energy & Date: N/A, continuing \\
\hline End-use Sector: Transportation & Affiliated/Future Projects: None \\
\hline $\begin{array}{l}\text { Description: New synthetic oils being } \\
\text { developed will allow engines to operate in } \\
\text { temperature ranges three times those of } \\
\text { conventional oils. }\end{array}$ & Technology: N/A \\
\hline $\begin{array}{l}\text { Results: New lubricants will decompose oil } \\
\text { cleanly, form less soot, emit fewer particulates, } \\
\text { and reduce engine wear. }\end{array}$ & $\begin{array}{l}\text { Reference: A Compendium of Energy } \\
\text { Conservation Success Stories } 90\end{array}$ \\
\hline
\end{tabular}


Title: Spark Plug Instrumented with Fiber Optics

Organization: U.S. Department of Energy with Chrysler Corporation

End-use Sector: Transportation

Description: Special spark plug installed in standard automobile engines can observe flame propagation in the combustion chamber.

Subsequent measurements will help engineers improve combustion efficiency.

Results: Flame development measurements showed the flame to be more asymmetric than expected.

\section{Project Type: R\&D}

Date: 1987; continuing

Affiliated/Future Projects: None

Technology: N/A

Reference: A Compendium of Energy

Conservation Success Stories 90

\begin{tabular}{|c|c|}
\hline Title: Advanced Inverter Technology & Project Type: R\&D \\
\hline Organization: U.S. Department of Energy & Date: N/A \\
\hline End-use Sector: Transportation & Affiliated/Future Projects: None \\
\hline $\begin{array}{l}\text { Description: The new inverter to be used in } \\
\text { electric vehicles is smaller and weighs less than } \\
\text { existing inverters. }\end{array}$ & $\begin{array}{l}\text { Technology: A metal-oxide semiconductor- } \\
\text { controlled thyristor power switch and high- } \\
\text { voltage multilayer capacitors give the inverter } \\
\text { greater power efficiency and better thermal } \\
\text { management while reducing capacitor volume } \\
\text { and heat loss. }\end{array}$ \\
\hline $\begin{array}{l}\text { Results: Development of an inverter and } \\
\text { control system for a diesel/electric drive motor } \\
\text { for the radiator cooling fans on commercial } \\
\text { diesel/electric locomotives. }\end{array}$ & $\begin{array}{l}\text { Reference: A Compendium of Energy } \\
\text { Conservation Success Stories } 90\end{array}$ \\
\hline
\end{tabular}




\begin{tabular}{|c|c|}
\hline Title: Battery Combustion-Attenuation Material & Project Type: $R \& D$ \\
\hline Organization: U.S. Department of Energy & Date: N/A \\
\hline End-use Sector: Transportation & Affiliated/Future Projects: None \\
\hline $\begin{array}{l}\text { Description: The material fills the headspace } \\
\text { of basic and electrolyte batteries, preventing the } \\
\text { battery cases from rupturing if gases within the } \\
\text { battery cells should ignite during charging or } \\
\text { operation of an electric vehicle. }\end{array}$ & $\begin{array}{l}\text { Technology: The material was tested with } \\
\text { nickel-iron battery modules. }\end{array}$ \\
\hline $\begin{array}{l}\text { Results: The material clearly reduced the level } \\
\text { of risk and was patented and incorporated into } \\
\text { the nickel-iron battery packs being designed for } \\
\text { dual-shaft electric propulsion systems. }\end{array}$ & $\begin{array}{l}\text { Reference: A Compendium of Energy } \\
\text { Conservation Success Stories } 90\end{array}$ \\
\hline
\end{tabular}

Title: A Computerized Tribology Information System (ACTIS)

Organization: U.S. Department of Energy with the National Institute of Standards and Technology

End-use Sector: Transportation; industry

Description: ACTIS is a data base that will provide a central location for information on tribology research and products.

\section{Project Type: R\&D}

Date: N/A

Affiliated/Future Projects: None

Technology: Software is being developed to work on IBM (or compatible) personal computers and will be commercially available to the tribology community soon.

Reference: A Compendium of Energy

Conservation Success Stories 90
Title: Program for the Energy Analysis of Residences (PEAR)

Organization: U.S. Department of Energy

End-use Sector: Residential building

Description: Computer program enables builders and designers to estimate the annual energy use of new houses equipped with typical conservation measures.

Results: N/A

\section{Project Type: Technology transfer}

Date: N/A

\section{Affiliated/Future Projects: None}

Technology: Using this program, builders can choose home insulation levels, window types and glazing layers, infiltration levels, amount of thermal mass, and equipment efficiency.

Reference: A Compendium of Energy Conservation Success Stories 90 


\begin{tabular}{|c|c|}
\hline $\begin{array}{l}\text { Title: Computer-based Conservation Standards } \\
\text { for New Federal Residential Buildings }\end{array}$ & Project Type: Standards and codes \\
\hline Organization: U.S. Department of Energy & Date: N/A \\
\hline End-use Sector: Residential building & Affiliated/Future Projects: None \\
\hline $\begin{array}{l}\text { Description: Using this software program, } \\
\text { builders can submit the most cost-effective } \\
\text { combination of energy conservation measures } \\
\text { when bidding on federal housing projects. }\end{array}$ & $\begin{array}{l}\text { Technology: The user-friendly program } \\
\text { calculates the most cost-effective combination } \\
\text { of conservation measures and checks } \\
\text { compliance with standards for federal housing } \\
\text { projects. }\end{array}$ \\
\hline Results: N/A & $\begin{array}{l}\text { Reference: A Compendium of Energy } \\
\text { Conservation Success Stories } 90\end{array}$ \\
\hline
\end{tabular}

\begin{tabular}{|c|c|}
\hline Title: Building Foundation Design Manual & Project Type: Education/information \\
\hline Organization: U.S. Department of Energy & Date: 1986 \\
\hline End-use Sector: Residential building & Affiliated/Future Projects: None \\
\hline $\begin{array}{l}\text { Description: The manual contains information } \\
\text { on the cost-effectiveness of foundation } \\
\text { insulation in most U.S. climates. }\end{array}$ & $\begin{array}{l}\text { Technology: The manual covers energy- } \\
\text { efficient building foundation design and } \\
\text { recommends practices for structure, drainage, } \\
\text { waterproofing, radon mitigation, and termite } \\
\text { control. }\end{array}$ \\
\hline $\begin{array}{l}\text { Results: National savings derived from } \\
\text { adopting designs recommended in the manual } \\
\text { could approach } 0.5 \text { quad annually. }\end{array}$ & $\begin{array}{l}\text { Reference: A Compendium of Energy } \\
\text { Conservation Success Stories } 90\end{array}$ \\
\hline
\end{tabular}




\begin{tabular}{|c|c|}
\hline $\begin{array}{l}\text { Title: Single-Family Retrofit Research and } \\
\text { Technology Transfer Program }\end{array}$ & Project Type: Technology transfer \\
\hline Organization: U.S. Department of Energy & Date: N/A; continuing \\
\hline End-use Sector: Residential building & Affiliated/Future Projects: None \\
\hline $\begin{array}{l}\text { Description: The program provides information } \\
\text { on the latest research in residential energy } \\
\text { conservation. }\end{array}$ & $\begin{array}{l}\text { Technology: The program leverages state and } \\
\text { private resources to improve conservation } \\
\text { programs, provides better technical training of } \\
\text { weatherization providers, and increases research } \\
\text { activities in the field and in national } \\
\text { laboratories. }\end{array}$ \\
\hline $\begin{array}{l}\text { Results: The program improved the energy } \\
\text { savings and cost-effectiveness of } 27 \text { state } \\
\text { weatherization programs and provided training } \\
\text { to } 1,600 \text { energy auditors and private heating } \\
\text { contractors in new efficiency technologies. } \\
\text { More than } 20,000 \text { homes were retrofitted } \\
\text { through this program. }\end{array}$ & $\begin{array}{l}\text { Reference: A Compendium of Energy } \\
\text { Conservation Success Stories } 90\end{array}$ \\
\hline
\end{tabular}

\begin{tabular}{|l:l|}
\hline Title: High-Efficiency Refrigerator Compressor & Project Type: R\&D \\
\hdashline Organization: U.S. Department of Energy & Date: N/A \\
\hdashline End-use Sector: Residential building & Affiliated/Future Projects: None \\
\hdashline $\begin{array}{l}\text { Description: The development of a more } \\
\text { efficient refrigerator compressor has led to a }\end{array}$ & Technology: Design changes include the \\
more advanced compressor. & refrigerator motor and suction muffler. \\
\hdashline $\begin{array}{l}\text { Results: First redesign achieved a 44\% } \\
\text { improvement over conventional compressors. } \\
\text { Advanced compressor is rated at more than } \\
5 \text { Btu (5.3 joules) per watt-hour. Energy }\end{array}$ \\
savings are estimated at about 0.21 quad per \\
year by 2010.
\end{tabular}




\begin{tabular}{|c|c|}
\hline Title: Appliance Efficiency Test Procedures & Project Type: Certification \\
\hline Organization: U.S. Department of Energy & Date: 1975 ; continuing \\
\hline End-use Sector: Residential building & Affiliated/Future Projects: None \\
\hline $\begin{array}{l}\text { Description: Procedures developed are used to } \\
\text { test and label energy consumption and } \\
\text { efficiency of } 12 \text { categories of major household } \\
\text { appliances. }\end{array}$ & Technology: N/A \\
\hline $\begin{array}{l}\text { Results: Four national trade and professional } \\
\text { associations adopted procedures. Consumers are } \\
\text { rejecting less efficient appliances; and } \\
\text { manufacturers are producing appliances that are } \\
\text { up to } 50 \% \text { more energy efficient than older } \\
\text { models. }\end{array}$ & $\begin{array}{l}\text { Reference: A Compendium of Energy } \\
\text { Conservation Success Stories } 90\end{array}$ \\
\hline
\end{tabular}

\begin{tabular}{|c|c|}
\hline Title: Ground-coupled Heat Pumps & Project Type: R\&D \\
\hline Organization: U.S. Department of Energy & Date: N/A \\
\hline End-use Sector: Residential building & Affiliated/Future Projects: None \\
\hline $\begin{array}{l}\text { Description: A ground-coupled heat pump was } \\
\text { developed that was more cost-effective and } \\
\text { more energy efficient. }\end{array}$ & Technology: Two experimental prototypes \\
\hline $\begin{array}{l}\text { Results: The advanced design reduced the } \\
\text { payback period from } 6 \text { to } 10 \text { years to } 3 \text { to } \\
5 \text { years and will save about } 0.32 \text { quad of energy } \\
\text { by } 2010 \text {. }\end{array}$ & $\begin{array}{l}\text { Reference: A Compendium of Energy } \\
\text { Conservation Success Stories } 90\end{array}$ \\
\hline
\end{tabular}

\begin{tabular}{|c|c|}
\hline Title: Flame-Retention Oil Burner & Project Type: Education/information \\
\hline Organization: U.S. Department of Energy & Date: Late 1970 s, N/A \\
\hline End-use Sector: Residential building & Affiliated/Future Projects: None \\
\hline $\begin{array}{l}\text { Description: The energy conservation benefit } \\
\text { of the flame-retention-head oil burner was } \\
\text { established and communicated to the public in a } \\
\text { consumer-oriented booklet. }\end{array}$ & Technology: Oil burner \\
\hline $\begin{array}{l}\text { Results: The number of burners in use } \\
\text { increased from } 100,000 \text { in } 1979 \text { to more than } \\
4.2 \text { million in } 1989, \text { saving about } 71 \text { trillion } \\
\text { Btus ( } 75 \text { trillion joules) annually. }\end{array}$ & $\begin{array}{l}\text { Reference: A Compendium of Energy } \\
\text { Conservation Success Stories } 90\end{array}$ \\
\hline
\end{tabular}




\begin{tabular}{|c|c|}
\hline $\begin{array}{l}\text { Title: Radiant Barriers for Single-Family } \\
\text { Housing }\end{array}$ & Project Type: Study/demonstration \\
\hline $\begin{array}{l}\text { Organization: U.S. Department of Energy and } \\
\text { Tennessee Valley Authority }\end{array}$ & Date: N/A \\
\hline End-use Sector: Residential building & Affiliated/Future Projects: None \\
\hline $\begin{array}{l}\text { Description: A low-cost, easily installed } \\
\text { aluminum foil product promises significant } \\
\text { reductions in attic heat transfer. }\end{array}$ & $\begin{array}{l}\text { Technology: Product has two reflective } \\
\text { surfaces. }\end{array}$ \\
\hline $\begin{array}{l}\text { Results: Cooling energy requirements were } \\
\text { reduced by } 17 \% \text { and heating energy } \\
\text { requirements by } 9 \% \text {, yielding a payback in } \\
\text { energy savings of two years if installed by } \\
\text { homeowner. }\end{array}$ & $\begin{array}{l}\text { Reference: A Compendium of Energy } \\
\text { Conservation Success Stories } 90\end{array}$ \\
\hline
\end{tabular}

\begin{tabular}{|c|c|}
\hline $\begin{array}{l}\text { Title: New Image and Lower Energy Bills in } \\
\text { Manchester Inner-City Neighborhood }\end{array}$ & Project Type: Study/demonstration \\
\hline $\begin{array}{l}\text { Organization: Carnegie-Mellon University } \\
\text { (Center for Building Performance and } \\
\text { Diagnostics) }\end{array}$ & Date: Late 1970 s to 1983 \\
\hline End-use Sector: Residential building & Affiliated/Future Projects: None \\
\hline $\begin{array}{l}\text { Description: Project demonstrating and } \\
\text { promoting benefits of inner-city revitalization } \\
\text { using energy-efficient retrofits for existing } \\
\text { housing units and energy-conscious new } \\
\text { construction. }\end{array}$ & $\begin{array}{l}\text { Technology: Homes clustered to reduce } \\
\text { exterior exposure; higher thermal quality of } \\
\text { walls, roofs and windows; homes oriented so } \\
\text { living area can take advantage of sun; careful } \\
\text { insulation; wind barrier continuity provided by } \\
\text { wrapping house in vapor-porous windbreaker. }\end{array}$ \\
\hline $\begin{array}{l}\text { Results: The project achieved a } 75 \% \text { to } 80 \% \\
\text { energy savings over detached standard- } \\
\text { construction homes, reduced fuel subsidies, and } \\
\text { renewed the use of an urban infrastructure. }\end{array}$ & Reference: IEA CADDET \\
\hline
\end{tabular}




\begin{tabular}{|c|c|}
\hline $\begin{array}{l}\text { Title: Super-insulation, Thermal Storage and } \\
\text { Passive Solar Gain at Brookhaven House }\end{array}$ & Project Type: Study/demonstration \\
\hline $\begin{array}{l}\text { Organization: Brookhaven National Lab, New } \\
\text { York }\end{array}$ & Date: 1990 \\
\hline End-use Sector: Residential building & Affiliated/Future Projects: None \\
\hline $\begin{array}{l}\text { Description: Study and demonstration to } \\
\text { provide technical data about how to use thermal } \\
\text { storage in the building structure as an acceptable } \\
\text { option for reducing the costs and energy for } \\
\text { space conditioning of small buildings. }\end{array}$ & $\begin{array}{l}\text { Technology: Brookhaven house incorporates } \\
\text { natural thermal storage of common building } \\
\text { materials with passive solar strategies in a } \\
\text { tightly constructed, super-insulated house. }\end{array}$ \\
\hline $\begin{array}{l}\text { Results: Auxiliary heating was reduced } 75 \% \\
\text { using standard building techniques and common } \\
\text { construction materials. }\end{array}$ & Reference: IEA CADDET \\
\hline
\end{tabular}

\begin{tabular}{|l|l|}
\hline Title: Low-Mass, Purgeable Boiler & Project Type: R\&D \\
\hdashline Organization: U.S. Department of Energy with \\
Energy Kinetics Corporation
\end{tabular}


Title: Low-Cost Analyzer for Oil-Burner Flames

Organization: U.S. Department of Energy with Canadian Mortgage and Housing Corporation

End-use Sector: Residential building

Description: An optical flame monitor incorporated into a furnace that shows when combustion air is set for the highest efficiency and indicates when the burner needs adjustment or servicing.

Results: N/A

\section{Project Type: R\&D}

Date: 1988; continuing

Affiliated/Future Projects: None

Technology: Improves residential oil-fired furnace energy performance using optical detectors and common electronic devices.

Reference: A Compendium of Energy

Conservation Success Stories 90

\begin{tabular}{|c|c|}
\hline Title: Supermarket Refrigeration Systems & Project Type: R\&D \\
\hline Organization: U.S. Department of Energy & Date: N/A \\
\hline End-use Sector: Commercial building & Affiliated/Future Projects: None \\
\hline $\begin{array}{l}\text { Description: An advanced system offers } \\
\text { multiple, unequal, parallel compressors for } \\
\text { supermarket refrigeration. }\end{array}$ & $\begin{array}{l}\text { Technology: System features microprocessor } \\
\text { controls. }\end{array}$ \\
\hline $\begin{array}{l}\text { Results: System reduces energy consumed by } \\
\text { more than } 40 \% \text {. Primary energy savings are } \\
\text { expected to be between } 0.25 \text { and } 0.37 \text { quad } \\
\text { annually by } 2000 \text {. }\end{array}$ & $\begin{array}{l}\text { Reference: A Compendium of Energy } \\
\text { Conservation Success Stories } 90\end{array}$ \\
\hline
\end{tabular}




\begin{tabular}{|c|c|}
\hline $\begin{array}{l}\text { Title: Energy Management Program at the } \\
\text { World Bank }\end{array}$ & Project Type: Study/demonstration \\
\hline $\begin{array}{l}\text { Organization: International Energy Agency } \\
\text { (World Bank, U.S.) }\end{array}$ & Date: 1987 to 1990 \\
\hline End-use Sector: Commercial building & Affiliated/Future Projects: None \\
\hline $\begin{array}{l}\text { Description: Energy management program at } \\
\text { the World Bank to improve the operating } \\
\text { efficiency of headquarters building. }\end{array}$ & $\begin{array}{l}\text { Technology: } \$ 1.5 \text { million in capital projects: } \\
\text { computerized lighting control system, expansion } \\
\text { of computerized energy management system, } \\
\text { installation of return air fan and balancing } \\
\text { dampers, installation of variable speed motor } \\
\text { drives on handling units, installation of } \\
\text { supplemental air conditioning system, } \\
\text { interconnection of existing boiler plants, } \\
\text { installation of high-efficiency fluorescent lamp } \\
\text { ballasts, installation of evaporative cooling } \\
\text { system, installation of gas-fired hot water } \\
\text { heaters. }\end{array}$ \\
\hline $\begin{array}{l}\text { Results: During FY } 1987, \$ 1 \text { million saved in } \\
\text { energy costs, a } 20 \% \text { reduction in the energy } \\
\text { budget. }\end{array}$ & Reference: IEA CADDET \\
\hline
\end{tabular}

\begin{tabular}{|l:l|}
\hline $\begin{array}{l}\text { Title: A Desiccant-Based Cooling System for } \\
\text { Supermarkets }\end{array}$ & Project Type: Study/demonstration \\
\hdashline $\begin{array}{l}\text { Organization: HE Butt Grocery Company, } \\
\text { Texas }\end{array}$ & Date: 1987 \\
\hdashline End-use Sector: Commercial building & Affiliated/Future Projects: None \\
\hdashline $\begin{array}{l}\text { Description: Study to find alternative ways of } \\
\text { cooling supermarkets to lower consumer costs. }\end{array}$ & $\begin{array}{l}\text { Technology: A gas-fired, desiccant air } \\
\text { conditioning system for supermarkets, which } \\
\text { integrates gas humidification with electric air } \\
\text { conditioning. Cost savings at one location was }\end{array}$ \\
\hdashline $\begin{array}{l}\text { Results: Savings through decreased energy } \\
\text { consumption and power demand; energy costs } \\
\text { reduced 7\% to 10\% for air conditioning and } \\
\text { refrigeration; improved indoor climate for } \\
\text { shoppers; more attractive refrigerated products. }\end{array}$ & \\
\hline
\end{tabular}




\begin{tabular}{|c|c|}
\hline $\begin{array}{l}\text { Title: Energy Management at the Dubal/Beck } \\
\text { Office Building }\end{array}$ & Project Type: Study/demonstration \\
\hline $\begin{array}{l}\text { Organization: International Energy Agency } \\
\text { (Dubal, Beck, Harris and Assoc., Oregon) }\end{array}$ & Date: 1988 \\
\hline End-use Sector: Commercial building & Affiliated/Future Projects: None \\
\hline $\begin{array}{l}\text { Description: Energy management program to } \\
\text { build new energy-efficient commercial } \\
\text { buildings. }\end{array}$ & $\begin{array}{l}\text { Technology: Design features included } \\
\text { increased wall and roof insulation; motion } \\
\text { detectors that turn off lights in unoccupied } \\
\text { rooms; low emissivity window glazing; a } \\
\text { double-entry vestibule to minimize outdoor air } \\
\text { infiltration; energy-saving lighting fixtures; and } \\
\text { lamps and ballasts. Construction costs for the } \\
\text { Dubal-Beck building: } \$ 516,000 \text {. }\end{array}$ \\
\hline $\begin{array}{l}\text { Results: Annual energy costs reduced } 31.5 \% \text {, } \\
(27,800 \mathrm{kWh} / \mathrm{yr})\end{array}$ & Reference: IEA CADDET \\
\hline
\end{tabular}

\begin{tabular}{|c|c|}
\hline $\begin{array}{l}\text { Title: Thin-Walled Hollow Spheres from } \\
\text { Powders }\end{array}$ & Project Type: R\&D \\
\hline Organization: U.S. Department of Energy & Date: N/A, continuing \\
\hline End-use Sector: Commercial building & Affiliated/Future Projects: None \\
\hline $\begin{array}{l}\text { Description: Small, hollow spheres called } \\
\text { aerospheres that are used as thermal insulators } \\
\text { and structural materials. }\end{array}$ & $\begin{array}{l}\text { Technology: Made from alumina, partially } \\
\text { stabilized zirconia, ferrite, and kaolin clay } \\
\text { powder slurries. The uniformity, density, and } \\
\text { quality of the spheres can be controlled during } \\
\text { production. }\end{array}$ \\
\hline $\begin{array}{l}\text { Results: Thermal conductivity was measured as } \\
\text { low as } 0.13 \mathrm{~W} / \mathrm{m}-\mathrm{K} \text {; can be used for insulation } \\
\text { at temperatures }>1500^{\circ} \mathrm{C} \text {. Production costs } \\
\text { could bring costs down to } 50 \notin / \mathrm{b} \text {. }\end{array}$ & $\begin{array}{l}\text { Reference: A Compendium of Energy } \\
\text { Conservation Success Stories } 90\end{array}$ \\
\hline
\end{tabular}




\begin{tabular}{l:l|}
\hline Title: Miami District Cooling Project & Project Type: R\&D \\
\hdashline Organization: U.S. Department of Energy with \\
urns and Roe Company and the Joseph \\
Technology Corporation
\end{tabular}

\begin{tabular}{|c|c|}
\hline $\begin{array}{l}\text { Title: Geothermal Surface Spring Provides } \\
\text { Heating for Colorado Lodge }\end{array}$ & Project Type: Study/demonstration \\
\hline $\begin{array}{l}\text { Organization: Hot Springs Lodge and Pool, } \\
\text { Inc. }\end{array}$ & Date: Completed 1986 \\
\hline End-use Sector: Commercial building & Affiliated/Future Projects: None \\
\hline $\begin{array}{l}\text { Description: To design and implement a } \\
\text { heating and cooling system that would take } \\
\text { advantage of the available low-temperature } \\
\text { geothermal surface spring, reducing energy costs } \\
\text { and saving nonrenewable energy resources. }\end{array}$ & $\begin{array}{l}\text { Technology: A mechanical system designed } \\
\text { for use with low-temperature geothermal surface } \\
\text { spring containing } 51^{\circ} \mathrm{C} \text { water, low-cost heat } \\
\text { exchangers, and copper tubing coils. }\end{array}$ \\
\hline $\begin{array}{l}\text { Results: Saves } \$ 36,500 / y r \text { in energy costs; } \\
50,000 \text { therms nonrenewable energy were saved. }\end{array}$ & Reference: IEA CADDET \\
\hline
\end{tabular}




\begin{tabular}{|c|c|}
\hline Title: Solar-5 & Project Type: Technology transfer \\
\hline Organization: U.S. Department of Energy & Date: N/A \\
\hline $\begin{array}{l}\text { End-use Sector: Residential, commercial } \\
\text { buildings }\end{array}$ & Affiliated/Future Projects: None \\
\hline $\begin{array}{l}\text { Description: Computer program allows } \\
\text { building designers to assess the effect of } \\
\text { different design strategies on energy } \\
\text { performance. }\end{array}$ & $\begin{array}{l}\text { Technology: Solar- } 5 \text { uses a matrix to display } \\
\text { data and provide the results of its energy } \\
\text { analysis. Users can combine up to nine } \\
\text { different schemes into one design and see a } \\
\text { graphic display of the resulting energy flows. }\end{array}$ \\
\hline Results: N/A & $\begin{array}{l}\text { Reference: A Compendium of Energy } \\
\text { Conservation Success Stories } 90\end{array}$ \\
\hline
\end{tabular}

\begin{tabular}{|c|c|}
\hline Title: WINDOW Computer Program & Project Type: Technology transfer \\
\hline Organization: U.S. Department of Energy & Date: N/A \\
\hline $\begin{array}{l}\text { End-use Sector: Residential, commercial } \\
\text { buildings }\end{array}$ & Affiliated/Future Projects: None \\
\hline $\begin{array}{l}\text { Description: WINDOW can determine the } \\
\text { thermal performance of window systems. }\end{array}$ & $\begin{array}{l}\text { Technology: The IBM PC-based series of pro- } \\
\text { grams calculates thermal transmission, shading } \\
\text { coefficients, and surface temperatures of glass. }\end{array}$ \\
\hline $\begin{array}{l}\text { Results: The American Society of Heating, } \\
\text { Refrigerating, and Air-Conditioning Engineers } \\
\text { (ASHRAE) used WINDOW to calculate new } \\
\text { guidelines for window performance. The } \\
\text { program is facilitating work on superwindow } \\
\text { technology. }\end{array}$ & $\begin{array}{l}\text { Reference: A Compendium of Energy } \\
\text { Conservation Success Stories } 90\end{array}$ \\
\hline
\end{tabular}




\begin{tabular}{|c|c|}
\hline $\begin{array}{l}\text { Title: A Simplified Energy Analysis Method } \\
\text { (ASEAM-2) }\end{array}$ & Project Type: Technology transfer \\
\hline Organization: U.S. Department of Energy & Date: N/A \\
\hline $\begin{array}{l}\text { End-use Sector: Residential, commercial } \\
\text { buildings }\end{array}$ & Affiliated/Future Projects: None \\
\hline $\begin{array}{l}\text { Description: ASEAM-2 is nonproprietary and } \\
\text { is used to design heating, ventilating, and air- } \\
\text { conditioning (HVAC) systems in commercial } \\
\text { and residential buildings. }\end{array}$ & $\begin{array}{l}\text { Technology: ASEAM- } 2 \text { can simulate } 13 \\
\text { different types of HVAC distribution systems, } \\
\text { model up to } 10 \text { energy load zones within a } \\
\text { building, and size systems automatically. The } \\
\text { program is modular and can be integrated with } \\
\text { other software programs. }\end{array}$ \\
\hline Results: N/A & $\begin{array}{l}\text { Reference: A Compendium of Energy } \\
\text { Conservation Success Stories } 90\end{array}$ \\
\hline
\end{tabular}

\section{Title: Indoor Air Quality Field Studies Data Base}

Organization: U.S. Department of Energy, the Environmental Protection Agency, Electric Power Research Institute, Gas Research Institute

End-use Sector: Residential, commercial buildings

Description: Data base makes it easier to access information on indoor pollutants and their effect on people.

\section{Project Type: R\&D}

Date: N/A, continuing

\section{Affiliated/Future Projects: None}

Technology: Data base contains field studies of efforts on monitoring concentrations of indoor air pollution concentrations in buildings in the United States and Canada. Information is from more than 300 references. The data base can calibrate, verify, or modify macromodeling efforts designed to predict or characterize indoor pollutant concentrations.

Reference: A Compendium of Energy Conservation Success Stories 90 


\begin{tabular}{|c|c|}
\hline Title: Energy Institutes & Project Type: Education/information \\
\hline Organization: U.S. Department of Energy & Date: 1980 ; continuing \\
\hline $\begin{array}{l}\text { End-use Sector: Residential, commercial } \\
\text { buildings }\end{array}$ & Affiliated/Future Projects: None \\
\hline $\begin{array}{l}\text { Description: Two institutes provide resources } \\
\text { to help university faculty train students to } \\
\text { design energy-efficient buildings. }\end{array}$ & $\begin{array}{l}\text { Technology: The Institutes on Energy and } \\
\text { Engineering Education help engineering faculty } \\
\text { teach students how to design, construct, and } \\
\text { operate energy-efficient buildings. Institute } \\
\text { participants, using case studies, analyze the heat } \\
\text { flow patterns and energy budgets of buildings, } \\
\text { review building plans and equipment data, and } \\
\text { identify alternative energy conservation options. } \\
\text { The Summer Institutes on Energy and Design } \\
\text { help architecture faculty teach students how to } \\
\text { design energy-efficient buildings. Institute } \\
\text { participants attend workshops and take field } \\
\text { trips. }\end{array}$ \\
\hline $\begin{array}{l}\text { Results: The Institutes on Energy and } \\
\text { Engineering Education have held nine four-day } \\
\text { sessions; about } 380 \text { faculty members attended. }\end{array}$ & $\begin{array}{l}\text { Reference: A Compendium of Energy } \\
\text { Conservation Success Stories } 90\end{array}$ \\
\hline
\end{tabular}

Title: City-wide Energy Conservation: Phoenix, Arizona

Organization: U.S. Department of Energy

End-use Sector: Residential, commercial buildings

Description: The city of Phoenix is demonstrating a commitment to energy conservation with a series of U.S. Department of Energy grants.

Project Type: Study/demonstration

Date: 1978; continuing

Affiliated/Future Projects: None

Technology: Individual projects focused on energy savings in the areas of wastewater treatment, water treatment and pumping efficiency, and heating and cooling efficiency in municipal buildings. The city also demonstrated a small-scale cogeneration project that used thermal energy storage and absorption cooling and completed a district cooling assessment.

Results: The grants resulted in more than $\$ 3$ million in energy savings and cost avoidance since 1981.

Reference: A Compendium of Energy Conservation Success Stories 90 


\begin{tabular}{|c|c|}
\hline $\begin{array}{l}\text { Title: Solid-State Ballast for Fluorescent } \\
\text { Lighting }\end{array}$ & Project Type: Study/demonstration \\
\hline Organization: U.S. Department of Energy & Date: N/A \\
\hline $\begin{array}{l}\text { End-use Sector: Residential, commercial } \\
\text { buildings }\end{array}$ & Affiliated/Future Projects: None \\
\hline $\begin{array}{l}\text { Description: Solid-state ballasts improved } \\
\text { performance of fluorescent lamps. }\end{array}$ & $\begin{array}{l}\text { Technology: Solid-state ballasts demonstrated } \\
\text { in office buildings }\end{array}$ \\
\hline $\begin{array}{l}\text { Results: Prototype ballasts improved lighting } \\
\text { efficiency by } 25 \% \text {. More than } 2 \text { million are } \\
\text { being used in U.S. buildings, saving } 200 \text { million } \\
\text { kWh. }\end{array}$ & $\begin{array}{l}\text { Reference: A Compendium of Energy } \\
\text { Conservation Success Stories } 90\end{array}$ \\
\hline
\end{tabular}

\begin{tabular}{|c|c|}
\hline Title: Surface Wave Lamp & Project Type: R\&D \\
\hline Organization: U.S. Department of Energy & Date: 1980 ; continuing \\
\hline $\begin{array}{l}\text { End-use Sector: Residential, commercial } \\
\text { buildings }\end{array}$ & Affiliated/Future Projects: None \\
\hline $\begin{array}{l}\text { Description: Very high (gigahertz) frequencies } \\
\text { concentrate radiation generation close to the } \\
\text { outer walls of a fluorescent lamp and improve } \\
\text { the efficiency of its phosphor in converting } \\
\text { ultraviolet radiation into visible light. }\end{array}$ & Technology: Surface-wave fluorescent lamp \\
\hline $\begin{array}{l}\text { Results: New lamps are } 40 \% \text { more efficient } \\
\text { than conventional fluorescent lamps and promise } \\
\text { a } 50 \% \text { reduction in energy use and }>40,000 \\
\text { hours of lamp life. }\end{array}$ & $\begin{array}{l}\text { Reference: A Compendium of Energy } \\
\text { Conservation Success Stories } 90\end{array}$ \\
\hline
\end{tabular}




\begin{tabular}{|c|c|}
\hline Title: Low-Emissivity Window Coating & Project Type: R\&D \\
\hline Organization: U.S. Department of Energy & Date: Mid-1970s to 1983 \\
\hline $\begin{array}{l}\text { End-use Sector: Residential, commercial } \\
\text { buildings }\end{array}$ & Affiliated/Future Projects: None \\
\hline $\begin{array}{l}\text { Description: Research on low-E coatings } \\
\text { include computer simulation of alternative } \\
\text { window designs, creation of coating test } \\
\text { facilities, and technology transfer programs to } \\
\text { disseminate results. }\end{array}$ & Technology: Low-emissivity window coatings \\
\hline $\begin{array}{l}\text { Results: Low-E coatings reduce window heat } \\
\text { loss. Research stimulated glass and window } \\
\text { industries to invest in technology. It is } \\
\text { anticipated that } 50 \% \text { of all residential window } \\
\text { sales will be low-E windows by } 1992 \text {. }\end{array}$ & $\begin{array}{l}\text { Reference: A Compendium of Energy } \\
\text { Conservation Success Stories } 90\end{array}$ \\
\hline
\end{tabular}

Title: Measurement Device for Thermal Resistance of Insulation

Organization: U.S. Department of Energy

End-use Sector: Residential, commercial buildings

Description: A 1-meter line-source guarded hot plate accurately measures thermal resistance of insulation up to 15 -inches thick.

Results: Accurate heat-transfer measurement eliminates overinsulation, saving consumers $\$ 90$ million annually.
Project Type: R\&D

Date: 1979, N/A

Affiliated/Future Projects: None

Technology: The hot-plate measuring device

Reference: A Compendium of Energy Conservation Success Stories 90

Project Type: Study/demonstration

Date: N/A

Affiliated/Future Projects: None

End-use Sector: Residential, commercial buildings

Description: Research, demonstrations, and feasibility assessments were done in more than 50 communities to redevelop district heating and cooling systems.

Results: The program currently yields energy savings of 5 trillion Btus ( 5.2 trillion joules) annually in the United States and is being adopted by several U.S. cities.
Technology: N/A

Reference: A Compendium of Energy

Conservation Success Stories 90 


\begin{tabular}{|c|c|}
\hline $\begin{array}{l}\text { Title: District Heating and Cooling } \\
\text { Development: Kent County, Michigan }\end{array}$ & Project Type: Study/demonstration \\
\hline $\begin{array}{l}\text { Organization: U.S. Department of Energy, } \\
\text { Kent County, Michigan }\end{array}$ & Date: 1986; continuing \\
\hline $\begin{array}{l}\text { End-use Sector: Residential, commercial } \\
\text { buildings }\end{array}$ & Affiliated/Future Projects: None \\
\hline $\begin{array}{l}\text { Description: A waste-to-energy cogeneration } \\
\text { facility serves } 320,000 \text { people in six } \\
\text { communities. }\end{array}$ & $\begin{array}{l}\text { Technology: State-of-the-art pollution-control } \\
\text { equipment. }\end{array}$ \\
\hline $\begin{array}{l}\text { Results: The facility processes } 625 \text { tons of } \\
\text { waste daily, delivers about } 115,000 \mathrm{lb} \\
(52,155 \mathrm{~kg} \text { ) of steam hourly, and generates } \\
14 \mathrm{MW} \text { of electricity. Tipping fees estimated at } \\
\$ 38 \text { per ton increase the county's revenues. }\end{array}$ & $\begin{array}{l}\text { Reference: A Compendium of Energy } \\
\text { Conservation Success Stories } 90\end{array}$ \\
\hline
\end{tabular}

\begin{tabular}{|c|c|}
\hline Title: Acoustic Leak Detection System & Project Type: R\&D \\
\hline $\begin{array}{l}\text { Organization: U.S. Department of Energy, } \\
\text { Consolidated Edison, Fluid Conservation } \\
\text { Systems Corporation }\end{array}$ & Date: N/A \\
\hline $\begin{array}{l}\text { End-use Sector: Residential, commercial } \\
\text { buildings }\end{array}$ & Affiliated/Future Projects: None \\
\hline $\begin{array}{l}\text { Description: A computer-based acoustic } \\
\text { monitoring system can accurately locate } \\
\text { underground pipe leaks. }\end{array}$ & $\begin{array}{l}\text { Technology: Data fed into a computer provide } \\
\text { information on location, size, and type of leak. }\end{array}$ \\
\hline $\begin{array}{l}\text { Results: Water leaks can be detected from } \\
500 \text { feet ( } 152 \text { meters) away and escaping steam } \\
\text { from } 1500 \text { feet ( } 457 \text { meters) away. The detector } \\
\text { system could save utilities thousands of dollars } \\
\text { weekly. }\end{array}$ & $\begin{array}{l}\text { Reference: A Compendium of Energy } \\
\text { Conservation Success Stories } 90\end{array}$ \\
\hline
\end{tabular}




\begin{tabular}{|c|c|}
\hline Title: Infiltration Model & Project Type: R\&D \\
\hline Organization: U.S. Department of Energy & Date: 1980 ; continuing \\
\hline $\begin{array}{l}\text { End-use Sector: Residential, commercial } \\
\text { buildings }\end{array}$ & Affiliated/Future Projects: None \\
\hline $\begin{array}{l}\text { Description: An infiltration model provides } \\
\text { simple techniques for estimating infiltration } \\
\text { rates in residential buildings. }\end{array}$ & $\begin{array}{l}\text { Technology: The model uses leakage } \\
\text { properties of the building envelope and site } \\
\text { weather data to predict performance of air } \\
\text { infiltration in the building shell. }\end{array}$ \\
\hline $\begin{array}{l}\text { Results: The model, accurate to within } 20 \% \text {, is } \\
\text { used by building designers and is incorporated } \\
\text { into major energy-performance computer } \\
\text { programs. Residential designs using the model } \\
\text { are typically } 10 \% \text { to } 15 \% \text { more energy efficient. } \\
\text { The model is being extended to analyze } \\
\text { infiltration in commercial buildings. }\end{array}$ & $\begin{array}{l}\text { Reference: A Compendium of Energy } \\
\text { Conservation Success Stories } 90\end{array}$ \\
\hline
\end{tabular}

\begin{tabular}{|l:l|}
\hline Title: DOE-2 & Project Type: Technology transfer \\
\hdashline Organization: U.S. Department of Energy & Date: 1977 ; continuing \\
\hdashline $\begin{array}{l}\text { End-use Sector: Residential, commercial } \\
\text { buildings }\end{array}$ & Affiliated/Future Projects: None \\
\hdashline $\begin{array}{l}\text { Description: DOE-2 is a building energy } \\
\text { simulation program for designing buildings and }\end{array}$ & Technology: DOE-2 works on personal and \\
evaluating their energy use, efficiency, comfort, \\
and cost.
\end{tabular}




\section{Note on the FINESSE Project}

The FINESSE Project (Financing of Energy Services for Small-scale Energy Users) was begun in 1989 by the U.S. Department of Energy's Committee on Renewable Energy, Commerce, and Trade (CORECT) in cooperation with the World Bank. It was founded on the notion that traditional energy sector lending for large-scale coal and hydropower faced increasing obstacles. Moreover, the largescale program did not meet the needs of households, cottage industries, and other enterprises in the developing world.

Alternative energy technologies-energy efficiency and renewable energy-offer a choice that matches the scale of the need. National energy planning and international financing tend not to incorporate these technologies, however.

FINESSE offers replicable models for financing and institutionalizing alternative energy services. These models are based on channeling donor funds through a range of utility, private sector, nongovernmental, and commercial intermediaries.

The FINESSE Project encompasses several key activities:

- $\quad$ Conducting ASEAN country market studies

- Initiating efforts to promote the upstream manufacture of energy-efficient light bulbs and appliances

- Examining the institutional environment for setting up and operating alternative energy projects

- Identifying ASEAN project opportunities and financial strategies

- Establishing an international forum assembling key members of the development and financial community.

In October 1991, a FINESSE workshop was held in Kuala Lumpur, Malaysia. The purpose of the workshop was to address institutional, policy, and educational barriers hindering alternative energy (energy efficiency and renewable energy) deployment in developing countries and to offer replicable financial models for project implementation. The workshop targeted Indonesia, Malaysia, the Philippines, and Thailand. More than 200 delegates attended.

Three main conclusions emerged from the workshop.

1. Developing countries are taking an aggressive role in planning their own energy futures and are reducing their dependence on outside advisors. They are increasingly recognizing that renewable energy and energy-efficient technologies can contribute to the energy mix of their countries.

2. FINESSE offers the World Bank, the Asian Development Bank, bilaterals, and other donors replicable strategies for financing small-scale energy projects. These strategies rely on existing in-country intermediary organizations to channel donor funds to individual consumers. 
3. It was demonstrated that significant investment opportunities exist for alternatives that meet the test of financial and economic viability. Approximately $\$ 825$ million in bankable alternative energy project opportunities were identified by Malaysia, the Philippines, Thailand, and Indonesia.

A number of activities, under way at the time of the workshop, gathered momentum as a result of the event:

- Establishing a FINESSE unit at the World Bank, with secure financing

- Obtaining host country commitment to FINESSE

- Conducting project appraisal/preparation

- $\quad$ Expanding FINESSE to other Asian countries and regions.

The following are sponsors of the project:

- The World Bank

- U. S. Department of Energy

- Netherlands Ministry of Foreign Affairs

- United Nations Development Programme

- Asian Development Bank

- U. S. Agency for International Development

- U. S. Environmental Protection Agency

- Asian and Pacific Development Centre. 